
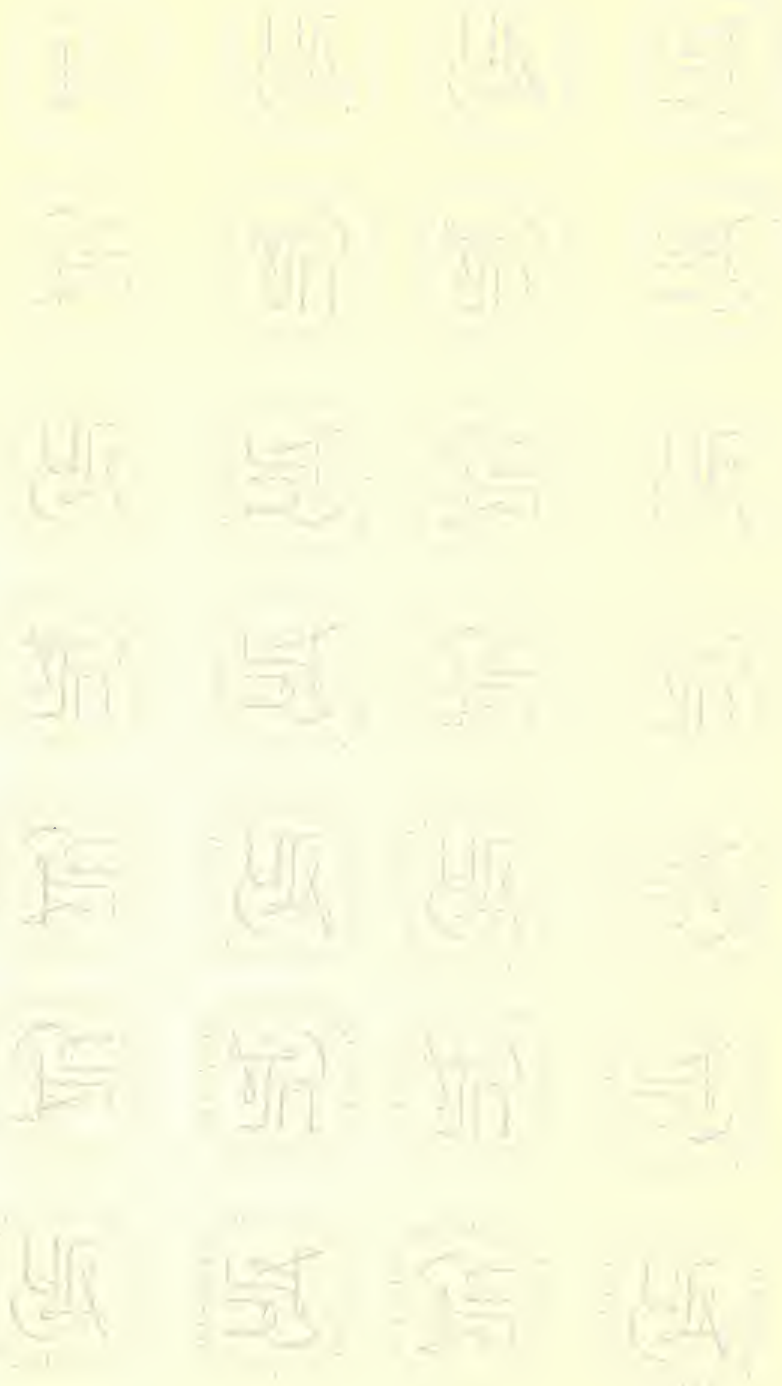

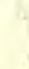


W a 47 to 7 sodat [enuur 47uaa71t47 a47 


\section{The Yucceae.}

\section{BY WILLIAM TRELEASE.}

(FroM THE THIRTEENTH ANNUAL REPORT OF THE MISSOURI BOTANICAL GARDEN.)

Issued July 30, 1902.

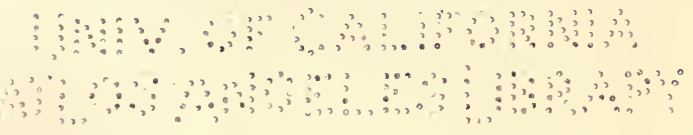




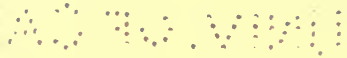

$$
\begin{aligned}
& \vdots \cdots: \vdots \because \vdots \vdots \vdots \vdots \vdots \vdots \cdots
\end{aligned}
$$




\section{QK \\ 495 \\ 472 T $7 y$}

\section{THE YUCCEAE。*}

BY WHLLAM TRELEASE.

\section{INTRODUCTION.}

The large family Liliaceae has been subjected to very different treatment by the writers who at various times have monographed it or attempted to indicate a natural i s sequence for its genera. The tribes Aloineae and Yuccoideae, respectively African and American, were treated together by Mr. Baker $\dagger$ with the implied recognition of close affinity, the principal synoptic differences between them consisting in the succulent leaves and gamophyllous perianth of the former, and the less succulent more fibrous leaves and distinct perianth segments of the latter, in which he includes Yucca, Hesperaloe, Herreria, Beaucarnea, and Dasylirion. $\ddagger$

Bentham and Hooker § also place the aloids and yuccoids close together, characterizing the tribe Dracaeneae, in which the latter are included, by its mostly distinct perianth segments, If and including in it Hesperocallis, Hesperaloe, Yucca, Nolina (Beaucarnea), and Dasylirion, of the New

* Presented in abstract, with lantern lllustrations, before the BotanIcal Society of America, at its New York meeting, June 28, 1900, and before the Academy of Science of St. Louis, Feb. 3, 1902.

+ Journ. Linn. Soc. Bot. 18 : 148. (1881).

$\ddagger$ 1. c. 152 .

$\S$ Genera Plantarum. 3 : 750, 777. (1883).

I The generic descriptions show that the segments are connate into a tube in Hesperocallis, Dracaena, Cordyline, Milligania, and some species of Astelia, and barely united at the base in Yucca.-1. c. 778. 
World, and Dracaena, Cordyline, Astelia and Milligania, of the Old World, while the South American Herreria is removed to another tribe.

Professor Engler, ${ }^{*}$ who treats the Aloineae as pertaining to a group placed at a eonsiderable distance from the Dracaenoideae, includes in the latter the Old World Dracaeneas, of the genera Colnia, Cordyline, Astelia, and Milligania, with perianth segments eonnate at base, and the New World groups Nolineae, of the genera Notina and Dasylirion, and Yucceae, of Yucca and Hesperaloe, with the segments distinet. removed to another group.

The present paper deals only with this group Yucceae of Engler, and includes the principal conelusions reached in an intermittent herbarium, garden and field study extending over the last sixteen years, in the course of which nearly all of the spontaneous speeies have been examined and photographed in their native homes and many of them introduced or reintrodueed into eultivation in this country and Europe from definitely located sources.

In its alliance, the group Yucceae is characterized by the possession of similar subequal withering-persistent petaloid perianth segments, a 3-eelled ovary with more or less intruded dorsal false septa, many ovules 2 -ranked in each cell, a subterete elongated embryo obliquely placed across the seed, and germination with arehed cotyledon. $\ddagger$

* Natürl. Pflanzenfamilien. II Teil. 5 Abteil. 19, 70. (1888).

$\dagger$ It is to be observed that, with most writers, Engler speaks of the segments as free or somewhat united at base, in his generic description of Yucca.-1. c. 70 .

I In all of the genera of this group, in germination the cotyledon assumes an arched form, with the seed remnant on or in the soil (from which it is ultimately raised in some cases), instead of directly carrying this up ou its end as it commonly does in Liliaceae. - See The Garden. 8: 300. f. - Gard. Chron. n. s. 24: 216. - Lubbock, Contr. Knowl. of Seedlings. 2 : 578, 613. - Copeland, Bot. Gaz. 31 : 419. f. 3. 


\section{REVISION OF THE YUCCEAE.}

The genera constituting the group appear to admit of most natural limitation as follows :-

Flowers oblong or narrowly campanulate, scarcely $15 \mathrm{~mm}$. wide, rosyred or greenlsh: fllaments shortly adnate to the petals below, slender, erect, inflexed at apex; anthers oblong: style flliform, minutely papillate about the scarcely enlarged stigma. Hesperaloe. Flowers globose or broadly campanulate, spreading to a width of 50 to $100 \mathrm{~mm}$., white or creamy, often tinged with green, bronze or violet: filaments clavately enlarged; anthers shortly sagittate.

Style filiform, abrupt; stigma capitate, long-papillate: fllaments adnate to the petals below, erect.

Hesperoyucca.

Style stout or wanting, gradually if at all narrowed; stigma openly perforate, not papillate, more or less deeply 6-notched: fllaments mostly outcurved at apex.

Perianth polyphyllous, or the segments barely connate at base, to which the fllaments are slightly attached.

Segments of perianth thick, mostly inflexed: style wanting: nectar glands in walls of ovary small. Clistoyucca.

Segments thin and petaloid, spreading at night: style evident: nectar glands large but mostly inactive. Yucca.

Perianth gamophyllous and tubular below, the stamens inserted in its throat, otherwise as in Yucca.

Samuela.

\section{HESPERALOE Engelmann.}

Perianth oblong or narrowly campanulate, of subequal closely applied distinct oblong succulent segments outcurved at tip. Filaments adnate to base of perianth, slender, erect, inflexed at apex; anthers oblong, introrse. Ovary ovoid, shorter than the long slender style; stigma not enlarged, minutely papillate and perforate. Fruit capsular, globose-oblong, rugose-veiny, 3-celled, 6valved at least above, the valves with short solid erect. beak. Seeds thin, flat: albumen not ruminated. Subacaulescent plants with filiferous-margined long concave striate scarcely pungent smooth leaves, and loosely panicled few-branched inflorescence.

SYNOPSIS OF SPECIES.

Flowers rosy-red or salmon-colored.

H. parviflora.

Flowers green, tinged with purple.

H. funifera. 


\section{H. PARvifloka (Torrey) Coulter, Contr. U. S. Natl. Herb. 2 : 436. (1894.)}

H. yuccaefolia Engelmann, Bot. King. 497. (1871). Trans. Acad. St. Louis. 3 : 55. - Baker, Gard. Chron. 1871 : 1516. Journ. Linn. Soc. Bot. 18 : 231. - Watson, Proc. Amer. Acad. $14: 250$.

Yucca (?) parviflora Torrey, Bot. Bound. 221. (1859). - Baker, Gard.

Chron. $1870: 923$.

Y. paviflora Hemsley, Garden. 8 : 132 .

Aloe yuccaefolia Gray, Proc. Amer. Acad. 7 :390. (1867). Gard. Chron. 1870 : 1092 .

Usually cespitosely suckering. Leaves arcuately spreading, 1 to 1.25 $\mathrm{m}$. long, something over $25 \mathrm{~mm}$. wide, striate-ridged on the back. Inflorescence 1 to $1.25 \mathrm{~m}$. high, the few branches divaricate, glabrous and subglaucous. Flowers fascicled above the bracts, on soft articulated rosy pedicels, ephemeral, rosy, tubular, mostly about $35 \mathrm{~mm}$. long; style long-exserted. Capsule something over $25 \mathrm{~mm}$. long; seeds $5 \times 8$ mm. - Plate 1, f. 1.

Southwestern Texas; between the Rio Grande and the southern part of Valverde County, Kinney County, and the western part of Zavalla County. - Plate 84, f. 1 .

One of the puzzling plants brought in by the naturalists of the United States and Mexican Boundary Survey, collected between the mouth of the Pecos and the Nueces, was described by Dr. Torrey* under the name Yucca? parviflora, the description of the filiferous Yucca-like leaves and of the inflorescence being good, but that of the flowers and fruit indifferent, - the perianth noted as "white?", and the unripe fruit as " doubtless fleshy."

In his enumeration of the known forms of Yucca in 1870 , Mr. Baker, referring to dried specimens in the Kew herbarium, as well as to the original description, characterizes the plant in much the same way, but observes that the flower is more like that of an Ornithogalum of the Pyrenaicum group than that of its neighbors of the genus $Y u c c a$. Mention is also made of the peculiarity of the flowers in an article on Yucca by Mr. Hensley, who, evidently through a typographieal error, calls the species $Y$. paviflora.

* Emory, Rept. U. S. \& Mex. Bound. Surv. 2. Botany of the Boundary by John Torrey. 122. - Referred to in this paper as "Bot. Bound." 
Before these articles by Baker and Hemsley were published, living specimens had been sent to Dr. Gray, and an examination of flowers which these bore in the Harvard Botanical Garden showed the generic distinctness of the plant from Yucca, and so strong a resemblance to the true Aloes of Africa that Dr. Gray did not hesitate to transfer it to the genus Aloe, under the new and descriptive specific name yuccaefolia. The redescription shows that the flowers are pale red and the fruit capsular.

Recognizing sufficient differences between this American Yucca-leaved and Yucca-fruited Aloe and the African plants properly representative of that genus, Dr. Engelmann * created for it the genus Hesperaloe, in 1871, noting that the leaves, pollen and seeds are those of $Y$ ucca, the perigone and pistil are those of Aloe, and the filaments, adnate at base and geniculate upwards, resemble those of Agave. This description was repeated by Mr. Baker the same year, the specific name yuccaefolia, introduced by Dr. Gray, being employed in both instances.

The original specific name proposed by Dr. Torrey was restored, in combination with the generic name Hesperaloe, by Professor Coulter in his account of the botany of western Texas, in 1894.

Notwithstanding its beauty and unusual characters, little is known of this plant in its typical form, aside from the original observations of Torrey, Gray, Baker and Engelmann. The only herbarium specimens that I know of were collected by Wright: - in June, 1849, between the Nueces river and Elm creek and on the banks of the latter; apparently in the autumn of the same year, on hills of Devil's river; and May 15, 1851, between the Leona and Nueces. $\dagger$

\footnotetext{
* King, Rept. U. S. Geol. Explor. Fortieth Parallel. 5. Botany, by Sereno Watson. 497. - Referred to here as "Bot. King."

† For the localities represented by specimens contained in the Gray herbarium, I am indebted to Miss Mary A. Day.
} 
In April, 1900, while passing a day in San Antonio, Texas, I observed a Hesperaloe planted in one of the plazas of that city, which in its long arehing concave filiferous leaves, oblong Aloe-red flowers with white styles protruding for a distance equal to one-third or one-half the length of the perianth, and very short anthers, agreed with the description and seanty available herbarium material of II. yuccae folia, and from this plant, offsets of which are now growing in the Missouri Botanical Garden, the following notes have been made.

The flowers are ephemeral, and their original appearance would scarcely be guessed from the withered remains after they have fallen, or from such herbarium material as is usually seen. Though the buds are erect, the soft, rosy articulated pedicels ultimately arch over, so that the expanded flowers are horizontal or more frequently pendent. In texture they are suggestive of Lapageria, and this resemblance, notwithstanding their smaller size and somewhat different form, is increased by their beautiful outward shading with rose-color, on a creamy ground color which prevails on the inner surface. The firm succulent distinct but closely appressed segments of the perianth are about half a millimeter thick in the middle and outwardly recurved near the end, which, as in Yucca, is tipped with a minute tuft of white hairlike papillae. The inner segments are 8 or $9 \mathrm{~mm}$. wide, and the outer segments a little narrower. The white or rosy slightly tapering filaments are adnate to the segments for a short distance and then stand erect, with the very slender apex abruptly incurved so as to make the oblong versatile anthers suberect and introrse, close against the filaments, with their abundant bright yellow powdery pollen exposed toward the style. The conicalovoid greenish ovary is very slightly 6-grooved, and the white style, somewhat tapering and triquetrous near the base, soon becomes filiform and terete except for three 
faint grooves which persist to the very inconspicuously 3-lobed perforate somewhat fimbriate stigma. The ovary possesses three large plane septal nectar glands, passing outward at top into conducting grooves which open at the base of the pistil, and the abundant secretion of which, when not removed, drips to the mouth of the pendent flower so that toward the end of the day, when the flower closes, the anthers, style and perianth are gummed together into a nearly inseparable mass. The ovules resemble in shape and arrangement those of the capsular species of $Y u c c a$, and the erect capsule and thin flat black seeds are equally suggestive of this section of Yucca.

\section{H. parviflora Engelmanni (Krauskopf) Trelease.}

H. Engelmanni Krauskopf, Notice to Botanists, etc., Ang. 1878 [circular]. - Watson, Proc. Amer. Acad. 14:250. (1879). - Baker, Journ. Linn. Soc. Bot. 18 : 231. - Coulter, Contr. U. S. Natl. Herb. 2 : 436 .

H. yuccaefolia Garden. 18 : 188. 20 : 71, 361. 21 : 324. - Gard. Chron. n. s. 18 : 87, 109, 199. f. 34. - Andr6, Rev. Hort. 58 : 64. - Hooker, Bot. Mag. iii. 56. $p l .7223$.

Flowers oblong-campanulate, about $25 \mathrm{~mm}$. long; styles scarcely exceeding the perianth. - Plates $1, f .2$. 2 .

Southwestern Texas, about the head of the west fork of the Nueces river.

In 1878, Mr. E. Krauskopf, of Fredericksburg, Texas, issued an advertising circular mentioning $H$. yuccaefolia and offering for sale plants of a Hesperaloe which he had brought from the western dry branch of the Nueces river and for which he proposed the name H. Engelmanni. The flowers are described as bell-shaped, red, with short thick style and anthers as much ss a quarter of an inch long, whereas in $H$. yuccaefolic the latter are said to be several times shorter than the filiform style. Specimens of this supposed second species were sent to Dr. Engelmann, through Lindheimer, and are noted in his herbarium as having been collected by Meusebach, though they are evidently of the collection referred to by Krauskopf. 
Some time after this, John Saul, of Washington, sent flowers of IIesperaloe, from the Nueces river, to the editor of The Garden, under the name of $H$. yuccaefolia, ${ }^{*}$ and at about this time the genus seems to have gone into one or more English gardens, probably from this source. $\dagger$ The same form apparently was again introduced into England in 1888, $\ddagger$ but I have not learned from what source.

Dr. Watson, in his revision of the North American Liliaceae, shortly after the discovery of $I I$. Engelmanni, mentions this proposed species as from the same region as 11. yuccaefolia, but imperfectly known, though perhaps to be distinguished by the more slender and flexuous branches of its inflorescence, smaller bracts, twice longer anthers, and stouter included style scarcely longer than the ovary. A similar equivocal mention was made in 1880 by Mr. Baker, of H. Engelmanni, which is ignored by Professor Engler, $\S$ but distinctly recognized by Professor Coulter in his Botany of western Texas, in connection with the earlier species.

So far as the evidence goes, all of the Hesperaloe cultivated in Europe, and to which reference has been made above, belongs to this second form, and may perhaps have been derived from Krauskopf's original collection.

In May, 1900, a plant procured some three years before from Mr. P.J. Berekmans, I and itself possibly derived from Krauskopf, originally, came into bloom at the Missouri

* Garden. 18: 188. From the phraseology of a quotation from Mr. Sanl, it may be inferred, perhaps, that the plant bearing these flowers was derived originally from Krauskopf.

† See The Garden. 20: 71, 361. 21: 324, where a plant is said to have been in continuous bloom from July 1881 until May 1882, with promise of continuing to flower for another month or two. - Gard. Chron. n. s. $18: 87,109,199$. f. 34 .

† Curtis's Bot. Mag. iii. 56. pl. 7223.

§ Engler \& Prantl. 1. c. 71.

I See Berckmans, Gard. Monthly. 1883 : 323. - Wiener Ill. Gart.Zeit. 11 : 268. 
Botanical Garden, and continued to flower until well into the fall. The first flowers which opened, though shorter than those of the San Antonio plant referred to H. parviflora, and consequently broader relatively to their length, possessed the conspicuously exserted white style and short anthers (scarcely over $2 \mathrm{~mm}$. long) of that species. After the first few flowers, those which opened were relatively much broader, because of a considerable actual shortening, so that the expression bell-shaped, which has been used for H. Engelmanni, might be applied to them, and the style was not exserted, merely reaching to the mouth of the perianth, and, in fact, was slightly shorter than the stamens. Except for having their anthers a very little shorter, these flowers are the counterpart of a well-preserved specimen of the original of $H$. Engelmanni sent to Dr. Engelmann by Lindheimer in 1878, though the included style of the latter is a little longer than the stamens. Still later flowers of the same plant, while preserving the short broad form, again had the style a little exserted (Plate 2 ).

As in typical $H$. parviflora, the leaves, which are deeply concave and with free marginal fibers, differ in width, as indeed, is usual in the genus $Y u c c a$, and the inflorescence, which in vigorous plants has a few spreading branches, may sometimes be simple, in either case the fascicled flowers continuing to develop in succession for many months, and varying from deep rosy-red, when well lighted, to a salmon-color, when shaded from strong light.

For the present, this short-flowered plant, with the style included or very slightly exserted, and which seems to come from a point a little north of but very close to the known range of $H$. parviflora, appears to be varietally separable from the latter in these characters, and should bear the name Engelmanni given to it as a specific name by Krauskopf. 


\section{H. funifera (Koeh) Trelease.}

II. Davyi Baker, Kew Bull. 1899 : 226.

H. Engelmanni Baillon, Hist. des Pl. 12 : 511 . - Urbina, Cat. Pl. Mex. 352 .

Yucea funifera Koch, Belg. Hort. 12:132. (1862). - Lemaire, Ill.

Hort. 13: 99. (1866), - Baker, Journ. Linn. Soc. Bot. 18 : 228.

Agave funifera Lemaire, Ill. Hort. 11 : Misc. 65. [66a]. (1864).

Often cespitose. Leaves larger, at length less concave, often with much coarser marginal fibers. Inflorescence 2 to $2.5 \mathrm{~m}$. high, few branched near the top. Pedicels and flowers purplish green, glancons, the latter about $25 \mathrm{~mm}$. long; style scarcely exserted. Capsule 25 to 50 $\mathrm{mm}$. long, with strong beak, the false septum evanescent or protruding into the cell only toward the base, where it forms a large thin tooth; seeds $6 \times 9 \mathrm{~mm}$. - Plates $3.4, f .1 .81, f .8$.

Northern Mexico, between the Rio Grande and the Sabinas, and, apparently, in the state of San Luis Potosi (Pringle, 3911). - Plate 92, f. 1.

The Engelmann herbarium contains a fruiting fragment, at first referred to Yucca but afterward to Hesperaloe, collected in 1847 by Dr. Wislizenus at Cerralvo, northeast of Monterey. Similar capsules were brought by Dr. Parry, in 1878, from " the plains between Monterey and the Rio Grande.' The herbarium of the Field Columbian Museum contains excellent specimens of the same plant from Bustemente, in the State of Nuevo Leon, collected by Henry W. Wood in July, 1900. In 1891, Mr. Pringle made good leaf and fruit specimens, representing the same genus, at the Hacienda de Angostura, east of San Luis Potosi, which were distributed as $H$. Engelmanni, under the number 3911, and so referred to by Baillon.

In March, 1900, when going over the Mexican International railroad, north of the Sabinas river, I observed a considerable quantity of what was evidently a Hesperaloe, with persisting capsules of the preceding year, which came down to the railroad only on the higher ridges through which cuts had been made. Toward the end of April, when the plants had begun to bloom, I visited this region again, and some six kilometers south of Peyotes collected 
herbarium specimens and viable seeds of the plant. This Hesperaloe appears to be the same as the herbarium material referred to, though neither foliage nor flowers accompany the capsules first collected, and the few flowers distributed by Mr. Pringle from further south are not in very satisfactory condition while the marginal threads, which are slender in the many plants seen by me, are very thick, triquetrous, wavy and rigid on his leaves.

This species, the at first very concave leaves of which may be as much as $40 \mathrm{~mm}$. wide and nearly $2 \mathrm{~m}$. long, finely striate-grooved on the back and with long conspicuous marginal fibers, as in the other representatives of the genus, produces a divaricately few-branched, tall panicle, on which, fascicled in the axils of the bracts, are borne the oblong ephemeral flowers. Unlike those of H. parviflora and its variety Engelmanni, both of which have pedicels and flowers ranging from a creamy tint through salmon-color to typically a beautiful shade of red suggestive of Aloe and Gasteria, the flowers and short pedicels of this species are noted by Mr. Pringle as being " purplish, shading to whitish," and in the plants observed about Peyotes were of a dingy purplish green and decidedly glaucous, the spreading flowers being about $25 \mathrm{~mm}$. long, with stamens and style included and of about equal length, and the anthers 5 to $7 \mathrm{~mm}$. long. The globose to broadly oblong solid-beaked capsules are strongly transversely reticulate-veined, and the thin black seeds are like those of the other species.

In 1898 Mr. Baker described, under the specific name Davyi, a green-flowered Hesperaloe from "California?" which had been sent him by Mr. J. Burt Davy from the garden of the University of California at Berkeley. Mr. Davy tells me that no record is found of the source of the seeds from which this was grown. Dr. F. Franceschi, of Santa Barbara, California, states that two original plants were raised, one of which flowered in 1898, yielding the 
material on which Mr. Baker's description was based, while the other was secured by Dr. Franeeschi, who has since sent vigorous suckers from it to Kew and to the Missouri Botanical Garden, these suckers having formed after the plant bloomed. It is not improbable that the seeds from which these plants were raised were derived from Mr. Pringle's collection of 1891, and the living plant which I have examined shows, as would hardly have been expected from Mr. Baker's description, leaves at first as concave as those of the other species of Hesperaloe, and quite indistinguishable from those of the plants seen below Peyotes, so that it seems safe to refer all of these specimens of the Mexican table land to $H$. Davyi, which appears therefore to be rather widely distributed and which differs markedly from the Texan forms in the color of its flowers.

Many years ago the Tonels introduced into European gardens a plant which seems never to have flowered there, and which was mentioned a number of times under the garden name Yucca funifera. No Yucca is yet known which possesses channeled filiferous dorsally striate leaves comparable to those of $Y$. funifera as described, and though its apparent complete disappearance from cultivation makes its identity a matter of conjecture only, the foliage description so well fits this Mexican species of Hesperaloe as to leave little doubt in my mind that the latter should bear the name H. funifera.

\section{HESPEROYUCCA (Engelmann) Baker.}

Perianth broadly campanulate, of subequal distinct thin broadly lanceolate concave segments. Filaments evidently adnate to perianth below, clavate, suberect; anthers didymously cordate. Ovary oblong-ovoid or obovoid, mostly longer than the short slender style; stigma capitate, longpapillate, minutely perforate. Fruit capsular, incompletely 6-celled, 3-valved through the laciniate false scpta. Seeds 
thin, flat; albumen not ruminated. - Subacaulescent plants with straight needle-pointed rough-margined flat leaves, and ample panicle.

H. Whipplei (Torrey) Baker, Kew Bull. 1892 : 8. — Trelease, Rept. Mo. Bot. Gard. 4 : 208. pl. 16, 23.

Yucca Whipplei Torrey, Bot. Bound. 222. (1859). - Baker, Gard. Chron. 1870: 828 . $1871: 1516$. n. s. 6: 196. f. 42. n. s. $23: 796$. Journ. Linn. Soc. Bot. 18 : 230. - Palmer, Amer. Journ. Pharm. 50 : 587. - Garden. 27 : 266. 35 : 561. f. - Engelmann, Bot. King. 497. Trans. Acad. St. Louis. 3 : 54, 214, 372. - Watson, Proc. Amer. Acad. 14: 254. Bot. Calif. 2 : 164. - Andre, Rev. Hort. 58 : 67. f. 13. - Smith, Gard. Chron. ill. 13 : 749. - Coville, Contr. U. S. Natl. Herb. 4: 203. - Merriam, N. Amer. Fauna. 7: 359. - Trelease, Rept. Mo. Bot. Gard. 3 : 164. pl. 11, 12, 54.- Gard. \& For. 8 : 414-5. f. - Hooker, Bot. Mag. 111. 55. pl. 7662. - Land of Sunshine. 11: 251. f. - Orcutt, West Amer. Sclentist. 6 : 134.

Y. Whipplei glauca Wlener Ill. Gart.-Zeit. 14 : 197.

Y. Whipplei graminifolia Baker, Journ. Linn. Soc. Bot. 18 : 230.

Y. aloifolia Torrey, Pac. R. R. Rept. 4 : 147.

$Y$. filamentosa Home and Flowers. $11^{2}: 12$. $f$.

Y. graminifolia Wood, Proc. Phil. Acad. 1868 : 167.

$Y$. Ortgiesiana Roezl, Belg. Hort. 1880 : 51.

Y. Engelmanni Gard. Chron. n. s. $14: 43$. (1880).

? Y. Californica Groenland, Rev. Hort. 1858: 434. - Lemaire, IIl.

Hort. 10: after pl. 372. (1863). 13: 96. - Gard. Chron. n. s. $5: 794,829$.

Simple or, in the mountalns, frequently cespitose. Leaves ascending, rigid, .3 to $1 \mathrm{~m}$. long, about $15 \mathrm{~mm}$. wide, plano-convex, subtriquetrous, or keeled on both faces, sometimes falcate, striate, glaucous, keenly but finely denticulate, with very slender pungent end spine. Inflorescence 2 to $5 \mathrm{~m}$. high, oblong, long peduncled, glabrous. Flowers $\mathbf{Y u c c a}$-like, pendent, fragrant. Capsule about $5 \mathrm{~cm}$. long: seeds 6 to $7 \times 8 \mathrm{~mm}$. Plates 4, f. 2. 5. 81, f. 9.

California, from the mountains above Monterey to the vicinity of Alamo, lower California ; eastward to the vicinity of San Bernardino - Plate 84, f. 1.

Yucca Whipplei is the name proposed by Dr. Torrey, and still commonly employed, for a plant which, when in bloom, forms one of the most striking and beautiful features of the Coast-range vegetation of southern California. 
From all other Yuccas it differs in the slender style rising abruptly from the top of the ovary and capitately enlarged into a papillate stigma, and in possessing somewhat glutinous pollen, as well as in certain capsular characters, which led Dr. Engelmann * to give it the sectional name Hesperoyucca, which both Mr. Baker and the writer have proposed to employ as a generic name.

Though the mountain and valley forms vary greatly in amplitude of panicle, etc., only one species of Hesperoyucca appears capable of characterization, and this has long been in cultivation in European gardens, partly under the name Yucca Whipplei and partly under the name $Y$. Californica, which has further been applied to very diverse things. If it were certain that the brief foliage description given by Groenland in 1858 really refers to this plant, the specific name Californica has a slight priority over the name Whipplei, which though written in 1858 was not published until the following year, but the propriety of this substitution of name is open to considerable question.

$Y$.graminifolia $†$ Wood, from the vicinity of Los Angeles, though the leaves are described as more flaccid, can hardly refer to other than the typical form, which to the north of Los Angeles becomes very large, and the name is not therefore applicable to the plant that is abundant about San Bernardino, e. g. at Arrowhead Springs and in the Cajon pass, as $I$ at one time thought might be the case. $\ddagger$ This latter plant very frequently has the flowers shaded with purple or violet, and it was to one of the most pronounced of these tinted formsthat M. André in 1884 applied the name $Y$. Whipplei violacea, $\S$ though the name stands for too inconstant a character to have more than horticultural value.

* Bot. King. 497. (1871).

† This name had been applied, in 1837, to the plant subsequently named Dasylirion graminifolium.

† Rept. Mo. Bot. Gard. 4: 215. pl. 17, 23.

$\S$ Rev. Hort. 56 : 324, pl. 
No other species of this type conld have been collected about San Diego, where $H$. Whipplei occurs in abundance, by Roezl, who in 1869 reintroduced it into European gardens through De Smet, under the name $Y$. Ortgiesiana, so that there appears no doubt as to the proper reference of this synonym.

On April 3d, 1858, Professor Newberry collected leaves of a plant "growing in tufts on rocks" at the mouth of Diamond river, at the eastern end of the grand cañon of the Colorado, in northern Arizona, which neither Professor Torrey* nor Dr. Engelmann could distinguish from those of this species as collected by Bigelow at the Cajon pass in California. The single leaf of Newberry's collection in the Engelmann herbarium is glaucous, falcate, elongated and scarcely to be referred elsewhere, - but the locality is so far from the known range of this species on the other side of the desert as to warrant doubt as to the correctness of the record, and I know of no confirmation of this isolated locality.

\section{CLISTOYUCCA (Engelmann) Trelease.}

Perianth oblong to globose, of nearly distinct thick oblong or lanceolate segments often incurved at end. Filaments nearly free, thickened, mostly outcurved above; anthers sagittate, horizontal. Ovary ovoid, tapering to the transiently stellate 6-lobed openly perforate stigma. Fruit dry, spongy about a papery core, 6-celled, indehiscent. Seeds rather thin, flat, nearly round; albumen not ruminated. - Large tree, with short thick and pungent roughmargined leaves and compact sessile panicle from an ovoid large-bracted bud.

\section{c. arborescens (Torrey) Trelease.}

Yucca Draconis (2) arborescens Torrey, Bot. Whipple. 147. (1857).

Y. brevifolia Engelmann, Bot. King. 496. (1871). Trans. Acad. St. Louis. 3 : 47, 213, 371. - Palmer, Amer. Journ. Pharm. 50 : 587. -

* Ives, Rept. npon the Colorado river of the West. Part IV. Botany. 29. 
Parry, Amer. Nat. 9: 141. - Watson, Proc. Amer. Acad. 14: 252. Bot. Calif. 2: 164. - Baker, Journ. Linn. Soc. Bot. 18: 221. Gard. Chron. n. s. $3: 492$. n. s. $26: 18$. ii. $1: 772, f .145$. Land of Sunshine. 10: 1. - Trelease, Rept. Mo. Bot. Gard. 4 : 193. pl. 6-9, 21. - Schimper, Pflanzengeographie. 669. f. 369.

Y. arborescens Trelease, Rept. Mo. Bot. Gard. 3: 163. pl. 5, 49. (1892). - Coville, Cuntr. U. S. Natl. Herb. 4: 201. frontispiece. Merriam, N. Amer. Fauna. 7: 353-8. frontispiece and pl. 13.Sargent, Silva. $10: 19 . p l .502$.

Large at length much branched rough-barked tree. Leaves spreading, less than $.3 \mathrm{~m}$. long, $15 \mathrm{~mm}$. wide, plano-convex or triquetrous, striate, minutely denticulate, very rigid, pungently pointed. Inflorescence sessile, dense, often scabrous-hispid. Flowers sometimes puberulent, greenish-white, 25 to $50 \mathrm{~mm}$. in diameter. Fruit ovoid, erect or variously directed, 50 to $100 \mathrm{~mm}$. long; seeds $10 \times 12 \mathrm{~mm}$. across, 1 to 1.5 mm. thick. - Plates 6. 7. 85, f. $10.87, f .1$.

Mohave desert, California, to Detrital valley, Arizona, and the Beaverdam mountains, Utah. - Plate 84, f. 2.

The Joshua tree of the Mohave desert region, the largest and most imposing of the Yucceae of the United States, which was first called Yucca Draconis (?) arborescens by Torrey, subsequently $Y$. brevifolia by Engelmann, and which is now commonly known as $Y$. arborescens, differs in its colleetive flower and fruit character about as much from typical Yuccas as does Hesperoyucca. In separating it from Yucca, I have thought best to apply to it as a generic name the sectional name Clistoyucca under which Dr. Engelmann * separates it from the other species of $Y u c c a$, since there can be no question as to the applicability of that name to this particular tree, though Dr. Engelmann $\dagger$ subsequently found it desirable to add $Y$. gloriosa to this section, to which the writer $\ddagger$ afterwards added $Y$. gigantea. Only the one species is known.

\section{YUCCA Linnaeus.}

Perianth open-campanulate, of nearly distinct thin lanceolate or ovate-lanceolate segments. Filaments nearly free,

* Bot. King. 496. Trans. Acad. Sci. St. Louis. $3: 47$.

$\uparrow$ Trans. Acad. Sci. St. Louis. 3 : 213.

$\mp$ Rept. Mo. Bot. Gard. 9 : 142. 
thickened and outcurved above; anthers short, sagittate, soon horizontal. Ovary oblong, mostly longer than the stout oblong or swollen style; stigma unequally 6-lobed, openly perforate. Fruit nearly or quite 6-celled: erect, capsular, 6-valved above, and with thin seeds with the albumen not ruminated ( $\$$ Chaenoyucca); variously pendent or erect, soon drying about a papery core, indehiscent, with thin seeds without rumination ( $\S$ Heteroyucca); or pendent, baccate mostly about a papery core, indehiscent, with very thick seeds having the albumen ruminated ( $\$$ Sarcoyucca). Acaulescent or arboreous plants occasionally of large size, with flaccid and pointless or usually rigid and very pungent entire, minutely denticulate, or filiferous leaves, and mostly ample panicle.

The true Yuccas, which (including Clistoyucca), in contrast with his section Hesperoyucca, Dr. Engelmann* treated under the sectional name Euyucca, have for many years been in cultivation in considerable numbers, and hence under the eyes of both gardeners and botanists, but no additions have been made to the number of known spontaneous species within recent years $\dagger$ except by the separation or rehabilitation of what had passed for varieties, forms or synonyms of described species, though some twenty years ago a number of hybrids, referred to below under $Y$. gloriosa, were introduced into cultivation, and it is certain that within the next few years our gardens will be still further enriched by many artificial hybrids between the known species.

This genus is not only larger than any of the others of the group Yucceae, but has a much greater geographical distribution, extending southwards from the great bend of the Missouri river to the table land north of the City of Mex-

- Bot. King. 496. (1871). Trans. Acad. St. Louis. 3 : 34.

$+Y$. Pringlei Greenman, distributed from Mt. Ajusco, Mexico, in 1897 (Pringle, No. 6669), was subsequently shown by Mr. Greenman to be Furcraea Bedinghausii. - Proc. Amer. Acad. 83 : 474. (1898). 
ico, and, after a break of unknown extent, into the center of Central America, and eastwards to the Atlantic coast and the Bermudas and eastern Antilles. The capsular species are the prevalent northern form, and reach from South Dakota to the Mexican state of Durango, and from the Atlantic coast to Nevada, with the exception of the Great Lake region and the upper Mississippi river and its tributaries from the east. The baccate species with papery core are of the southern Rocky Mountain and western region, reaching the Pacific coast in the southern part of California and at the extremity of Lower California, and are the prevalent form of the high table land of Mexico. A single species with coreless fleshy fruit appears to be restricted to the 8outhern Atlantic coast of the United States, a small part of the Gulf coast, and some of the islands to the east, though it has given rise to a marked variety in the isolated peninsula of Yucatan; and a single species with the foliage of this outlying species but forming a core in the fruit occurs in Central America, where, though abundantly cultivated, its distribution is unknown. Several species and many varieties are known only in gardens, and two species with very aberrant fruit are of local distribution on the southeastern seacoast of the United States. - Plate 99.

KEY TO SPECIRS.

Fruit erect, capsular, dehiscent. Seeds thin, flat, margined: albumen not ruminated.

§ СHAKNoYUCCA.

Leaves finely filiferous (entire in forms of the second).

Style oblong, white.

Inflorescence a long-peduncled panicle (subracemose in some garden forms of $Y$. flaccida).

Leaves lanceolate or spatulate, often plicate, at most very narrowly lined with gray or brown next the marginal threads.

Leaves rigid for the group, rather coarsely curlyfiliferous, subspatulate. Segments of young fruit regularly convex.

Y. filamentosa.

Leaves more flexible and attenuate, with finer straighter threads. Segments of young fruit with angular facets.

Y. flaccida. 
Leaves linear or linear-spatulate, white-margined.

Leaves grass-like. - Eastern Texas. Y. tenuistyla. Leaves more rigid and spreading. - Western.

Low. Seeds small.

Y. constricta.

Arborescent. Seeds very large.

$\boldsymbol{Y}$. radiosa.

Inflorescence racemose or branched close to the leaves. Not arborescent.

Leaves as in the last.

Leaves lanceolate, often short.

Style swollen, green.

Inflorescence racemose or branched close to the leaves.

Leaves linear, rather stiff. Seeds large. $\quad \boldsymbol{Y}$. glauca.

Leaves grass-like, flexible.

Y. Arkansana.

Inflorescence panicled on a long scape. Leaves as in the last or wider.

Y. Louisianensis.

Leaves with a distinct thin yellow or brown horny finely denticulate border.

Capsule mucronate, with flat-backed valves.

Arborescent. Leaves linear to lanceolate.

Y. rigida.

Acaulescent. Leaves lanceolate.

Y. rupicola.

Capsule attenuate-beaked, with round-backed valves.

Arborescent. Leaves linear.

Y. rostrata.

Fruit (so far as known) indehiscent.

Fruit erect or pendent, soon drying. Seeds thin, flat, slightly margined: albumen not ruminated. \$ HETEROYUCCA.

Leaves finely denticulate, softly green-polnted. $\quad$ Y. gigantea.

Leaves at most sparingly denticulate or fliferous, pungent.

Leaves broad, rigidly ascending or spreading. Fruit mostly pendent.

Y. gloriosa.

Leaves more elongated, recurved. Fruit erect so far as known.

Inflorescence close to the leaves, the latter relatively broad.

Y. recurvifolia.

Panicle long-stalked. Leares narrower. $Y$. flexilis.

Leaves crowded, regularly arcuate. $\quad Y$. De Smetiana.

Fruit pendent, fleshy and edible. Seeds thick, often convex, nearly or quite marginless : albumen ruminated.

$\S$ SARCoYucCa.

Fruit coreless, with purple pulp. Ovary stalked. Leaves with sharply denticulate horny border.

Y. aloifolia.

Fruit with a papery core and greenish or yellowlsh-white pulp. Ovary sessile.

Leaves very minutely denticulate, not fliferous, flat or plicate.

Y. elephantipes.

Leaves soon more or less flliferous, concave.

Margin at first slightly denticulate. Leaves thick and firm, scabrid

Y. Treculeana.

Not denticulate. 
Thin, flexible: threads sparing, fine. Y. Schottii. Thick, rigid, with nsually coarse threads. Leaves narrow, smooth. Small tree. $\quad Y$. brevifolia. Leaves relatively broader, usually smooth.

Large trees.

Panicle narrow, pendent. $\quad Y$. australis.

Panicle broad, erect, to recurved $Y$. valida.

Leaves large, very coarsely filiferous, the back very scabrous except in the last.

Acanlescent. Flowers very large for the genus: style elongated. $\quad$ Y. baccata. Arborescent. Flowers of average size. Style elongated.

Y. macrocarpa. Style short.

Y. Mohavensis.

sYNOPSIS OF SPECIES.

A. Fruit erect, capsnlar, dehiscent. Seeds thin, flat, margined: albumen not ruminated. - $\$$ Chaenoyucca.

1. Leaves finely flliferous at the margin (entire in aberrant garden forms of the second).

2. Style oblong, white.

3. Inflorescence a long-peduncled panicle (reduced to a simple raceme in aberrant forms or secondary inforescences of the second).

4. Leaves lanceolate or spatulate, often plicate, not conspicuously white-margined.

Y. Filamentosa Linnaeus, Sp. Pl. 319. (1753).Walter, Fl. Carol. 124. - Michaux, Fl. 1 : 196. Pursh, Fl. 1 : 227. - Gawler, Bot. Mag. 23. $p l$. 900.- Redouté, Liliacées. 5. pl. 277-8. - Haworth, Syn. Pl. Succ. 70. - Gambold, Amer. Journ. Sci. 1819 : 251. - Mordaunt, Herb. Gén. 4. pl. 258. Elliott, Bot. S. C. and Ga. 1: 400. — Frost, Plants Abbeville Distr. 317. — Lemaire, Ill. Hort. 13 : 98. Porcher, Resources So. Fields and For. 530.Curtis, Bot. N. C. 56. - Engelmann, Trans. Acad. St. Louis. 3 : 52, 214. - Baker, Gard. Chron. 1870 : 923. Journ. Linn. Soc. Bot. 18 : 227. - Britton \& Brown, Ill. Fl. 1 : 427.f. 1027. - Möller's Deutsche 
Gärtner-Zeit. 11 : 361. $f$. - Mohr, Contr. U. S. Natl. Herb. $6: 441$, as to southern localities.

Yuca folíis flamentosis. Morison, Plant. Hist. 2 : 419. Sect. 4. pl. 23. (1680).

Juca Americana flamentosa. Munting, Waare Oeffening der Planten. 471. f. (1682). Naauwkeurige Beschryv. der Aardgew. 663. (1696). Yucca Virginiana, foliis per ambitum apprimè flatis. Plukenet, Almag. Bot. 396. (1696). - Raius, Hist. Plant. 3 : 573. (1704).

Yucca folitis lanceolatis etc. Trew. Pl. Sel. 9. pl.37. (1754).

Yucca folis lanceolatis acuminatis integerrimis margine flamentosis. Gronovius, Fl. Virgin. 152. (1739). 53. (1762).

Acaulescent, cespitosely suckering. Leaves rather flrm, generally stiffly erect or spreading, about half a meter long, usually something. over $25 \mathrm{~mm}$. wide, narrowed above the base, attenuate or typically abruptly acute, occasionally somewhat pungent, green or a little glaucous, the back frequently roughened in lines; marginal threads rather thick and curly for the group. Inflorescence 1.5 to 3 or $4 \mathrm{~m}$. high, longpedunculate, glabrous or very exceptionally puberulent. Flowers white, usually tinged with cream color or green or rarely browned, expanding 50 to $75 \mathrm{~mm}$.; style white, elongated, at most slightly swollen, 3-grooved. Capsule apple-green and with regularly convex carpels when maturing, 50 or $60 \mathrm{~mm}$. long and brown when ripe: seeds glossy, 4 to $5 \times 7 \mathrm{~mm}$. Plates 8-12.79.87.

In a generalized sense, a species usually of the coastal plain of the southeastern Atlantic region, from Tampa, Fla., to above Charleston, S. C., and extending back to northwestern Georgia, west-central North Carolina, southwestern Alabama, and the gulf coast of Mississippi. - Plate 87, f. 1 .

The principal forms appear separable as follows:-

Leaves of medium size, little recurved.

Y. filamentosa.

Variegated with white or yellow.

f. variegata.

Outer leaves attenuate, recurved, the inner very broadly

lanceolate, erect.

Leaves narrow, very spreading.

var. media.

Leaves very long, attenuate, recurving.

var. patens.

Leaves very broadly spatulate, not recurved.

var. bracteata.

var. concava.

\section{Y. FILAMENTosA Linnaeus.}

Synonymy as above. 
Leaves 25 to $40 \mathrm{~mm}$. wide, gradually acute, rather rigid, striate, the outer rarely recurving. Petals broad, acute. Capsules rather narrowly cylindrical. - Plates $8.12, f .1$.

West-central North Carolina to southeastern South Carolina, Florida from Jacksonville to Tampa, and doubtless in the intervening country. - Plate $85, f .1$.

Y. Filamentosa variegata Carrière, Rev. Hort. 1860: 215. - Naudin, Plantes Feuill. Coloré. 1. pl. 51.Lowe, Beautiful Lvd. Plants. 105. pl. 51. - Garden. 1:152.f. 27:266, 309. 32:600._Gardeners' Chron. n. s. $7: 341$. n. s. $13: 594$. n. s. $23: 803$.

? Y. Alamentosa aurea elegantissima Wiener Ill. Gart.-Zeit. 5: 389. (1880).

Y. filamentosa bicolor Hort.

Y. recurvifolia Park \& Cemetery. 11 : $184 . f$.

Leaves margined and striped with various shades of white and yellow. A garden sport, or series of sports, the color extremes of which should doubtless bear distinctive horticultural names.

Y. Fllamentosa patens Carrière, Rev. Hort. 1860 : 216.

Y. filamentosa Mohr, Contr. U. S. Natl. Herb. 6:441, in part.

Leares rather rigidly spreading, 15 to $20 \mathrm{~mm}$. wide, gradually attenuate to a sharp point.

From northwestern to southeastern Georgia. - Plate 85, f. 2 .

Y. filamentosa bracteata Engelmann, Trans. Acad. St. Louis. 3: 52-3. (1873). - Watson, Proc. Amer. Acad. 14 : 254 . - Baker, Journ. Linn. Soc. Bot. 18 : 228.

? Y. fllamentosa maxima Carrière, Rev. Hort. 1860 : 213.

Very large, with elongated leaves, the outer recurved, mostly large foliaceous scape bracts, more frequently puberulent panicle sometimes nearly $5 \mathrm{~m}$. high, and more attenuate petals. Capsule narrowly oblong, mucronate-beaked. - Plate 9 .

About Charleston, S. C., and doubtless along the adjacent Georgia ccast, where it is sometimes seen in cultivation. 
Simulating in aspect or bract characters cultivated forms of Y. flaccida. - Plate 86, f. 1.

Y. Filamentosa concava (Haworth) Baker, Journ. Linn. Soc. Bot. 18 : 228. (1880).

Y. concava Haworth, Suppl. Pl. Succ. 34. (1819). - Lemaire, Ill. Hort. 13 : 98.

Y. flamentosa latifolia Engelmann, Trans. Acad. St. Lonis. 8 : 52. (1873).

General characters of the type, into which it appears to pass, but the usually very plicate abruptly acnte or obtuse leaves deeply concave and spatulately enlarged to a width of as much as $100 \mathrm{~mm}$. - Plates 10.79 , f. 1 .

About Charleston, S. C., to below Savannah, Ga., at Salisbury, Md., and doubtless in much of the intervening coast region. - Plate $86, f .2$.

Y. fillamentosa media Carrière, Rev. Hort. 1860 : 213. $f .47-8$.

Y. filamentosa laevigata Engelmann, Trans. Acad. St. Louis. 3 : 52, 54, 214. (1873). - Watson, Proc. Amer. Acad. 14 : 254. - Baker, Journ. Linn. Soc. Bot. 18 : 228.

Y. filamentosa Journ. of Hort. 52 : 271. $f$.

? Y. flaccida Lindley, Bot. Reg. 22. pl. 1895. - Baker, Ref. Bot. 5 . text to $p l .323$.

? Y. puberula Baker, Ref. Bot. 5 . pl. 322, - not text.

? Y. glauca Baker, Ref. Bot. 5 . pl. 315.

Leaves rather thinner, the outer gradually more attenuate and recurved, the inner broadly lanceolate; the marginal threads straighter. Inflorescence mostly puberulent and sometimes tomentose. - Plate 11 .

A garden form, passing towards $Y$. flaccida glaucescens and $Y$. Louisianensis.

Y. Flaccida Haworth, Suppl. Pl. Succ. 34. (1819).Lemaire, Ill. Hort. 13: 99. - Baker, Gard. Chron. 1870: 923 . Ref. Bot. 5. pl. 323.

Y. puberula Haworth, Phil. Mag. 1828: 126. - Sweet, Brit. Fl. Gard. pl. 21. - Lemaire, Ill. Hort. 13:99. - Baker, Gard. Chron. 1870: 923.

Y. filamentosa flaccida Engelmann, Trans. Acad. St. Louis. 3 : 52, 214. 
(1873). - Watson, Proc. Amer. Acad. 14 : 254. - Baker, Journ. Linn. Soc. Bot. $18: 228$. - Garden. $58: 447$. $f$.

Y. filamentosa puberula Baker, Journ. Linn. Soc. Bot. 18: 228. (1880).

I. filamentosa Gattinger, Tenn. Flora. (1887). 58. (1901). 86. - Mohr, Contr. U. S. Natl. Herb. $6: 441$, as to northern localities. - Garden. 58:445. $f$. - Park and Cemetery. $11: 184$. $f$.

I. Meldensis Garden. 8:147. (1875).

Acaulescent, cespitose. Leaves thin, flexible, the outer almost always recurved, 10 to $40 \mathrm{~mm}$. wide, elongated lanceolate, very gradually long attenuate, mostly plicate, with fine long and rather straight thin marginal fibers except in two threadless garden forms. Panicle mostly pubescent. Maturing capsule dull grayish-green, the carpels variously and irregularly flattened in places, as if shaved off with a knife; when ripe, broad, usually constricted, and mostly flaring above: seeds rather dull, larger, 7 to $8 \times 8$ to $10 \mathrm{~mm}$. - Plates 12-17. 76 . 79 .

Asheville, N. C., to Gadsden and Anniston, Ala., in and near the mountains. - Plate 87, f. 2.

Occasional simple racemes are produced from small lateral crowns, when the main crown is in bloom (Plate 13), as has been observed on some species of Agave, and one depauperate garden form produces an unbranched main inflorescence.

An interesting winter adaptation of the foliage of this species is readily observed in the North whenever the temperature remains for any time below the freezing point, for at and below this temperature the spreading unflexed middle leaves, which are ordinarily somewhat concave, have their margins rolled inwards so as nearly or quite to meet at the center, though they scarcely become involute in the proper meaning of that word. (Plate 14).

The numerous intergrading garden forms of $Y$. faccida seem capable of most natural arrangement as follows:-

Petals broad, acute or acuminate. Panicle mostly pubescent. Y. flaccida.

Inflorescence a raceme.

f. orchioides.

Petals usually more lanceolate, attenuate.

Leaves filiferous.

Panicle very pubescent.

Leaves transiently variegated.

var. glaucescens.

f. lineata. 
Panicle mostly glabrous.

var. grandiflora.

Leaves without marginal threads.

Panicle pubescent.

f. exigua.

Panicle glabrous; petals biunter.

f. integra.

Y. FlaCcida Haworth.

Synonymy as above.

Leaves rather green, scarcely $25 \mathrm{~mm}$. wide, very flexible. Panicle moderately pubescent to glabrous. Petals usually broad and rather short. - Plate 16.

The commoner wild form.

$Y$. Meldensis of gardens appears to differ only in having more spreading panicle branches, in which it agrees with some garden forms of $Y$. filamentosa.

\section{Y. flaccida orchioides (Carrière) Trelease.}

Y. orchioides Carrière, Rev. Hort. 1861 : 370. f. 89, 90. - Lemaire, Ill. Hort. 13 : 99. - Baker, Gard. Chron. 1870 : 1122. - Engelmann, Trans. Acad. St. Louis. $3: 43$.

A depauperate garden form with stiffer more erect nearly threadless leaves, and racemose inflorescence.

Y. flaccida glaucescens (Haworth) Trelease.

Y. glaucescens Haworth, Suppl. Pl. Succ. 34. (1819). - Sweet, Brit. Fl. Gard. $p l$. 53.-Bommer, Journ. d'Hort. Prat. 1859:41. Lemaire, Ill. Hort. 13:98. - Baker, Gard. Chron. 1870:923. Hemsley, Garden. 8 : 132.

Y. filamentosa glaucescens Baker, Journ. Linn. Soc. Bot. 18: 228. (1880).

$\boldsymbol{Y}$. filamentos $\alpha$ Antwerpensis Baker. $l$. c.

Y. orchioides major Baker, Bot. Mag. iii. 33. pl. 6316. (1877).

Y. flaccida Carrière, Rev. Hort. 1859 : 555. f. $119,120$.

Y. filamentosa Baker, Ref. Bot. 5. pl. 324. - Rept. Mo. Bot. Gard. 3. $p l$. 10. - Amer. Florist. 8: 55. $f$.

A more glaucous form, with the leaves mostly broader and erect untll a later period, almost tomentose panlcle, and more attenuate petals. Plates 12,f. 2. 13-15. 17,f. 1. 76,f. 2. 79, f. 2.

The common form of American gardens. 


\section{Y. flaccida lineata Trelease.}

A garden sport, apparently of var. glaucescens, but in habit more resembling $Y$. filamentosa media, having the young leaves striped with dingy or yellowish white, the variegation soon fading for the most part.

Cultivated at the Missouri Botanical Garden and said to have come from Haage \& Schmidt in 1881. Doubtless it is this by which the variegated form of $Y$. filamentosa proper is represented in many gardens.

Y. flaccida exigua (Baker) Trelease.

Y. exigua Baker, Ref. Bot. 5. pl. 314. (1872). Journ. Linn. Soc. Bot. 18 : 223 . - Engelmann, Trans. Acad. St. Louis. 3 : 43.

A garden form of var. glaucescens with the leaves without marginal threads.

Y. flaceida grandiflora (Baker) Trelease.

Y. filamentosa grandiflora Baker, Ref. Bot. 5. pl. 325. (1872)

Y. filamentosa maxima Baker, Journ. Linn. Soc. Bot. 18:227. (1880).

Y. filamentosa Garden. $1: 152 . f .12: 72 . f$. - Gartenflora. 24 : 372.

f. - Wiener Ill. Gart.-Zeit. 13 : 119. f. - Step, Favourite Flowers.

4. $p l .272$.

Scarcely more than a large sometimes glabrous form of var. glaucescens, in aspect resembling $Y$. filamentosa bracteata.

\section{Y. flaccida integra Trelease.}

Y. glauca Sims, Bot. Mag. 53. pl. 2662. (1826). - Regel, Gartenflora. 8 : 36. - Bommer, Journ. d'Hort. Prat. 1859 : 43. - Lemaire, Ill. Hort. 13 : 97. - Engelmann, Trans. Acad. St. Louis. 3 : 43, 53. - Baker, Gard. Chron. 1870 : 1122 . Journ. Linn. Soc. Bot. 18 : 223.

Scarcely more than a narrow-leaved glabrous form of $\mathbf{f}$. exigua.

The name employed by Sims is antedated thirteen years by $Y$. glauca Nutt.

The filiferous-leaved " bear grasses " of the southeastern Atlantic States are not easily disposed of in an attempt to monograph the genus to which they belong, partly because they are more commonly seen in cultivation than in a state of nature, partly because of their interblending characters, 
and partly because of generalized earlier descriptions. One of the representatives of this group (probably true $Y$. filamentosa) was introduced into Europe about 1675, and $Y$. filamentosa was one of the four Yuccas known to Linnaeus a century later, his description of it reading merely "foliis serrato-filamentosis," and the only figure cited by him * being very unsatisfactory.

That two species, $Y$. filamentosa and $Y$. flaccida, are separable, appears certain, as is also true of Engelmann's conclusion $\dagger$ that the filamentosa of Linnaeus was the form to which that name is here applied; but I have found it possible to fix only an approximate geographical range for either, and the garden forms are not separated as sharply as is desirable, nor so as to prevent some of them from obscuring the demarcation line between the species. It is not improbable that some of them represent hybrids between the latter.

44. Leaves linear or linear-spatulate, white-margined.

\section{Y. tenuistyla Trelease.}

Acaulescent. Leaves rather soft and mostly recurving, often a little scabrid on the back, about .5 m. long and 10 to $15 \mathrm{~mm}$. wide, dark green, lanceolate, long-attenuate, scarcely pungent, white-margined, flnely fliferous. Inflorescence about $1 \mathrm{~m}$. high, panicled at some distance above the leaves, glabrous or slightly puberulent. Flowers with narrower, more pointed segments: style oblong, white, often deeply parted. Capsule stout, even: seeds glossy, 7 to $8 \times 8$ to $10 \mathrm{~mm}$. - Plates 1 7, f. 2. 18. 19 . $83, f .3$.

Southeastern Texas, from about Galveston (Lindheimer, May, 1843), to Sealy (Trelease, Harvey), and New Braunfels (Lindheimer, June, 1845), at the latter place associated with $Y$. Arkansana, which it closely resembles in foliage. - Plate $92, f .1$.

Some of the Lindheimer material in the Engelmann her-

* Morison, Plant. Hist. 2 : 419.

$\dagger$ Trans. Acad. St. Louis. 3 : 52. 
barium consists of loose flowers, some of which have a short thick green style, while others have the style longer, slenderer, and white; while the fragments of inflorescence are equally suggestive of mixed material, some of which was from racemes while the rest represent panicle branches. Field observation the present season, and material received from Mr. J. Reverchon, of Dallas, and Mr. J. A. Harvey, of Sealy, confirm the conclusion reached, that the grass-leaved Yuceas of eastern Texas comprise three species, $Y$. Arkansana, $Y$. Louisianensis, and the one here characterized.

Y. constricta Buckley, Proc. Acad. Nat. Sci. Philadelphia. 1862 : 8. - Gray, Proc. Acad. Phila. 1862 : 167. Engelmann, Trans. Acad. St. Louis. 3:213. Bot. Gazette. 7 : 17 .

? Y. alba-spica Koch, Belg. Hort. 12 : 111. (1862), - Rev. Hort. 1865 : 151. 48 : 432. - ? Flore des Serres. $17: 110 . f .1612$. - Engelmann, Trans. Acad. St. Louis. 3 : 213. - Garden. $8: 147$.

Y. angustifolia Carrière, Rev. Hort. 1860:20. f. 3, 4. 1864:151. Garden. 8: 134. f. - Bray, Bot. Gaz. 32:280, in part*.

Y. glauca Bray, 1. c. 271. f. 18, in part*.

Low or acaulescent. Leaves rather rigidly divergent, about $10 \mathrm{~mm}$. wide, whitish green, the white margin soon shredding into fine threads. Inflorescence about $1.5 \mathrm{~m}$. high, rather amply branched at top. Flowers white, globose-campanulate, with broad segments: style white, more or less tumid. Capsule constricted, flaring above, dark, with a ridge over each false septum: seeds 5 to $6 \times 7$ to $9 \mathrm{~mm}$. - Plates 20.21, f. 1 . 83 , f. 4 .

Seward County, Kansas, to the Pecos river region of Texas. - Plate 92, f. 2 .

Among other plants from western Texas which Mr. S. B. Buckley characterized about forty years ago was a Yucca

* As is more clearly shown in a print from his negative, furnished me by Professor Bray, than in his published figure, the latter represents two species, - Y. glauca, with simple racemes in full bloom, and $Y$. constricta, with branched pedunculate inflorescence still in bud. 
which he called $Y$. constricta, and described as being shortly caulescent with leaves similar to but shorter than those of the Rocky Mountain species now called Y. glauca, longstalked panicle, and capsules constricted in the middle. When Dr. Engelmann raised to specific rank the arborescent species that replaces this to the west, under the name $Y$. elata, ${ }^{*}$ he was particular to exclude from it $Y$. constricta, which he regarded as a caulescent form of $Y$. glauca; but this conclusion, which did not accord with the description of fruit and inflorescence given by Buckley, was subsequently changed by him $\dagger$ and has not been followed by other writers, who have considered $Y$. elata and $Y$. constricta to be synonymous. $\ddagger$

From observations made about Putnam, Texas, in 1892, $\S$ and at various points west of San Antonio in 1900, I should say that $Y$. constricta is quite distinct from both the preceding and the next species, differing from the former in its narrower and firmer leaves and more ample inflorescence, and from the latter in its usually very short stem, smaller constricted dark capsules, and much smaller seeds.

Among a number of plants selected by Mr. James Gurney a few years since in Seward County, Kansas, for the demonstration of the great variability in the leaves of $Y$. glauca, is one which in foliage could hardly be distinguished from the usual form of that species, or the somewhat broader-leaved variety by which the latter is represented in that part of Kansas, but which, on blooming in the Missouri Botanical Garden in 1900 produced a rather ample long-pedunculate panicle of pure white flowers, with white styles, which began to expand with the

* Bot. Gazette. 7 : 17. (1882).

† Trans. Acad. St. Louis. 3 : 213.

† Baker, Journ. Linn. Soc. Bot. 18 : 229. — Sargent, Silva. 10 : 27.

§ Rept. Mo. Bot. Gard. 4:207, under $Y$. glauca stricta ( $=Y$. Arkansana). 
first flowers of $Y$. flaccida, which they closely resemble, and at the end of the flowering period of $Y$. glauca and its variety stricte. It is hard to see how this plant can be separated from $Y$. constricta. What appears to be the same has been collected by Dr. Kleinschmidt at Mt. Kiowa, Okl., and the character of the intervening country is such as to make its extension probable from southwestern Kansas to the Pecos river of Texas, while Professor Bray's photograph referred to above shows it to be a characteristic plant of the staked plains.

Y. RadiosA (Engelmann) Trelease, Rept. Mo. Bot. Gard. 3: 163. (1892).

Y. angustifolia rediosa Engelmann, Bot. King. 496. (1871).

$Y$. angustifolia elata Engelmann, Trans. Acad. St. Louis. 3 : 50, 51. (1873). - Watson, Proc. Amer. Acad. 14 : 253.

F. elata Engelmann, Bot. Gaz. 7 : 17. (1882). - Coulter, Contr. U. S. Natl. Herb. 2 : 437. - Garden. 36 : 573. - Gard. \& Forest. 2 : 568. f. 146. 9: 313. - Rept. Mo. Bot. Gard. 3 : 164. pl. 9. 4:201. pl. 10, 15, 22. - Bot. Mag. iii. 55. pl. 7650 .

Y. constricta Baker, Journ. Linn. Soc. Bot. 18 : 229. - Sargent, Silva. 10 : 27. pl. 504 . - In part.

Y. angustifolia Havard, Proc. U. S. Natl. Mus. 8 : 470.

Caulescent, the larger trees reaching a height of 5 to $7 \mathrm{~m}$., simple or with a few short branches at top. Leaves pallid, rather rigidly divergent, long, 3 to 10 or rarely $13 \mathrm{~mm}$. wide, white-margined and soon finely and copiously flliferous. Inflorescence large, panicled on a long exserted peduncle, glabrous. Flowers white, bell-shaped, with lanceolate attenuate segments: style white, oblong. Capsule oblong, smooth, not or rarely constricted, with ribless convex valves, straw-colored: seeds rather dull, 8 to $10 \times 12$ to $15 \mathrm{~mm}$. - Plates 21, f. $2.22 .83, f .5$. $s 6, f .1$.

Southern Arizona to the Rio Grande, as far as the big bend, and south to about the eity of Chihuahua. - Plate $93, f .1$.

In describing the Yuccas for Watson's Botany of the Fortieth Parallei, Dr. Engelmann characterized an arborescent plant with large panicles and lanceolate petals under 
the name $Y$. angustifolia $\beta$. radiosa, which varietal name, two years later, he replaced by the varietal name elata which was still later applied specifically by him.

With Mr. Baker, and against the opinion of Engelmann, Professor Sargent identifies this plant with the earlier $Y$. constricta of Buckley and applies the latter name to it. As has been stated above, however, there is reason to believe that $Y$. constricta is really a distinct species of more eastern and northern range, and to the present one the name radiosa, first used varietally by Engelmann, is applicable as a specific name.

As in $Y$. glauca, the fruit of this species is stout, oblong, and unusually symmetrical among the capsular species, and it is here very smooth and of a clear straw-color at maturity, and the seeds are exceptionally large. The leaves, which are usually about $6 \mathrm{~mm}$. wide, occasionally reach a minimum of $3 \mathrm{~mm}$. and a maximum of about $12 \mathrm{~mm}$., but both the broad- and narrow-leaved trees occur associated with the usual form, from which they do not appear otherwise distinguishable.

So far as can be told from young leaves from Mr. Baker, in the Engelmann herbarium, Y. polyphylla Baker,* which its author subsequently $\dagger$ treated as a synonym of $Y$. radiosa, under the name $Y$. constricta, - is more likely to have been based on an immature and aberrant garden seedling of $Y$. filifera than one of the representatives of this group, since the leaf possesses a distinct brown margin, very different from the white margin of $Y$. radiosa and its allies, which at most very exceptionally has a narrow brown line between the white border and the green body of the leaf. Though $Y$. alba-spica (or albospica as it is commonly written) seems to refer to the

* Gard. Chron. 1870 : 1088.

† Journ. Linn. Soc. Bot. 18 : 229. 
preceding rather than the present species, the latter is doubtless now in cultivation under that name. *

For some reason this very striking Yucca does not appear to have been collected or commented on by the botanists of the original boundary survey, though it is abundant in the Rio Grande valley about Presidio. The botanists of the later survey seem to have passed in by for $Y$. glauca, which I have not seen from so far south.

33. Inflorescence racemose or branched close to the leaves. Subacaulescent plants.

Y. angustissima Engelmann, in herb.

Y. glauca Coville, Contr. U. S. Natl. Herb. 4 : 202.

Y. radiosa Coville, 1. c. 203, 277.

Y. elata ? Merriam, N. A. Fauna. 7: 358.

Acaulescent, from thick horizontal root-stocks. Leaves as in the narrowest forms of $Y$. radiosa and $Y$. glauca, 2 to $5 \mathrm{~mm}$. wide, .2 to $.4 \mathrm{~m}$. long, pungent, white-bordered, very freely and often curly-flliferous below. Inflorescence glabrous, 1 to $1.5 \mathrm{~m}$. high, racemose, or shortbranched below. Perianth segments rather short, mostly acutely lanceolate: style as in the preceding. Capsule scarcely exceeding $50 \mathrm{~mm}$. in length, rough, brown, constricted, with a median rib on each valve: seeds glossy, 5 to $7 \times 7$ to $8 \mathrm{~mm}$. - Plates $23, f .1 .24, f .1 .83, f .6$.

Southwestern Utah, southeastern Nevada, and northwestern Arizona, in the region of the Colorado river. Plate 93, f. 1 .

In habit, this species, which is briefly referred to without name by Professor Sargent, $\uparrow$ recalls the narrow-leaved form of $Y$. glauca as found, for example, about Albuquerque, N. M., or the narrowest-leaved forms of $Y$. radiosa, when the latter is acaulescent. From the former it differs in its more frequently branched inflorescence, oblong (white ?) style, and smaller capsule and seed; and from the latter in never becoming a tree and in its subsimple inflorescence, smaller, rougher and darker, constricted capsules, and much

* See Baker, Kew. Bull. 1892 : 8.

+ Sargent, Silva. $10: 28$. Note. 
smaller seeds. Specimens examined: — "Deserts of the Colorado river" (Bigelow in 1853 and 1854); Grand cañon region, Ariz. (Toumey in 1892, Trelease in 1901); "Arizona" (Palmer, 799); "Southern Utah, northern Arizona, \&c." (Palmer in 1877); St. 'George, Utah (Palmer in 1870); and La Verken, Utah (Jones, 5180).

\section{Y. Harrimaniae Trelease.}

Acaulescent, often cespitose. Leaves linear to spatulate-lanceolate, usually 6 to 15 , or even $40 \mathrm{~mm}$. wide, thin but flrm, rigidly spreading, glaucous, or green with age, concave, pungent, narrowly brown-bordered, with relatively coarse, at length circinate, white marginal flbers. Inflorescence .25 to $.5 \mathrm{~m}$. high, simple, flowering from close to the base, glabrous. Flowers greenish, large, with broad often obtuse segments : style slender. Capsule brown, broadly oblong, about $40 \mathrm{~mm}$. long, constricted, flaring above, the valves sometimes attenuate-mucronate: seeds 4 to $5 \times 5$ to $6 \mathrm{~mm}$. - Plates 28. 29. 83, f. 10 .

Utah:- Cedar City (Parry, July 6, 1874), Near Kingston (Jones, 5322), Helper (Trelease in 1899 and 1901), to western Colorado:-Cimmaron (Baker, 281), - on gravelly hillsides. - Plate $93, f .1$.

A very distinct species, often flowering when the leafrosette is not over a span wide, the broadly spatulate foliage of these small plants being strikingly unlike that of any other mature Yucca. My first acquaintance in the field with this plant resting upon the detention of our train at Helper, Utah, because of a washout, on the return of the Harriman Alaska Expedition, I take pleasure in dedicating it to our hostess on that occasion, Mrs. Edward H. Harriman.

22. Style stout, green.

3. Inflorescence racemose or branched close to the leaves.

Y. Glauda Nuttall, Fraser's Cat. no. 89. (1813). - Pittonia. 2 : 115. - Coulter, Contr. U. S. Natl. Herb. 2 : 437. - Trelease, Rept. Mo. Bot. Gard. 4: 205. 6. $p l$. facing p. 7.-Schimper, Pflanzengeographie. 
677. f. 384. - Bush, Rept. Mo. Bot. Gard. 6: 122, 133. - Britton \& Brown, Ill. Fl. 1: 427.f. 1026. Bray (in part*), Bot. Gaz. $32: 271 . f .18$.

Y. angustifolia Pursh, Flora. 1 : 227. (1814). - Nuttall, Gen. 1 : 218. Sims, Bot. Mag. 48. $p l$. 2236. - Bommer, Journ. d'Hort. Prat. 3: 41. - Lemaire, Ill. Hort. 13 : 99. - Baker, Gard. Chron. 1870: 923. Journ. Linn. Soc. Bot. 18 : 226. - Engelmann, Bot. King. 496. Trans. Acad. St. Louis. 3 : 50. - Palmer, Amer. Journ. Pharm. 50 : 587. - Watson, Proc. Amer. Acad. 14: 253. - Gard. \& Forest. 2 : 244, 247. f. - Garden. 58 : 446. - Rept. Mo. Bot. Gard. 3 : 163. pl. $8,51 .-$ Wiener Ill. Gart.-Zeit. $12: 35 .-$ Bray (in part*), Bot. Gaz. 32 : 280.

? Y. Hanburii Baker, Kew. Bull. 1892 : 8, 217. Gard. Chron. lii. 11 : 749. - Wiener Ill. Gart.-Zeit. 17 : 433.

Subacaulescent or with branching prostrate stem. Leaves rather rigidly divergent, 6 to $12 \mathrm{~mm}$. wide, pallid, white-margined, soon finely but usually sparingly flliferous. Inflorescence 1 to $2 \mathrm{~m}$. high, simple or with an occasional short included branch, floriferous from near the base, glabrous. Flowers greenish-white, globose or oblong, campanulate, the segments varying from broad and acute to longer and more attenuate; style green, tumid. Capsule large, oblong, usually not constricted, somewhat roughened, brown: seeds very glossy, 7 to $9 \times 11$ to $13 \mathrm{~mm}$.Plates 23,f.2. 24, f. 2. 25. 83, f. 9.

Central South Dakota and southern Wyoming, to northwest Missouri, Central Kansas and the vicinity of Santa Fé, New Mexico. - Plate 93, f. 1.

The usual form from Trinidad southward is prevailingly narrower-leaved than that of the north and east.

This low capsular bear-grass or soap-weed of the central Rocky Mountain region and northern plains, is almost invariably marked by a simple inflorescence, not carried on a scape above the cluster of leaves. Only exceptionally are any branches formed on the panicle, and then these, which are toward its base, are very small and few in number, though when the developing inflorescence has been injured a greater development of these potential rudimentary basal branches is observed.

\footnotetext{
* See note under $Y$. constricta above.
} 
European gardens contain, under the name $Y$. angustifolia, plants which are very different from the Yucca socalled by Pursh. In 1860, Carrière,* giving $Y$. albo-spica as a synonym, described and figured one such plant, with long-exserted glabrous panicle and rather broad filiferous leaves, which, with Mr. Baker, $\dagger$ I should more readily refer to $Y$. constricta than elsewhere, and Mr. Baker $\ddagger$ states that $Y$. flexilis also occurs in gardens under this name. From the original description, $Y$. Hanburii possesses quite the inflorescence of $\boldsymbol{Y}$. glauca; but has the leaves a little rough on the back and with a line of brown between the green tissue and the marginal line of white. I should have thought of connecting with it the narrower leaves of the preceding species, because of these characters, had not the Kew authorities given me positive assurance that the two are very distinct.

Y. glauca stricta (Sims) Trelease.

Y. stricta Sims, Bot. Mag. 48. pl. 2222. (1821).-Bommer, Journ. d'Hort. Prat. 3 : 41. - Lemaire, Ill. Hort. 13 : 95. - Baker, Gard. Chron. 1870 : 923. - Hemsley, Garden. $8: 130,132 . f_{\bullet}-\mathrm{As}$ to Sims citation only.

Y. angustifolia stricta Baker, Journ. Linn. Soc. Bot. 18:227. (1880). As to Sims citation only.

Of the habit of the northern form of $\boldsymbol{Y}$. glauca, but of more vigorous growth, and with longer, more erect stem. Leaves very long, $12 \mathrm{~mm}$. or less wide, at first somewhat glaucous, the entire white margin quickly shredding into slender fibers. Infiorescence usually tall, occasionally simple but typically paniculately branched within or close to the cluster of leaves. Flowers greenish white, often purple-tinted, varying from globose to oblong-campanulate, and with correspondingly short and blunt or acutely attenuate perianth segments: style greatly swollen at base, green. Capsule and seeds unknown. - Plates 26.27.

Seward County, Kansas, and doubtless elsewhere on the plains.

In 1821, Dr. Sims applied the name Yucca stricta to a

* Rev. Horticole. 1860 : 20-22. f. 3-4.

$\dagger$ Journ. Linn. Soc. Bot. 18: 229.

†1. c. 224. 
filiferous-leaved plant, said to have been introduced a few years before from the Carolinas, by Mr. Lyon, and to have been confused, up to the time of its description, with $Y$.

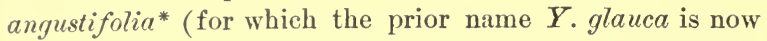
commonly employed). The good illustration that he gives, and which is copied by Hemsley, shows, as the description indicates, that the plant is quite of the habit of $Y$. glauca, with similar narrow leaves and violet-tinged greenish flowers having the swollen green stigmas of $Y$. glauca; but the panicle is much branched below, the rather long branches reaching about to the top of the uppermost leaves, and the flowers are subglobose, with broad blunt perianth segments, in neither of the latter respects, however, differing from some specimens of $Y$. glauca.

Yucca stricta, ever since its establishment, has been a puzzle to botanists, partly because no plant exactly corresponding with Sims' figure seems to have been reported since then, and partly because M. Carrière, $\dagger$ and following him, Mr. Baker, $\ddagger$ confused with it a garden plant, which, in fact, appears to be $Y$. Louisianensis. In his article in The Garden,§ Mr. Hemsley copies the original illustrations of both forms, though treating them as pertaining to one species. Both Baker and Hemsley mention herbarium specimens collected by Drummond in Texas and near New Orleans, as representing their Yucca stricta, which Mr. Baker subsequently called $Y$. angustifolia var. $Y$. stricta\| and which cannot well be the stricta of Sims or of Carrière, but is what is here called $Y$. Arkansana or $Y$. tenuistyla, or both. It is interesting to note that although much collecting has been done in the South Atlantic region since the time of Sims' publication of Yucca stricta, no green-styled species of the alliance of

* On this see Nuttall, Genera 1 : 218. (1818).

† Rev. Horticole. $1859: 466-470$. f. 101-2.

‡ Gard. Chron. 1870: 923.

§ Garden. 8: 130, 132, 140. (1875).

|| Journ. Linn. Soc. Bot. 18:227. (1880). 
the Rocky Mountain $Y$. glauca has been found in that region, the nearest approach being the Gulf plant here called $Y$. Louisianensis.

A few years since, Mr. James Gurney, Head Gardener of the Missouri Botanical Garden, was struck with the variety of foliage and difference in vigor of growth shown by the soap plants of Seward County, in extreme southwestern. Kansas, and he selected for the Garden and for Tower Grove Park a considerable number of plants to show the differences. Some of these plants, which have made a remarkably rapid growth, have now come into bloom. They differ considerably both as to their tendency to form a short trunk and in breadth and flexibility of foliage, though in this latter respect coming within the known range of variation of $\boldsymbol{Y}$. glauca, and to an equal extent in inflorescence, the variation in the two characters, however, not appearing capable of connection. While some of the plants produce a simple inflorescence, indistinguishable from that of $Y$. glauca, others almost exactly match the original figure of $Y$. stricta, and still others, with the same compound inflorescence, have the branches originating at about the top of the leaves instead of in the leaf-cluster. There seems to be little doubt that these plants represent the true stricta of Sims, and that the Atlantic States locality assigned to this when it was published rests upon some sort of error. Although, as has been said, the cultivated plants produce either simple or branched inflorescence, the prevalence of the latter in those which are strongly developed, and the rareness of branching in. the usual form of $\boldsymbol{Y}$. glauca, make it desirable to recognize this form varietally.

\section{Y. Arkansana Trelease.}

Y. angustifolia mollis Engelmann, Trans. Acad. St. Louis. 3 : 50, 51. (1873). - Watson, Proc. Amer. Acad. 14 : 253.

Y. glauca mollis Branner \& Coville, Ann. Rept. Geol. Surv. Arkansas for $1888.4: 224$. 
Y. stricta Baker, Gard. Chron. 1870: 923. - Hemsley, Garden. $8: 132$. - As to herbarium citations, in part.

T. angustifolia stricta Baker, Journ. Linn. Soc. Bot. 18:227. - As to herbarium citations, in part.

Y. glauca stricta Trelease, Rept. Mo. Bot. Gard. 4:206. pl. 22. Coulter, Contr. U. S. Natl. Herb. 2 : 437.

Y. recurvifolia ? Nutt. Trans. Amer. Philos. Soc. 5: 156.

Aspect and foliage of $Y$. tenuistyla. Inflorescence about $1 \mathrm{~m}$. high, racemose or very rarely with a few branches, glabrous. Flowers with mostly greenish-white broad and obtuse segments: style green, usually very tumid below. Capsule little flaring, smooth: seeds dull, 7 to $8 \times 10 \mathrm{~mm}$. - Plates $30.31 .83, f .7$.

From about Catoosa, I. T. (Bush, 1278) and Little Rock, Ark. (Engelmann, May 1837) to the vicinity of San Antonio, Tex.-Plate 88, $f$. 2.

The specific name Arkansana, here used, is applied in deference to the prevalent American practice in nomenclature, Engelmann's varietal name mollis (1873) having been similarly used under $Y$. gloriosa by Carrière, in 1860 .

33. Inflorescence amply panicled on a long scape. Foliage of the preceding or wider.

\section{Y. Louisianensis Trelease.}

Y. filamentos $a$ Riddell, N. O. Med. \& Surg. Journ. 8:763. - Raflnesque, Fl. Ludovic. 18. - Gray, Manual. [6 ed.]. 524. - Britton, Manual. 269.-As to the Louisiana citation.

$\boldsymbol{Y}$. stricta, $\boldsymbol{Y}$. stricta elatior, and $Y$. stricta intermedia Carrière, Rev. Hort. 1859 : $390,466 . f .101-2$.

Of the aspect of the preceding, or, when the inner leaves are dilated, of $Y$. filamentosa media. The flaccid green leaves 10 to exceptionally $40 \mathrm{~mm}$. wide, white bordered sparingly fliferous. Inflorescence an exserted glabrous or mostly pubescent panicle. Petals broad to attenuate. Style variously tumid and deep green, to pale and oblong. Capsule stout and short, angular in developing, as in $Y$. flaccida: seeds 6 to $7 \times 6$ to $10 \mathrm{~mm}$. - Plates $32-34.83$, f. 8 .

Louisiana (Alexandria, Ball 558; Minden and Alden Bridge, Trelease) to northern Texas (Jefferson, Trelease; Dallas, Reverchon; Texarkana, Trelease) and southeastern Indian Territory (Atoka, Butler; Standley, Ferriss; Poteau, Trelease). - Plate 92, f. 1 .

Apparently a western derivation of the same stock as the 
eastern $Y$. filamentosa and $Y$. flaccida, to both of which it bears some relationship, while apparently distinct from either. At Dallas, where Mr. Reverchon has long cultivated this and $Y$. rupicola, spontaneous hybrids occur, with the leaf-margin neither denticulate nor filiferous.

11. Leaves not fliferous, with a distinct thin horny, flnely denticulate border.

2. Capsule mucronate, with flat-backed valves.

Y. rigida (Engelmann) Trelease.

Y. rupicola rigida Engelmann, Trans. Acad. St. Louis. 3 : 49. (1873).-

Watson, Proc. Amer. Acad. 14 : 253. - Baker, Journ. Linn. Soc.

Bot. 18 : 223.

Caulescent, reaching a helght of 3 to $5 \mathrm{~m}$., simple or elongately fewbranched above. Leaves glaucous, thin but rather rigidly spreading, about $25 \mathrm{~mm}$. wide, mostly concave, often with scabrid ridges, slendertipped but very pungent, the yellow margin minutely denticulale. Inflorescence rather large, panicled close to the branches, glabrous. Flowers not very large. Capsule oblong, thick-walled, rough, not constricted, the flat valves tipped with short outcurved points: seeds very dull, 4 to 5 $\times 5$ to $6 \mathrm{~mm}$. - Plates 35. 36,f. 1. 84, f. 1 .

Mexico, from central Chihuahua to eastern Durango. Plate 93, f. 2.

The Engelmann herbarium contains two specimens (nos. A. and 477) of a Yucca collected in 1847 by Dr. Gregg, in a dry valley between Mapimi and Guajuquilla, in northern Mexico, which he noted as from 5 to 10 feet high, and which possesses glaucous denticulate-margined rather narrow leaves which in the herbarium appear quite rigid. In revising the Yuccas, Dr. Engelmann, recognizing a certain comparability of these specimens with $Y$. rupicola, designated them by the varietal name rigida, under that species, evidently mistaking Gregg's note on the height of the plants for that of the scape, instead of the trunk, which it really appears to have referred to. Within recent years, the same plant has been collected (and sometimes referred to this variety) by Wilkinson (134715, 224209), Rae and Hough (4220), and Pringle (165) in the Santa Eulalia mountains, near the city of Chihuahua. 
South of Torreon, along the Mexican Central railroad, particularly from about Pieardías to about Jalisco, this small tree is abundant, on or near the rocky hillsides, and conspieuously contrasted with accompanying $Y$. Treculeana by its very glaucous narrower foliage. It may be that small trees between Monterey and Saltillo, visible from the Mexican National railroad, extend its range to the east.

Yucca rigida, the specific name of which is descriptive only when its dried leaves are compared with those of $Y$. mipicola, is one of the handsomest tree Yuccas, in its foliage. The slender trunks are commonly simple, but occasionally once or more forked, with elongate branches. When well developed the leaves are from .3 to .6 m. long, 20 to 30 $\mathrm{mm}$. wide, and, as would scarcely be inferred from herbarium material, decidedly concave up to the very slender pungent terete point; both surfaces are closely ridged and often minutely roughened, and the bright yellow margin, though occasionally nearly smooth, is usually finely denticulate, so as to possess a keen cutting power. Though, as has been said, the plant forms a low tree when developed, a few specimens have been seen bearing panicles when still practically acaulescent, as is also true of $\boldsymbol{Y}$. radiosa about El Paso. The panicles are loosely branched shortly above the crown of leaves, and the very hard oblong capsules, about $50 \mathrm{~mm}$. long and $25 \mathrm{~mm}$. in diameter, are parted about to the middle into 3 valves which are conspicuously flattened or even concave on the back, and with short outcurved apical points, and the inner or placental dehiscence is very narrow, so that the small thin black seeds escape only when jarred out edgewise.

Dr. Engelmann would doubtless have given specific rank to this tree, had he not misapprehended its relation in size and field appearance to the typical acaulescent often twistedleaved $Y$. rupicola, which, in contrast with it, he called varicty tortifolia. The foliage and capsular characters added above leave no room for question as to its specific distinctness from the latter. 
$Y$. $\times$ rigida Deleuil, described by M. André,** is a garden hybrid obtained from $Y$. gloriosa fertilized by $Y$. cornuta (which is considered to be a synonym of $Y$. Treculeana), and, as the name rigida, being preoccupied, cannot be retained for it, it may be named, after its originator, $Y . \times$ Deleuili, in case, as seems desirable for convenience of reference, it and other hybrids are to be designated by binomials.

Y. RUPICOLA Scheele, Linnaea. 23 : 143. (1850). - Lemaire, Ill. Hort. 13: 96. - Baker, Gard. Chron. 1870: 828. - Engelmann, Trans. Acad. St. Louis. 3: 48. - Garden. 1 : 161. - Watson, Proc. Amer. Acad. 14 : 253. — Baker, Journ. Linn. Soc. Bot. 18 : 222. - Coulter, Contr. U. S. Natl. Herb. 2 : 436. Bot. Mag. iii. 47. pl. 7172. - Reverchon, Gard. \& Forest. 6 : 64. — Rept. Mo. Bot. Gard. 3 : 163. $p l .51$.

Y. rupicola tortifolia Engelmann, 1. c.

Y. lutescens Carrière, Rev. Hort. 1858 : 579.

$\boldsymbol{Y}$. tortilis Hort.

$\boldsymbol{Y}$. contorta Hort.

Acaulescent. Leaves glaucous, pungent, firm or flaccidiy spreading, often twisted, .3 to $.5 \mathrm{~m}$. long, 25 to $30 \mathrm{~mm}$. wide, the yellowish finely denticulate margin soon turning brown. Inflorescence glabrons, panicled mostly above the leaves. Flowers white or greenish: style white or greenish, oblong, often 3-sided. Capsule thin-walled, with flat or concave mucronate valves: seeds rather dull, 5 to $6 \times 7$ to $9 \mathrm{~mm}$. - Plates 37-39. 84, f. 2.

South-central Texas, from Tarrant County southwestward to and probably across the boundary.-Plate $93, f .2$.

One of the early discoveries of Lindheimer (1845), and Trécul (1848-9), sufficiently distinct from all of its congeners. Dr. Engelmann designated it as a.tortifolia, to distinguish it from his $\beta$. rigid $a$, spoken of above, with the statement that it is cultivated under the two garden names given in the synonymy.

* Revue Horticole. 55 : 110. (1883). 67: 81. (1895). 
In speaking of $Y$. rupicola and what he called its variety rigida, Dr. Engelmann* refers to intermediate specimens collected by Wright in " Eastern New Mexico" (no. 1909). The leaves of this number in the Torrey herbarium (Plate 37), it is true, are very hard to distinguish from narrower herbarium leaves of $Y$. rigida, but the corresponding sheet in the Gray herbarium (Plate 38) clearly represents a crown of the acaulescent $Y$. vupicola with inner leaves, - narrower and less twisted than the outer leaves probably were. A similar intermediate specimen in the Engelmann herbarium, collected by Wright in April or May 1850, on "Hills of the Blanco" is from the region of and accompanied by unmistakable, though detached, leaves of $Y$. rupicola, to which I should refer all of these specimens.

22. Capsule attenuate-beaked, with round-backed valves.

Y. rostrata Engelmann, in herb.

Of the aspect of $Y$. radiosa. Caulescent, at length $3 \mathrm{~m}$. high, simple or short-branched at the crown. Leaves very numerous, rigidly divergent, scarcely $10 \mathrm{~mm}$. wide, a little glaucous, flat or biconvex, striate, thin, very pungent, the yellow margin minutely denticulate. Inflorescence ample, with subincluded base or mostly exserted, glabrous. Flowers white, umbonate at base: style white, attenuate. Capsule oblong-ovoid, thick-walled, with convex valves long-attennate and spreading above: seeds rather dull, 4 to $5 \times 6$ to $7 \mathrm{~mm}$. - Plates $36, f .2 .40-42.84, f .3$.

Northern Mexico, from northern Chihuahua to the Sabinas valley in eastern Coahuila. - Plate 93, $f$. 2.

In 1852, Dr. Bigelow, of the boundary survey, collected a Yucca with narrow denticulate leaves, somewhat resembling $Y$. rigida, at Bufatillo, said to be in a volcanic mountainous region near Presidio del Norte, and what may possibly have been the same thing on sand hills thirty miles below San Elizario, - both along the Rio Grande, - and on gravelly hills at Los Moros. In August, 1880, Dr. Edward Palmer collected leaves, capsules, and seeds of ap-

* Trans. Acad Sci. St. Louis. 3 : 50. 
parently the same thing at Monclova, in the State of Coahuila. To these latter, Dr. Engelmann attached the manuscript name $Y$. rostrata, descriptive of the long-attenuate apex of the fruit.

While passing between Eagle Pass and Monterey, in company with Professor Sargent and Mr. Canby, in March 1900, my attention was attracted by a narrow-leaved Yucca that was cultivated at C. P. Diaz and in station yards along the Mexican International railroad, and that was found forming a natural low forest about Peyotes, on the water-shed between the Rio Grande and Sabinas, where, on subsequent visits, in April and August, I was able to study it in detail.

Among Yuccas this is conspicuously loosely rooted in the soil, so that large plants are easily removed. The trunks vary in height from about $.3 \mathrm{~m}$. to an observed maximum of about $3 \mathrm{~m}$., the usual height being about $2 \mathrm{~m}$., and the wood is extremely soft and spongy. When the old leaves are removed, the diameter of the stem is usually .15 or $.2 \mathrm{~m}$. , and it is not dilated except where the roots start from the base. Older plants are sometimes branched at the top, but the branches remain short, so that these trees usually possess several subapical crowns of leaves, rather than a series of separated elongated branches, like those of many other arborescent species.

The leaves are very numerous, radiating in every direction from the top of the stem in an oblong or usually nearly globose crown some 1.25 to $2 \mathrm{~m}$. in diameter, and, although thin, they are sufficiently rigid rarely to becomearched from their own weight, as they are in the species of Nolina, like $N$. longifolia, with similar foliage. They are flattened or a little biconvex, quickly contracted from a broad base and then very narrowly lanceolate, measuring about $6 \mathrm{~mm}$. at the narrowest point and $12 \mathrm{~mm}$. at the widest, which is about onethird their length below the grooved, acute, pungent apex. They are somewhat glaucous, occasionally slightly twisted 
and striately veined, and with a very narrow bright yellow horny margin that bears numerous very minute teeth, like those of $Y$. rupicola and $Y$.rigida. The old leaves, closely reflexed against the stem, persist for many years as a strawcolored thateh-like covering, and the denuded lower stem is lozenge-marked by the leaf-scars and does not develop a thick bark.

The glabrous panicle ranges from $.5 \mathrm{~m}$. long to more than twice that length, and is raised on a stalk 30 to $50 \mathrm{~mm}$. thick, which, though sometimes barely protruding from the leaves, is more commonly exserted for a length about equal to that of the branched part, and is sparingly bracteate, the narrow green lower bracts gradually passing into the dingy floral bracts. The common outline of the flower-cluster is attenuate-ovoid, but not infrequently the lower part of the cluster, like the top, is unbranched, the uppermost and lowest flowers then standing in the axils of the bracts of the main stem.

The rather large waxen pendent white flowers, which are very rarely somewhat purple-tinged, expand from 50 to 75 $\mathrm{mm}$. They are slightly umbonate at base, on short curved pedicels which rarely reach their own length. The segments of the perianth are lance-obovate, the inner whorl somewhat crenulate, and the outer narrower, thicker and subentire. The stamens, which are somewhat clavately thickened and spreading near the top, are coarsely papillate-pubescent, as in other species of the genus. The narrowly oblong conical ovary is green, and the attenuate white style considerably surpasses the stamens and ends in three slightly notched lobes.

The erect or suberect very firm-walled capsule, measuring about $25 \times 50 \mathrm{~mm}$., is oblong-acuminate with the attenuate upper thiri of the convex carpels somewhat spreading in dehiscence, and is raised on a concavely obconical base, corresponding to that noted for the flowers, from the top of which remnants of the withered perianth commonly de- 
pend. The seeds are black, thin, margined, and rather small.

Of somewhat the aspect of $Y$. radiosa, but with more rigid and denticulate not filiferous leaves, this species rivals in gracefulness of habit the Nolinas of Mexico and the grass-trees (Xanthorrhoea) of the South Sea, both of which it far surpasses in beauty of inflorescence, and it should prove a desirable addition to regions like California, Madeira and the Mediterranean countries, where it will prove hardy, and to some of the gardens of which $I$ have been able to send viable seed.

AA. Fruit indehiscent (so far as known).

B. Fruit soon drying, erect, spreading or pendent. Seeds thin, flat, slightly margined: albumen not ruminated (but surface of seed often somewhat grooved). - \$ Heteroyucca.

1. Leaves finely denticulate, softly green-pointed. Large tree.

Y. gigantea Lemaire, Ill. Hort. 6. Misc. 91. (Nov. 1859). 13: 92 . - Rev. Hort. 1860 : 222. — Engelmann, Trans. Acad. St. Louis. 3 : 212. - Baker, Gard. Chron. 1870: 1184. Journ. Linn. Soc. Bot. 18 : 224. - Hemsley, Garden. 8: 134. - Trelease, Rept. Mo. Bot. Gard. 9 : 141. $p l$. 40-42.

At length a rough-barked branching tree $10 \mathrm{~m}$. or more high. Leaves rigidly spreading or somewhat flexuous, green, glossy, plicate, with soft green tip, over $1 \mathrm{~m}$. long and often $100 \mathrm{~mm}$. wide, scabrid margined. Inflorescence compact, close to the leaves. Flowers resembling those of Y. gloriosa. Fruit apparently soon drying.

This species, if more than a form of $Y$. elephantipes, was first described from young specimens cultivated in European gardens, and again, in mature form, from a large tree cultivated in the Azores. It does not appear to be known in a state of nature. In habit and folinge, except for larger dimensions, it resembles $Y$. elephantipes, but if the notes on the spontaneous Azorean fruit are accurate, possesses fruit comparable with that of $Y$. gloriosa, and it may be a hybrid, $Y$. elephantipes being doubtless one parent, in this case; but it is very doubtful as anything but a form of $Y$. elephantipes. 
11. Leaves at most sparingly denticulate or flliferous, pungent. Lower plants.

2. Leaves broad, rigidly ascending or spreading.

Y. Gloriosa Linnaeus, Sp. Pl. 319. (1753). - Walter, Fl. Carol. 124. - Michaux, Fl. 1:196. - Duhamel, Arbres et Arbustes. 3. $p l$. 35. - Bryant, Flora Diaetetica. '16. - Pursh, Fl. 1 : 228. - Elliott, Bot. S. C. \& Ga. 1: 400. - Baker, Gard. Chron. 1870 : 1184. - Engelmann, Trans. Acad. St. Louis. 3 : 38, 211, 213. Koch, Dendrologie. $\mathbf{2}^{2}: 343$. - Carrière, Rev. Hort. 49: 287. f. 48. - Watson, Proc. Amer. Acad. 14 : 251. - Baker, Journ. Linn. Soc. Bot. 18 : 225 . Sargent, Silva. 10: 23. pl. 503. — Gard. Chron. iii. $28: 262 . f .77$. - Garden. $49: 218 . f$.

Y. acuminata Sweet, Brit. Fl. Gard. 2. pl. 195. (1827).-Bommer, Journ. d'Hort. Prat. 1859 : 42. - Lemaire, Ill. Hort. 13 : 95 . Baker, Gard. Chron. 1870:1123. Ref. Bot. 5. pl. 316.-Engelmann, Trans, Acad. St. Louis. 3:40.-Garden. 8:133. - Gard. Chron. n. s. $4: 110$.

Y. gloriosa acuminata Carrière, Rev. Hort. 1865 : 157. - Baker, Journ. Linn. Soc. Bot. $18: 226$.

Y. integerrima Stokes, Bot. Mat. Med. 2 : 267. (1812).

Tuca, sive Iucca Perana. Gerarde, Herball. 1359. $f$. (1597).

Iuca foliis Aloes. Bauhin, Pinax. 91. (1623, 1671).-Morison, Plant. Hist. 2 : 419. Sect. 4. pl. 23. (1680). - Pontedera, Anthologia. 295. pl. 6.f. n. (1720).

Yuca sive Iucca. Parkinson, Paradisus Terrestris. 434. f. (1629).

Yucca, sive Iucca Peruana. Johnson in Gerarde, Herball. 1543. $f$. (1636). - Raius, Hist. Plant. 2 : 1201. (1688).

Juca gloriosa. Munting, Waare Oeff. der Pl. 471. pl. (1682). - Naauwkeur. Beschryv. der Aardgew. 663. (1696.)

Yucca; foliis Aloës. Boerhaave, Index Alter Pl. Hort. Lugd.-Bat. 2: 132. (1720, 1727).

Cordyline foliis pungentibus integerrimis. Van Royen, Fl. Leyd. Prod. 22. (1740).

Yucca foliis margine integerrimis. Linnaeus, Hort. Cliff. 130.(1737)

Hort. Ups. 88. (1748).

Shortly caulescent and cespitose or the trunk 3 to $5 \mathrm{~m}$. high and with several branches. Leaves slightly glaucous when young, smooth or the dorsal lines roughened, rather thin but rigid, often concave near the inrolled purfgent usually dark apex, about.5 m. long and $50 \mathrm{~mm}$. wide, the 
usually brown margin at first with a very few distant rarely persistent minute teeth, when developed entire or occasionally with a few detaching slender fibers. Inflorescence mostly narrowly paniculate, the base often not exserted, glabrous or exceptionally puberulent. Flowers creamy white, often tinged with red or vlolet: ovary often with a slight suggestion of basal stipe; style oblong, white, frequently 3-divided. Fruit obovoid-oblong, mostly pendent, with six prominent ridges, the thin exocarp soon drying about the core: seeds glossy, 5 to $6 \times 6$ to 7 $\mathrm{mm}$., slightly grooved as if the albumen were ruminated.-Plates 43-46. $80, f .4$.

Coast and " sea islands," from South Carolina to northeastern Florida, on the sand dunes. Generally planted and in places escaping, in the eastern Gulf region.-Plate 94, f. 1 .

The typical form and what is called here variety plicata are the only spontaneous forms of this species of which I have knowledge. It has been in cultivation since 1596 (Gerarde, Herball, 1359.f.), and to-day is represented by a considerable number of garden forms, several of them hardy further North than any other species except $Y$. flaccida, $Y$. filamentosa, and $Y$. glauca. Some of these approach the following two species while others, scarcely presenting mature characters, are but tentatively placed anywhere; and a number of imperfectly described garden hybrids add to the difficulty of properly understanding Y.gloriosa. The following key, including these hybrids, may serve for the naming of the forms:-

Leaves not or little plicate, usually concave only toward the end.

Leaves rigidly spreading.

From slightly glaucous becoming green, .4 to $.8 \mathrm{~m}$. long, 40 to $50 \mathrm{~mm}$. wide.

Dwarf and smaller-leaved.

Y. gloriosa.

ore persistently glaucous.

More persistently glaucou
Somewhat falcate.

f. minor.

With whitish median variegation.

Outer leaves somewhat recurving.

Leaves but transiently glaucous.

Persistently glaucous.

f. obliqua.

f. medio-striata.

Leaves narrower.

var. robusta.

f. nobilis.

f. longifolia. 
Leaves conspicuously plicate toward the end, mostly very concave, not recurved.

Rather persistently glaucous.

Tall ( 1.5 to $3 \mathrm{~m}$.) Leaves at last greener.

Leaves dark green, persistently denticulate.

var. plicata.

Leaves purplish.

Leaves greener, very broad.

Leaves olive-green, scarcely pungent.

f. superba.

f. maculata.

Y. $\times$ Deleuili.

Y. X sulcata.

Y. $\times$ Carrierei.

Y. GLoRiosa Linnaeus.

Synonymy as above.

Acaulescent or not tall. Leaves broad, entire, green, neither recurved nor plicate, plane or very openly concave. - Plates 43.44.

The most common form of the Sea Islands of South Carolina and Georgia.

Y. GloRiosa minor Carrière, Rev. Hort. 1860 : 361. Truffaut, Rev. Hort. 1869 : 474. - Baker, Ref. Bot. 5. $p l$. 319. Journ. Linn. Soc. Bot. 18 : 225.

? Y. acuminata Garden. $27: 266 . f$.

Y. rubra Hort.

A garden form, smaller in every way. - Plate 45 .

Y. gloniosa obliqua (Haworth) Baker, Gard. Chron. 1870 : 1184 . Journ. Linn. Soc. Bot. 18 : 225.

Y. obliqua Haworth, Syn. Pl. Succ. 69. (1812). - Lemaire, Ill. Hort. 13 : 95 . - Engelmann, Trans. Acad. St. Louis. 3 : 40. - Koch, Dendrol. $2^{2}: 345$.

A form with glaucous leaves somewhat twisted to one side.

Y. gloriosa medio-striata Planchon, Fl. des Serres. 23. pl. 2393-4. (1880). - Gard. Chron. n. s. 13 : 716. Belg. Hort. 31 : 36. — Wiener Ill. Gart.-Zeit. $6: 156$.

Y. gloriosa medio-picta Carrière, Rev. Hort. 1880 : 259.

A garden sport with a median whitish stripe on the leaves.

Y. gloriosa robusta Carrière, Rev. Hort. 1868. 158.

? $Y$. acutifolia Truffaut, Rev. Hort. 1869 : 320. -Belg. Hort. 1870 : 24.

Y. gloriosa recurvata Baker, Gard. Chron. 1870 : 1184 .

Y. gloriosa Gawler, Bot. Mag. 31. pl. 1260 - - Redouté, Liliacées. 6. pl. 326-7. 
Intermediate between $Y$. gloriosa and $Y$. recurvifolia, with the outermost of the evanescently glancous usually slightly plicate leaves somewhat stiffly recurved.

$Y$. gloRIOSA NobIlis Carrière, Rev. Hort. 1860 : 360.1868 : 157.

Y. Ellacombei Baker, Ref. Bot. 5. pl. 317. (1872).-Engelmann, Trans. Acad. St. Louis. 3 : 41. - Garden. 4: 356. 8: 134, 147. 16 : 196, 214, 216, 236, 257, 285. — Gard. Chron. iii. 2 : 111.

Y. gloriosa Ellacombei Baker, Journ. Linn. Soc. Bot. 18 : 226. (1880).

$Y$. gloriosa Gardening Ill. $22: 155$. $f$.

Leaves scarcely plicate, glaucous, the outer recurved, sometimes twisted to one side.

An intermediate form, differing from f. robusta in its more persistently glaucous leaves. M. Carrière (Rev. Hort. $1860: 361$ ) recognizes a sub-variety parviflora of this variety.

Y. gloriosa longrfolia Carrière, Rev. Hort. 1862 : 234.

Y. longifolia Hort. in part.

Y. glaucescens Rev. Hort. 1:266. 2: 111. - Baker, Kew Bull. 1892 : 8.

Y. gloriosa glaucescens Carrière, Rev: Hort. 1860 : 360. - Baker, Gard. Chron. 1870 : 1184.

? Y. Brasiliensis Baker, Kew Bull. 1892 : 8.

Scarcely differs from var. nobilis except in its leaves when young being narrower, though in age they are said to reach a width of $75 \mathrm{~mm}$.

Y. gloriosa plicata Carrière, Rev. Hort. 1860 : 359 . Engelmann, Trans. Acad. St. Louis. 3 : 39, 40. Baker, Journ. Linn. Soc. Bot. 18 : 225.

Y. gloriosa Maund, Bot. Gard. 3. no. 286. - Elliott, Bot. S. C. \& Ga. 1 : 400. — Lemaire, Ill. Hort. 13 : 94. — Garden. 31 : 161 . f. 45 : 45.

f. $49: 332$. f. - Gard. Chron. n. s. $19: 820$. f. 137 . iii. $8: 692$. $f$. 136. iii. 15: 304. $p l .-$ Amer. Florist. 8: 61. f. - Rept. Mo. Bot. Gard. 3. $p l$. 6. - Gardiner, Journ. of Hort. 52 : 487, f. 126.

Y. plicata Hort.

Г. plicata glauca Hort.

Y. plicatilis Hort.

Y. glauca Hort., in part.

Differs from the type in having the more permanently glaucous usually shorter and hence relatively broader concave leaves evidently plicate toward the apex. 
"Sea islands" of Georgia and South Carolina, with the type.

Y. Gloriosa superba (Haworth) Baker, Gard. Chron. 1870 : 1184. Journ. Linn. Soc. Bot. 18 : 225. — Ellacombe, Garden. 8 : 147 .

Y. superba Haworth, Suppl. 36. (1819). - Bot. Register. 20. $p l$. 1690. - Lemaire, Ill. Hort. 13 : 94 . - Engelmann, Trans. Acad. St. Louis. 3 : 41. - Ellacombe, Gard. Chron. ili. 2 : 111.

Y. gloriosa Gard. Chron. n. s. 12 : 500, 688. f. 118. - Rept. Mo. Bot. Gard. 3. $p l$. 7. - Garden. $33: 202, f$. 58:446. $f$.

A cultivated form of var. plicata, becoming 3 or $4 \mathrm{~m}$. high, with greener leaves. - Plates $46, f .1$. $84, f .4$.

Y. gloriosa maculata Carrière, Rev. Hort. 1859 : 389 , 430. - Koeh, Dendrol. $\mathbf{2}^{2}: 345$.

A low garden form, with the plicate dark green leaves persistently a little roughened on the margin: the varietal name referring to a mottled variation of the usual red tinging of the flowers.

22. Leaves more elongated, recurved.

Y. Recurvifolia Salisbury, Parad. Lond. pl. 31. (1806).Nuttall, Gen. 1 : 218. — Pursh, Fl. 1 : 228. — Elliott, Bot. S. C. \& Ga. 1 : 401. - Lemaire, Ill. Hort. 13 : 94. - Curtis, Bot. N. Car. 56. - Baker, Gard. Chron. 1870:1184. Ref. Bot. 5.pl. 321.-Hemsley, Garden. 8 : 133, 136. f.-Koch, Dendrol. $\mathbf{2}^{2}: 344$. Gardiner, Journ. of Hort. $42: 246 . f$.

1. gloriosa recurvifolia Engelmann, Trans. Acad. St. Louis. 3 : 39, 40 . (1873). - Baker, Journ. Linn. Soc. Bot. 18 : 225 . - Amer. Garden. $11: 661,666 . f$.

Y. recurva Haworth, Syn. Pl. Succ. 69. (1812). - Gard. Chron. n. s. 18 : 689 . — Garden. 16 : 528. $47: 337$. $f$. - Gardening Ill. $18: 230 . f$. $22: 485 . f$.

Y. obliqua Regel, Gartenflora. 8 : 36. $17: 161 . p l .580$.

$\boldsymbol{Y}$. pendula Groenland, Rev. Hort. 1858 : 433. f. 128. - Carrière, Rev. Hort. 1859:488. f. 104. - Annales d'Hort. et de Bot. 2:93. Baker, Kew Bull. 1892 : 8. - Garden. 1 : 238. $f$.

Y. gloriosa Riddell, N. O. Med \& Surg. Journ. 8:763. - Lloyd \& Tracy, Bull. Torr. Bot. Cl. 28 : 71, 91.

Y. gloriosa mollis Carrière, Rev. Hort. 1860:362. - Baker, Gard. Chron. 1870 : 1184. 
Y. gloriosa planifolia Engelm. Trans. Acad. St. Louis. 3 : 39, 41.(1873).

$Y$. flamentosa variegata Park \& Cemetery. 11 : $184 . f$.

$Y$. variafolia Garden. 16:257.

Shortly canlescent, branching. Leaves at flrst somewhat glaucous, nearly plane, long, flexible, recurved, about $50 \mathrm{~mm}$. wide, often slightly plicate above, narrowly yellow- or brown-margined, often with a very few microscopic teeth, at length entire or slightly fllferous. Panicle narrow, the scape often inclnded. Styles shouldered. Fruit erect, oblong, with 6 winged ribs mostly infolded over the nectarial grooves: seeds rather dull, 6 to $7 \times 7$ to $8 \mathrm{~mm}$., the surface less grooved. - Plates 46. 47. 84, f. 5 .

"Sea islands" and adjacent coast of Georgia, and on Dauphin, Ship and Breton islands, between the mouth of the Mobile and the mouth of the Mississippi river. - Plate $94, f .2$.

This species appears to have been in cultivation since 1794, and, like the preceding, is represented by many garden varieties, among which some of the described hybrids already referred to are placed in the following key :-

Leaves neither variegated nor very broadly margined.

Bracts blackish- or purplish-brown.

Leaves dark green, $75 \mathrm{~mm}$. broad.

Leaves with conspicuous brown margin.

Leaves variegated.

With broad yellow margin.

With median yellow band.

With median reddish stripe.

Short and broad with pale or purplish stripes.
Y. recurvifolia.

f. tristis.

Y. X Andreana.

f. rufocincta.

f. marginata.

f. variegata.

f. elegans.

Y.X dracaenoides.

Y. RECURVIFOLIA Salisbury.

Synonymy as above.

Leaves soon becoming dark green, greatly elongated, very much recurved. - Plates $46, f .2 .47, f .1 .84, f .5$.

The usual wild form.

Y. recurvifolia tristis (Carrière) Trelease.

Y. gloriosa tristis Carriere, Rev. Hort. 1860 : 303. - Koch, Dendrol. $2^{2}: 345$.

A form with blackish-purple bracts. 
Y. Recurvifolia rufocincta Baker, Gard. Chron. 1870 : 1184.

Y. mufocincta Haworth, Suppl. 37.(1819).—Regel, Gartenflora. 8 : 37. Lemaire, Ill. Hort. 13: 95. - Engelmann, Trans. Acad. St. Louis. $3: 41$.

Y. gloriosa rufocincta Baker, Journ. Linn. Soc. Bot. 18 : 225. (1880).

A low form with rather pronounced accentuation of the reddishbrown margin.

Y. recurvifolia marginata (Carrière) Trelease.

Y. gloriosa marginata Carrière, Rev. Hort. 1880 : 259.

$\boldsymbol{Y}$. gloriosa marginata aurea Carrière, 1. c. 260.

Y. gloriosa elegans marginata Gard. Chron. n. s. 10:667. (1878).Wiener Ill. Gart.-Zeit. 5 : 76.

Leaves bordered with yellow, and often also rosy tinted. Gardens.

Y. recurvifolia variegata (Carrière) Trelease.

Y. pendula variegata Carrière, Rev. Hort. 1875 : 400.

Y. gloriosa variegata Carrière, Rev. Hort. 1880:260. — Gard. Chron. 1873 : 6 . iii. $6: 276,305$.

Y. pendula aurea Carrière, Rev. Hort. 1877 : 249 . 1879 : 404.

? Y. recurva elegantissima, Wiener Ill. Gart.-Zeit. $5: 460$. (1880).

? Y. glaucescens variegata Hort.

A garden sport with median yellow stripe.

Y. recurvifolia elegans Trelease.

Y. gloriosa elegans variegata. Belg. Hort. 1880: 63. - Gard. Chron. n. s. $16: 439$.

Y. gloriosa variegata Belg. Hort. 1884 : 33.

Y. gloriosa recurvifolia, fol. var. Rodigas, Ill. Hort. 30:13. pl. 475 . (1883).

Differs in having the median stripe reddish.

Y. Flexilis Carrière, Rev. Hort. 1859: 398. $f$. 89. Horticulturist. 14:548. $f$.-Lemaire, Ill. Hort. 13 : 97. - Baker, Gard. Chron. 1870: 1183. Journ. Linn. Soc. Bot. 18 : 224. - Engelmann, Trans. Acad. St. Louis. 3 : 41. - Koch, Dendrol. $\mathbf{2}^{2}$ : 345. - Hemsley, Garden. 8:129, 134. $f$.

Y. Mexicana Hort., in part.

Shortly caulescent. Leaves mostly transiently glaucons, nearly plane, long, narrow (20 to $40 \mathrm{~mm}$.), little if at all plicate, occasionally a little 
persistently denticulate or flliferous, flexible, at least the outer recurved. Panicle loose, exserted on a long scape. Style somewhat shouldered. Fruit unknown.

A many-formed plant, apparently known only in gardens. - Plate 47, f. 2.

The principal forms and the comparable named hybrids may be separated as follows : -

Leaves plane or little concave, bright glossy green, recurved. $Y$. flexilis.

Taller ( 1 or 2 m.). Leaves pale green.

f. ensifolia.

Leaves somewhat falcate.

f. tortulata.

Leaves evidently fliferous in age.

Leaves glaucous, little recurved.

f. Hildrethi.

Leaves concave, pale green.

Onter leaves recurved.

Leaves all strict.

f. patens.

Leaves scarcely pungent.

Leaves pale-striate, flliferous.

f. semicylindrica.

f. Peacockii.

f. Boerhaavii.

Y. X striatula.

The following garden hybrids, with flexible leaves less than $25 \mathrm{~mm}$. wide, might be sought here: -

Leaves flat, entire.

?

$?$

Leaves flat, often denticulate.

Leaves very concave.
Y. $\times$ Massiliensis.

Y. Xensifera.

Y. Xlaevigata.

$\boldsymbol{Y} \cdot \times$ juncea.

Y. Flexruis Carrière.

Synonymy as above.

Dwarf. Leaves long and narrow, loosely recurved, bright glossy green.

Known only in gardens, where, according to M. Carrière, it is sometimes erroneously called $Y$. acuminata, $Y$. stenophylla, $Y$. longifolia, and $Y$. angustifolia. It is also in part the $Y$. gloriosa of gardens.

\section{Y. flexilis Peacockii (Baker) Trelease.}

Y. Peacockii Baker, Journ. Linn. Soc. Bot. 18 : 223. (1880). Kew Bull. 1892 : 8. - Wiener Ill. Gart.-Zeit. 6 : 320. - Garden. 19 : 226.

Scarcely appears to differ except in the numerous leaves being stricter. 
Y. Flexilis exsifolia (Groenland) Baker, Journ. Linn. Soc. Bot. 18 : 224. (1880).

Y. ensifolia Groenland, Rev. Hort. 185̃9 : 433. f. 129. - Baker, Gard. Chron. 1870: 217. Ref. Bot. 5. pl. 318. - Engelmann, Trans.

Acad. St. Louis. 3 : 41.- Hemsley, Garden. 8 : 134. $f$.

Y. Eylesii Hort.

Taller ( 1 to $1.5 \mathrm{~m}$.) with less recurving, soon pale green, somewhat concave, entire leaves.

\section{Y. flexilis Hildrethi Trelease.}

Differs from $\mathrm{f}$. ensifolia chiefly in having its frequently somewhat falcate leaves usually finely fliferous in age.-Plate $41, f .2$.

Cultivated, from unrecorded source, and escaped, at the place of Mr. J. A. Hildreth, at St. Augustine, Fla., where it is said to bloom through the winter and where the speccimen photographed was observed in flower at the end of May, simultaneously with $Y$. aloifolia, - though it has never been known to set fruit.

Y. flexilis tortulata (Baker) Trelease.

Y. tortulata Baker, Gard. Chron. 1870:1122. - Engelmann, Trans. Acad. St. Louis. 3 : 41. - Hemsley, Garden. 8 : 133.

Y. gloriosa tortulata Baker, Journ. Linn. Soc. Bot. 18 : 226. (1880).

Y. falcata Garden. 16:369. (1879).

Y. Alexilis falcata Baker, Journ. Linn. Soc. Bot. 18 : 224. (1880).

Y. undulata Hort., in part.

Differs from f. ensifolia chiefly in being shorter-stemmed and with the green leaves flatter and somewhat falcate, and from $Y$. gloriosa minor in its longer outer leaves being reflexed.

Y. Flexilis semicylindrica Baker, Journ. Linn. Soc. Bot. 18 : 224 . (1880).

Y. semicylindrica Baker, Gard. Chron. 1870: 1217.

Differs from $\mathrm{f}$. ensifolia in its firm and deeply concave narrower leaves (less than $20 \mathrm{~mm}$. wide).

Y. flexilis Boerhaavii (Baker) Trelease.

Y. Boerhaavii Baker, Gard. Chron. 1870:1217. Journ. Linn. Soc. Bot. 18 : 224. - Engelmann, Trans. Acad. St. Louis. $3: 41$.

Chiefly differs from the preceding in its flat scarcely pungent leaves. 
Y. flexilis patens (André) Trelease.

Y. patens André, IIl. Hort. 17:120. $f$. (1870).-Gard. Chron. 1871 : 412 .

Y. pruinosa Baker, Gard. Chron. 1870 : 1122. - Garden 8: 133.

Y. gloriosa pruinosa Baker, Journ. Linn. Soc. Bot. 18 : 226. (1880),

A garden form, said to have come from China, with less arched glaucous slightly rough-margined leaves: approaching some of the forms of $Y$. gloriosa.

$Y$. gloriosa, $Y$. recurvifolia, and $Y$. flexilis, - the last two of which have frequently been treated as forms or varieties of the first-named, present a number of interesting and suggestive peculiarities when studied comparatively.

$Y$. gloriosa occurs spontaneously among the sand dunes of a restricted portion of the southeastern Atlantic coast, where it is often intimately associated with $Y$. aloifolia and one or more forms of $Y$. filamentosa. Y. recurvifolia, except for one isolated group of stations, is known from a still more limited part of the same coast. $Y$. flexilis is known only in gardens, and its source appears to have been as unknown to its describer as it is to those who now cultivate it.

About these three so-called species, have clustered in horticultural literature a considerable number of cultivated forms, sometimes treated as varieties of one or the other and sometimes specifically named, all of them entire-leaved with the exception that the margin is more or less persistently a little roughened or denticulate or a little filiferous in several of them, and all, so far as I have observed records, flowering usually in late summer or later,- occasionally well on to the end of the season.

These forms are not infrequently aberrant when placed, from the appearance of a character usually present in some other of the three species than the one under which the given form goes on the general assemblage of its characters. This interblending of characters in some of the variants of plants so distinct in their typical forms as $Y$. gloriosa, $Y$. 
recurvifolia and $Y$. flexilis are, suggests the possibility that the connecting varieties may really be of hybrid origin. Opposed to this supposition, however, are the absence of any reeorded history of their source or origin; the fact that they have appeared in cultivation and are classed with plants likewise of garden origin or long cultivated and in their other forms giving evidence of considerable variability ; and, partieularly, the facts that, except for $Y$. aloifolia, the Yueeas spontaneously fruit with extreme rarity away from their native home unless, as seems not to be the case in European gardens where these forms have made their appearance, a moth (Pronuba yuccasella) upon which their pollination almost absolutely depends has been introduced with them, and that most persons who have tried to fertilize the plants of this genus have met with little or no suscess. Still, suggestion of such hybrid origin has been made, ${ }^{*}$ and the most positive proof is at hand that along the Mediterranean coast, at least, skilful operators can not only intercross these so-called species but can also hybridize them reciprocally with other very distinct species both of the baccate and capsular sections of the genus. Thus, for instance, M. Deleuil, of Marseilles, in and subsequent to 1874 , crossed $Y$. aloifolia variegata and $Y$. alba-spica (whatever that may be), $Y$. aloifolia variegata $q$ with $Y$. pendula (or recurvifolia), $Y$. plicata (or gloriosa plicata) ? with $Y$. angustifolia vera (or glauca), $Y$. plicata $q$ with $Y$. $\times$ laevigata (=aloifolia variegata $\times$ alba-spica), $Y . p l i$ cata q with $Y$. filamentosa, $Y$. plicata $q$ with $Y$. Treculeana, $Y$. cornuta (or Treculeana) $q$ with various species, $Y$. aloifolia variegata $q$ with $Y$. angustifolia vera, $Y$. gloriosa longifolia (or $Y$. flexilis glaucescens?) $q$ with various species, $Y . \times$ laevigata $q$ with $Y$. filamentos $a, Y$. cornuta and

* Ellacombe, for instance, supposed the $Y$. Ellacombei of gardens, which I take to be synonymous with $Y$. gloriosa nobilis, to be a probable cross between $Y$. recurvifolia and the garden form known as $Y$. gloriosa superba. - Garden. 16: 257 . 
$Y$. plicata, and $Y$. angustifolia vera $q$ and $Y$. Treculeana $q$ with various species; and $\mathrm{I}$ have knowledge that within recent years a very large series of reciprocal crosses have been effected by Mr. Carl Sprenger between these subentire-leaved forms as well as between them and both baccate and capsular species, and within the latter groups.* In Texas, also, spontaneous hybrids between $Y$. rupicola and $Y$. Louisianensis appear to occur.

Everything considered, therefore, the garden intermediates between $Y$.gloriosa, $Y$. recurvifolia and $Y$. flexilis may at least quite as properly be looked on as being the probable results of occasional unrecorded crossing between these forms as merely very aberrant sports. Few of them appear now procurable, but as far as a knowledge of them can be obtained from the brief descriptions, the known hybrids of M. Deleuil are capable of natural arrangement under one or the other of these so-called species.

With respect to the latter, themselves, the same line of inquiry suggests itself. The garden $Y$. flexilis, though in its typical form much narrower- and greener-leaved and with more elongately pedunculate and lax panicle, appears morphologically to represent only an extreme development of $Y$. recurvifolia, with which, except that it lends itself readily to the coordination of a number of forms in this respect comparable with those similarly grouped under $Y$.recurvifolia, it would logically be connected. The latter itself presents to the eye a blending of the characters of $Y$. glorios $a$ and $Y$. flaccida, which led one of the best students of woody plants, Koch, $\dagger$ to suggest some years since that it may be a hybrid between $Y$.gloriosa and $Y$. filamentosa, under which name he doubtless meant the recurved-leaved plant here called $Y$. flaccida. No greater reason exists for

* On the results reached by $M$. Deleuil see Revue Horticole. 52 : 226 . 55 : 109. 58 : 63. 67: $81, f .21-23$. - Gard. Chron. n. s. 13 : 807.

+ Dendrol. $2^{2}: 344$. 
the rejection of this supposition than in case of the similar one that intermediates between $Y$. gloriosa, $Y$. recurvifolia and $Y$. flexilis may be the results of various intercrossing, since the possibility of crossing $Y$. gloriosa and $Y$. flaccida has been demonstrated by some of the experiments referred to above; and M. Deleuil's selection of 150 very diverse seedlings from a single one of his crosses gives reason to suppose that on the one hand a number of different aberrants of these species might have come from even one cross seeding, while on the other hand several well verified hybridizations between $Y$. gloriosa and $Y$. flaccida might perhaps fail to produce typical recurvifolia. The occurrence of the latter along the South Atlantic coast of the United States, while it suggests the spontaneous hybrid origin of the typical form of this species, does not preclude the possibility that the same form, and particularly its aberrant varieties, may have originated by a comparable process in gardens, where, in fact, they are alone known at present.

Though $Y$.gloriosa and $Y$. filamentosa are typically very dissimilar in aspect as well as in technical characters, I have seen side by side on the sand dunes of Tybee Island, Georgia, an acaulescent plant of the spontaneous variety plicata of the former and a normal plant of the form of the latter known as var. concava, so similar in foliage appearance that it was only on close approach that the thinner texture and freely filiferous margin of the leaves of the latter served for its recognition, and I should be even more disposed to believe $Y$. gloriosa plicata a hybrid between $Y$. gloriosa and $Y$. filamentosa concava than to accept the suggestion of Koch concerning $Y$. recurvifolia.

As to $Y$. gloriosa, I have long thought that I saw in its characters somewhat of a blending of those of $Y$. filamentosa and $Y$.aloifolia, the leaves having something of the firmness and thickness of texture of the latter, and something of the thinness and concavity of the former or its variety, with 
frequent vestiges of the marginal characters of both; while in the color, shape and texture of the perianth, the slight stipe at base of the ovary, the sometimes rather short shouldered style, the mostly pendent indehiscent fruit with thin exocarp drying about a papery core, and the often venously grooved if not truly ruminated seeds, $Y$. gloriosa holds even more nearly the mean between the two species named.

The suggestion of a spontaneous hybrid origin of $Y$. gloriosa offered by this blending in it of the characters of the two other species with which it is most closely associated, would be less strong if $Y$.gloriosa behaved in general like a normal species of the genus, if it were of greater geographic distribution, or if it occurred in places thoroughly isolated from the assumed parents.

As has been said, though locally rather abundant, $Y$. gloriosa as a spontaneous plant is limited, so far as is now known, to a very restricted region about the Carolina and Georgia coast. It is, moreover, a very unusual species in its life processes. In the arid region of the Mexican table-land, the Yuccas are known to be largely dependent for their blooming season upon necessary rainfall, so that a given species, though usually fairly regular, may bloom in aberrant years at any time between midwinter and midsummer, and the Pronuba moth which serves as pollinator appears to show a similar susceptibility to moisture in the soil, and commonly emerges from the pupa state synchronously with the flowering of the Yuccas. $Y$. gloriosa, however, growing in a region where the other Yuccas bloom pretty regularly during a rather limited part of the spring, when the Pronuba flies, differs from these species in flowering usually in late summer and autumn, though exceptional flower clusters appear to be developed at almost any season of the year, and the only instances that I certainly know of in which its fruit has been observed were once when early blooming plants cultivated in Washington 
bore fruit,* once when Dr. Mellichamp found fruit on a plant which had bloomed simultaneously with $Y$. filamentosa, $\dagger$ and a third instance observed by me on Tybee Island in May last, (Plate $41, f .2$ ) on a plant which must have bloomed just about as $Y$. filamentosa was coming into flower. The species, therefore, is all but restricted for its propagation to vegetative methods, by which its present distribution along the sand dunes can fairly well be explained, since the well-budded thick subterranean shoots possess great vitality.

What has been said of the ecology of $Y$. gloriosa might be repeated almost verbatim for $Y$. recurvifolia, which is likewise autumnal-flowering, and the fruit of which, barring several rather questionable statements in gardening journals, - to my knowledge has never been observed until Dr. Mellichamp, in the summer of 1901 , found plants fruiting in cultivation in the neighborhood of Charleston, and furnished the material from which the description and illustration here published were drawn. The occurrence of $Y$. recurvifolia on several islands between the delta of the Mississippi and the mouth of the Mobile river, which is not connected with the present question, may, perhaps, have been brought about by currents transporting rhizome fragments derived from plants cultivated somewhere along one of the rivers opening on the northern shore of the Gulf.

These ecological considerations suggest with force that if species in the time-honored use of that term, $Y$. gloriosa and $Y$. recurvifolia, so far as their spontaneous forms are concerned, are of unexpectedly restricted distribution in a region where their congeners are widespread, and that they manifest a surprising disharmony with their surroundings which, because of the rigid pollination requirements of all of this genus but aloifolia, has thrown them into almost

* Engelmann, Trans. Acad. Sci. St. Louis. 3 : 211.

† Rept. Mo. Bot. Gard. 4 : 199. 
absolute dependence upon vegetative methods of propagation; though they continue to flower profusely, and because of the unusual if aberrant period over which their blooming extends they now and then fruit, and they are shown to be so fertile under skilful artificial pollination that there is little reason to doubt that they would fruit regularly if they bloomed when the Pronuba was about; - while over the great territory lying between the Atlantic and Pacific and the big bend of the Missouri river and central Mexico, the other Yuccas have held so close a relation with their pollinators as to be very fruitful under all ordinary circumstances. The ecological facts stated, however, are consistent with the morphological suggestion that $Y$. gloriosa may be a hybrid between $Y$. aloifolia and $Y$. filamentosa, and the two considerations appear to constitute so strong an argument for the acceptance of the a priori theory advanced, as to throw the burden of proof upon any who would still regard gloriosa as a species in the ordinary sense, - though for purposes of classification it, as well as recurvifolia and flexilis, may continue to be treated as species.*

222. Leaves crowded, regularly and rigidly arcuate.

Y. De Smetrana Baker, Gard. Chron. 1870 : 1217. Journ. Linn. Soc. Bot. 18 : 222. Kew Bull. 1892 : 8.

\section{? Y. Helkinsi Hort.}

Canlescent, at length with a trunk 2 or $3 \mathrm{~m}$. high. Leaves rigid, evenly and stiffly recurved, becoming .4 m. long and $25 \mathrm{~mm}$. or more wide, purple tinged, entire or slightly rough-margined at base, not pungent. Flowers and fruit unknown. - Plate 48.

A garden plant ascribed to Mexico, which when small is very suggestive in appearance of a lily because of its crowded arching not at all concave leaves: quite unlike any other $Y u c c a$, and perhaps not of this genus. No positive record exists of the source of the plants of this species cul-

* The substance of these conclusions was presented at the Denver meeting of the Botanical Society of America, in August 1901. 
tivated at the Missouri Botanical Garden, but they are believed to have come from northern Mexico, many years ago, through Dr. Parry.

B. B. Fruit pendent, fleshy and edible: seeds thick, often convex, nearly without a thin border; albumen evidently ruminated. - $\$$ Sarcoyucca.

1. Fruit coreless, purple-fleshed. Leaves with denticulate horny border.

Y. Alorfolia Linnaeus Sp. Plant. 319. (1753).- Walter, Fl. Carol. 124. - Michaux, Fl. 1 : 196. - Pursh, Fl. 1 : 228. - Nuttall, Gen. 1 : 218. - Riddell, N. O. Med. and Surg. Journ. 8 : 763. — De Candolle, Pl. Grasses. 1. $p l$. 20. - Redouté, Liliacées. 7. pl.401-2.-Sims, Bot. Mag. 40. pl. 1700.-Bommer, Journ. d'Hort. Prat. [ii]. 3:18._Lemaire, Ill. Hort. 13:92. Curtis, Bot. N. C. 56.-Baker, Gard. Chron. 1870 : 828 . Journ. Linn. Soc. Bot. $18: 221$. Kew Bull. 1892 : 7. - Engelmann, Trans. Acad. St. Louis. 3 : 34, 211. - Watson, Proc. Amer. Acad. 14 : 251 . Wood \& McCarthy, Journ. Elisha Mitchell Soc. 1885-6 : 125. - Trelease, Rept. Mo. Bot. Gard. 3 : 162. pl. 7, 44. 4:182. pl. 18. - Webber, Rept. Mo. Bot. Gard. 6:91. pl. 45-7. - Sargent, Silva. $10: 6 . p l$. 497. - Hemsley, Bot. Bermudas. 69.Kearney, Contr. U. S. Natl. Herb. $\mathbf{5}^{6}$. Index.

Y. aloifolia stenophylla Bommer, Journ. d'Hort. Prat. [ii]. 3 : 19. (1859).

Y. glorios $a$ Nuttall, Gen. 1 : 218. - Bartram, Travels. 69-70, and French ed. 1 : 139-142. — ? Chapman, West. Journ. Med. \& Surg.1845 : 480. — Rev. Hort. 58: 508. - Eggers, Bull. U. S. Nat. Mus. 13: 109. Hemsley, Bot. Bermudas. 69.

Y. Draconis Elliott, Bot. S. C. \& Ga. 1 : 401.

Y. serrulata Haworth, Suppl. 32. (1819). - Regel, Gartenflora. 8 : 35. Lemaire, Ill. Hort. 13 : 93. - Engelmann, Trans. Acad. St. Louis. 3 : 37 . - Baker, Journ. Linn. Soc. Bot. 18 : 221.

Y. crenulata Haworth, Suppl. 33. (1819). - Lemaire, Ill. Hort. 13 : 93. Baker, Gard. Chron. 1870 : 828 . Journ. Linn. Soc. Bot. 18 : 221. Engelmann, Trans. Acad. St. Louis. 3 : 37.

? Y. armata Steudel, Nomencl. 2: 795. [ed. 2]. (1841.)

? Aloe Juccae foliis. Sloane, Cat. Pl. Jamaica. 118. (1696.)

Aloe Americana juccae foliis arborescens. Commelin, Praelud. Bot. 64. f. 14. (1703.) 
Aloes Floridana procerior. Plukenetius, Amalth. Bot. 10. (1705).

Aloe Yuccae foliis caulescens Floridana. Plukenetius, Amalth. Bot.

10. (1705). Almag. 19. pl. 256.f. 4. (1696, 1700).

Aloe; Americana; folio Yuccae; arborescens. Boerhaave, Index Alter

Plant. Hort. Lugd.- Bat. 2 : 131. (1720, 1727).

Yucca arborescens, foliis rigidioribus, rectis, serratis. Dillenius,

Hort. Elth. 2 : 435. pl. 323. (1732).

Yucca foliorum margine crenulato. a. Linnaens, Hort. Cliff. 130. (1737).

Cordyline foliis pungentibus crenulatis. Van Royen, Fl. Leyd. Prod.

22. (1740).

Low slender tree, somewhat short-branched above and often cespitosely suckering. Leaves flat, rather thick, rigid, denticnlate on the margin, very pungently brown-pointed. Inflorescence usually close to the leaves, compactly panicled. Flowers creamy, tinged with green or purple toward the base; ovary shortly stipitate; style short, not contracted, oblong or a little tumid, abruptly starting from the ovary. Fruit oblong-prismatic, nearly black, coreless, with dark purple pulp; seeds glossy, round or oval, often acute at one end, 5 or $6 \times 6$ or $7 \mathrm{~mm}$. Plates 49-50. 84, $f$. 6 .

Virgin Isles, Jamaica, eastern coast of Mexico (Vera Cruz), the Bermudas, Atlantic and Gulf States southward from about Pamlico Sound; and occasionally escaping from cultivation as far inland as Monroe in northwestern Louisiana. - Plate 95, f. 1.

The principal forms of this species, which has been cultivated in Europe since 1605 and which differs from all other Yuccas in its stipitate ovary and coreless purple-pulped fruit, commonly formed without Pronuba aid, may be distinguished as follows: -

Panicle glabrous.

Leaves rigid, ascending, usually 25 to $40 \mathrm{~mm}$. wide when developed. Green throughout.

Y. aloifolia.

Purplish tinged.

f. purpurea.

Yellow-margined.

f. marginata.

With yellow and white center, and often red variegation. f. tricolor.

Leaves recurving.

Leaves 40 to $50 \mathrm{~mm}$. wide. Stem tall.

Branching above.

var. Draconis.

Branching at base.

f. conspicua.

Leaves 10 to $20 \mathrm{~mm}$. wide. Stem low. 
Leaves smooth, little denticulate.

Leaves rough-margined.

Leaves with red and yellow central stripe. var. arcuata.

f. tenuifolia.

f. Menandi. Panicle tomentose. var. Yucatana.

\section{Y. Aloifolia Linnaeus.}

Synonymy as above.

Mostly simple, with slender trunk. Leaves not recurving, very rigid and pungent, green, often a little glaucous when young. - Plates 43.44 . so, f. 6 .

The common wild form, cultivated in Europe at least since 1696. According to Mr. Fawcett, though it grows near the Kingston gardens, at an elevation of $680 \mathrm{ft}$., it is more commonly found in Jamaica between 2,000 and 5,000 ft. above sea-level, whereas in the United States it is a seaside plant or of the coast lowlands, and never found far above sea-level.

Y. aloifolia PurPurea Baker, Journ. Linn. Soc. Bot. 18 : 221. (1880).

Y. Atkinsi Hort.

A purplish-leaved garden form, perhaps more properly placed under var. arcuata.

Y. aloifolia marginata Bommer, Journ. d'Hort. Prat. [ii]. $\mathbf{3}: 19$. (Jan. 1859).

Y. serrulata argenteo marginata Regel, Gartenflora. 8: 35. (Feb. 1859). Y. aloifolia variegata Naudin, Pl. Feuill. Col. 2. pl.52.(1870). - Gard.

Chron. n. s. 13 : 81 . 18: 407. - Meehan's Monthly. 9: 196. f. - Carrière, Rev. Hort. $50: 18,104$.

$\boldsymbol{Y}$. variegata Hort.

Y. aloefolia versicolor Carrière, Rev. Hort. 50 : 104. (1878).

Y. versicolor Carrière, Rev. Hort. 50 : 18. (1878).

A garden form with the leaves green at center, bordered and striped with various shades of yellow and white, and often tinged with red at least when young. No doubt separable into at least three forms capable of being flxed by selection:- one with yellow margin, one with added white stripes, and one with a fairly persistent additional line of red on the back near the border. 
Y. Aloifolia tricolor Bommer, Journ. d'Hort. Prat. [ii]. 3 : 19. (Jan. 1859).

? Y. aloifolia roseo-marginata Regel, Gartenflora. 8:35. (Feb. 1859).

Y. quadricolor Groenland, Rev. Hort. 1859 : 434. - Carrière, Rev. Hort. $50: 18,104$. $51: 404$.

Y. quadricolor variegata Carrière, Rev. Hort. 45: 405. (1873).

Y. medio-picta Carrière, Rev. Hort. 50:104. (1878).

? Y. picta Hovey, Garden. 11 : 208. (1877).

? Y. lineata lutea Hort.

? Y. Stokesi Garden. 12:134. (1877). 33 : 487.

Y. tricolor Baker, Journ. Linn. Soc. Bot. 18 : 221. (1880).

Y. aloifolia quadricolor Gard. Chron. n. s. 18 : 245. (1882).

A garden sport of the preceding with a median yellow or white band bordered with green, and likewise tinged with red when young.

Neither of these variegated forms comes true to seed, and the intensity of the variegation, particularly the red, is apt to change with age and season. Knowledge of the garden synonyms is so indefinite that some of those marked with a question may be wrongly placed, and what is called $f$. Menandi below may perhaps be identical with one of them.

Y. aloifolia Draconis (Linnaeus) Engelmann, Trans. Acad. St. Louis. 3:35. (1873).-Baker, Journ. Linn. Soc. Bot. 18 : 221.

Y. Draconis Linnaeus, Sp. Pl. 319. (1753). - ? Bot. Reg. 22. pt. 1894. - Lamarck, Encycl. Meth. 1. pl. 243. - Bommer, Journ. d'Hort. Prat. 3 : 40. - Baker, Gard. Chron. 1870 : 828. f. 154.Lemaire, Ill. Hort. 13 : 93.

Y. Haruckeriana Crantz, De duabus Draconis arb. bot. 29. (1768).

Y. Draco Carrière, Rev. Hort. 1859 : 389.

Tacori. Clusius, Exot. 48. (1605). - J. Bauhinus, Hist. Plant. 1 : 405. (1650).

Draconi arbori affinis, Americana. C. Bauhlnus, Pinax. 506. (1623, 1721).

? Aloe purpurea levis. Munting, Phytogr. Curios. 20. f. 94. (1702, 1713).

Aloe Americana Draconis follo serrato. Commelin, Praelud. Bot. 42, 67. f. 16. (1703).

Aloe; Americana; folio Draconis serrato. Boerhaave, Index Alter Plant. Hort. Lugd.-Bat. 2 : 129. (1720, 1727).

Yucca Draconis folio serrato, reflexo. Dillenius, Hort. Elth. 2 : 437. pl. 324. (1732). 
Yucca foliorum margine crenulato. $\beta$. Linnaeus, Hort. Cliff. 130. (1737). Hort. Ups. 88. (1748).

Trunk branching above, rather tall, leaves broad and long, more fiexible and somewhat arched, less pungent.

As far as it is known to me $Y$. Draconis, taking the figure of Dillenius as representative of it, is properly placed under $Y$. aloifolia, with the differential characters given. It appears to have been cultivated in Europe since 1605, but it is not impossible that much of the earlier Draconis, like that of gardens to-day, was the Central American Y. elephantipes, the fruit and flower characters of which are quite different from those of $Y$. aloifolia, though the foliage is of the same general type.

Y. aloifolia conspicua (Haworth) Engelmann. Trans. Acad. St. Louis. 3:35. (1873). - Baker, Journ. Linn. Soc. Bot. 18 : 221.

I. conspicua Haworth, Suppl. 32. (1819). - Lemaire, Ill. Hort. 13 : 92. - Houllet, Rev. Hort. 50 : 388.

I. aloifolia flexifolia Bommer, Journ. d'Hort. Prat. 3 : 19. (1859).

7. Mexicana Hort., in part.

Trunks clustered. Leaves broad and lax, recurving, softly green pointed.

A form of the preceding, frequent in European gardens and said by Baker to be represented by wild [escaped?] plants from the vicinity of Cuernavaca, on the Pacific slope of Mexico (Bourgeau, no. 1408).

Y. aloifolia areuata (Haworth) Trelease.

I. arcuata Haworth, Suppl. 33. (1819). - Regel, Gartenflora. 8 : 35. Lemaire, Ill. Hort. 13 : 93. - Baker, Gard. Chron. 1870: 828. Journ. Linn. Soc. Bot. 18:221, - Engelmann, Trans. Acad. St. Louis. 3: 37 .

Short-stemmed from a prostrate caudex. Leaves less than $25 \mathrm{~mm}$. wide, .3 to $.5 \mathrm{~m}$. long, smooth, the margins less denticulate than usual.

A garden form, doubtless derived from the Carolina coast region, and seemingly of shaded places. 
Y. aloifolia tenuifolia (Haworth) Trelease.

Y. tenuifolia Haworth, Suppl. 34. (1819). - Regel, Gartenflora. 8 : 35. Lemaire, Ill. Hort. 13 : 93. - Baker, Journ. Linn. Soc. Bot. 18 : 221. - Engelmann, Trans. Acad. St. Louis. 3 : 37.

Habit of the preceding, the leaves frequently faleate, often purplish, with somewhat roughened dorsal ridges and very sharp but fine marginal toothing.

A cultivated form, doubtless of the coast region, and found by the writer in April 1901 escaped along the shady roadside near the Grant-Pemberton monument at Vicksburg, Miss. - in which city, however, the usual cultivated plant is typical aloifolia.

\section{Y. aloifolia Menandi Trelease.}

A sport, seemingly of $f$. tricolor, with the rigidly much recurved leaves about $.3 \mathrm{~m}$. long, 5 to $10 \mathrm{~mm}$. wide, somewhat rough on both margin and dorsai ridges, of a deep green, with yeliow and occasionally red median band or lines narrow on the upper surface but, as in forma tricolor, occupying a large part of the lower surface. - Plate 50.

Purchased from Mr. W. A. Manda (from the Louis Menand collection) in July 1901, under the name $Y$. quadricolor.

\section{Y. aloifolia Yucatana (Engelmann) Trelease.}

Y. Yucatana Engeimann, Trans. Acad. St. Louis. 8 : 37 . (1873).-Baker, Journ. Linn. Soc. Bot. 18 : 221. - Trelease, Rept. Mo. Bot. Gard. 3: 162 . $p l .45$.

Trunks clustered from the base, as much as $7 \mathrm{~m}$. high. Leaves rather flexible. Inflorescence tomentose. Stamens shorter than in the type.

Yucatan, collected by Schott (706) in 1865 at the ruins of "Nohpat" or "Najput."

From all of the other baccate Yuccas, $Y$. aloifolia, in the comprehensive sense, differs obviously in its evidently stalked ovary and coreless purple-fleshed fruit. Its geographical distribution is such as to lead to the conclusion that it may have originated in the eastern islands of the West Indian group, from which it may have spread, by aid of ocean currents, to the Atlantic states and Bermudas, and, by way of Jamaica, to the Mexican coast, isolation 
on the peninsula of Yucatan having given opportunity for the differentiation of the marked varicty named after that country.

11. Fruit with papery core and white or yellow flesh.

2. Leaves very large and thin, minutely denticulate.

Y. Elephantipes Regel, Gartenflora. 8 : 35. (Feb. 1859).

Y. Guatemalensis Baker, Ref. Bot. 5 . pl. 313. (1872). Kew Bull. 1892 : 7. Journ. Linn. Soc. Bot. $18: 222$. - Engelmann, Trans. Acad. St. Louis. 3 : 38. - Trelease, Rept. Mo. Bot. Gard. 3 : 162. 4: 184. $p l .1,2,19$. 5: 165. — Gard. Chron. iii. 18: 519, 523. $f$. 91-3.

Y. Lenneana Baker, Kew Bull. 1892 : 7.

? Y. aloifolia Regel, l. c. 34 .

Y. Mooreana Hort.

Y. Ghiesbreghtii Hort.

Y. Roezlii Hort.

Yucca - ? Schlechtendal, Linnaea. $17: 270$.

Dracaena Lenneana Hort.

D. Lennei Hort.

D. Ehrenbergii Hort.

D. Fintelmanni Hort.

D. yuccoides Hort.

Usually with several trunks from a swollen base similar to that of $\mathrm{No}$ lina, rough barked in age. At length a large tree 8 or $10 \mathrm{~m}$. high, compactly branched above. Leaves rigidly spreading, clear green, glossy, plane or a little plicate, with soft green tip, .5 to $1 \mathrm{~m}$. long, 50 to $75 \mathrm{~mm}$. wide, scabrid-margined and sometimes a little roughened on the dorsal ridges. Inflorescence panicled close to the leaves, glabrous. Flowers white or creamy : style short, oblong. Fruit oblong-ovoid: seeds nearly circular, 8 to $10 \mathrm{~mm}$. in diameter.-Plates 51. $82, f .1 .84, f .7$.

Central America, where it is universally cultivated, flowering from February to April, and common elsewhere in gardens; but the exact place of its nativity remains to be discovered.

According to Mr. Baker, Y. Mooreana is a garden name for a small-flowered form, and $Y$. Ghiesbreghtii, for one with more rigid and scabrous leaves. From Koch's statement, * this species appears to have been cultivated in

* Belg. Hort. 1862 : 110. 
European gardens under the erroneous name $Y$. Californica.

I do not find herbarium material or published records showing the native home of $Y$. elephantipes, and though it. is cultivated everywhere in the interior as a hedge or dooryard plant, it is not wild in Guatemala between Puerto Barrios and San José, nor in Honduras between Puerto Cortez and Santa Cruz de Yohoa, and a gentleman who has traveled extensively. in Salvador and is familiar with the plant reports it as occurring in that republic only in cultivation. Doubtful reports locate it in the mining region back of Tegucigalpa, Honduras, and near the Atlantic coast about Bluefields, Nicaragua, - the latter being more probable, as it is more likely to belong to the Atlantic slope than the South Coast. In foliage it is much like $\boldsymbol{Y}$. aloifolia Draconis, the flowers of which, however, are different. It is probably this species which occurs, in small specimens, in the gardens of Belize, where the poetic negroes and Caribs call it "May-pole." The Mexican specimens collected by Schiede and Deppe in 1829 at the Hacienda de la Laguna (about five leagues south of Jalapa, according to a note published by Schiede*) were doubtless obtained from a cultivated plant, though Schlechtendal (Linnaea. $17: 270$ ) speaks of its frequent occurrence and mentions the names isote and palmita as applied to this $Y$ ucca.

Throughout Guatemala and Honduras, this tree is known as "Izote†," and while it is chiefly cultivated as a rather poor hedge plant, the flowers are prized as a table vegetable and they are frequently exposed for sale in the markets of Guatemala City and other towns, the usual method of employing them being to fry them with eggs. No use appears to be made of the leaf-fiber, other cordage mate-

* Baker, Journ. Linn. Soc. Bot. 18:222. - Schiede, Linnaea. 4 : 232.

† See Jáuregui, Vicios del lenguaje y provincialismos de Guatemala. 340. (Guatemala, 1893). - It is erroneously called $Y$. gloriosa. 
rials being abundant and apparently more easily manufactured.

M. Pittier informs me that in Costa Rica, everywhere on the central plateau as well as on the Pacific slope a Yucca called "Itavo" or "Itabo" is cultivated as a hedge plant and its flowers sold for the table, and it is doubtless this species, though I have been unable to see material representing it.

22. Leaves from sparingly denticulate becoming sparingly filiferous, thick and firm.

Y. Treculeana Carrière, Rev. Hort. 1858: 580. 1861 : 305. 1863: 13,55 . $1869: 406 . f .82$. - Baker, Gard. Chron. 1870: 828. Journ. Linn. Soc. Bot. 18 : 226. Kew Bull. 1892 : 8. - Lemaire, Ill. Hort. 13 : 97 . Engelmann, Trans. Acad. St. Louis. $3: 41,55,210$, 212. - Rev. Hort. 59 : 368. f. 74. - Garden. 1 : 161. 7 : 11. 8: 131. 12: $328,369 . p l .94$. 35:585.f.Sargent, Silva. $10: 9 . p l$. 498. - Gardening. 4 : 371. f.-Coulter, Contr. U. S. Natl. Herb. $2: 436$. Havard, Bull. Torr. Bot. Club. 23 : 37.

Y. aspera Regel, Ind. Sem. Hort. Petropol. 1858:24. Gartenflora. 8:14, 35. - Engelmann, Trans. Acad. St. Louis. 3 : 37, 210, 212.

Y. longifolia Buckley, Proc. Phila. Acad.1862:8. Gard. Monthly. 17: 69. - Gray, Proc. Phila. Acad. 1862: 167.

Y. Vandervinniana Koch, Belg. Hort. 1862: 131.

Y. argospatha Verlot, Rev. Hort. 1868: 393. - Belg. Hort. 1870 : 23.

$Y$. contorta Hort.

Y. cornuta Hort.

$Y$. agavoides Hort.

Simple or loosely few branched tree usually under $5 \mathrm{~m}$. high. Leaves thick and rigid, very concave, blue-green, shagreen-roughened, pungent, .9 to $1.25 \mathrm{~m}$. long, 25 to $50 \mathrm{~mm}$. wide, brown margined, entire or irregularly denticulate, soon becoming sparingly and finely fliferous. Inflorescence usually short-stalked, glabrous, with large bracts below. Flowers white, occasionally tinged with purple: style slightly contracted, short: stamens quickly hooked. Fruit oblong: seeds $5 \times 6$ to $7 \mathrm{~mm}$. - Plates $52-$ 54. $84, f .8$.

South central Texas, southward to Torreon and Tampico. - Plate 95, f. 2. 
Two fairly distinct morphological and geographically separate forms of this species, which appears to be the " palma loca" (scattered palm) of the Mexicans, are found, and these may be separated as follows: -

Leaves long and slender. Flowers rather small.

Y. Treculeana.

Leaves broader. Flowers larger. var. canaliculata.

Y. Treculeana Carrière.

Synonymy as above.

The long- and slender-leaved small tree of the Texas region, from New Braunfels west to beyond Devil's river and south to about Torreon, Mexico. - Plates 52. 84, f.8.

Y. Treculeana canaliculata (Hooker) Trelease.

Y. canaliculata Hooker, Bot. Mag. iil. 16. pl. 5201. (1860).-Baker, Gard. Chron. 1870: 1217. - Engelmann, Trans. Acad. St. Louis. 8: 43. - Garden. 1: 152. 8: 134. - Watson, Proc. Amer. Acad. $14: 252$.

Y. canaliculata pendula Koch, Belg. Hort. 1862 : 131.

Y. recurvata Hort, in part.

Y. revoluta Hort.

Y. undulata Koch, Belg. Hort. 12 : 132 . (1862).

Y. Treculeana undulata Hort.

The broader-leaved plant of the chapparal of the coast region from about Corpus Christi, Tex., to the vicinity of Tampico, Mex., and, in the foot hills, to about Monterey, Mex. - Plates 53. 54.

The descriptive garden synonyms of both species and variety apparently pertain to young plants. In two trade lists, issued respectively in September 1901, and January 1902, Mr. Carl Sprenger of Naples includes the names $Y$. Treculeana glauca and $Y$. Treculeana undulata, but without indication of the characters of the plants, so that it is possible here merely to call attention to them. The second name probably refers to the form called $Y$. undulata by Koch.

222. Leaves with conspicuous marginal fibers.

3. Leaves thin and flexible, the fibers slender. 
Y. Sснотті Engelmann, Trans. Acad. St. Louis. $3: 46$. (1873). - Watson, Proc. Amer. Acad. 14: 252. Baker, Journ. Linn. Soc. Bot. 18 : 228. — Trelease, Rept. Mo. Bot. Gard. 4:185. pl. 3.- Sargent, Silva. 10:17. pl. 501. - In part.

Y. macrocarpa Engelmann, Bot. Gazette. 6:224. (1881). 7:17. Baker, Kew Bull. 1892 : 8. -Trelease, Rept. Mo. Bot. Gard. 3 : 162. pl. 46 .

? Y. Mazeli Chabaud, Belg. Hort. 1882:222. - Wiener Ill. GartenZeit. 11 : 347 . - Baker, Kew Bull. 1892 : 8.

Arborescent, rarely over 3 or $4 \mathrm{~m}$. high, simple or few branched above. Leaves blue-green, smooth, rather rigidly divergent, thin, concave, pungent, 20 to $40 \mathrm{~mm}$. wide, very finely and often sparingly filiferous. Inflorescence densely panicled close to the leaves, very tomentose or rarely nearly glabrous. Flowers subglobose. Fruit oblong, mostly large: seeds $7 \times 9 \mathrm{~mm}$. - Plates 55. 85, f. 1 .

Southern Arizona, especially about Benson and Nogales, and as far into the Mexican state of Chihuahua at least as Colonia Garcia. Flowering in late summer. - Plate 96, f. 1 .

When, in 1882, Dr. Engelmann described fuller material of the Arizona Yucca which he had named $Y$. macrocarpa the year before, he was so impressed with the resemblance of its tomentose panicle to the fragments of inflorescence in the Torrey herbarium accompanying the leaves of what he had called $Y$. Schottii, that he suggested that the latter might possibly be only a short-leaved form of the same species. This suggestion has been adopted by a number of recent writers, who, irrespective of a prior use of the name macrocarpa in the genus, have come to look upon $Y$. macrocarpa Engelm. as a synonym of $Y$. Schottii.

This $Y$. Schottii of recent writers is abundant to the west and northwest of Nogales, as far, at any rate, as the vicinity of Benson and the Pajarito mountains, and there becomes a small tree two or three meters high, most frequently unbranched; and it is especially marked among the Yuccas of the region by the bluish-green color and thinness of its smooth concave finely filiferous brown-margined leaves, and 
the usual dense tomentose pubescence of its panicle which is closely branched in the crown of leaves, though on occasional unmistakable specimens of this species nearly or quite glabrous panicles are seen.

Though mentioned as a Mexican plant by Mr. Hemsley,* he gives only the original locality of Schott, near the boundary, and Professor Sargent, $\dagger$ who states that it ranges southward through Sonora, gives no details of its distribution in Mexico. Specimens and photographs of the only Yucca observed in the Cape region of Lower California by Mr. Brandegee, which he has kindly allowed me to see, do not show that this is distinguishable from $Y$. Schottii of Arizona.

Leaves of $Y$. Mazeli, collected in the Thuret garden at Antibes by Mr. Alwin Berger, are scarcely to be compared with any species known to me except $Y$. Schottii, though they differ from those of the latter that I have seen in being persistently a little denticulate.

\section{Y. Schottii Jaliscensis Trelease.}

Y. Treculeana ? Rose, Contr. U. S. Natl. Herb. 5 : 241.

Y. Schottii Urbina, Cat. Pl. Mex. 353.

A stout large branched tree, with leaves sometimes very large. Scarcely otherwise distinguishable from the type, and, like it, blooming in late summer or autumn. - Plate 56.

Chiquilistlan to Zapotlan, Jalisco, Mex., frequent in hedges but of undetermined spontaneous range.-Plate $96, f .1$.

In speaking of Mexican fiber plants, Dr. Roseł mentions one known as " isote," which he doubtfully refers to $Y$. Treculeana and states is common on the table lands of western Mexico. A leaf of isote bought by him in the market of Guadalajara (E. B. 68), which he was kind enough to let me examine, though measuring $75 \times 750$

\footnotetext{
* Biol. Centr.-Amer. 3 : 371.

+ Silva, 10: 17 .

$\ddagger$ Contr. U. S. Natl. Herb. 5 : 241
} 
mm. and therefore much larger than usual in $Y$. Schottii, is not otherwise different from the leaves of that species. In 1892 Mr. Marcus E. Jones collected and photographed a Yucca at Chiquilistlan, to which he gives the local name " desoti, " - which is doubtless merely a phonetic variant of isote or izote; and good specimens, evidently of the same species, were made by Mr. Pringle at Zapotlan (no. 4392) and distributed under the name $Y$. Schottii.

While the herbarium specimens of this izote of the Mexican state of Jalisco are hardly referable elsewhere than to $Y$. Schottii, Mexicans in the vicinity of the Pajarito mountains, west of Nogales, assured me that the true $Y$. Schottii of that region is not the izote that they knew further south, which, as they asserted, is a larger, more branched tree. Photographs taken by Mr. Jones, in fact, show this to be true, at Chiquilistlan, as does the accompanying plate from photographs taken by me in 1901 at Zapotlan, where, though very abundant in the suburbs, in hedge-rows, etc., the izote appears to occur only as a cultivated plant. The much larger size, stout trunk enlarged below, more branched habit, and rather more staring leaves, are the only characters by which I am able to distinguish it from $Y$. Schottii, so that at most I should call it a variety of the latter. The tree figured by Dr. Rose* from a photograph taken in the vicinity of the city of Mexico, and supposed to represent the izote, is doubtless $Y$. australis.

33. Leaves thick and firm, with usually coarser flbers.

4. Leaves narrow, falcate, smooth.

Y. Brevifolia Schott, in Torrey, Bot. Bound. 221. (1859).- Engelmann, Trans. Acad. St. Louis. 3 : 46.

Y. puberula Torrey, Bot. Bound. 221.

Shortly caulescent, scarcely reaching a height of $2 \mathrm{~m}$., mostly cespitose. Leaves green, smooth, rigidly divergent, often falcate, thick, planoconvex, very pungent, .3 to $.6 \mathrm{~m}$. long, 6 to $25 \mathrm{~mm}$. wide, the margin freely

*1. c. $p l .38$. 
filiferous. Inflorescence panicled close above the leaves, glabrous. Flowers apparently rather small, with tapering style. Fruit baccate, large: seeds 9 to $10 \times 10$ to $12 \mathrm{~mm}$. - Plates 57-59.

About Nogales, Arizona, on the Santa Cruz river, and in the rugged mountains west of that city. Flowering in May.-Plate 96, f. 2.

In the course of his work connected with the original survey of the boundary between the United States and Mexico, Mr. Arthur Schott collected, in the upper Santa Cruz valley, and near the boundary monument in the Sierra del Pajarito, a small arborescent $Y u c c a$, for which he proposed the manuscript name $Y$. brevifolia. His specimens were referred to $Y$. puberula Haw., in 1859 , by Dr. Torrey, who, however, printed Schott's proposed name as a synonym. In 1873 Engelmann, recognizing that they do not represent the $Y$. puberula of Haworth, which is an acaulescent plantscarcely differing from typical $Y$. flaccida, proposed for them the name $Y$. Schottii, with the remark that Mr. Schott " may possibly have mixed the fruit of $Y$. baccata with the foliage of the new plant; but the leaves appear so peculiar that there can scarcely be a doubt about the distinctness of the species to which they belong."

The fragmentary specimens collected by Schott, by which and his notes and sketches alone his $Y$. brevifolia appears to berepresented in herbaria, consist of a sheet in the Torrey herbarium, bearing smooth, stoutly pointed, very thick and rigid leaves cut off above the base, about $25 \mathrm{~mm}$. wide, plano-convex except toward the pungent apex where they are somewhat concave, and with long slender straight marginal fibers; panicle fragments, some of which are glabrous and others softly tomentose; flowers, the bases of which are pubescent, suggesting that they probably belong with the pubescent pedicels; and a glabrous branchlet bearing an immature fruit which may have been either erect on an ascending branch, or, as is more likely, pendent from a 
drooping one: and a sheet in the Engelmann herbarium with a similar leaf, two glabrous panicle fragments, and several detached flowers which appear to have come from them. Schott's notes and sketches in the Engelmann herbarium show that the trunks were 1.75 to $2.5 \mathrm{~m}$. high, the leaves about $.3 \mathrm{~m}$. long, and the panicle lax with pendent fleshy fruit.

It has long been evident that if, as Dr. Engelmann thought doubtful, these fragments belong together, they represent a species very different from any Yucca which has been found by later collectors, and that the leaves can scarcely be compared closely with those of any recognized species, so that in August 1900, and April 1902, I took occasion to revisit the original localities, respectively a few miles to the eastward and a few miles to the westward of Nogales, where, as I had hoped, the species was found in abundance, though, as is usually true in such cases, varying to a surprising extent from the original fragmentary material.

$Y$. brevifolia, as it occurs rather sparingly in the cañons of the Pajarito and adjacent ranges, to the west of Nogales, and abundantly among the low hills between that eity and the Santa Cruz river, to the east, is most commonly cespitose and often acaulescent, though it not infrequently forms a trunk 1 to $1.5 \mathrm{~m}$. high, and the thick apple green abundantly filiferous leaves, which are frequently falcately curved to one side, are usually about $.75 \mathrm{~m}$. in length, but vary in this respect, and especially in width, which, commonly about $20 \mathrm{~mm}$., may reach $30 \mathrm{~mm}$., or be reduced to 5 or 6 $\mathrm{mm}$. Unfortunately none of the plants flowered in 1900 and my second visit was too early in the season, so that neither flowers nor good fruit could be obtained, but a few panicle remnants from previous years, branched rather loosely shortly above the leaves, - though not so laxly as is shown in the sketches by Mr. Schott, - glabrous, and showing where the fruits had disarticulated, leave little doubt that 
the inflorescence is typically glabrous; and fruit-bases and seeds show that the fruit is baccate.

If, as now seems more probable than ever, the Torrey sheet of $Y$. brevifolia contains parts of two species, Schott's name may best apply to what Dr. Engelmann considered the most characteristic part, the leaves, particularly as the name Schottii has now become current for the remainder. The later $Y$. brevifolia, Engelmann (1871), as has been stated above, is now proposed as the type of the genus Clistoyucca under its first published (varietal) name arborescens.

44. Leaves relatively broader, usually smooth.

\section{Y. aUstralis (Engelmann) Trelease, Rept. Mo. Bot. Gard. 3: 162. $p l .3,4$. (1892).}

Y. baccata australis Engelmann, Trans. Acad. St. Louis. 3 : 44, 46. (1873), - in part. - Watson, Proc. Amer. Acad. 14: 252. - Baker, Journ. Linn. Soc. Bot. 18 : 229.

Y. filifera Chabaud, Rev. Hort. 48:432. f. 97. (1876).-Carrière, Rev. Hort. 56 : 53. f. 12, 13. - Garden. 10 : 554. f. - Gard. \& Forest. 1: 78. f. 13, 14. - Baker, Kew Bull. 1892:8. - Gard. Chron. iii. 3 : 743, 751. f. 97, 100. - Amer. Florist. 8 : 59. f.-Urbina, Cat. Pl. Mex. 353.

Y. canaliculata filifera Fenzi, Bull. R. Soc. Tosc. di Orticult. 14: 278. pl. 9. (1889).

? Y. periculosa Baker, Gard. Chron. 1870 : 1088.

? Y. baccata periculosa Baker, Jonrn. Linn. Soc. Bot. 18 : 229.

? $\boldsymbol{Y}$. polyphylla Baker, Gard. Chron. 1. c.

? $Y$. circinata Baker, Gard. Chron. 1. c.

? Y. baccata circinata Baker, Journ. Linn. Soc. Bot. 18 : 230.

? Y. scabrifolia Baker, Gard. Chron. 1. c.

? Y. baccata scabrifolia Baker, Journ. Linn. Soc. Bot. 18: 230.

? Y. fragilifolia Baker, Gard. Chron. 1. c.

? Y. baccata fragilifolia Baker, Journ. Linn. Soc. Bot. 18 : 230.

? Y. baccata Hystrix Baker, Journ. Linn. Soc. Bot. 18 : 230. (1880).

Y. Treculeana Rose, Contr. U. S. Nati. Herb. 5. pl. 38.

Dasylirion aloefolium Carrière, Rev. Hort. 1884 : 53.

A large thick- and rough-stemmed tree, at length much branched. Leaves rigiuly spreading, pungentiy stout pointed, green, usually about $.3 \mathrm{~m}$. long and $25 \mathrm{~mm}$. wide but occasionally of double these dimensions, thick, plano- or concavo-convex, smooth or exceptionally a little scabrid on the dorsal angles, somewhat sparingly rather coarsely filiferous. Inflorescence on an exserted peduncle, obiong, pendent, with pendent 
branches, glabrous. Flowers creamy white, rather small; style short, constricted; stigma deeply 6 -lobed. Fruit oblong: seeds $7 \times 7$ to 8 mm. - Plates 60.61. 85, f. 2 .

Tablelands of Mexico, from southern Coahuila, central Nuevo Leon and western Tamaulipas to Queretaro and, perhaps, the Federal District, where, at least, it occurs as an introduced plant. - Plate $96, f$. 2 .

Fragmentary specimens of the large tree Yuccas of northern Mexico, which are locally called palmas, in contrast with the smaller narrow-leaved species, like $Y$. rostrata and $Y$. radiosa, which are known by the diminutive names palmita or palmilla, were collected about Saltillo by Dr. Gregg, as early as 1846, and near Parras by Dr. Thurber, in 1853. In his personal narrative, ${ }^{*}$ John Russell Bartlett, United States Commissioner on the United States and Mexican boundary survey of 1850-1853, speaks of these large trees and gives a figure representing a branched tree, evidently 8 or $10 \mathrm{~m}$. high, with a number of erect stalked panicles. This is the form which Dr. Torrey $\dagger$ refers to under $Y$. baccata, though he considers the single leaf and immature fruit collected by Thurber as insufficient to warrant either the description of a new species or its positive identification with his $Y$. baccata macrocarpa.

About 1860, Roezl and Galeotti sent seeds of many decorative Mexican plants to European dealers, by whom they were distributed, and among these were seeds of one or more of the large Yuccas, which were soon cultivated in a number of gardens in the southern countries, in part under the dealers' name $Y$. filifera. Ten years later, Mr. Baker provisionally published the names $Y$. periculosa, $Y$. polyphylla, $Y$. circinata, $Y$. scabrifolia and $Y$. fragitifolia, for plants cultivated in England by Mr. Wilson Saunders, but concerning the origin of which nothing is said, and

* Personal Narrative of Explorations and Incidents. 2 : 490-1. (1854).

$\dagger$ Bot. Bound. 222. (1859). 
in connection with these provisional species he mentions the Thurber material as representing still another, but without giving it a name.

Both the Gregg and Thurber specimens in 1873 were unmistakably referred to his $Y$. baccata australis by Dr. Engelmann, who suggests as possible synonyms the group of provisional species of Baker and the undescribed $Y$. filifera of gardens.

In 1876, one of the plants raised from Roezl's Mexican seed flowered near Hyères, France, and was figured under its garden name, $Y$. filifera, by Chabaud, who adds $Y$. albospica* (which appears in large part to be $Y$. constricta) and $Y$. canaliculata (which is properly a form of $Y$. Treculeana) as synonyms. Accompanying notes by Carrière, $\uparrow$ who suggests its possible generic separability from $Y$ ucca, show that it then occurred further in gardens as $Y$. Parmentieri $\ddagger$ and $Y$. Japonica.

It has also been grown as Dasylirion aloefolium, $\S$ and the complication of its nomenclature is increased by the addition of the genus Roezlia of Roezl (not of Regel) as synonymous with $Y$. filifera, $\|$ and this name and Litia (sometimes also spelled Lilium) have been somewhat current in gardens and horticultural papers for $\boldsymbol{Y}$. Parmentieri, under which name, as stated above, $Y$. filifera has been cultivated, though Lilia regia, Lilium regium, Roezlia regia, and $R$. bulbifera of gardens are properly synonymous with the real $Y$. Parmentieri, which is also known as $Y$. argyrophylla, $Y$. Toneliana, and $Y$. Pringlei, and

* See Engelmann, Trans. Acad. St. Louis. sి : 37, 210. - Belg. Hort. 1880 : 31 .

$\dagger$ Rev. Hort. $48: 423,432$.

† Engelmann, $l$. c. $3: 37$.

§ Carrière, Rev. Hort. 1884 : 53.

\|l Chabaud, l. c.

I See Gartenflora. 10 : 264, 298.- Belg. Horticole. 13 : 327.33 : 133. Gard. Chron. n. s. 11 : 656 . - Rev. Hort. 59 : 353. - Curtis's Bot. Mag. iii. 47. pl. 7170 . 
is really Furcraea Bedinghausii, a species which also possesses a number of other generic as well as specific synonyms.

In his synopsis of Aloineae and Yuccoideae, Mr. Baker,* recognizes the Yucca baccata australis of Engelmann, with $Y$. filifera as a synonym, treating his own periculosa, circinata, scabrifolia and fragilifolia as separate varieties of $Y$. baccata, and adding to this species another garden variety, under the name Hystrix, while he places his $Y$. polyphylla as a synonym under what is here called $Y$. radiosa.

Since the publication of the papers referred to, knowledge of this tree has increased greatly, and there can no longer be any doubt as to its specific separability from both $Y$. baccata and $Y$. marcocarpa (Torrey), and although it is unfortunate that an established name is displaced thereby, there is no reason why the tree should not be designated by the name australis which Dr. Engelmann first applied to it varietally, unless one of Mr. Baker's provisional names, - all of which refer to plants still unknown in a wild state and comparable with immature forms of other species, - should ultimately prove, contrary to his own opinion, to refer to the same plant, in which case it antedates this name of Engelmann.

Yucca australis, as here understood, forms large forests in the valleys about Monterey, and is especially abundant immediately to the north of that city between Chipinque and Topo Grande, and though there are many breaks, these forests continue in open places along the Mexican National railroad to the vicinity of San Luis Potosi, and even as far south as the vicinity of the city of Mexico some trees occur. On the Mexican Central railroad it is seen, accompanied by $Y$. Treculeana and $Y$. rigida in varying quantity, about La Mancha and thence south to about Symon. For the sake of verification, Parras was visited, and it may be said that Thurber's material certainly represents the tree that is com-

* Journ. Linn. Soc. Bot. 18:229. (1880). 
mon about Monterey, sinceno other comparable plant occurs about Parras, and the same species is common about Saltillo, where Gregg's leaves were collected, though a very different plant, some leaves of which, however, might be mistaken for some of those of this species, accompanies it in the mountains south of that city. It is also seen from about San Luis Potosi to the edge of the table-land, and from Monterey it reaches southeastwards as far as the central part of the state of Tamaulipas.

Throughout the large area covered by these observations, - and which is doubtless capable of extension, $-Y$. australis is distinguished from all of its congeners by the possession of a long rather narrow panicle hanging straight down from the cluster of leaves, on a quickly arched base, even before anthesis; and as this character is as marked in the fruiting clusters and even in the old inflorescence remains of former years as in the flower clusters, the recognition of the species is very easy throughout most of the territory in which it grows. ${ }^{*}$ Typically it becomes a large much and loosely branched rough-barked tree, but in cultivation it often attains gigantic proportions before branching, with an extent of many feet of the trunk covered by still green leaves, as in the streets of C. P. Diaz; and in the high dry region along the Tropic of Cancer, as about Moctezuma, a low short-branched form occurs, sometimes not over 3 or $4 \mathrm{~m}$. high, but with a trunk a meter or more in diameter. Though usually designated simply as palma, it seems to be sometimes called palma de San Pedro, and sometimes palma samandoca.

Y. valida Brandegee, Proc. Calif. Acad. ii. 2 : 208. pl. 11. (1889). - Trelease, Rept. Mo. Bot. Gard. 3 : 162.

Similar in dimensions, habit, foliage, floral details and fruit, to the preceding. Inflorescence broadly ovoid, close to the leaves, continuous in

* The erect panicle shown in Bot. Mag. iii. 47.pl. 7197, was produced on a $\log$ from about Monterey, and therefore doubtless of this species, but is quite unlike anything $I$ have seen in nature, among thousands of trees examined. 
direction with the branch, hence either erect, horizontal, ascending or downwardly turned. - Plates 62-67. $85, f .3$.

Central Lower California, and on the high table land of central Mexico in the states of Durango, Zacatecas and San Luis Potosi. - Plate 97, f.1.

Reference has been made to a figure by Bartlett, ${ }^{*}$ representing somewhat sketchily a large branched tree with erect panicles, supposed to illustrate the largest $Y$ ucca of the region between Parras and Saltillo, and of which specimens were collected by Dr. Thurber on the boundary survey. This figure has been commonly discredited since the pendent inflorescence of $Y$. australis has been known, though a trunk of the latter, sent to Kew from about Monterey by Mr. Pringle in 1888, bore in 1890 a panicle not unlike those shown by Bartlett, $\dagger$ and Dr. Barroeta of San Luis Potosi once sent to Dr. Engelmann a sketch showing a merely arched inflorescence.

Among the plants studied by him in Lower California, Mr. Brandegee found a tree Yucca which he named $Y$. valida, publishing a very inadequate description and a reproduction of a Kodak photograph showing a tree with short thick trunk quickly breaking into a number of erect secondary stems apparently some 8 or $10 \mathrm{~m}$. high.

About Durango, Mexico, in April, 1900, I observed Yuccas of the simpler trunk form assumed by $Y$. australis, and with similar foliage and flowers, which attracted my attention by their relatively short and thick spreading panicles, markedly different from the elongated and pendent flower-clusters of the latter species. So far as inflorescence could be seen, this proved to be the only species of this type along the Mexican Central railroad between about Cañitas and Chicalote, and it forms great forests on the elevated red lands about Gutierrez, Fresnillo and Calera. where it often assumes the low compact form noted for

* Personal Narrative. 2 : 490-1. (1854).

+ Baker, Bot. Mag. iii. 47. pl. 7197 . 
$Y$. australis to the eastward in the same latitude and altitude, some of the short main trunks measuring fully 2 meters in diameter.

So far as I can see, this species, which differs from $Y$. australis chiefly in having its panicles continuous in direction with the branches that bear them, and hence either erect, oblique or horizontal, is the same as that described from Lower California under the name $Y$. valida by $\mathrm{Mr}$. Brandegee, who has kindly allowed. me to see his type material of that species; and if so its range crosses both the Sierra Madre mountains and the Gulf of California, though I do not know that it has been collected in the intervening state of Sinaloa. Because of the curly threads on its leaf margin, it is known as the palma china, or curly $Y u c c a$, and toward San Luis Potosi it is associated with the palma samandoca ( $Y$. australis), which appears to be entirely absent from the highlands of Zacatecas, though it replaces $Y$. valida to the east of the city of San Luis Potosi.

444. Leaves large, very coarsely fliferous, the back very scabrous except in the last.

Y. BaCcata Torrey, Bot. Bound. 221. (1859). - Baker, Gard. Chron. 1870 : 923. Journ. Linn. Soc. Bot. 18 : 229. —Engelmann, Bot. King. 496. Trans. Acad. St. Louis. 3 : 44. - André, Rev. Hort. 59 : 368. $f$. 73, 75. - Watson, Proc. Amer. Acad. 14 : 252. Coulter, Contr. U. S. Natl. Herb. 2 : 436. - Havard, Proc. U. S. Natl. Mus. 1885 : 516. Bull. Torrey Bot. Cl. 22 : 119. 23 : 37. - Coville, Contr. U. S. Natl. Herb. 4 : 202. - Merriam, N. A. Fauna. 7 : 352. pl. 12. - Gard. Chron. iii. 28 : 103. f. 27. - Garden, 16 : 516. $f . \quad 35: 585 . f . \quad 55: 81 . f .-$ Britton \& Brown, Ill. Fl. 1 : 426. f. 1025. - ? Rept. U. S. Dept. Agr. 1870: 418. pl. 25. - Belg. Hort. 30 : 266. - Ill. Hort. 20 : 23. pl. 115.

Low, usually from a stont prostrate short-branched caudex. Leaves rigidly spreading, bluish green, about .6 m. long and $50 \mathrm{~mm}$. wide, con- 
cave, shagreen-roughened, narrowly brown-bordered, coarsely flliferous. Flowers very large for the genus, oblong-campanulate, the lanceolate segments about $75 \mathrm{~mm}$. long: style slender, elongated, gradually tapering; stigmatic lobes short. Fruit very large (as much as $200 \mathrm{~mm}$. long), mostly conical-ovold, with adnate calyx-disk and flament bases: seeds $7 \times 9$ to $10 \mathrm{~mm}$. - Plates $6 s-69.85, f .4$.

Trinidad, Colorado, to Silver City, N. Mex., and west to southern Nevada. - Plate 97, f. 2.

This, the first discovered of the western fleshy-fruited Yuceas, differs from the species which have been confounded with it in its prostrate caudex, the crowns of which rarely rise much above the earth, its very large pendent flowers, and its decidedly conical large fruit with the base of the perianth adnate as a conspicuous disk, and the bases of the filaments forming fleshy papillae, as in $Y$. aloifolia. A note by Dr. Palmer* on the uses made of $Y$. baccata by the Indians, and many of the published references under this name, may refer to the next species, while the Yucca baccata of the Pacific coast is what is here called $Y$. Mohavensis.

Y. macrocarpa (Torrey) Coville, Contr. U. S. Natl. Herb. 4 : 202. (1893). - Havard, Bull. Torrey Bot. Club. $23: 37$.

Y. baccata macrocarpa Torrey, Bot. Bound. 221. (1859).

Y. baccata australis Havard, Proc. U. S. Natl. Mus. 8 : 470, 516.

Arborescent, subsimple, becoming 3 to $5 \mathrm{~m}$. high. Leaves yellowishgreen, . .5 to I $\mathrm{m}$. long, 40 to $50 \mathrm{~mm}$. wide, usually rough, concave, coarsely fliferous. Panicle glabrous or occasionally pubescent, the bracts at first often brownish. Flowers mostly more globose and smaller (the perianth segments usually about $40 \mathrm{~mm}$. long). Fruit oblong, not usually as large as in $Y$. baccata: seeds 5 to $6 \times 6$ to $8 \mathrm{~mm}$. Plates 70.71 .85 , f. $5.86, f .2$.

Las Cruces, N. M., to the Dragoon pass, Ariz., northern Chihuahua, and the vicinity of Presidio. - Plate 98, $f .1$.

On the plains of western Texas, near the Limpio, and in

* Amer. Journ. Pharmacy. 50 : 586. (1878). 
the vicinity of Presidio del Norte, Dr. Bigelow is said to have found a $Y$ ucca 3 to $5 \mathrm{~m}$. high, with leaves almost exactly like those of $Y$. baccata, and longer though not thicker fruit, for which Dr. Torrey proposed the name of $Y$. baccata macrocarpa. In 1871, Dr. Engelmann* merged this form with $Y$. baccata, noting that though northward a low plant, this species becomes a tree farther south; but in his notes on the genus, published two years later, $\dagger$ he accords names to two forms of $Y$. baccata, the typical subacaulescent, large-flowered and long-styled plant, which he calls forma genuina, and the southern branched arborescent plant with smaller flowers and shorter style, which he calls variety australis, noting that certain California specimens are intermediate in foliage between the northern and southern extremes.

In discussing the plants collected or studied by the Death Valley expedition, Mr. Coville applied the name $Y$. macrocarpa to the baccate tree Yucca of southern California and southern Nevada, with the qualification that though he had not had an opportunity to investigate the identity of this Mohave Desert species with the West Texas form to which Dr. Torrey had applied the name varietally under $Y$. baccata, they were supposed to be the same; and Dr. Merriam accepted this conclusion in his account of the distribution of the tree in the Death Valley region.

On the occasion of the flowering of a Yucca trunk received by the New York Museum of Natural History from Sierra Blanca, Texas, Professor Sargent, $\ddagger$ in publishing a figure of it, expressed the opinion that the specific name macrocarpa should be limited to this tree of western Texas; and the next year $\S$ he proposed for the California plant

- Bot. King. 496.

† Trans. Acad. Sci. St. Louis. 3 : 44.

$\ddagger$ Gard. \& Forest. 8 : 301. f. 42 . (1895).

§ Gard. \& Forest. 9 : 104. 
the name $Y$. Mohavensis, and followed the conclusions then reached in his subsequent treatment in the Silva * of the two forms, the Yucca macrocarpa in both instances being the tree which occurs about Sierra Blanca with the true $Y$. macrocarpa but possesses a gamophyllous perianth and is here treated as one of the types of the genus Samuela.

Though leaves resembling those of $Y$. baccata have occasionally been brought in from the general vicinity of $\mathrm{El}$ Paso, Texas, and the adjacent parts of New Mexico, out of the range of $Y$. baccata, together with some photographs showing a tree-like growth, and flowers of smaller size than those of $Y$. baccata, the absence of herbarium material representing the original collections of $Y$. baccata macrocarpa indicated the desirability of making collections of all of the arborescent Yuccas of the great bend of the Rio Grande, and for this purpose, in August, 1900, I drove from Marfa, on the Southern Pacific railroad, to Presidio, on the river, finding at intervals the plant of $\mathrm{El} \mathrm{Paso}$ and New Mexico, and, in sandy places, $Y$. radiosa (which seems not to have been noted by the boundary botanists), but, rather unexpectedly, no trace of the Sierra Blanca tree figured by Professor Sargent as $Y$. macrocarpa. The latter, then, may be eliminated as certainly not the plant to which the name macrocarpa was applied by Dr. Torrey, though the latter also occurs at Sierra Blanca.

Yucca macrocarpa, as it occurs in the vicinity of Presidio and thence in general west to south-central Arizona and north to Las Cruces, when seen from a distance resembles considerably $Y$. Treculeana, though usually of a yellowergreen foliage than that species. The trunk very rarely branches, and is usually 2 or $3 \mathrm{~m}$. high, though occasional specimens are seen exceeding 5 meters. Its concave stiff leaves are usually .6 or .9 m. long and about $40 \mathrm{~mm}$. wide, though sometimes reaching a length of over a meter, and,

* Silva. 10: 13. pl. 499. 15. pl. 500 . 
as in $Y$. baccata, they are rough like shagreen on the back and frequently on the upper surface as well, and very coarsely gray filiferous. The flowers and fruit are as described by Dr. Torrey, though the latter varies greatly in form and size. Specimens in the Engelmann Herbarium, collected by Dr. Wislizenus between El Paso and Chihuahua, show that to this extent the $\boldsymbol{Y}$. baccata australis of Engelmann included this species, though in large part it referred to other things, principally what is called $Y$. australis above.

Y. Mohavensis Sargent, Gard. and For. 9 : 104. (1896). Silva. $10: 15 . p l .500$.

Y. macrocarpa Coville, Contr. U. S. Natl. Herb. 4 : 202. (1893). In large part. - Merriam, N. Amer. Fauna 7 :358. pl. 14.

Y. baccata Watson, Bot. Calif. 2 : 164. - Trelease, Rept. Mo. Bot. Gard. 3 : 162. $p l .2,48$. 4 : 185. pl. 20. - Amer. Florist. 8 : 57. f. Orcutt, West Amer. Scientist. 6 : 134.

Y. schidigera Roezl, Belg. Hort. 1880 : 51.

Habit and general characters of the preceding. Style very short, contracted. Fruit mostly smaller. - Plates $68.81, f .6$.

Western Arizona and Southern Nevada to the vicinity of San Diego, California, and Alamo, Lower California, and as far north as Monterey, where Parry first collected it. Plate 94, f. 1.

Though the principal observed difference between this and the preceding lies in the style, which is contracted and short in the one, and elongated in the other, the great area of desert country lying between their known respective localities makes it desirable to recognize them as distinct species. From the locality there can be no doubt that what Roezl collected near San Diego in 1869 and sold to De Smet under the name of $Y$. schidigera was $Y$. Mahavensis, which Dr. Engelmann regarded as intermediate between $Y$. baccata and its variety australis as understood by him.

In addition to the names applied in this paper as synonyms or otherwise to various species of $Y u c c a$ or other 
yuecoid genera, the following, mostly spurious, Yuccas are to be aceounted for:-

Y. acaulis HBK. Nov. Gen. Sp. 1 : 289. (1815).

Said by Engelmann (Trans. Acad. St. Louis. $3: 55$ ) to be a Fourcroya, and by Baker (Journ. Linn. Soc. Bot. 18:231) to consist of leaves of an Agave or Fourcroya and fiowers of a Yucea. It is said by the describer to be called locally "maguay de Cocuy," and to occur abundantly near Caracas and Cumana. The ovary is said to be superior, but the filaments are described as dilated at base and the flowers are particularly compared with those of Agave Cubensis (now called Furcraea Cubensis) which Humboldt elsewhere (Pol. Essay on the Kingdom of New Spain. 2:472. - ed. 3. transl. by Black) states is called "maguey de Cocuy" in the provinces of Caracas and Cumana, so that it is doubtless $F$. geminispina Jacobi, which has the marginal prickles bifid, as those of $Y$. acaulis are said to be. Y. acrotricha Schiede, Linnaea. 4 : 230. (1829).

Briefly described from foliage specimens only, and subsequently and correctly named Dasylirion acrotricha by Zuccarini (PI. Nov, v. min. cogn. $4: 223,228 . p l .1)$.

Y. aletriformis Haworth, Phil. Mag. 1831 : 415. - South Africa.

Obviously, from the locality, if correctly given, not a Yucca, but as yet, so far as I know, unplaced.

Y. angustifolia Karwinsky in Sweet, Hort. Brit. 707. (1839). [ed. 3].

Is $Y$. stenophylla Steudel, mentioned below.

X. Barrancasecea Pasquale, Cat. R. Orto Bot. di Napoli. 108. (1867).

From the statement that the leaves are fibrillate at end, it may be inferred that this plant, cultivated in the Naples garden, is a Dasylirion, but its leaves, which are described as 1 meter long and 3 to $4 \mathrm{~cm}$. wide, and by implication entire, are large and differ in their fibrillate end from those of the described species of that genus with entire leaves.

Y. Boscii Desfontaines, Tableau de l'Ecole de Bot. du Jard. du Roi. 28, 274. (1815). [ed. 2].

This catalogue name, without description and doubtfully placed under the genus Yucea by its author, is now by general consent referred as a synonym to Agave geminiflora Gawler. Nuttall (Trans. Amer. Phil. Soc. 5 : 156), refers to it as from Upper Carolina.

\section{1. graminifolia Zuccarini, Cat. Hort. Monac. 1837.}

Referred to the genus Dasylirion under the same specific name by Zuccarini (Allgem. Gartenzeit. 1838. - Plant. nov. vel min. cogn. 4: 225. pl. 1. - Neumann, Rev. Hort. ii. 4: 250). I am indebted to Professor Radlkofer for bits of the type from Zuccarini's herbarium, at Munich.

Y. horrida Steudel, Nomenclator. 2 : 795. (1841). [ed. 2].

Mentioned by name only, ascribed to Humboldt, and stated to be a synonym of $Y$. spinos $a$, which is referred to below. 
$Y$. longifolia Karwinsky in Schultes, Syst. Veg. 172: 1715. (1830).

This was referred to the genus Dasylirion, under the same specific name, by Zuccarini (Allgem. Gartenzeit. 1838. - Pl. nov. v. min. cogn. 4 : 224. $p l$. 1. - Regel, Gartenflora. $8: 37$ ), and afterward and apparentiy correctly to Beaucarnea, under the same name, by Baker (Lond. Journ. Bot. 1872: 324). Hemsley (Biol. Cent.-Amer. 3: 372) uses the same specific name under the equivalent genus Nolina. Professor Radlkofer has kindly sent me specimens from the plants still cultivated at Munich, from Karwinsky's seeds.

Y. pitcairnifolia Karwinsky in Sweet, Hort. Brit. 707. (1839). [ed. 3.]

Published without description but ascribed to Mexico, and from the specific name perhaps the plant collected by Karwinsky to which Zuccarini (Allgem. Gartenzeit. 6:258) gave this specific name under the genus Dasylirion, from which in 1840 he transferred it to Hechtia under the specific name glomerata, (Plant. nov. v. min. cogn. 4:240. pl. 6).

Y. mubescens Pasquale, Cat. R. Ort. Bot. di Napoll. 108. (1867).

A catalogue name only, not capable of being placed.

Y. serratifolia Karwinsky in Schultes, Syst. Veg. $17^{2}: 1716$. (1830).

This was correctly referred to Dasylirion, under the same speciflc name, by Zuccarini (Aligem. Gartzenzeit. 1838. - Plant. nov. v. min. cogn. $4: 225$ ). I am indebted to Dr. Radlkofer for specimens from plants still cultivated in Munich, from Karwinsky's seeds.

Y. spinosa HBK. Nov. Gen. Sp. 1 : 289. (1815).

The original specimen of this, from Actopan, Mexico, in the Berlin herbarium, is said by Engelmann (Trans. Acad. St. Louis. 3 : 24, 55) to be composed of the flowers of $Y u c c a$, similar to those of $Y$. Treculeand (which occurs in that region) and the leaves of Dasylirion acrotrichum. It would be very far-fetched to apply this name, based on foreign leaves, to $Y$. Treculeana, over which it has long priority.

Y. stenophylla Steudel, Nomenclator. 2 : 795. (1841). [ed. 2 ].

This name, without description, which is substituted for Karwinsky's name $Y$. angustifolia, pertains to a Mexican plant, which might equally well belong to Yucca, Beaucarnea, or Dasylirion, and concerning which I have been able to get no information.

The following artificial hybrids which Mr. Sprenger proposes fully characterizing shortly, but which can not be placed even in the analytical key given above, are included by him in two trade lists, issued respectively in September, 1901, and January, 1902 :-

Y. $\times$ albella Sprenger, Lists 1, 2.

$Y$. $\times$ elegantissima Sprenger, Lists 1, 2. ( $Y$. filamentosa major 우 $\times$ Y. gloriosa). 
Y. $\times$ Elmensis Sprenger, Lists 1, 2. ( $Y$. flamentosa major $+\times Y$. gloriosa).

I. $\times$ Guiglielmi sprenger, Lists 1, 2. ( $Y$. filamentosa 우 $\times Y$. gloriosa).

Y. $\times$ Imperator Sprenger, Lists 1, 2. (Y. filamentosa major + 으. gloriosa glauca pendula).

Y. X liliacea Sprenger, Lists 1,2. ( $Y$. filamentosa ${ }^{\circ} \times$ " . rupestris" [ rupicola]).

Y. $\times$ magnifica, Sprenger, Lists 1,2. (Y. flaccida ㅇ $\times$ Y. gloriosa).

$Y$. $\times$ margaritacea Sprenger, Lists 1, 2. ( $Y$. filamentosa and $Y$. gloriosa).

I. $\times$ praecox Sprenger, Lists 1,2. (Y. filamentosa and Y.gloriosa).

1. $X$ Treleasii Sprenger, Lists 1, 2.

Y. Х viridiflora Sprenger, Lists 1, 2.

Y. $\times$ Vomerensis Sprenger, Lists 1,2. (Y. aloifolia $+\times Y$.gloriosa).

\section{SAMUELA Trelease.}

Perianth openly campanulate, salver-or funnel-form, of thin broadly lanceolate segments the narrowed bases of which are connate into a distinct conical or cylindrical tube. Filaments thick, inserted in the throat, outcurved above; anthers sagittate, horizontal. Ovary narrowly oblong, longer than the oblong 3-grooved style; stigma unequally 6-lobed, openly perforate. Fruit 6-celled, pendent, baccate about a papery core. Seeds thick, marginless, with ruminated albumen. - Low but rather thick trees with large rigid pungent coarsely fliferous leaves and ample large-bracted panicle the branches of which long end in broad bractcovered buds.

Two trees to which, as it chances, no published specific names are applicable, though of the general habit, floral plan and fruit and seed characters of the baccate Yuccas, are distinguished from all known Yuccas in having the perianth distinctly tubular and gamophyllous below, with the stamens becoming free only at its throat; and these characters, marking a very great deviation from the floral structure of Y ucca proper, seem to necessitate their separation from that genus, and the provision for them of a new genus, which is dedicated to my little son, Sam Farlow Trelease, who, in the springs of 1900 and 1902 accompanied and materially aided me in a field study of both species of this genus and of the Mexican and Central American Yuccas. 
The species may be differentiated as follows :-

Perianth-tube conical, under $10 \mathrm{~mm}$. long.

S. Faxoniana. Perianth-tube 12 to $25 \mathrm{~mm}$. long.

S. Carnerosana.

\section{s. Faxoniana Trelease.}

Yucca australis Trelease, Rept. Mo. Bot. Gard. 4:190. pl. 4, 5.Coulter, Contr. U. S. Natl. Mus. 2 : 436, in part.

Y. macrocarpa Sargent, Gard. \& Forest. 8 : 301, 305. f. 42. 9: 1G4., Siiva. 10 : 13. $p l .499$.

Arboreous, 1.5 to $5 \mathrm{~m}$. high, .3 to $.6 \mathrm{~m}$. thick, simple or few branched at top. Leaves 50 to $75 \mathrm{~mm}$. wide, 1 to $1.25 \mathrm{~m}$. long, openly concave to the end, shagreen-scabrid only on the dorsal angles if at all, coarsely fliferous but at length with only a few persistent short pectinate threads near the apex and a cobwebby mass of detached fibers at base. Panicle short stalked, broadly pyramidal, rather loosely branched, with very large persistent at length brittle white bracts. Flowers expanding 50 to $100 \mathrm{~mm}$., white; perianth tube scant $10 \mathrm{~mm}$. long. Fruit oblong-ovoid, 25 to 75 $\mathrm{mm}$. long and $25 \mathrm{~mm}$. in diameter. - Plates 69-71. 78, f. 2. 81, f. 11 .

About Sierra Blanca, Texas, and presumably extending southwards into Mexico. - Plate 94, f. 2.

Travelers who pass Sierra Blanca, in western Texas, by daylight, are usually interested in the scattering forest of low Yucca-like trees covering the surrounding country, a number of which are planted about the section-house and in what was formerly a very attractive collection of succulents at the railroad station.

In the absence of type material or any collections from the type localities, these trees have been considered to represent the Yucca baccata macrocarpa of Torrey, and, under the name $Y$. macrocarpa or its partial synonym $Y$. australis, are described and figured in several places. Associated with them are numerous specimens of $Y$. radiosa and, in smaller numbers, the true $Y$. macrocarpa of the great bend of the Rio Grande, which, as has been shown above, is a well-marked species and preserves all of the floral characters of a true Yucca; and, as indicative of their probable range to the southward, it may be mentioned that they are accompanied by Agave applanata, which, in its typical form, is not known elsewhere in the United States. 
As it occurs from a little way east of Sierra Blanca to the vicinity of Malone, this tree is usually 2 or $3 \mathrm{~m}$. high, rarely reaching 5 meters, and the thin-barked stem, which may reach a diameter of about half a meter, very rarely branches, though occasionally one or two ascending branehes are produced. Well developed plants, even if small, differ conspicuously from those of Yucca macrocarpa in their rounder head and the usually greater number of their spreading leaves, which, smooth or at most slightly roughened on the occasional dorsal angles, are of a crabapple green, openly concave to the very short stout spine, and though at first coarsely filiferous, later have only a few short pectinate thickish fibers toward the tip, while the remainder become detached to the base, where they remain in a loosely cobwebby mass between theleaves, which in age become reflexed and normally persist as a thatch on the trunk even to its base. On vigorous plants the leaves attain a width of $75 \mathrm{~mm}$. and a length of $1.25 \mathrm{~m}$.

This species, which is well described by Professor Sargent, under the name Yucca macrocarpa, I take pleasure in dedicating to Mr. C. E. Faxon, whose excellent figures of it in the Silva faithfully represent its technical characters.

\section{S. Carnerosana Trelease.}

A simple or rarely slightly branched tree, 1.5 to $6 \mathrm{~m}$. high, at length $.7 \mathrm{~m}$. in diameter. Leaves as in the last. Panicle on a stout whitebracted stalk, densely branched close above the leaves, glabrous or exceptionally tomentose. Flowers expanding 75 to $100 \mathrm{~mm}$., the cylindrical tube 12 to $25 \mathrm{~mm}$. long. Fruit oblong, 50 to $75 \mathrm{~mm}$. long, $40 \mathrm{~mm}$. in diameter: seeds 7 to $9 \times 8$ to $10 \mathrm{~mm}$. - Frontispiece to article and plates $72-75$. 76, f. 1. 77. 81, f. 12. 83, f. 2 .

Northeastern Mexico, from the Carneros pass to about Catorce and Cardenas. - Plate 94, f. 2.

Some years since, Mr. C. G. Pringle made eharacteristically excellent herbarium specimens of a tree which forms large forests about Carneros, Mexico, which were distributed as doubtfully representing a variety of $Y$ ucca 
baccata. These specimens (nos. 2841, 3912), represent another species of Samuela, which, from near the city of Saltillo extends southwards, on the mountain slopes and in the higher valleys, to some distance below the Tropic of Cancer, and is especially abundant in the higher valleys about Carneros pass, where the Mexican National railroad crosses the mountains south of Saltillo, and about Las Tablas on the Tampico branch of the Mexican Central.

Like the preceding species, this is a low round-headed tree, very rarely bearing one or two short branches at the apex, and thus in marked contrast with the branched shorter-leaved $Y$. australis which accompanies it in small numbers about Carneros and elsewhere. The leaves vary considerably in thickness, and the thinner ones are usually a little plicate though they are still thick and rigid. The very thick fibers of the leaves distributed by Mr. Pringle are exceptional. The axis of inflorescence, which, though usually erect, is sometimes arched over by the weight of the enormous panicle, is unusually succulent and devoid of fiber, so that a stalk as thick as one's wrist can be severed by a single cut of a pocket-knife. A striking feature of both species of the genus, but particularly marked in S. Carnerosana, is the compact depressed bud, as much as $100 \mathrm{~mm}$. in diameter, in which each branch of the panicle ends until blooming is far advanced. Even from a distance, the pure waxen-white fragrant flowers, which remain expanded to an unexpected degree during the daytime, are marked by their cylindrical tube which gives them the appearance of those of Polianthes, though the ovary is free from the perianth, as in other Liliaceae. The fruit of both species, like that of the baccate Yuccas of the southwest, is usually greenish-yellow, though sometimes tinged with red or purple, and the soft sweet pulp is pale. 


\section{ECONOMIC USES.}

In contrast with the Aloineae, the Yucceae possess very fibrous leaves comparable with those of the agavoid Amaryllidaceae, and local use is made of the fiber* almost everywhere that the plants grow. In the southeastern United States, and as far west as the Indian Territory, the leaves of species of Yucca of the filamentosa group, commonly called " bear-grass," are much used for domestic purposes such as making seats for chairs and especially hanging meat, for which they are so much prized in the country that the plants are commonly tolerated as weeds in cultivated fields from which other wild plants are eradicated. In Mexico and our southwestern states the fiber of several of the baccate species is crudely cleaned and put to various local uses, cordage included. $\dagger$ The long leaves of " palma loca" ( $Y$. Treculeana), with coarse fiber, and "izote" ( $Y$. Schottii Jaliscensis), with fine fiber, are apparently of considerable use in this manner, respectively in the eastern and western parts of Mexico. About the Carneros pass, where it is very abundant, Samuela Carnerosana is similarly used, and Dr. Millspaugh informs me that Mesperaloe funifera is reported as planted for its fiber about Bustemente, in the Mexican state of Nuevo Leon. The fiber of Hesperoyucca is said by Palmer $(l . c$.$) to be fine and excellent. Cleaning$ the fiber of all of these plants appears to be attended with the general difficulties that make the commercial preparation of Agave fibers unsatisfactory, but I have seen machinecleaned fiber of Yucca australis that appeared fairly good, and it may be that notwithstanding its shortness the fiber of these abundant large palma trees of the Mexican tableland will ultimately be used in quantity for the cheaper kinds of bagging, etc.

* See Naudin, Rev. Hort. 1855 : 141-9. - Porcher, Resources of So. Fields and Forests. 530-1.

† Palmer, Amer. Journ. Pharmacy. 50: 586. 
The trunks of the species of Yucca, Clistoyucca and Samuela are occasionally used for palisade construction, and in the Carneros pass I have seen houses built almost entirely of material obtained from $S$. Carnerosana, - the walls of palisade-like trunks set on end, and the roof thatched with the leaves. Attempts have been made to use the fiber of Clistoyucca for paper-pulp, ${ }^{*}$ of which a fair grade can be made notwithstanding the gumminess of the tissues; and the trunks have sometimes been turned into coarse veneers for wrapping bottles, etc., as is commonly done with soft dicotyledonous woods like the cottonwood.

The group generally seems to possess the saponifying properties of the Agaves, so that the stems and root stocks are not infrequently used as amoles, $\ddagger$ and a considerable quantity of vegetable soap is claimed to be made from $Y$. baccata, $Y$. glauca, and, judging from illustrations in advertising matter, $Y$. radiosa.

Notwithstanding their stiff-pointed leaves, the species which grow in the southwestern grazing country are attractive to cattle in the flowering season, and the animals often display some dexterity and no little courage in riding down the smaller trees or otherwise getting at their succulent flower-clusters, which are further gathered and carried in to be fed to sheep and other animals in some cases, as, for instance, in the Carneros pass, where I have seen large cart loads of the great panicles of Samuela Carnerosana being taken to the hamlet for this purpose. In their early stages, too, the inflorescence of Yucca, Hesperoyucca and Samuela is said to be either boiled or roasted and used for human food or even eaten raw. $\ddagger$ Like the crowns of " sotol" (Dasylirion), the nearly fiberless trunks of the southern Samuela are decorticated or splitopen so that they can be eaten by stock.

* Palmer, l. c.-Shinn, Amer. Agriculturist. 1891: 689. - Land of Sunshine. $10: 1$, and advertisement.

$\dagger$ See Palmer, l. c.-

$\ddagger$ See Palmer, l. c. - The Garden. 24: 104, - from N. Y. Tribune. 
As a rule, the fruits of the baccate species of $Y u c c a$ and of Samuela are promptly eaten by birds, rats, etc., but domesticated animals are said to like them, and, being quite sugary, they are enjoyed by the Indian and Mexican children, who commonly call them figs or dates. All that I have tasted possess, in combination with their sweetness, a characteristic bitterness, which makes them somewhat unpalatable, and those of the Rocky Mountain and Mexican region possess a rather viscid pulp which renders them unpleasant to handle when broken. My friend Mr. Burbidge has compared the fruit of Yucca aloifolia with blackcurrant jam with a little admixture of quinine,-its purple color no doubt strengthening the suggestiveness.

The seeds of the baccate species are said to be purgative, though Palmer ( $l . c$.) says that the seeds of Clistoyucca and Hesperoyucca are ground and eaten, either raw or as "mush;" and Gambold (Amer. Jour. Sci. 1819: 251 ) states that the pounded roots are used as a fish poison. It would be interesting to have their active principles determined.

All of the species, when used in the right way, are of decorative value. $Y$. filamentosa, $Y$. flaccida, $Y$. gloriosa, $Y$. recurvifolia, $Y$. glauca, $Y$. baccata, and $Y$. Harrimaniae appear to be hardy as far north as St. Louis, and $Y$. Treculeana is reported frost-hardy at Angers, France (Garden. 12: 369), but the other species, so far as tested, demand a climate scarcely less mild than that of our southern states, California or the Riviera.

\section{PHYLOGENY AND ECOLOGY.}

Little can be said as to the origin or mode of specialization of the Yucceae. They are characteristic xerophytes, even those which grow in the moist climates frequently having a preference for dry places, such as sand dunes. Their underground parts are frequently fleshy and very tenacious of life, their stems hold a considerable amount 
of moisture, and their leaves are well guarded against undue transpiration. Like other arboreous Liliaceae, their larger representatives produce the impression of being the culmination of a vegetative type perhaps formerly of wide distribution, but now barely able to hold its own except in desert regions where competition between plants is less than elsewhere, while structural adaptation enables them to endure the rigors of this last resort, - in a sense, therefore, recalling the bald cypress (Taxodium) among conifers, which for similar reasons has betaken itself to the other extreme of deep swamps. I know of no ecological explanation of the filiferous shedding of the leafmargins of many species.

The dissemination arrangements of the Yucceae are of the more highly specialized types. Many species, constituting the genus Hesperaloe, Hesperoyucca, and the capsular section of $Y u c c a$, are wind-disseminated, with thin flat seeds lifted from time to time out of the suberect capsules by gusts of wind. In Clistoyucca the indehiscent mature fruit is spongy and light and apparently adapted to being blown about by the desert winds after the manner of bladder-fruits or tumble-weeds. Yucca gloriosa and $Y$. recurvifolia possess fruits which do not dehisce, though their seeds are thin and flat; nor do they become edible in ripening, but dry to a firm almost wooden consistency, out of harmony with any usual mode of dissemination. All of the baccate species of Yucca and the two species of Samuela have fleshy edible fruits at maturity, and their abundant endosperm suggests an adaptation to the dry regions, in which all of them, so far as known, live, with the exception of $Y$. aloifolia, and, perhaps, $Y$. elephantipes. That they have been derived from thin-seeded capsular species seems more probable than the reverse, and the coreless fruit of the seaside $Y$. aloifolia suggests its independent fruit specialization rather than a genetic con- 
nection with the desert species, which possess a firm, parchment-like core immediately about the seeds.

The pollination relations of nearly all of the group are among the most peculiar and exclusively restricted thus far discovered. Hesperaloe secretes much nectar and appears adapted to birds, as are the Cape aloes, to which it bears no inconsiderable resemblance in its flowers. The other genera are sparingly if at all nectariferous, though all have septal glands, which are rather small in Clistoyucca, but very large in the others. Yucca aloifolia, again in an exceptional way, appears to be freely self-fertile, but selfseeding is very unusual with all of the other species of this genus, as it appears to be with Hesperoyucca, Clistoyucca and Samuela. These, so far as known, depend for their pollination upon small moths belonging to the tineid genus Pronuba, of which one species ( $P$. synthetica) is known only in connection with the single species of Clistoyucca, one ( $P$. maculata, and its variety aterrima), with the single species of Hesperoyucca, and the only other known species ( $P$. yuccasella) accompanies the various species of Yucca across the continent and has a known north and south range from the great bend of the Missouri river to central Mexico. These moths are not known to feed, in the larval stage, on anything but the developing seeds of the plants named; so that the mutual dependence of moth upon plant and of plant upon moth appears to be absolute, - no doubt, taken in connection with the other ecological peculiarities of the yuccoids, a fact of the greatest suggestiveness, but the bearing and meaning of which has as yet escaped both botanists and entomologists. That the flowers were formerly pollinated otherwise appears to be indicated by the presence of nectar-glands, which now appear to be useless.

The long perianth tube of Samuela, - a type of structure usually connected with pollination by some insect of corresponding tongue-length, for which the nectar is thus 
kept from shorter-tongued insects, - is so closely applied about the lower part of the ovary, as, apparently, to make it impossible for any insect to reach the bottom of the latter, with even a very slender tongue. Though the actual pollination of this genus is yet to be observed, it is effected by Pronuba yuccasella, at least in S. Faxoniana, in the flowers of which pollen-laden females of the moth were discovered by my son and myself in April, 1902, and the only explanation of the highly specialized tubular perianth I can suggest is that, restricting the access of the ovipositing moths to the upper half or two-thirds of the ovary, it may limit the number of eggs that they can lay in a given pistil, to the advantage of the plant.

\section{EXPLANATION OF PLATES.}

Unless otherwise stated, the illustrations are from photographs by the author. Where two illustrations occur on a plate, the upper or left-hand is referred to first.

Frontisplece to article. - Samuela Carnerosana, in the Carneros Pass, Mexico.

Plate 1. - 1, Hesperaloe parviflora, cultivated in San Antonio; $2, H$. parvifiora Engelmanni, cultivated at the Missouri Botanical Garden.

Plate 2. - Flowers of Hesperaloe parviflora Engelmanni, natural size, from the Missouri Botanical Garden.

Plate 3. - Hesperaloe funifera, at Peyotes, Mex.

Plate 4. - 1, Hesperaloe funifera, capsules from Peyotes, natural size; 2, Hesperoyucca Whipplei, capsules from Arrowhead Springs, Cal., natural size.

Plate 5. - Hesperoyucca Whipplei, and its flowers, reduced, at the summit of the Cajon Pass, California.

Plate 6. - Clistoyucca arborescens, at Hesperia, California.

Plate 7. - Clistoyucca arborescens, flowers, reduced, and fruit, natural size, at Hesperia, Cal.

Plate 8. - Yucca filamentosa, at Sanford, Fla., and flowers, natural size.

Plate 9. - Yucca filamentosa bracteata, cultivated at Brunswick, Ga.

Plate 10. - Yucca filamentosa concava, in sand dunes, Isle of Paims, S. C.

Plate 11. - Yucca filamentosa media, cultivated in Tower Grove Park, St. Louis. Photographed by P. T. Barnes.

Plate 12. - Partly grown fruit of Yuccas cultivated in the Missouri 
Botanical Garden, natural size. - 1, Y. filamentosa; 2, Y. flaccida glaucescens.

Plate 13. - Yucca flaccida glaucescens, cultivated in the Missouri Botanical Garden. - Producing racemose secondary inflorescences, in addition to the central panicles.

Plate 14. - Iucca flaccida glaucescens, cultivated at the Missouri Botanical Garden, showing thermotropism of inner leaves.- 1, Normal position of leaves, at a temperature slightly above the freezing point; 2, Leaves inrolled, at $26^{\circ} \mathrm{F}$.

Plate 15.- Fucca flaccida glaucescens, cultivated at the Missouri Botanical Garden. - Photographed by P. T. Barnes.

Plate 16. - Yucca flaccida, near Anniston, Ala.

Plate 17.-Capsules, natural size.-1, Yucca flaccida glaucescens, cultivated at the Missouri Botanical Garden; 2, Y. tenuistyla, Industry, Tex., Lindheimer.

Plate 18. - Fucca tenuistyla, near Sealy, Tex.

Plate 19. - Iucca tenuistyla from near Sealy, Tex. Small sized flowers, natural size. - Photographed by P. T. Barnes.

Plate 20. - Iucca constricta. - 1, Cultivated at the Missouri Botanical Garden from Seward Co., Kas.; 2, Near Uvalde, Tex.

Plate 21. - Capsules, natural size. - 1, Yucca constricta, Cline, Tex.; 2, Y. radiosa, Benson, Ariz.

Plate 22. - Fucca radiosa, at Benson, Ariz. Fruiting plants and an exceptionally symmetrical young plant.

Plate 23. - 1, Yucca angustissima, a type sheet in the Engelmann herbarium; 2, Yucca glauca, near Albuquerque, N. M.

Plate 24. - Capsules, natural size. - 1, Yucca angustissima, from near the Grand Cañon, Ariz. ; 2, Yucca glauca, from Manitou, Col.

Plate 25. - Yucca glauca, cultivated in the Missouri Botanical Garden.

Plate 26. - Yucca glauca stricta, cultivated in Tower Grove Park, St. Louis, from Seward County, Kas.

Plate 27.-Flowers of Yucca glauca stricta, natural size, from the preceding. - Photographed by P. T. Barnes.

Plate 28. - Yucca Harrimaniae, at Helper, Utah.

Plate 29. - Yucca Harrimaniae, Helper, Utah, - Capsules, natural size.

Plate 30. - Yucca Arkansana, near Fort Worth, Tex.

Plate 31. - Yucca Arkansana, near Dallas, Tex., fruiting plants.

Plate 32. - Yucca Louisianensis. - 1, Near Jefferson, Tex.; 2, Near Texarkana, Tex.

Plate 33. - Yucca Louisianensis, Hughes Springs, Tex.

Plate 34. - Yüca Louisianensis, Hughes, Tex.-1, Form with slenderer, paler style; 2 , Form with very tumid dark green style, slightly reduced.

Plate 35. - Yucca rigida, near Picardias, Mex.

Plate 36. - Capsules, natural size. - 1, Yucca rigida, from Picardias, Mex.; 2, Fucca rostrata, from Peyotes, Mex. 
Plate 37.- Yucca rupicola? Aberrant sheet of Wright, no. 1909, in the Torrey herbarium.

Plate 38. - Yucca rupicola,- the more normal Gray herbarium sheet of Wright, no. 1909.

Plate 39. - Yucca rupicola. - 1, Flowering plant, on limestone hills a few miles west of Fort Worth, Texas; 2, Flowers, slightly reduced, of plant cultivated by Mr. J. Reverchon, from same locallty.

Plate 40. - Yucca rostrata, at Peyotes, Mex. - Flowering plants.

Plate 41. - Yucca rostrata, at Peyotes, Mex. - The upper figure showing the lozenge-shaped leaf-scars.

Plate 42. - Yucca rostrata, at Peyotes, Mex. - fruiting plants. - The foreground is occupied by Agave heteracantha.

Plate 43. - Yucca gloriosa, in the sand dunes of Tybee Island, Ga.

Plate 44. - Yucca gloriosa, Tybee Island, Ga. - 1, Smooth-barked trunk, with roots, exposed by the shifting of the sand; 2, With partly grown fruit, photographed in May.

Plate 45. - Yucca gloriosa minor, cultivated in the Missonri Botanical Garden. - At the left are $Y$. aloifolia, with narrow leaves, and $Y$. elephantipes, with broad more flexible leaves.

Plate 46. - 1, Yucca gloriosa superba, fruit and cross section, natural size, - cultivated in Washington, D. C. (Schott); 2, Yucca recurvifolia, fruit, natural size, cultivated at Bluffton, S. C. (Mellichamp, in 1901).

Plate 47. - 1, Yucca recurvifolia (2 m. high), cultivated in the National Cemetery, Vicksburg, Miss.; 2, Yucca flexilis Hildrethi, escaping, at St. Augustine, Fla., photographed in May.

Plate 48. - "Yucca De Smetiana," cultivated in the Yucca tower of the Missouri Botanical Garden.

Plate 49. - Yucca aloifolia. - 1, Associated with Ipomoea Pes-Capreae, on the dunes of South Beach, St. Augustine, Fla.; 2, Overgrown with Smilax, on the dunes of Tybee Island, Ga.

Plate 50. - Yucca aloifolia Menandi, type plant cultivated at the Missouri Botanical Garden. - Photographed by P. T. Barnes.

Plate 51. - Yucca elephantipes. - 1, A large tree, at El Florido, Guatemala; 2, The dilated base of a tree, at Chinautla, Guatemala.

Plate 52.- Yucca Treculeana. - 1, In flower, cultivated at C. P. Diaz, Mex.; 2, In fruit, near Peyotes, Mex.

Plate 53. - Yucca Treculeana canaliculata. Cultivated in the Alamo Plaza, San Antonio, Tex.

Plate 54.- Yucca Treculeana canaliculata. Cultivated at the Missouri Botanical Garden. - Photographed by P. T. Barnes.

Plate 55. - Yucca Schottii, west of Nogales, Ariz., photographed in August: the second figure, from near the boundary monument in the Sierra del Pajarito.

Plate 56. - Yucca Schottii Jaliscensis. "Izote", in the suburbs of Zapotlan, Mexico, photographed in September.

Plate 57. - Yucca brevifolia. The mixed type-sheet, in the Torrey her- 
barium. The leaves are representative of $Y$. brevifolia, and the inflorescence, apparently, of $Y$. Schottii.

Plate 58. - Yucca brevifolia, toward the Santa Cruz river, to the northeast of Nogales, Ariz.

Plate 59. - Iucca brevifolia. Tree about 2 meters high, with panicle axis from preceding year, near Nogales, Arizona.

Plate 60.- Tucca australis. The original sheet of Thurber's collection from Parras, Mex., in the Torrey herbarium.

Plate 61. - Yucca australis. - 1, In fruit, at Parras, Mex.; 2, In flower, near Topo Chico, Monterey, Mex.

Plate 62. - Yucca valida. Old hedgerows, near Durango, Mex.

Plate 63. - Yucca valida, near Gutierrez, Mex.

Plate 64. - Iucca valida. - 1, Near Gutierrez, Mex., with Opuntia leucotricha in the foreground; 2, Near Camacho, Mex.

Plate 65. - Fucca valida, near Gutierrez, Mex. - The lower part of the trunk, some years before, had been decorticated without killing the tree, over the lower part of which a new bark has formed.

Plate 66. - Yucca valida. Flowers, somewhat rednced, from near Gutierrez, Mex.

Plate 67. - Yucca valida. Type sheet, from San Gregorio, L. Cal., in the Brandegee herbarium.

Plate 68. - Yucca baccata, in the Grand Cañon, Ariz. - The fruit is 20 cm. long.

Plate 69. - Yucca baccata. Fruit of the preceding, natural size (foreshortened), showing the basal disk. - Photographed by P. T. Barnes.

Plate 70. - I rucca macrocarpa. Flowering plant, near Sierre Blanca, Texas.

Plate 71. - Yucca macrocarpa. Fruiting plants, in the type region, in the great bend of the Rio Grande.

Plate 72. - Iucca Mohavensis, at Drake, Ariz. - The right-hand figure has a very characteristic plant of Fouquiera in the foreground.

Plate 73. - Samuela Faxoniana, near Sierra Blanca, Tex. - Characteristic round-headed trees.

Plate 74. - Samuela Faxoniana, a partly sterile fruiting plant, with persistent bracts, and a plant beginning to bloom, near Sierra Blanca, Texas.

Plate 75. - Samuela Faxoniana. Leaf tips and partly grown fruit (showing the fleshy base and short split tube of the perianth), from Sierra Blanca, Tex., natural size.

Plate 76. - Samuela Carnerosana, in the Carneros Pass, Mex. Full blown trees, and the foliage head of a young plant.

Plate 77.-- Samuela Carnerosana. Flowering and fruiting trees in the Carneros Pass, Mex. - The partly sterile inflorescence is conspicuous even in fruit, because of its persistent large bracts.

Plate 78. - Samuela Carnerosana in the Carneros Pass, Mex. - 1, Fruiting tree; 2, Early stage of flowering, showing the large bracts and the buds in which the panicle branches at first end. 
Plate 79. - Samuela Carnerosana, from the Carneros Pass, Mex., natural size. - 1, Inflorescence bud; 2, Flower, with nearer part of perianth removed, and half grown fruit with the persistent split perianth tube upwards of $2 \mathrm{~cm}$. long.

Plate 80. - 1, Samuela Carnerosana, in the Carneros Pass, Mex.; 2, Yucca flaccida, var., cultivated at the Missouri Botanical Garden. Both reduced. - The perianth differences of the two genera are well shown.

Plate 81. - Samuela Carnerosana, in the Carneros Pass, Mex. - 1, A trunk decorticated by slashing it on the two sides and tearing the leaves down, exposing the pulpy interior for stock to feed upon; 2, A fruit, somewhat reduced, showing the split dried perianth tube.

Plate 82. - Yucca elephantipes, at Chinautla, Guatemala, and Samuela Faxoniana, at Sierra Blanca, Texas. Flowers, reduced about one-third.

Plate 83. - Seeds of Yuccas, natural slze.*-1, $Y$. filamentosa concava, Isle of Palms, S. C. (Trelease); 2, Y. flaccida glaucescens, cultivated at the Missouri Botanical Garden; 3, I. tenuistyla, Industry, Tex. (Lindheimer); 4, $\boldsymbol{Y}$. constricta, Uvalde, Tex. (Trelease); 5. I. radiosa, Presidio, Tex. (Trelease); 6, $Y$. angustissima near Grand Cañon, Ariz. (Trelease); 7, Y. Arkansana, New Braunfels, Tex. (Lindhelmer); 8, $\dot{Y}$. Louisianensis, Atoka, Ind. Ter. (Butler); 9, Y. glauca, N. W. Missouri (Bush); 10, Y. Harrimaniae, Helper, Utah (Trelease).

Plate 84. - Seeds of Yuccas, natural size. - 1, Y. rigida, Picardias, Mex. (Trelease); 2, Y. rupicola, New Braunfels, Tex. (Lindheimer); 3, I. rostrata, Peyotes, Mex. (Trelease); 4, Y. gloriosa superba, cultivated in Washington, D. C. (Schott); 5, Y. recurvifolia, cultivated at Bluffton, S. C. (Mellichamp); 6, $X$. aloifolia, Bluffton, S. C. (Mellichamp); 7, Y. elephantipes, cultivated at the Missouri Botanical Garden; 8, Y. Treculeana, New Braunfels, Tex. (Lindheimer).

Plate 85. - Seeds of Yucceae, natural size. - 1, Tucca Schottii, Pinal Mts., Ariz. (Pringle); 2, $\boldsymbol{Y}$. australis, Parras, Mex. (Trelease); 3, Y. valida, Gutierrez, Mex. (Trelease); 4, $Y$. baccata, Grand Cañon, Ariz. (Trelease); 5, $Y$. macrocarpa, near Presidio, Tex. (Trelease); 6, $Y$. Mohavensis, Drake, Ariz. (Trelease); 7, Hesperaloe parviflora, Texas (Wright); 8, H. funifera, Haclenda de Angostura, Mex. (Pringle, no. 3911); 9, Hesperoyucca Whipplei, Arrowhead Springs, Calif. (Trelease); 10, Clistoyucca arborescens (Palmer); 11, Samuela Faxoniana, Sierra Blanca, Tex. (Trelease); 12, S. Carnerosana, Carneros Pass, Mex. (Trelease).

Plate 86. - Germination of Yuccas, natural size. - 1, Y. radiosa; 2, $Y$. macrocarpa.

Plate 87. - Germination of Yucceae, natural size. - 1, Clistoyucca arborescens; 2, Samuela Carnerosana.

Plates 88-99. - Geographical distribution of Yucceae. - Stations noted by the author are indicated by $a$, , and the general range known to him is shown by horizontal shading. Many gaps require filling.

* The figures in this and the following plates are numbered from left to right in the several rows, beginning with the uppermost. 


\section{N D E X}

\section{(Synonyms in Parenthesis.)}

Agave applanata 117

Cubensis (114)

geminiflora 114

funifera (36)

heteracantha $127, p l .42$

Aloe Americana, Comm. $(88,89,91)$

Juccae follis, Sloane. (88)

purpurea levis, Munt. (91)

y uccae follis, Pluk. (89)

Aloe yuccaefolia $(30,31)$

Aloes Floridana, Plak. (88)

Aloineae 27, 28

Astelia 27, 28

Beaucarnea (27) longifolla (115)

Chaenoyucca 43, 44, 46

Clistoyucca $29,41,123,124$

arborescens 41, 103, 121, 122, 1:25, 129. pl. $6,7,85, f .10,87, f .1,8 s$

Cohnia 28

Cordyline 27, 28

Cordyline folils pungentibus, Van

Royen $(72,89)$

Dasylirion 27, 28, 114, 121

acrotrichum 114,115

aloefolium $(103,105)$

graminlfolium 40, 114

longifolium (115)

pitcalrnifollum (115)

serratifollum 115

Dracaena 27, 28

Lhrenbergli (94)

Fintelmannl (94)

Lenneana (94)

Lennei (94)

yuccoides (94)

Dracaeneae 27,28

Dracaenoideae 28

Draconl arborl affinis, Baub. (91)

Euyucca 43

Fouquiera 128. $p l .72$

Furcraea Bedinghausil 43, 106

Cubensis 114

geminlspina 114
Hechtia glomerata 115

Herreria 27, 28

Hesperaloe 27, 28, 29, 31, 123, 124

Davyl $(36,37)$

Engelmannl $(33,36)$

funifera $29,36,120,125,129 . p l .3,4$, f. $1,85, f .8,96$

parviflora $29,30,125,129 . p l .1, f .1$, $8 \tilde{8}, f .7,88$

- Engelmann1 33, 125. pl. 1, f. 2, 2 yuccaefolia $(3 n, 33)$

Hesperocallis 27, 28

Hesperoyucca 29, 38, 123, 124

Whipple1 39, 120, 121, 122, 125, 129. $p l$. $4, f .2,5,85, f .9,88$

Heteroyucca $43,45,71$

Iucca, Park. (72) Perana, Gerarde (72)

Peruana, Johnson (72)

Juca Americana, Munt. (47) gloriosa, Munt. (72)

Lilla regia (105)

Lillum regium (105)

Milligania 27, 28

Nolina 27, 28, 71 longlfolla 69,115

Nolineae 28

Pronuba maculata 124

- aterrima 124

synthetica 124

yuccasella $82,85,87,89,124,125$

Roezlia bulblfera (105)

regla (105)

Samuela 29, 116, 122, 123, 124

Carnerosana 117, 118, 120, 121, 125, 128, 129. Frontispiece, $p l$. 76-79, $80, f .1,81,85, f .12,87, f .2,98$

Faxonlana $112,117,125,128,129 . p l$. $73-75,82$, f. 2,85, f. 11,98

Sarcoyucca $43,45,88$

Tacori, Clus. (91)

Taxodium 123 


\section{Xanthorrhoea 71}

Yuca, Park. (72)

follis Aloes, Banh. (72)

folils flamentosis, Moris. (47)

Perana, Gerarde. (72)

Yucca 27, 28, 29, 42, 120-124. pl. 99.

acaulis (114)

acrotrtcha (114)

acumlnata $(72,74,79)$

acntifolla (74)

agavoldes (96)

alba-spica $(54,57)$

$X$ albella 115

albosplca $(57,82,105)$

aletriformis (114)

aloefolia versicolor (90)

aloifolia (39) $45,81,82,84,86,87,88$, 89,90 (94) $110,116,122,123,124,127$,

129. $p l .45,49,84$, f. 6,95

- arcuata 90,92

- Menandi 90

- tenulfolia 90

- conspicua 89, 92

- Draconis 89,91, 95

- consplcua 89

- flexifolla (92)

- marginata 89,90

- Menand1 90, 93, 127. pl. 50

- purpurea 89,90

- quadricolor (91)

- roseo-marg!nata (91)

- stenophylla (88)

- tenulfolia 90, 93

- tricolor 89, 91

- varlegata $(82,90)$

- Yucatana 90, 93

$\times$ Andreana 77

angustlfolia $(54,56,60,79,82,83,114)$

- elata (56)

- mollis (63)

- radiosa (56)

- stricta $(61,64)$

angustissima $45,58,126,129 . p l .23$,

f. $1,24, f .1,83, f .6,93$

arborescens $(41,89)$

arcuata (92)

argospatha (96)

argyrophylla (105)

Arkansana 45, 53, 54,55, 62, 63, 126,

129. $p l .30,31,83, f .7,92$

armata (88)

aspera (96)

Atkinsi (90)

australis 46,100, 103, 108-9 (117) 119, 120, 128, 129. pl. $60,61,85, f .2,96$

baccata $46,109(113,119) 121,122,128$, 129. $p l .68,69,85, f .4,97$
Yucca baccata anstralls $(103,105-6,110$, 111,113 )

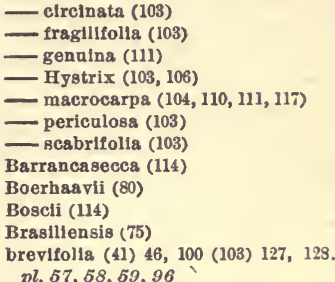

Californica $(39,95)$

canaliculata $(97,105)$

- fllifera (103)

- pendula (97)

$\times$ Carrlerel 74

clrcinata $(103,104,106)$

concava (49)

consplcua (92)

constricta 15,54 (56) 123,123 . $21, f .1,83, f .4,92$

contort3 $(67,96)$

cornuta $(82,9 \%)$

crenulata (88)

$\times$ Deleull 67,7

De Smetiana 45, 87, 127. pl. $4 \$ 3$

$X$ dracaenoldes 77

Draco (91)

Draconis $(88,91)$

- arborescens (41)

elata $(56,58)$

$X$ elegantissima 115

elephantipes $45,71,92,94,123,127$, 129. $p l .4 .5,51,82,84, f .7$

Ellacombel (75)

$\times$ Elmensis 116

Engelmanni (39)

$X$ ensifera 79

ensifolia (80)

exigua (52)

Eylesil (80)

falcata (80)

filamentosa (39) ' $44,46,47(48,49$, $50-53,64) 81,82,83,87,116,120,122$, 125, 126. pl. $8,12,89,91$

- Antworpensis (51)

- aurea elegantissima (48)

- blcolor (48)

— bracteata 47, 48, 125. pl. 9,90

- concava 47, 49, 84, 125, 129. pl. 10 , $82,8.1,90$

- flaccida (49)

- glaucescens $(51,82)$

grandiflora (52) 
Yocea flamentosa laevigata (49)

- latifolla (49)

- major $(115,116)$

- maxima $(48,52)$

— medis 47, 49,125. pl. 11

- patens $47,48 . p l .89$

- puberula (50)

- varlegata $47,48(77)$

Allfera $(103,104-6)$

flaccida $44,49,50,51$ (51) $83,84,116$ 122, 126. pl. 16, 91

_ exigua, 52

- glaucescens, 50, 51, 126, 129, pl. $12-15,17,80, f .2,83, f .2$

- lineata, 50 .

- grandiflora, 51,52

—— exigua, 51

- Integra, 51

_ integra, 52

- lineata 52

- orchloides 50,51

flexilis $45,78,79,81,83,87$

Boerhaavil 79, 80

_ ensifolia 79,80

- falcata (80)

- Hildrethl $79,80,127 . p l .47, f .2$

patens 79, 81

- Peacockil, 79

— semleylindrica 79,80

- tortulata, 79, 80

follis Aloes (72)

follis lanceolatis (47)

follis margine integerrimls (72)

follorum marg. cren. $(89,92)$

fragllifolla $(103,104,106)$

funifer $\$(36,38)$

Ghiesbreghtil (94)

glgantea $42,45,71$

glauca $45(49,52,54,58) 59(75), 82,121$, 122, 126, 129. pl. 23, f. $2,24, f .2$, $25,83, f .9,93$

- mollis (63)

— stricta (55) 61 (64) 126. pl. 26, 27 glaucescens $(51,75)$

- varlegata ( 78$)$

gloriosa $42,45,72,73,74(74-6,79) 81$, $84,85,87,88$ (95) $115,116,122,123$, 127. $p l .43,44,94$

— acuminata (72)

- elegans marginata (78)

- varlegata (78)

- Ellacombel (75)

_ glauca pendula (116)

- glaucescens (75)

- longlfolia, 75, 82

- maculata 76

- marginata (78)

- area (78)
Yucca gloriosa medio.plcta (74)

- med10-8triata 73,74

- minor 73, 74, 80, 127. pl. \pm 5

- mollis $(64,76)$

- nobills 75

- parviflora 75

- obliqua 73,74

- planlfolia (76)

- plicata $73,74,75,82,84$

- maculata 74,76

- superba 74,76

- pruinosa (81)

- recurvata (74)

- recurvifolla (76)

_ fol. var. (78)

- robusta $73,74,75$

—— longlfolla 73

— nobills 73

- rufocincta (78)

— superbs 76, 127, 129. pl. $46, f .1$,

$81, f .4$

- tortulata $(80)$

- tristis (77)

- variegata (78)

graminlfolia $(39,114)$

Guatemalensis (94)

$\times$ Guigllelm 116

Hanburil (60)

Harrimaniae 45, 59, 122, 126, 129. pl. $28,29,83, f .10,93$

Haruckeriana (91)

Helkin $8 i$ (87)

horrida (114)

$\times$ Imperator 116

integerrima (72)

Japonica (105)

$\times$ juncea 79

$\times$ Iaevigata 79,82

Lenneana (94)

$\times$ liliacea (116)

lineata lutea (91)

longlfolia $(75,79,96,115)$

Louigian ensis $45,54,62,64,83,126,129$. pl. $32,33,34,83, f .8,92$

lutescens $(6 \pi)$

macrocarpa $46(98) 110(113,117), 117$, 128-9. pl. $70,71,85, f .5,86, f .2,98$

$\times$ magnifica 116

$\times$ margaritacea 116

$\times$ Masillensls 79

Mazell (98-9)

medio-pleta (91)

Meldengis $(50,51)$

Mexicana $(78,92)$

Mohavengis 46, 110, 112, 113, 128, 129. pl. $72,85, f .6,98$

Mooreana (94)

obliqua $(74,76)$ 
Yucca orchioldes (51)

- major (51)

Ortglesiana $(39,41)$

Parmentleri (105)

parvifiora (30)

patens (81)

pavifiora (30)

Pescockil (79)

pendula $(76,82)$

- aurea (78)

- varlegata (78)

periculosa $(103,104,106)$

Peruans (72)

picta (91)

pitcairnlfolia (115)

plicats $(75,82-3)$

- glancs (75)

plicatllis (75)

polyphylla $(57,103,104,106)$

$X$ praecox 116

Pringlel $(43,105)$

prulnosa (81)

puberula $(49,100)$

quadricolor $(91,93)$

- varlegata (91)

radiosa 45,56 (58) 104, 11i, 121, 126, 129. pl. $21, f .2,22,83, f .5,86, f$. 1,93

recurv8 (76)

- elegantissima (78)

recurvata (97)

recurvifolis $45,48,64,75,76,77,81,82$,

$83,84,86,87,122,123,127,129 . p l .46$,

f. $2,47, f .1,84, f .5,94$

- elegans 77,78

- marginata 77,78

- rufocincta 77, 78

- tristis 77

- variegata 77, 78

revolnts (97)

rigida 45,65 (67) $106,126,129 . \mathrm{pl} .35$, $36, f .1,84, f .1,93$

Roezlil (94)

rostrata $45,68,104,126,127,129 . p l$. $36, f .2,40,41,42,84, f .3,93$

rubescens (115)

rabra (74)

rufoclncta (78)

rupicola $45,67,83,116,127,129 . p l . s 7$, $38,39,84, f .2,93$

— riglda $(65,67)$
Yucca rupicola tortifolia (66-7)

scabrifolia $(103,104,106)$

schldigera (113)

Schottil 16, $98(99,100) 101,103,127$, 128, 129. pl. 55, 57, 85, f. 1,96

_- Jaliscensis 99, 120, 127. pl. 56, 96 semicyllndrica (80)

serratifolia (115)

serrulata (88)

- argenteo-marginata (90)

spinosa (114-5)

stenophylla $(79,114-5)$

Stokesi (91)

$X$ striatula 79

stricts $(61,64)$

- elatior (64)

- Intermedia (64)

$X$ sulcata 74

superbs 76

tenulfolis (93)

tenuistyla 45, 63, 62, 126, 129. pl. 17, f. $2,18,19,83, f .3,92$

Toneliana (105)

tortilis (67)

tortulats (80)

Treculeana 45, 82, 83, 96, $87(99,103)$ $106,112,115,120,122,127,129 . p l .52$, $84, f .8,95$.

- canaliculata $97,127 . p l .53,54$, 25

- glauca (97)

undulata (97)

$\times$ Treleasel 116

tricolor (91)

undulata $(80,97)$

valtda $46,107,128,129 . p l$. 62-67, 85, f. 3,97

Vandervinntana (96)

variafolla (77)

varlegata (90)

versicolor (30)

Virginlana (47)

$\times$ viridl flora 116

$\times$ Vomerensis 116

Whipplel (39)

- glanca (39)

- graminifolla (39)

- vlolacea (40)

Yucatana 93

Yucceae 27, 28

Yuccoldeae 27 



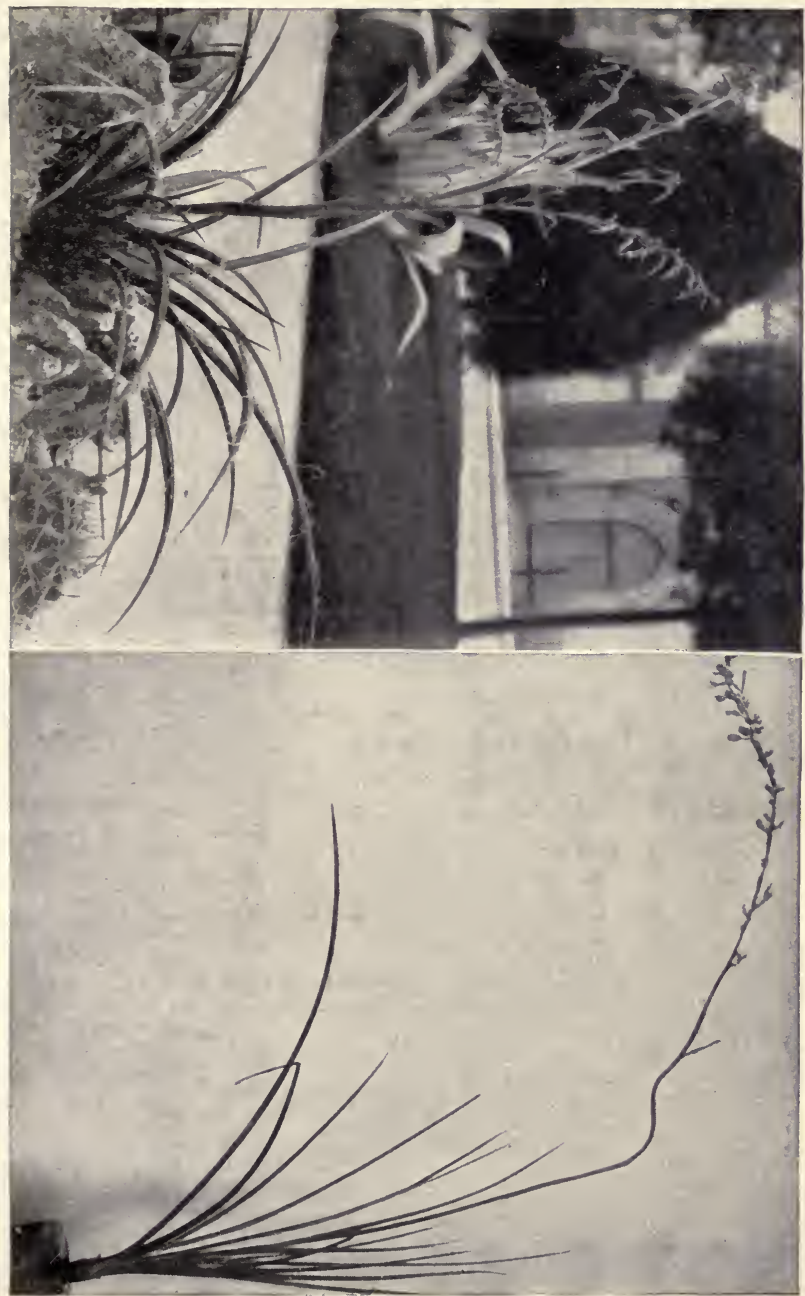





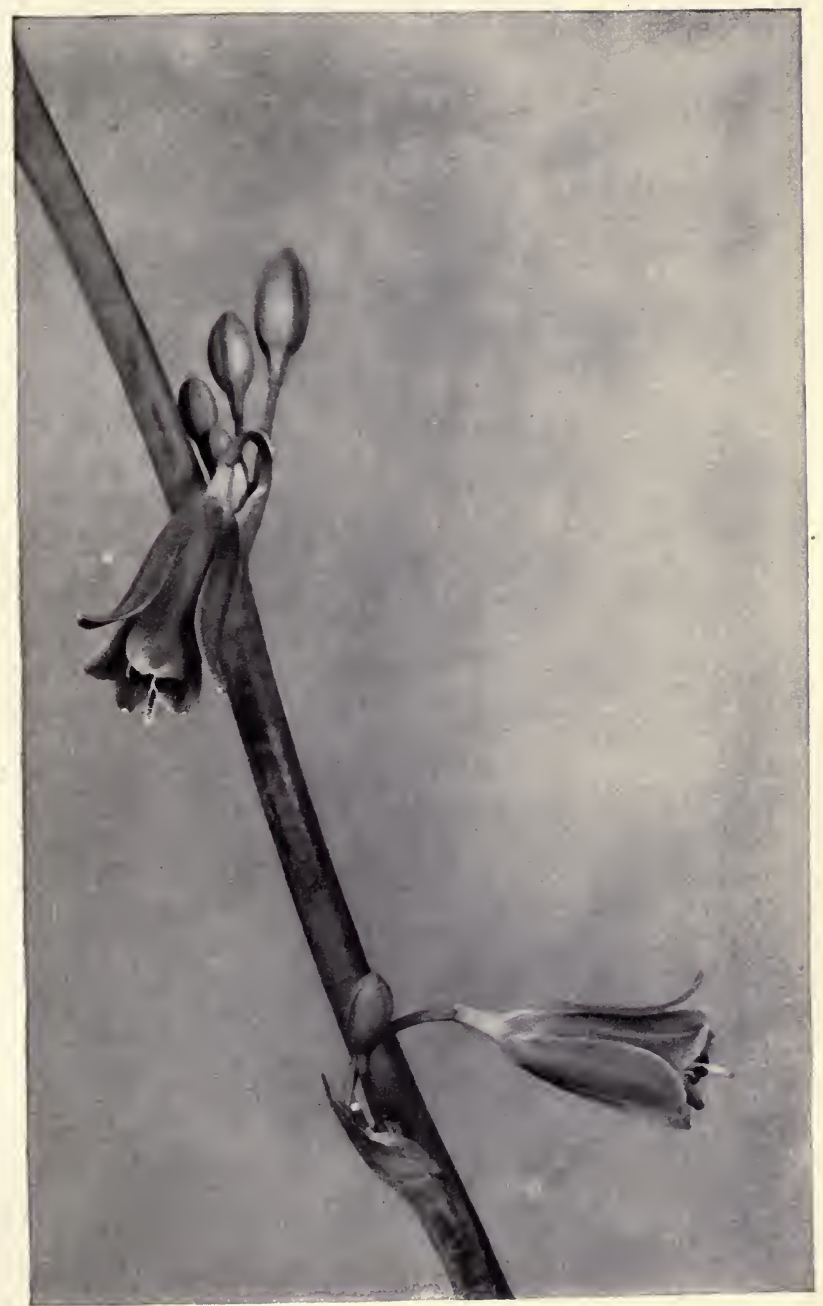

HESPERALOE PARVIFLORA ENGELMANXI. 



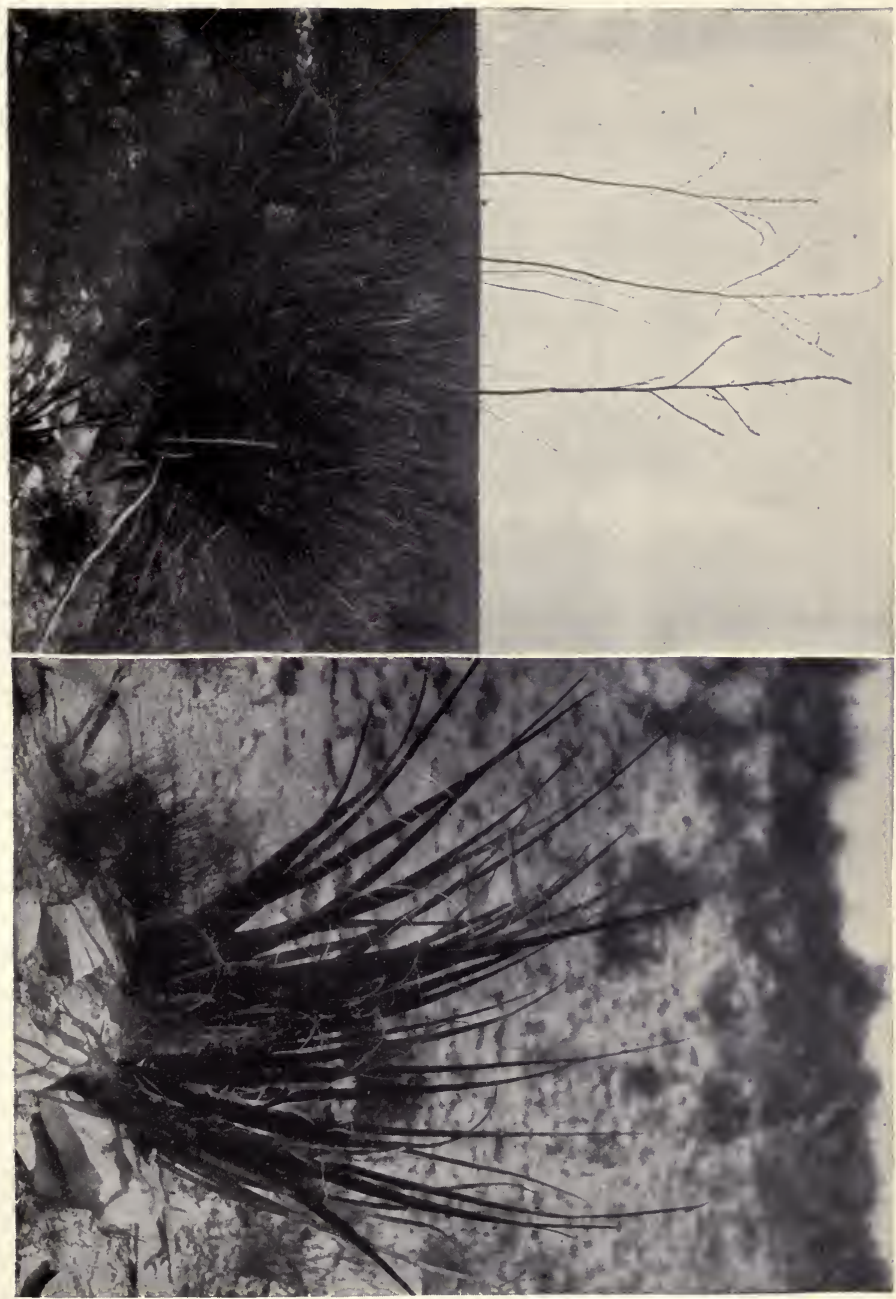





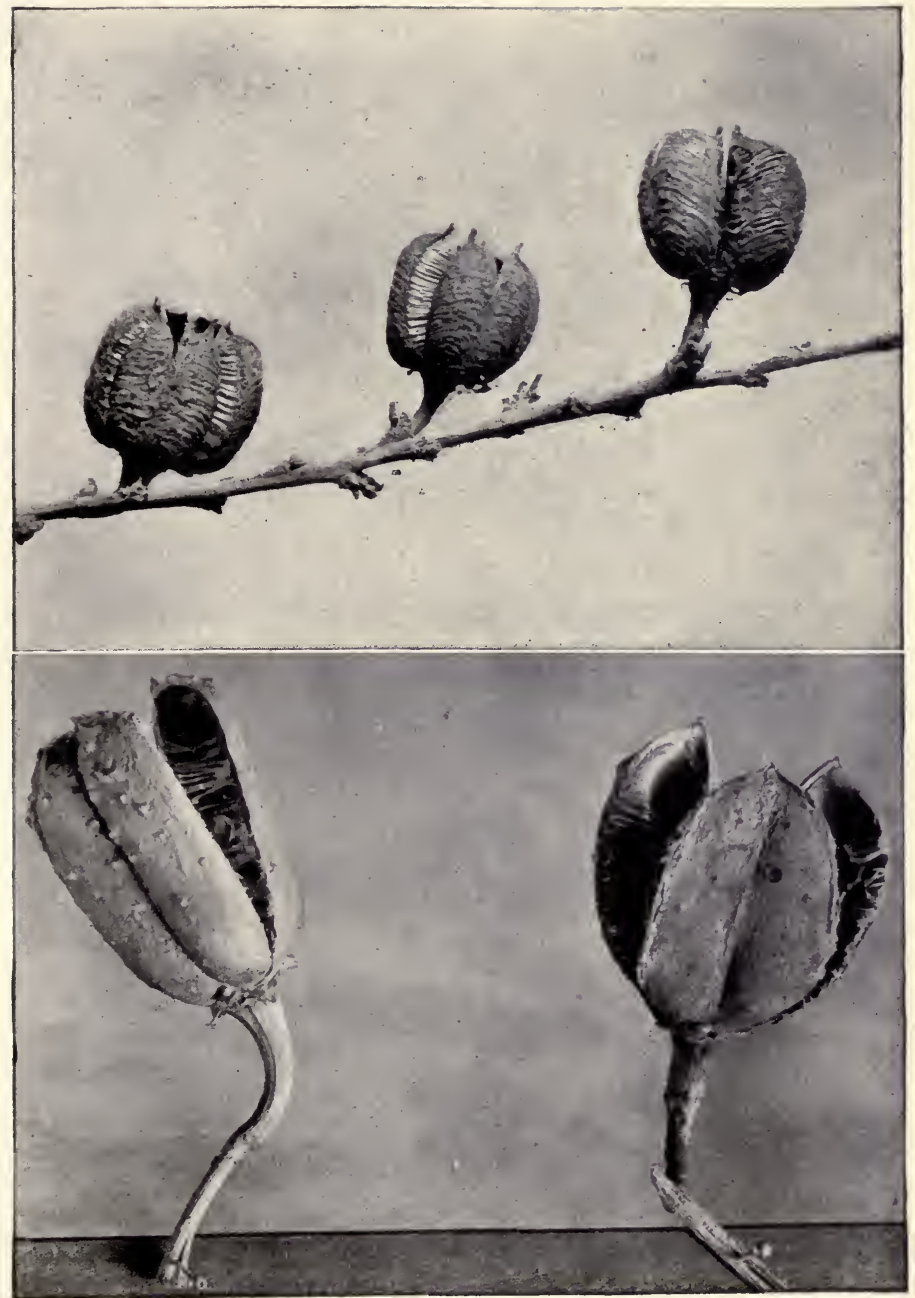

HESPERALOE AND HESPERYOUCCA. 


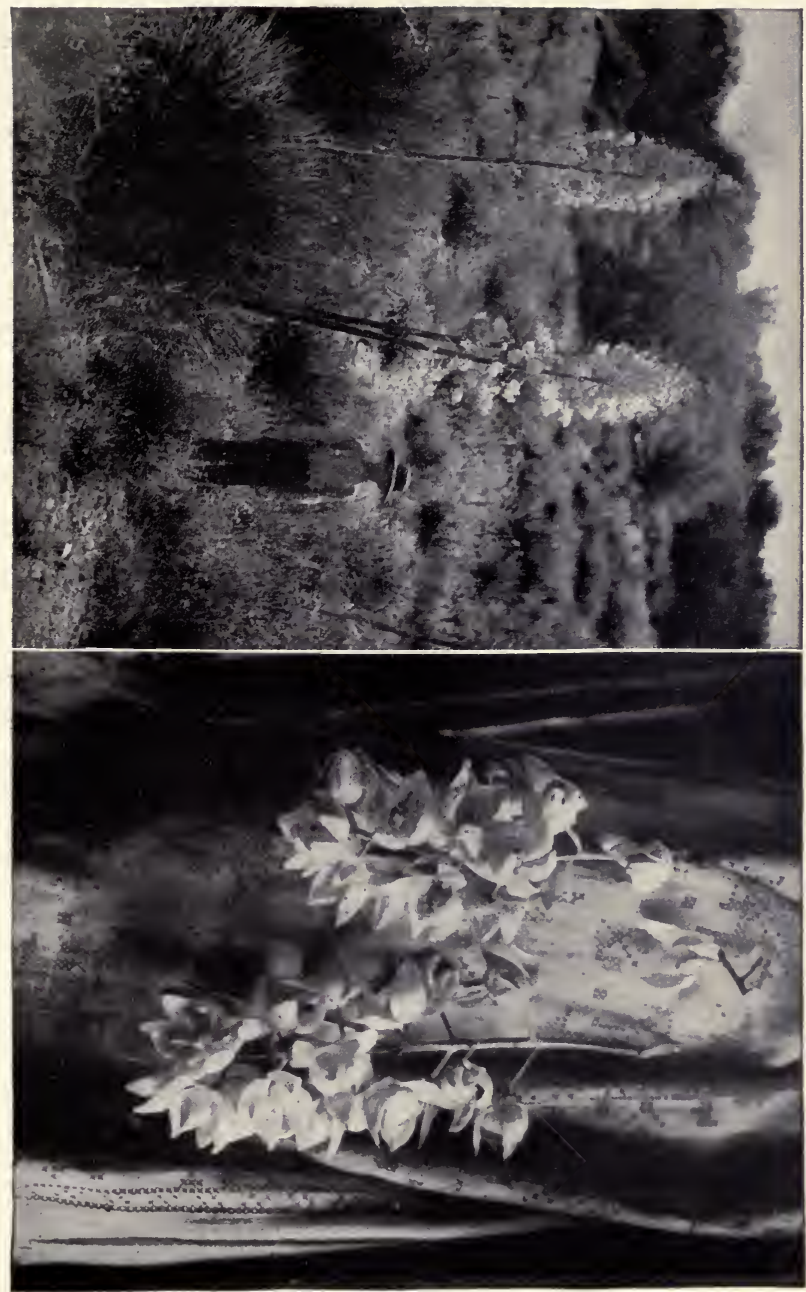



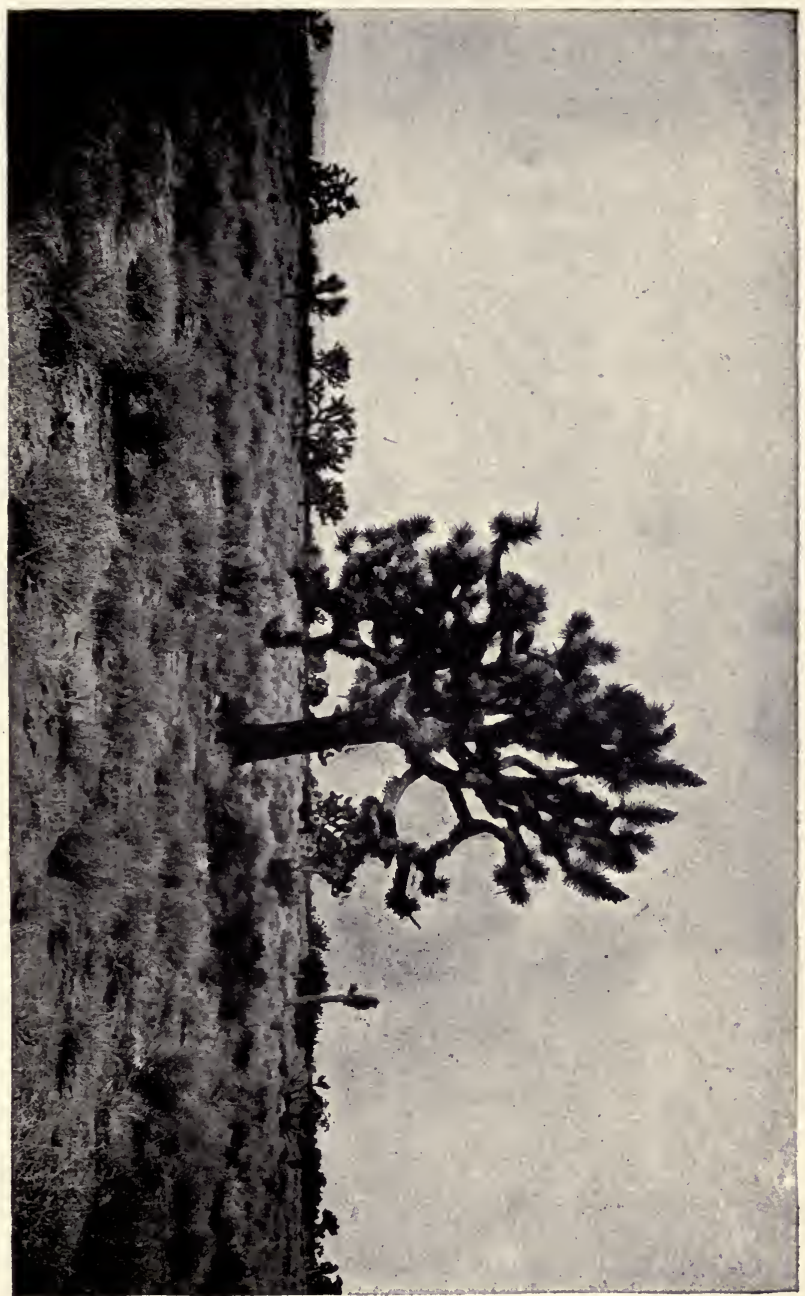




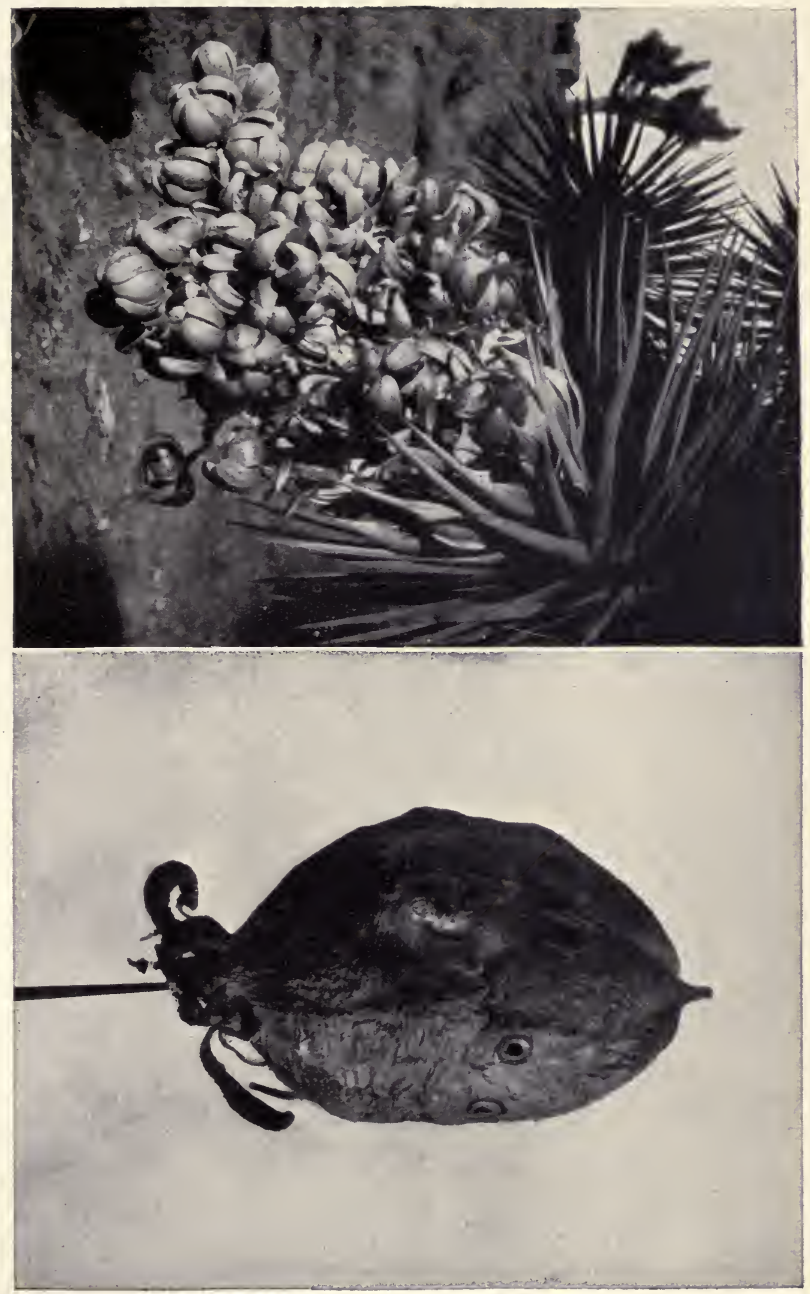


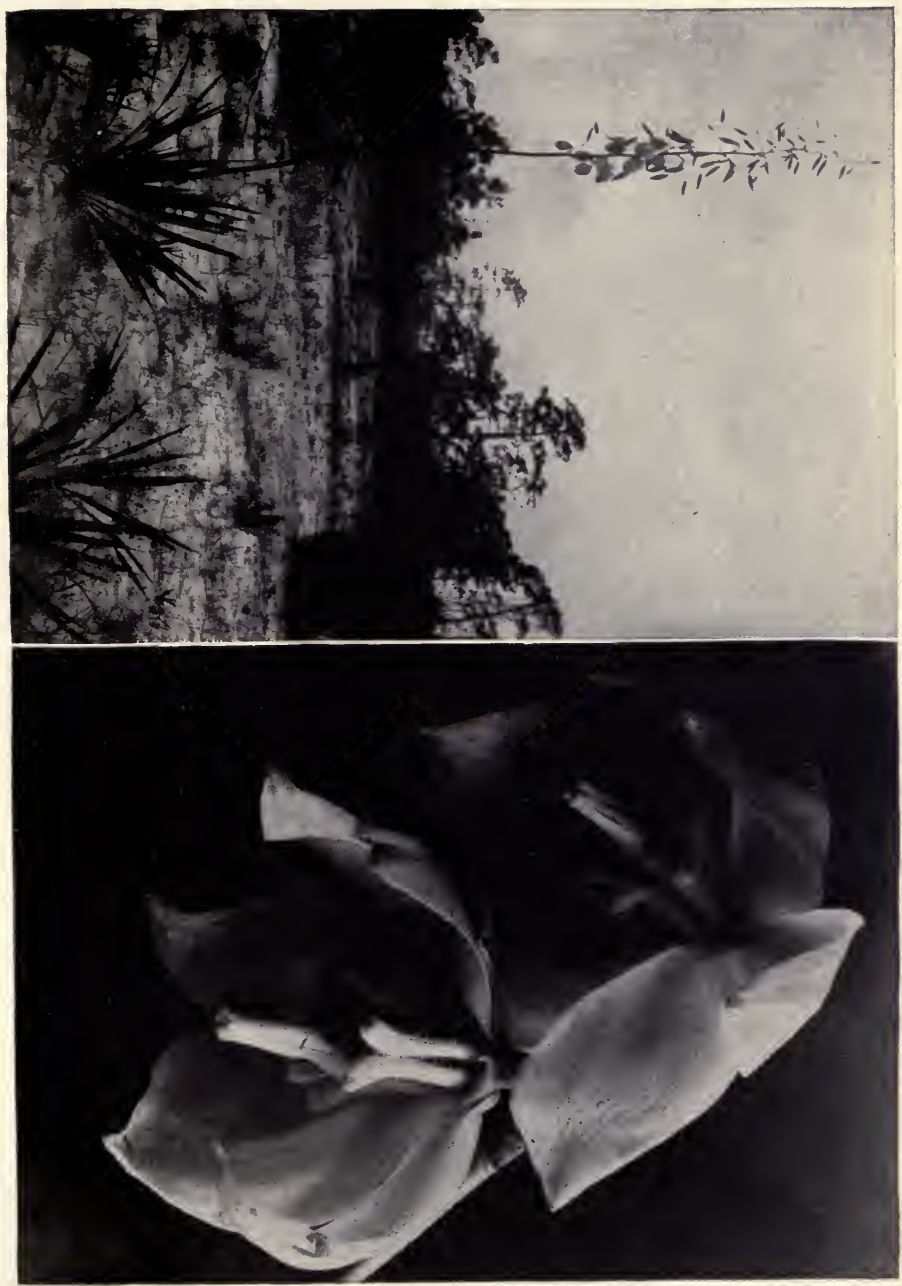



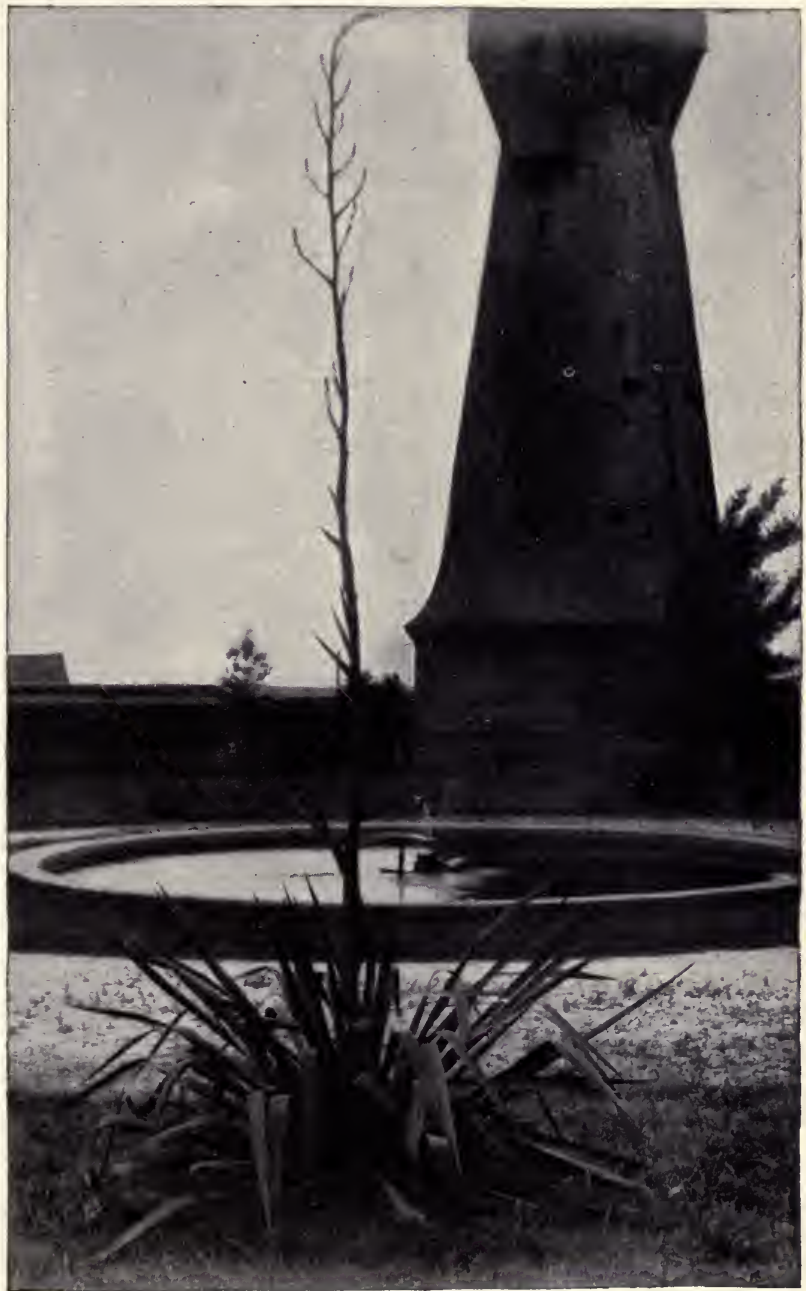





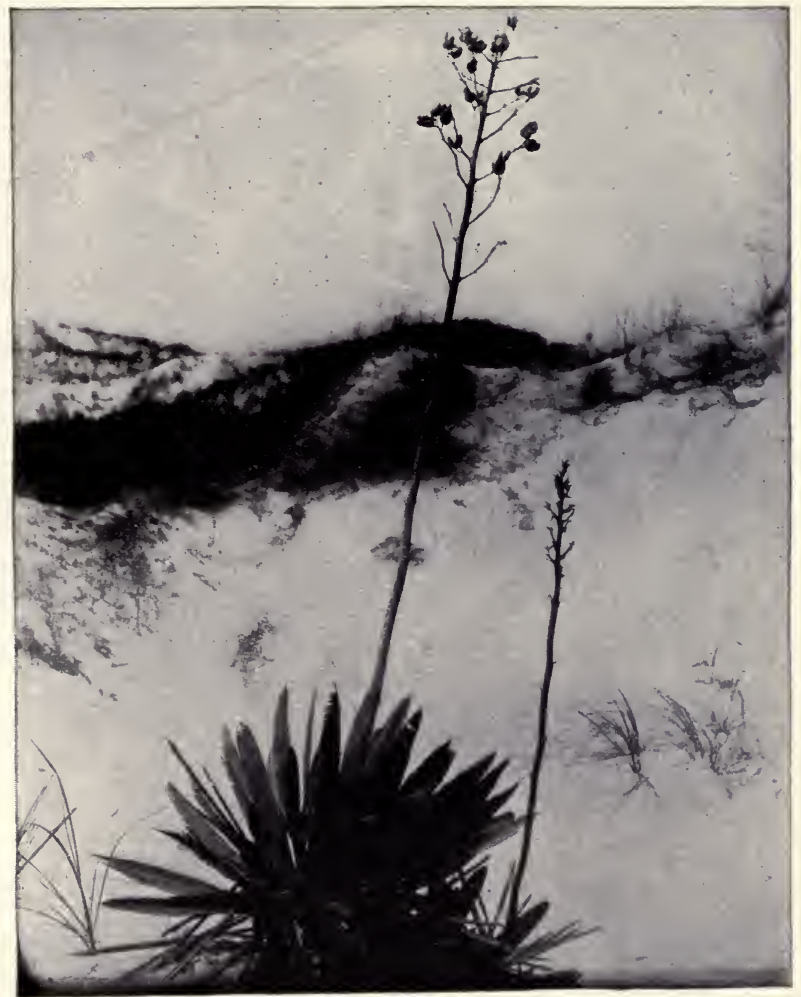





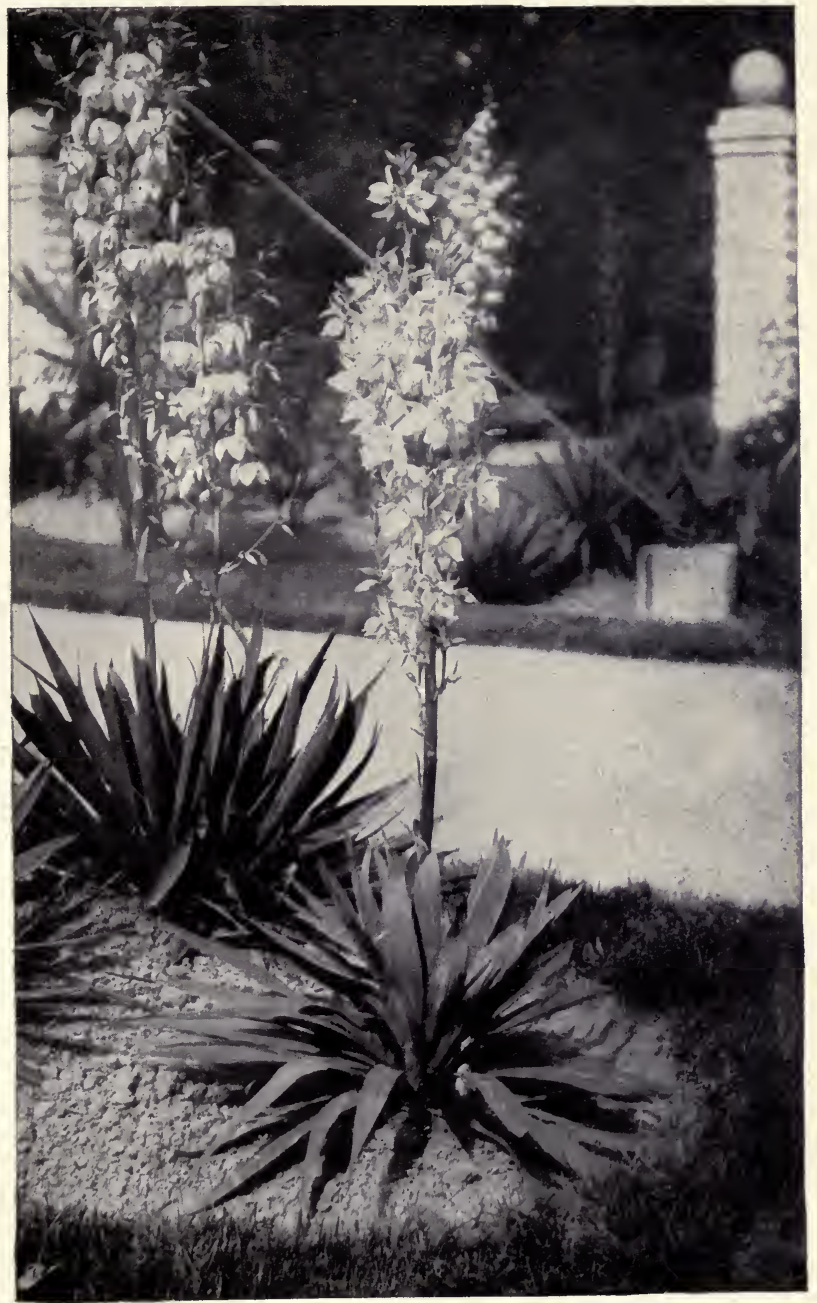





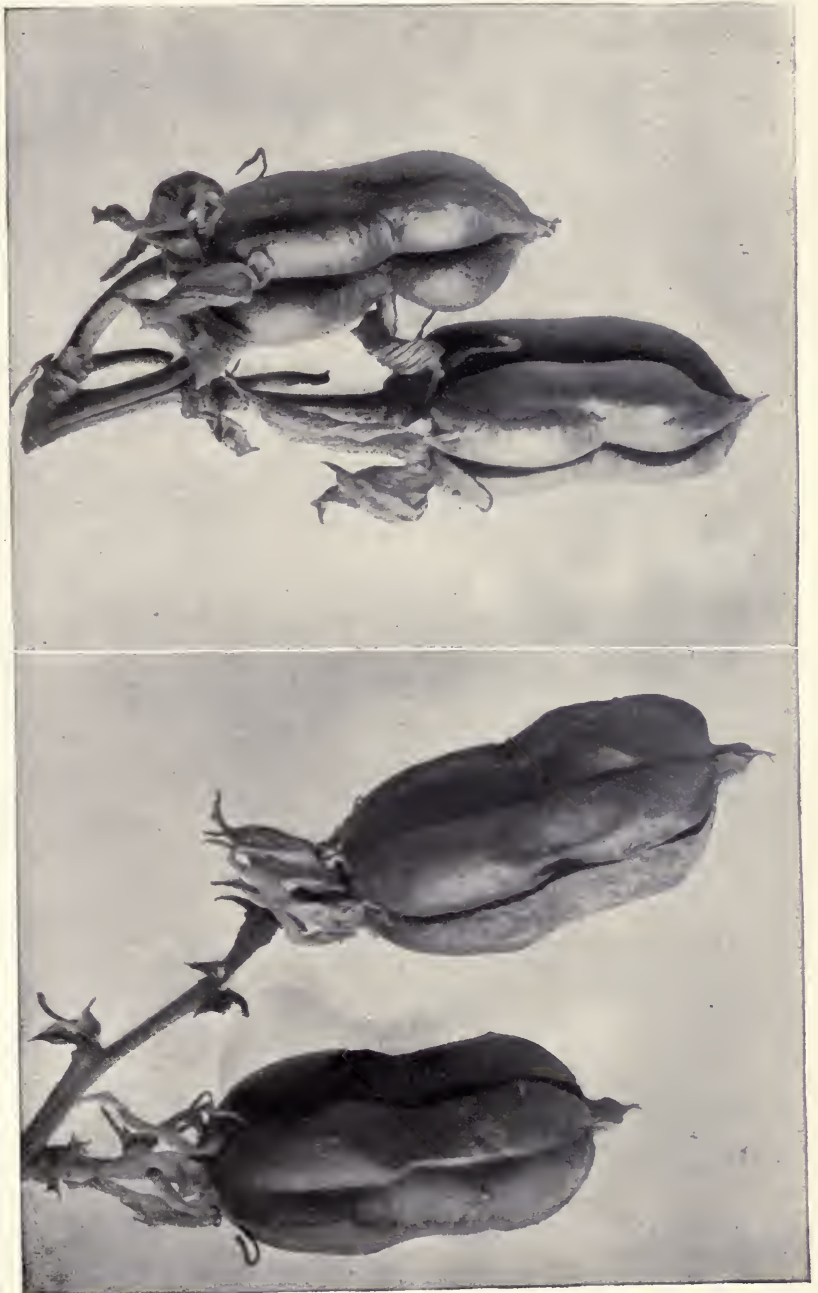

YUCCA FILAMENTOSA AND Y. FLACCIDA. 



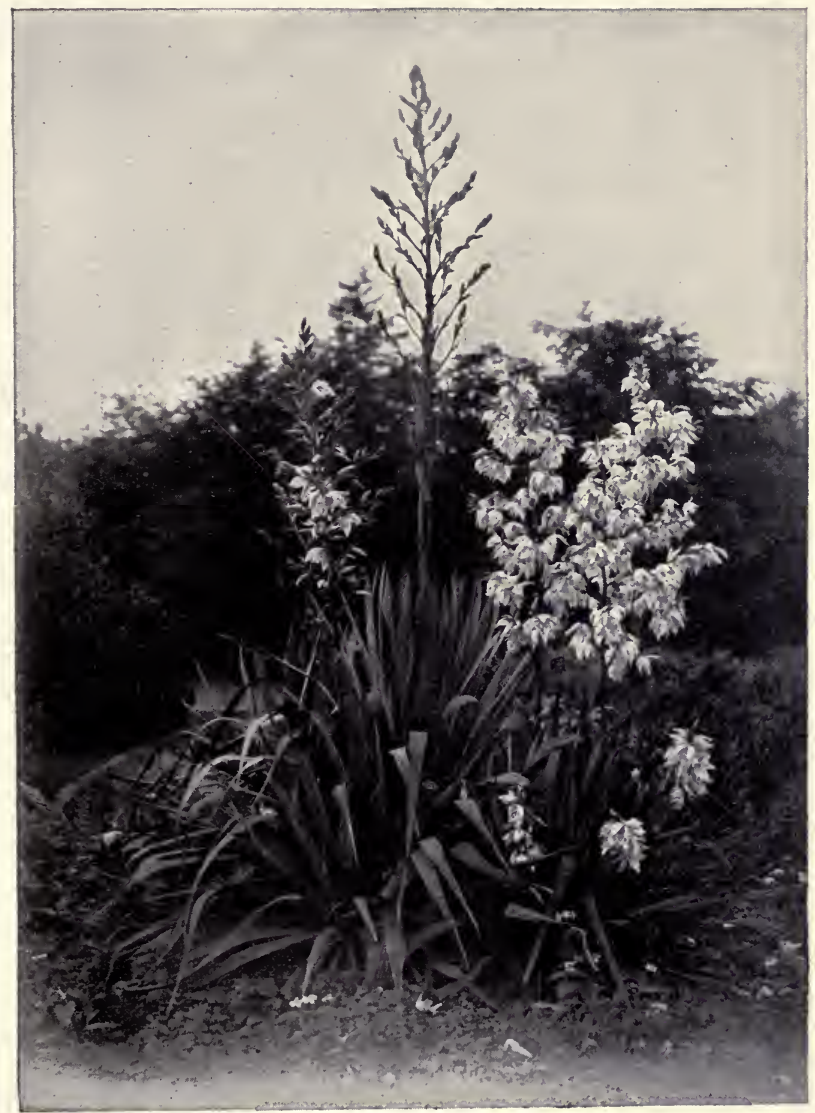





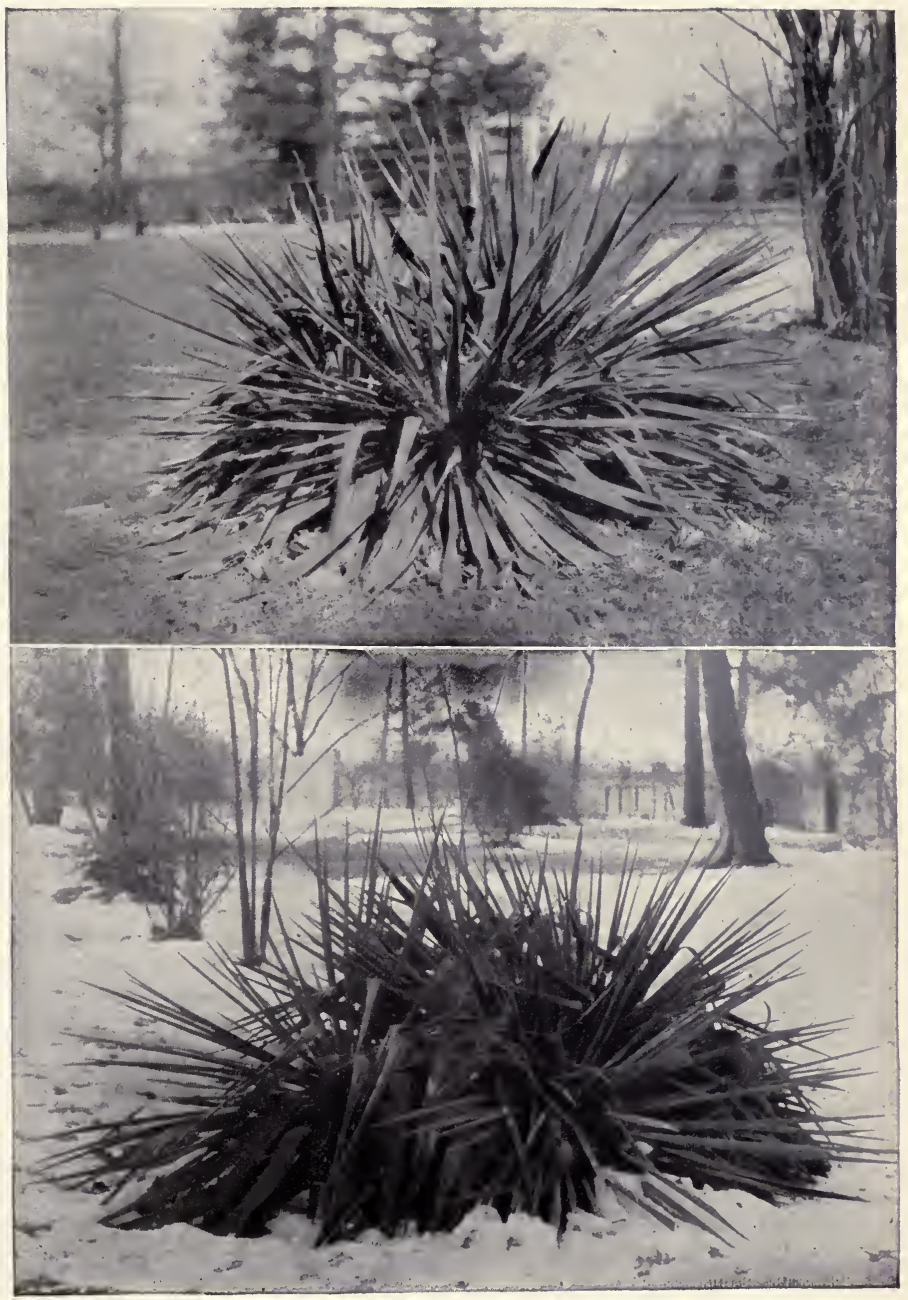





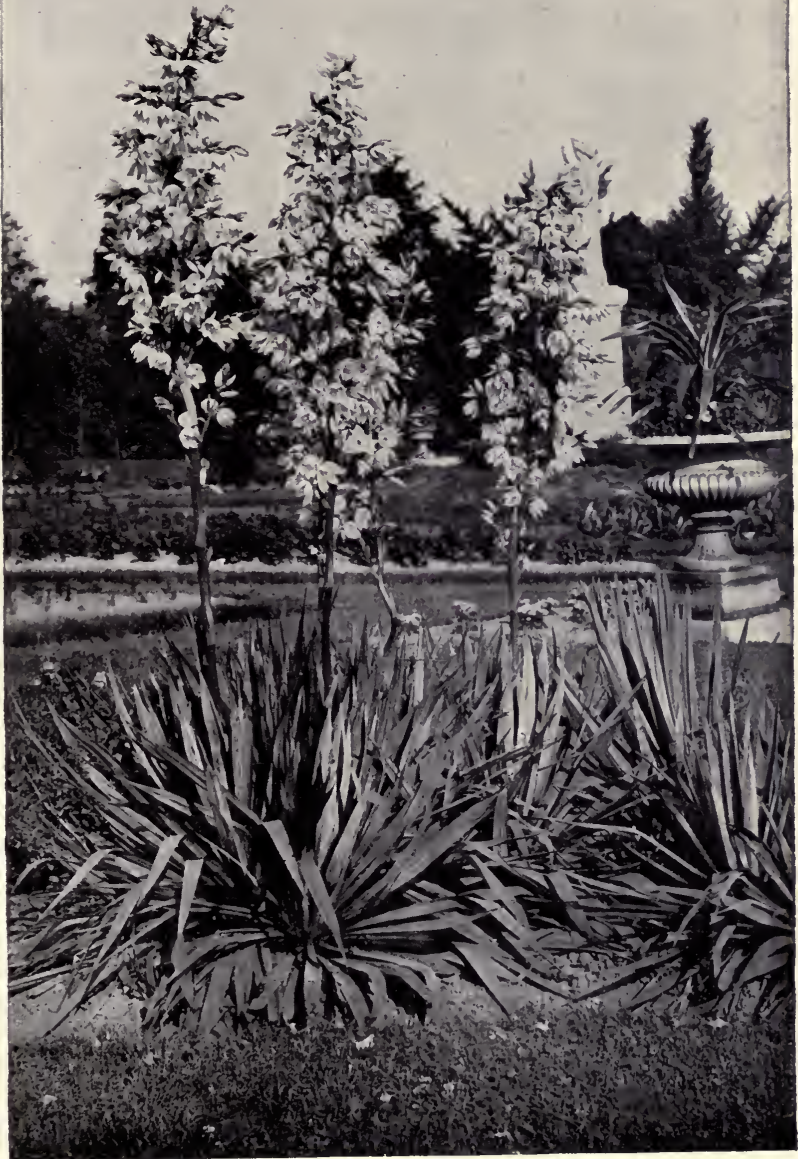





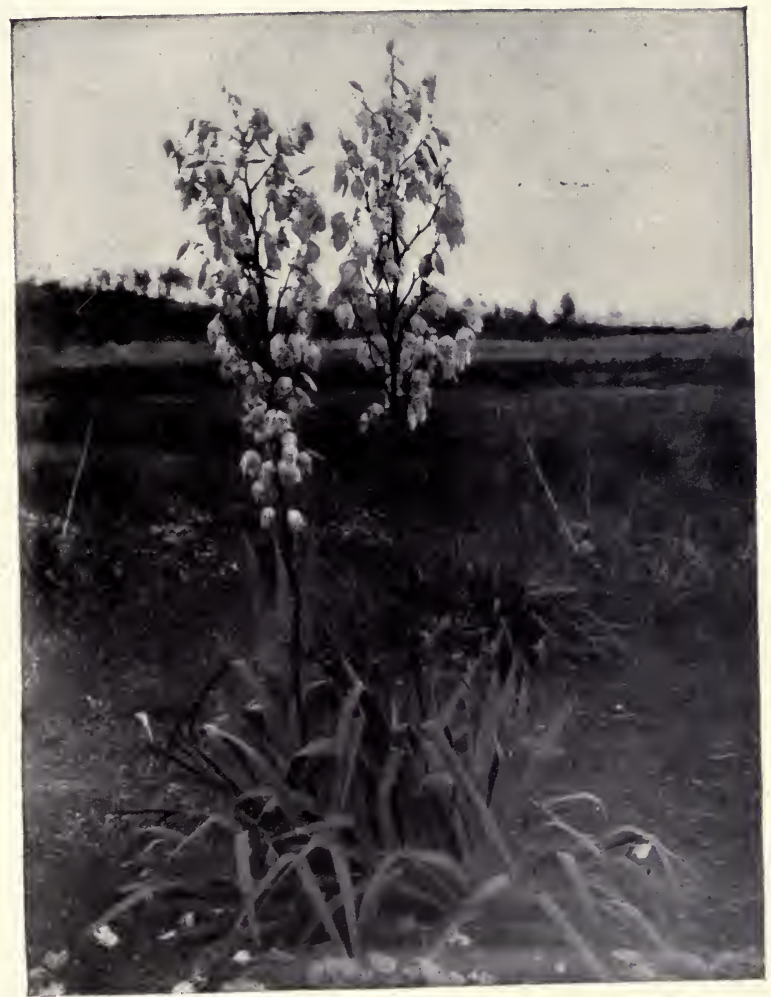





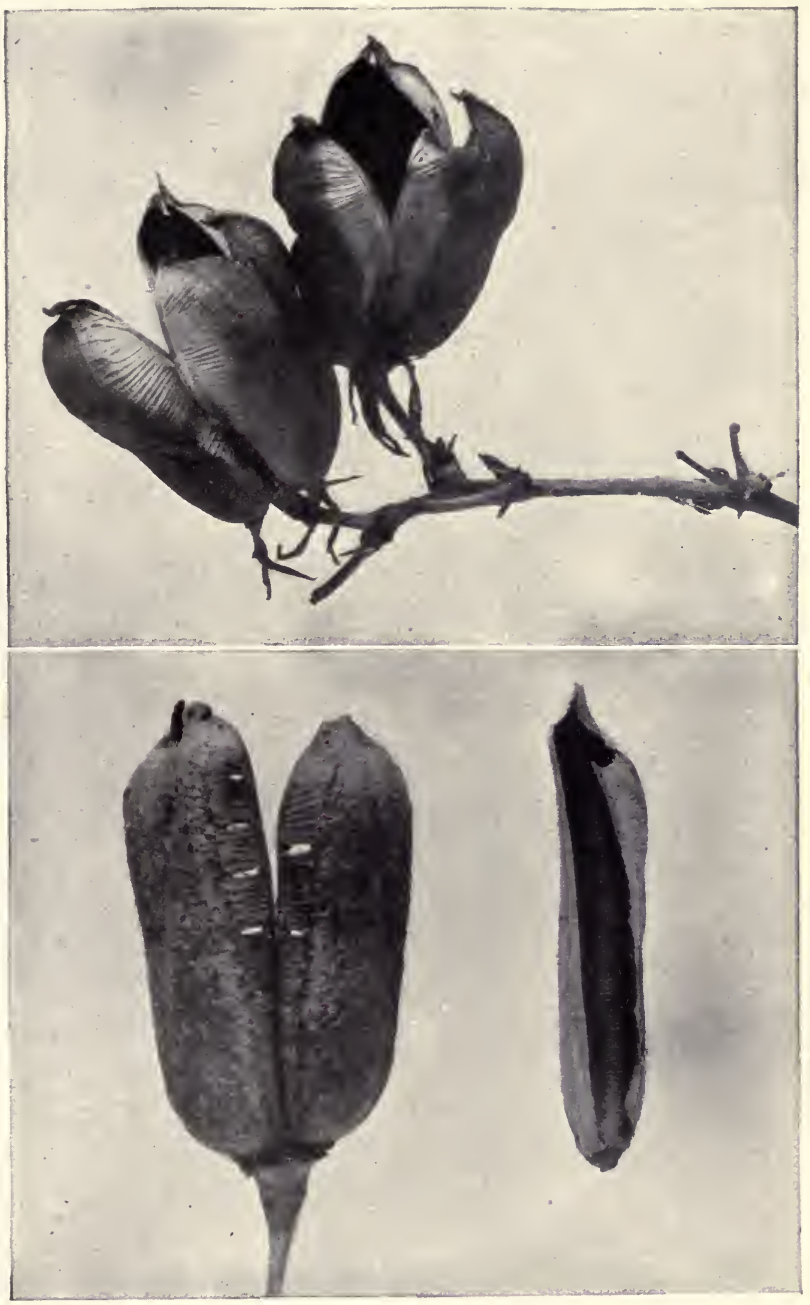





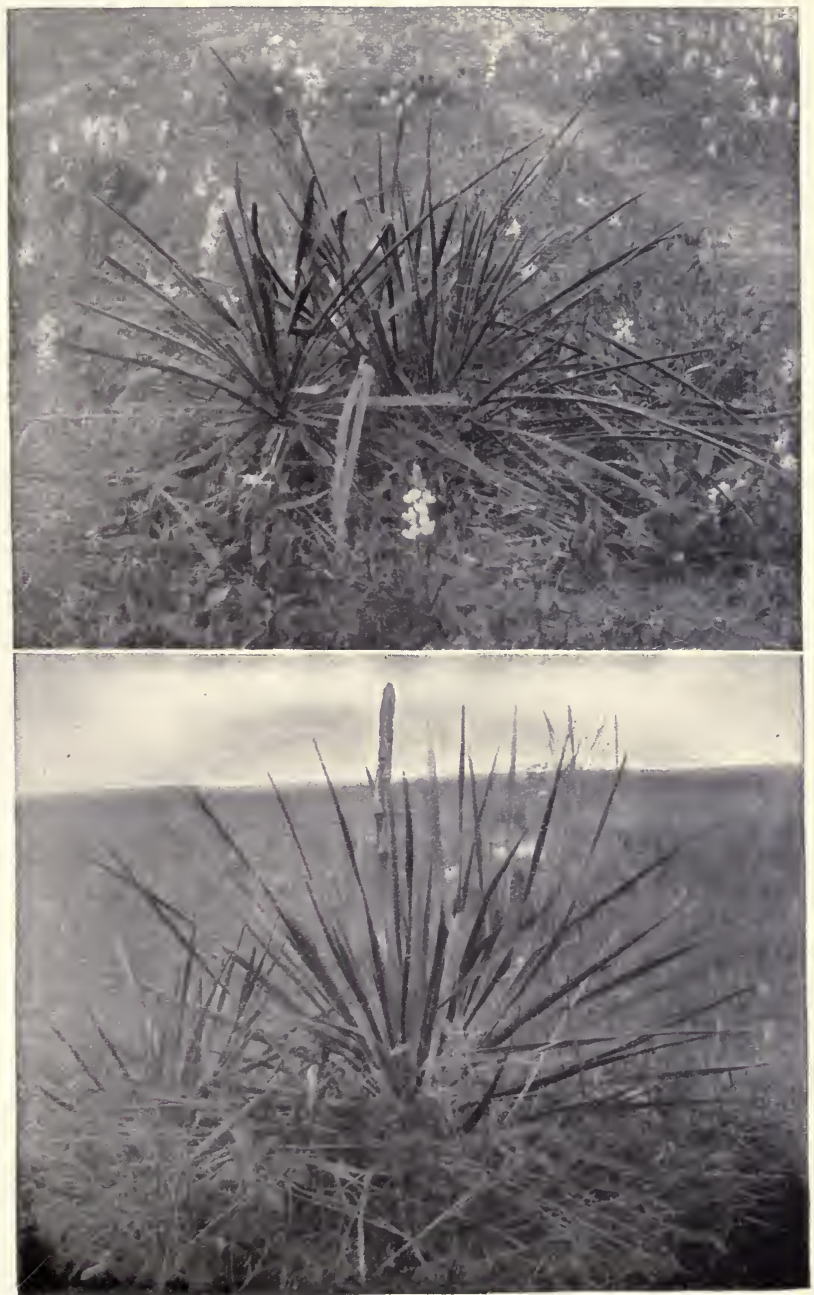





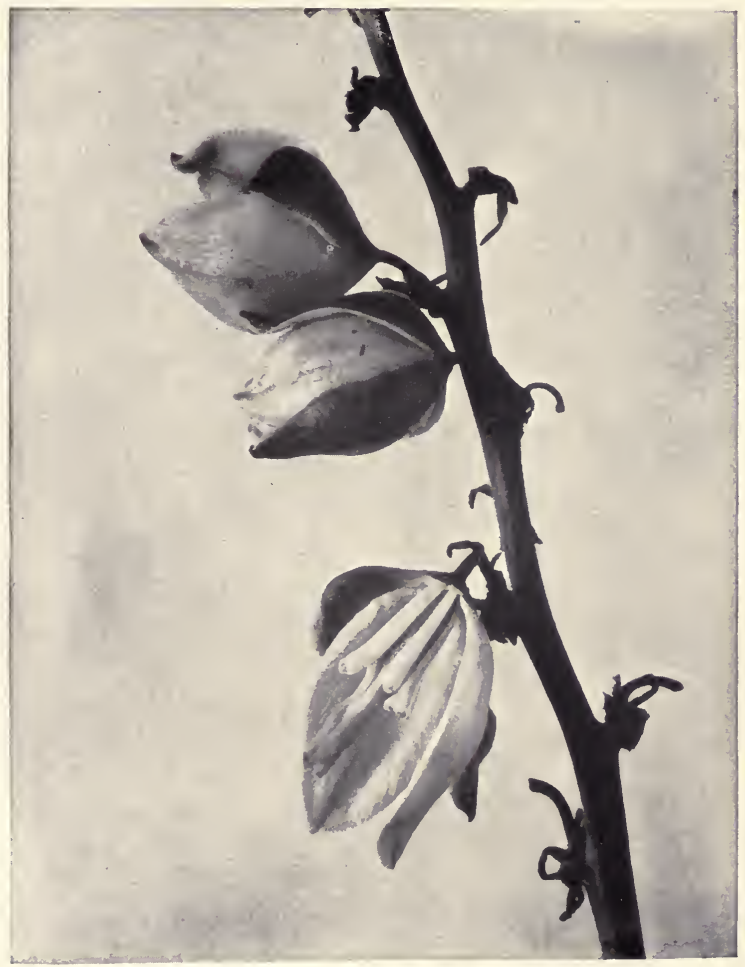




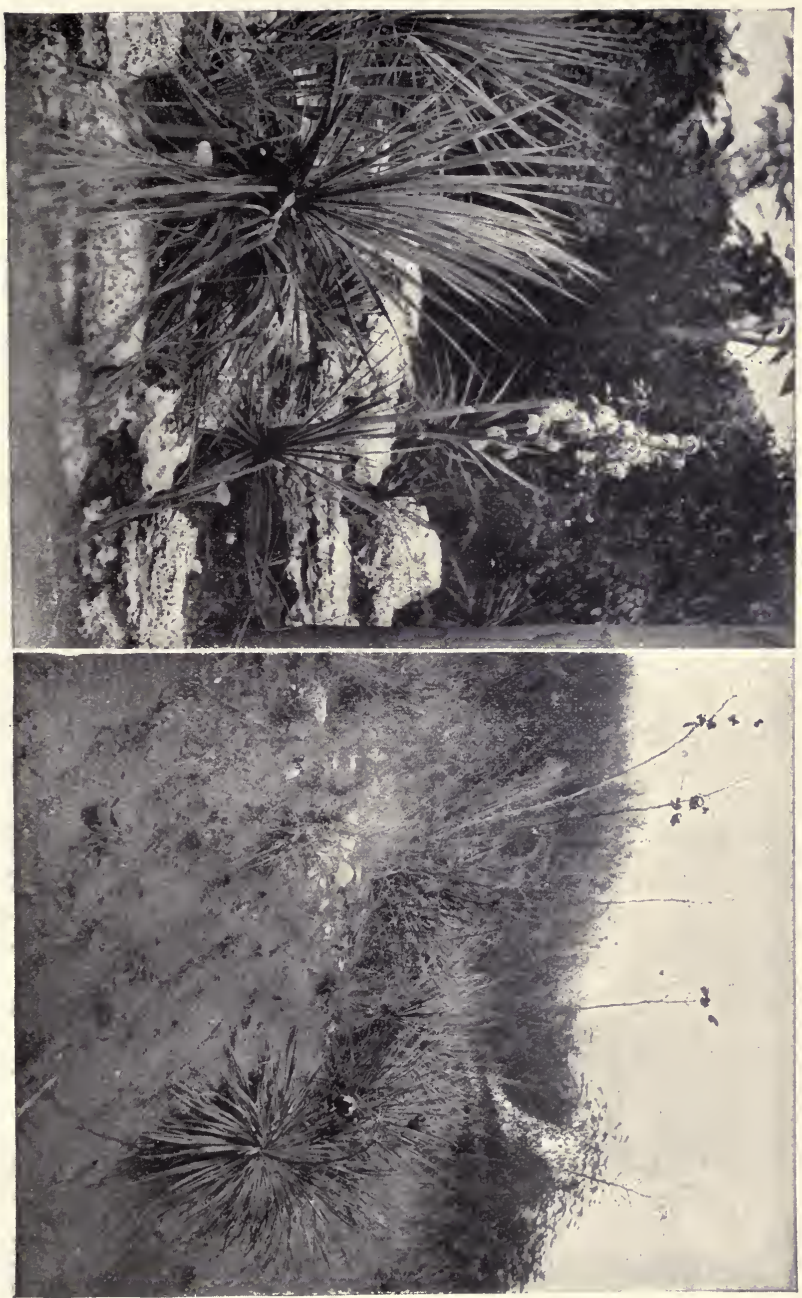



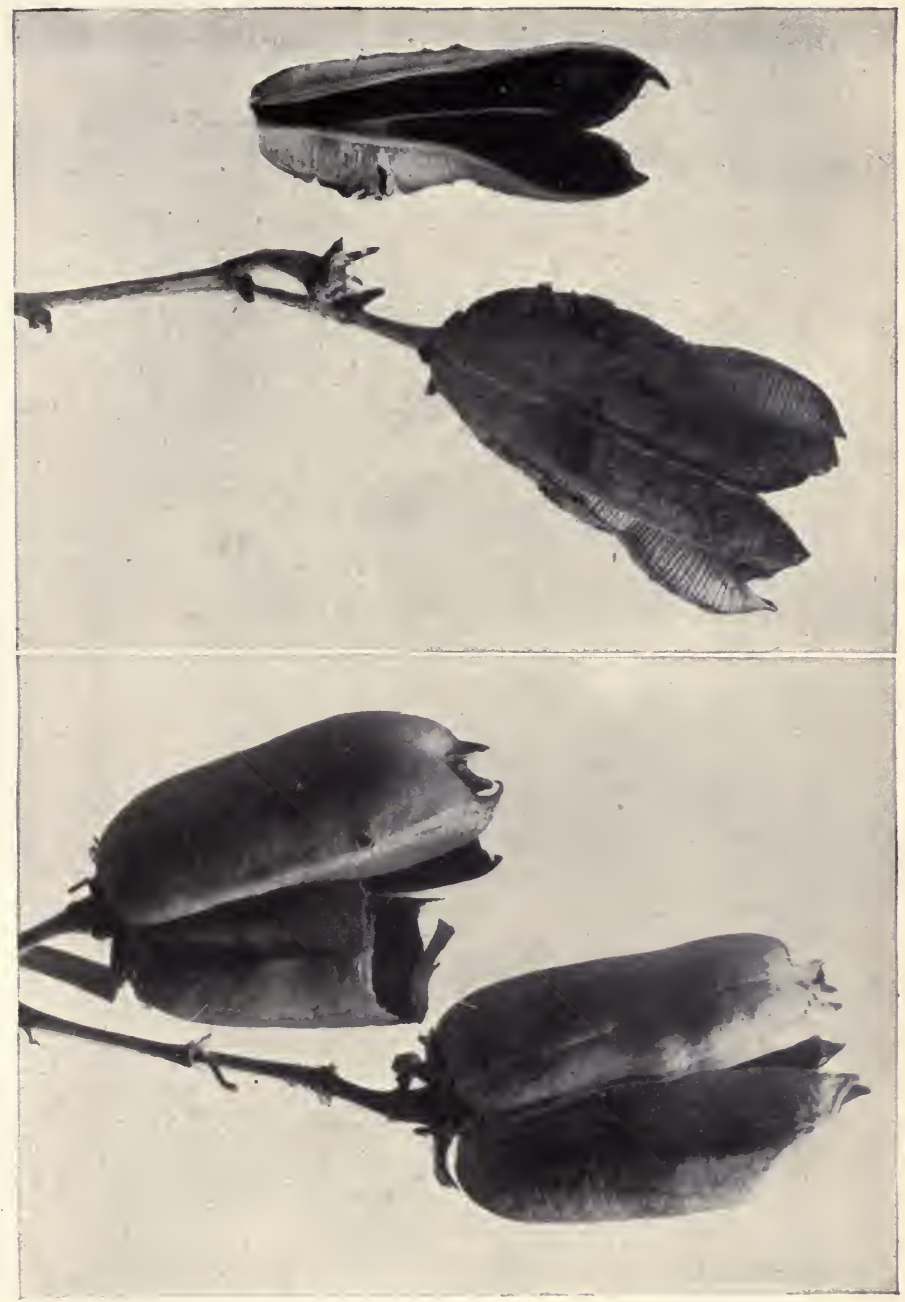





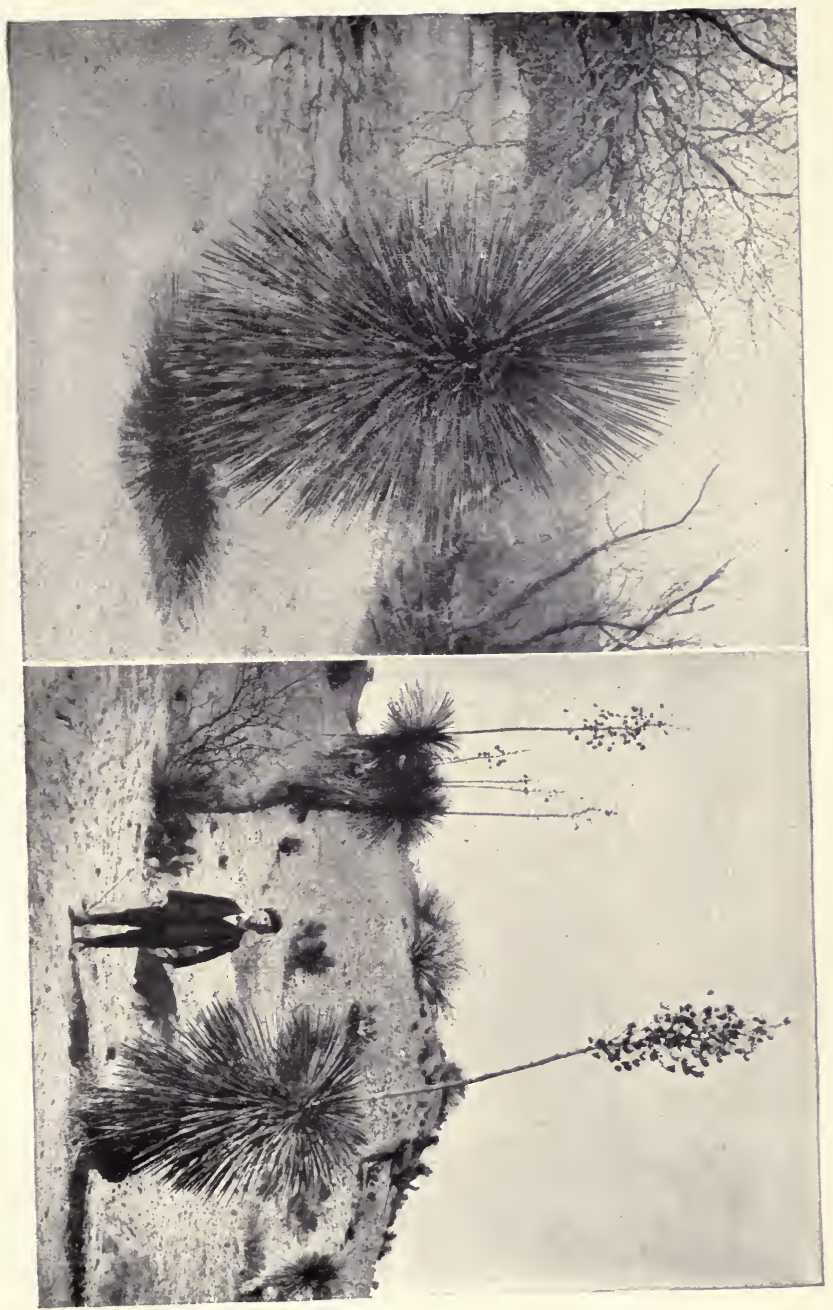





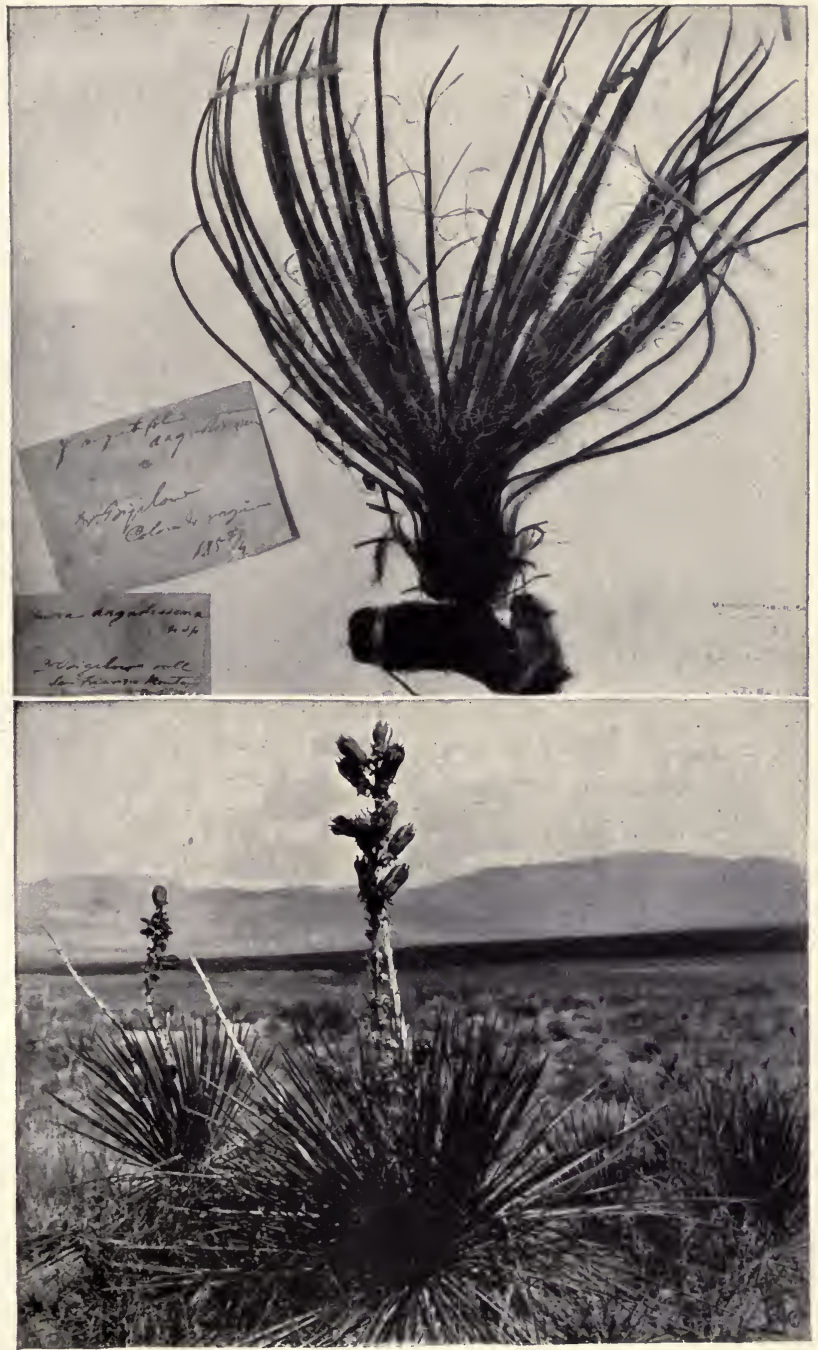

IUCCA ANGUSTISSIMA AND Y. GEAUCA. 



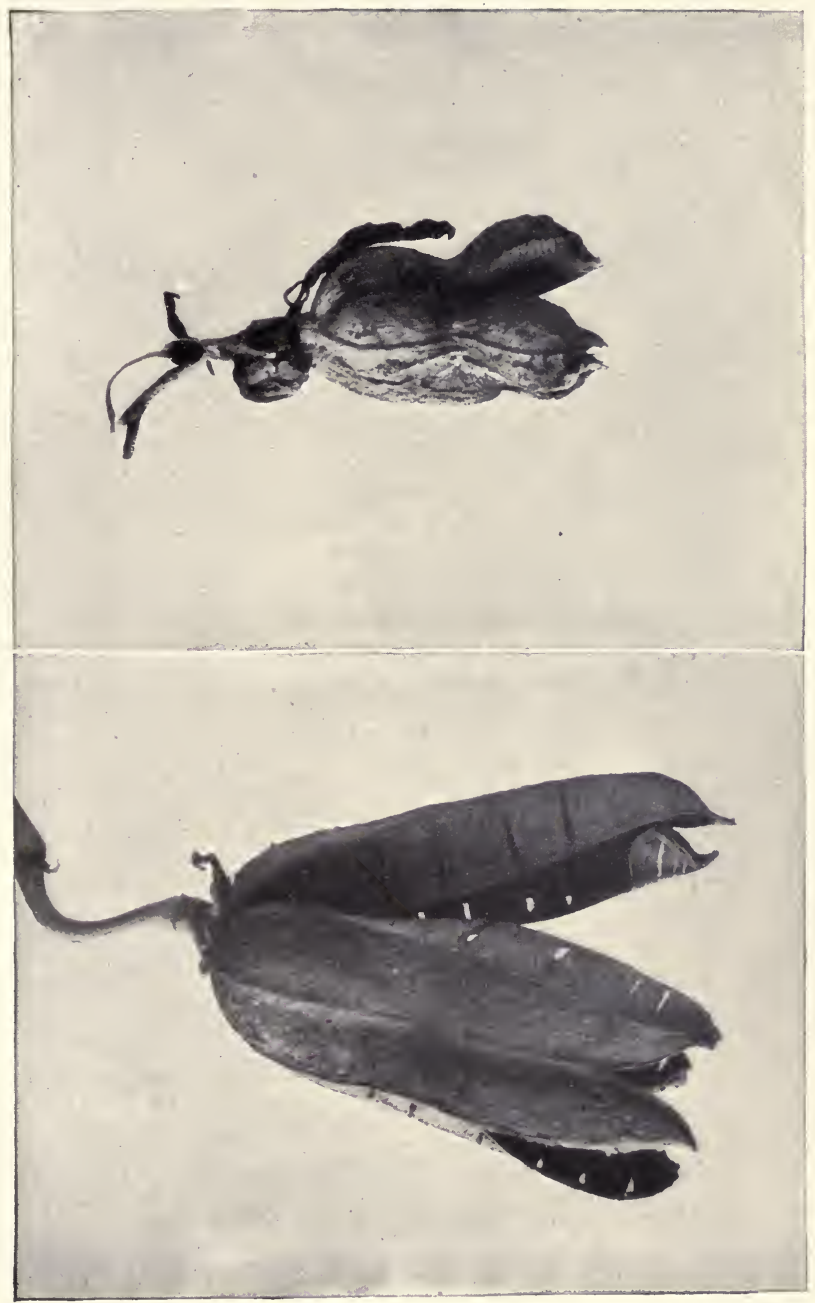

YUCCA ANGUSTISSIMA AND Y. GLAUCA. 



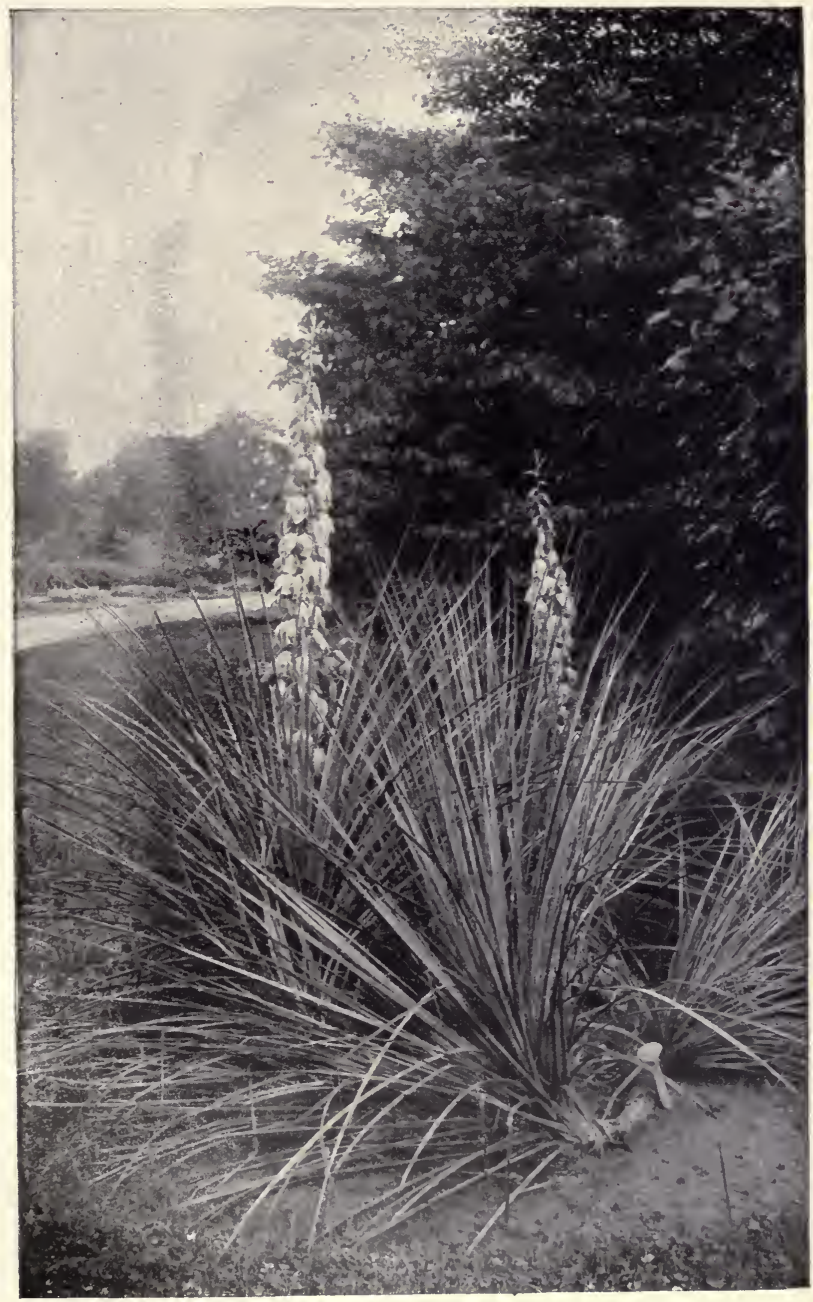





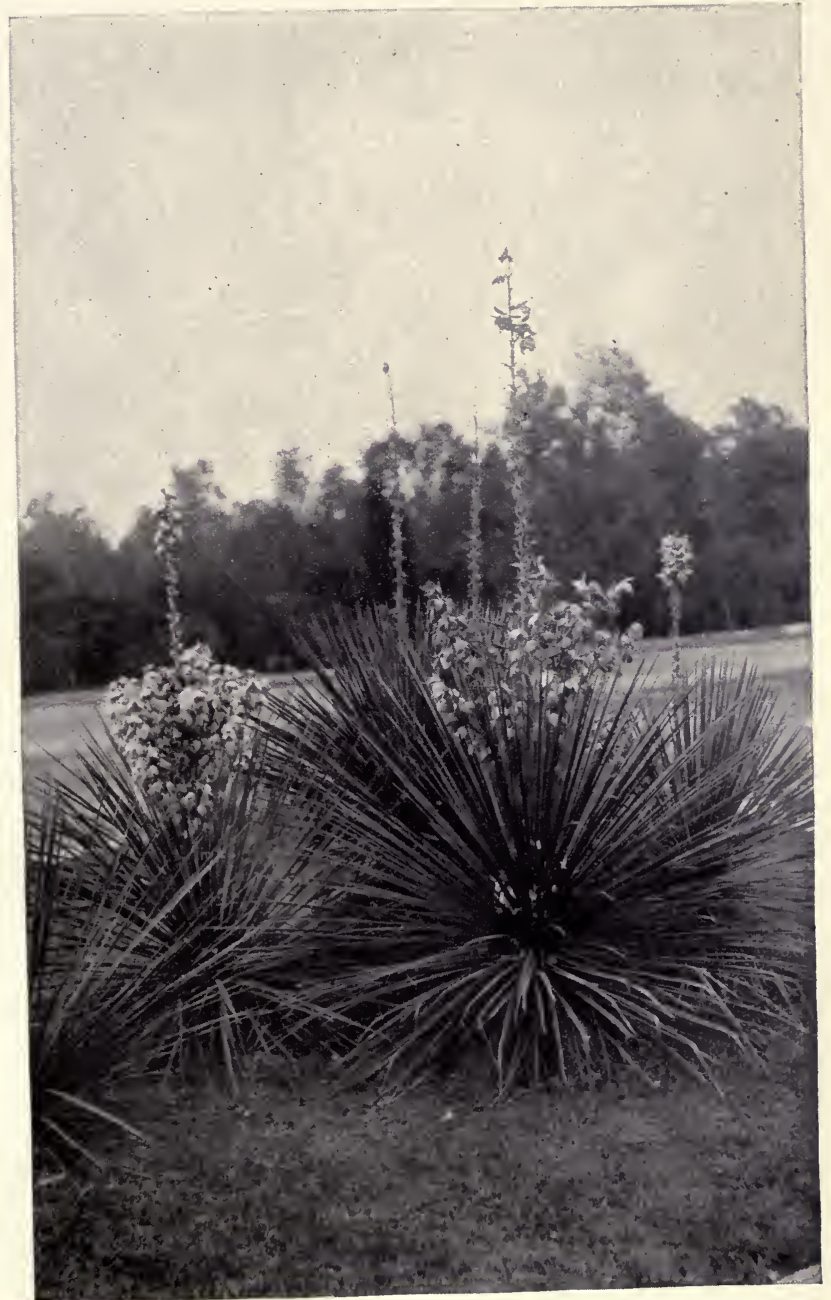





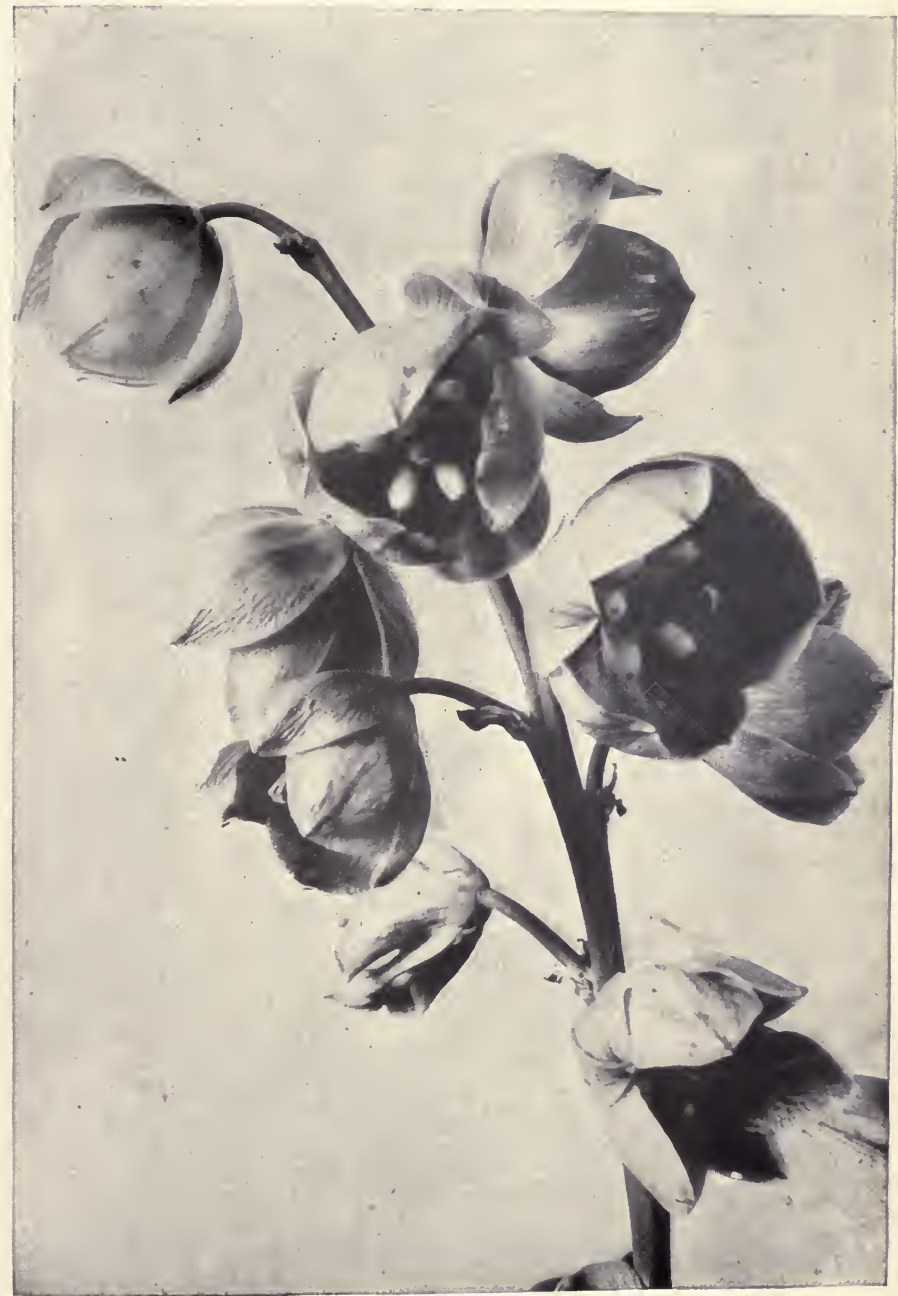





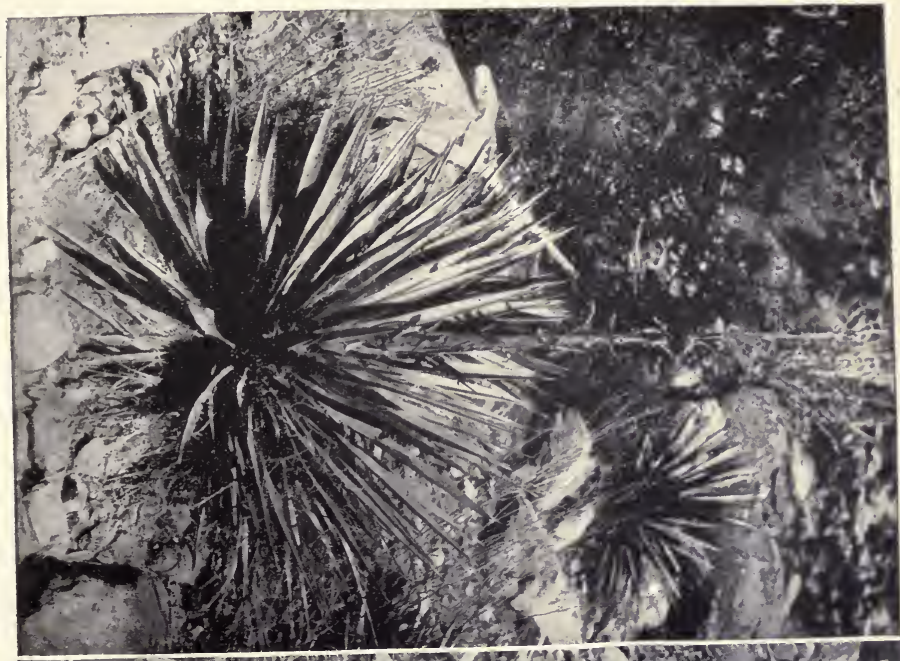

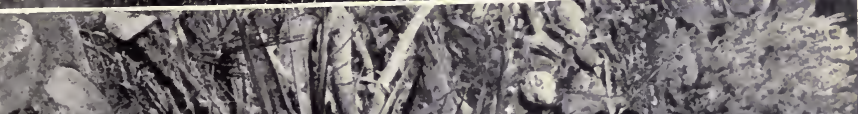

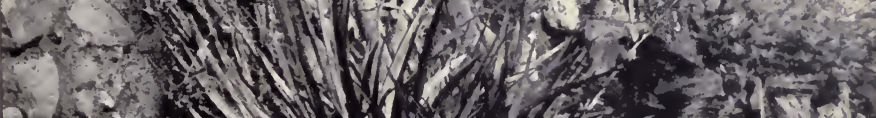

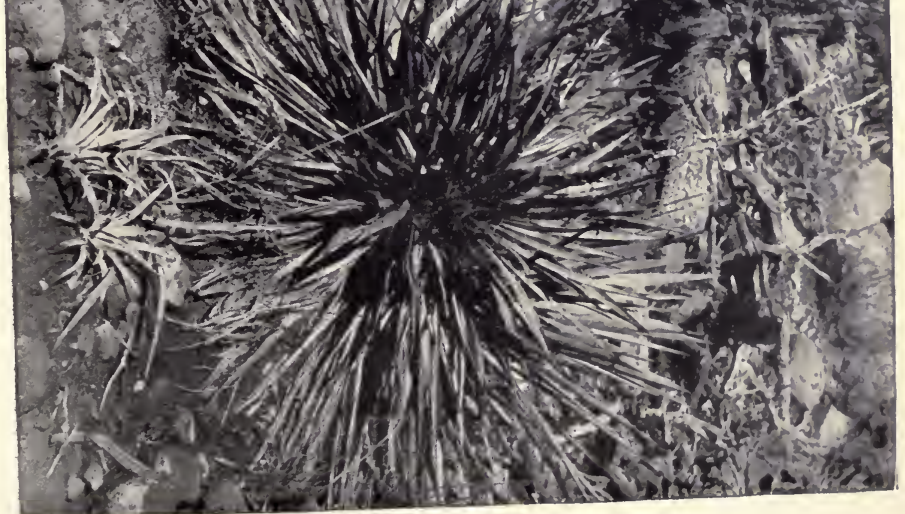


$$
\text { - }
$$ 


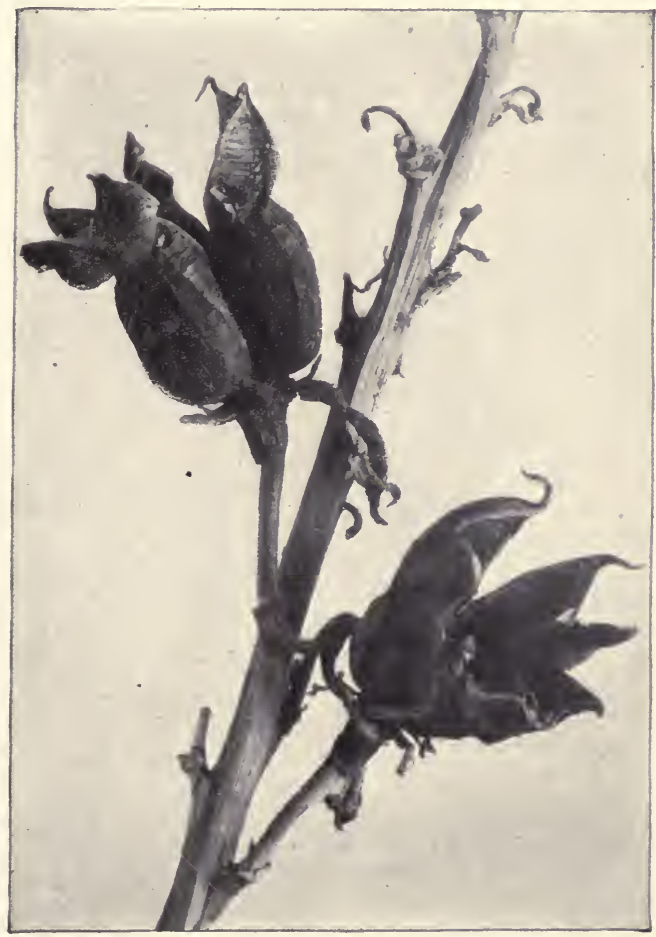





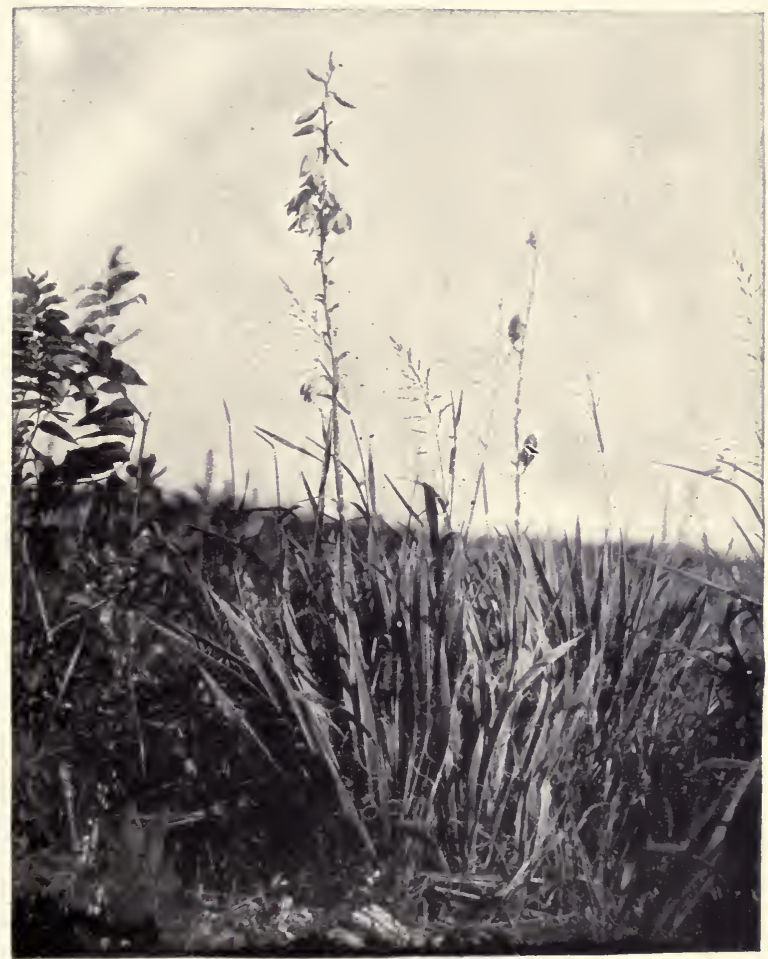





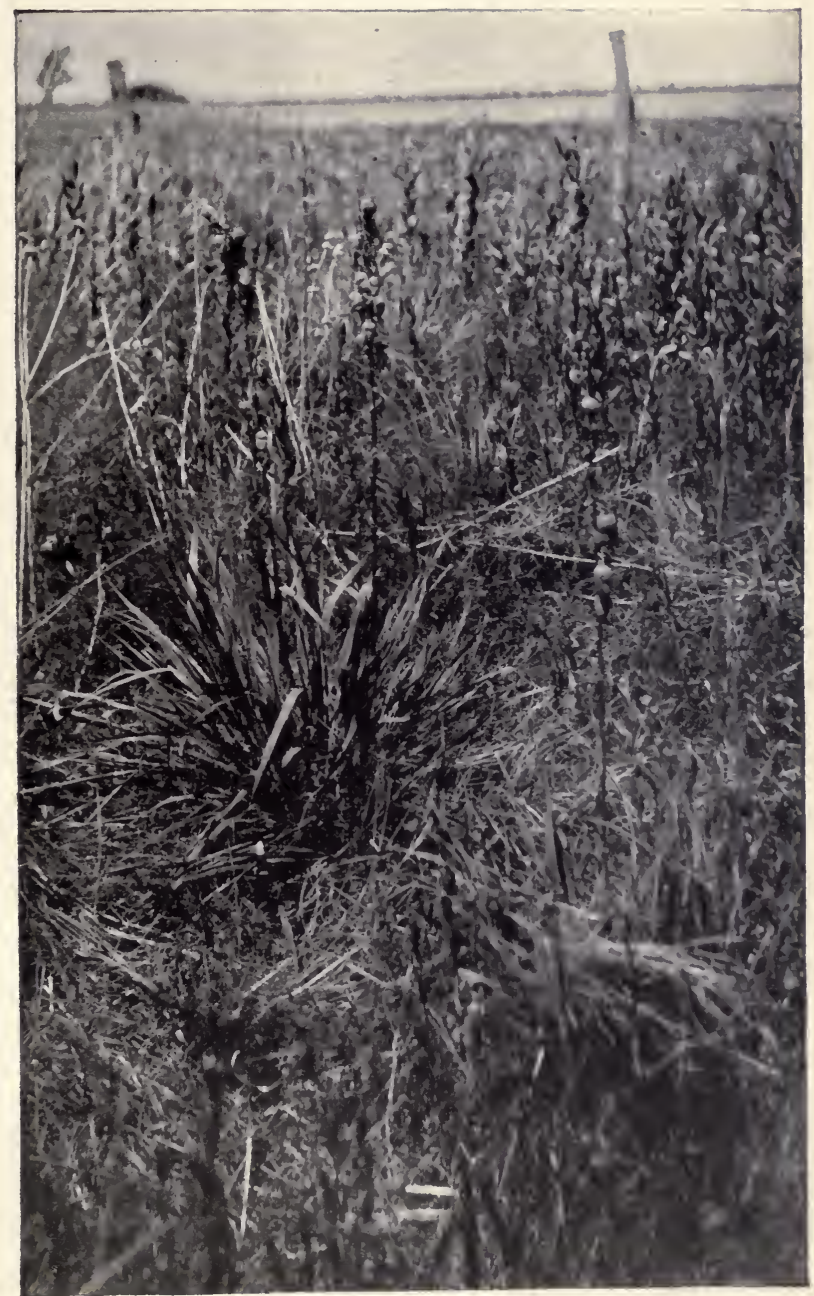






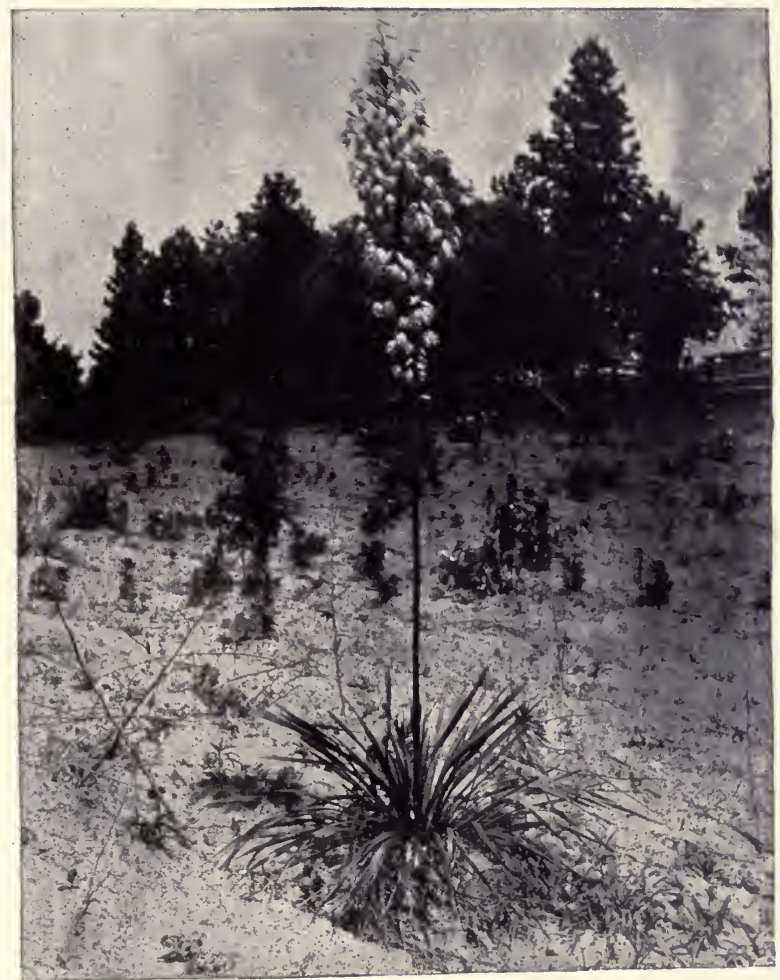




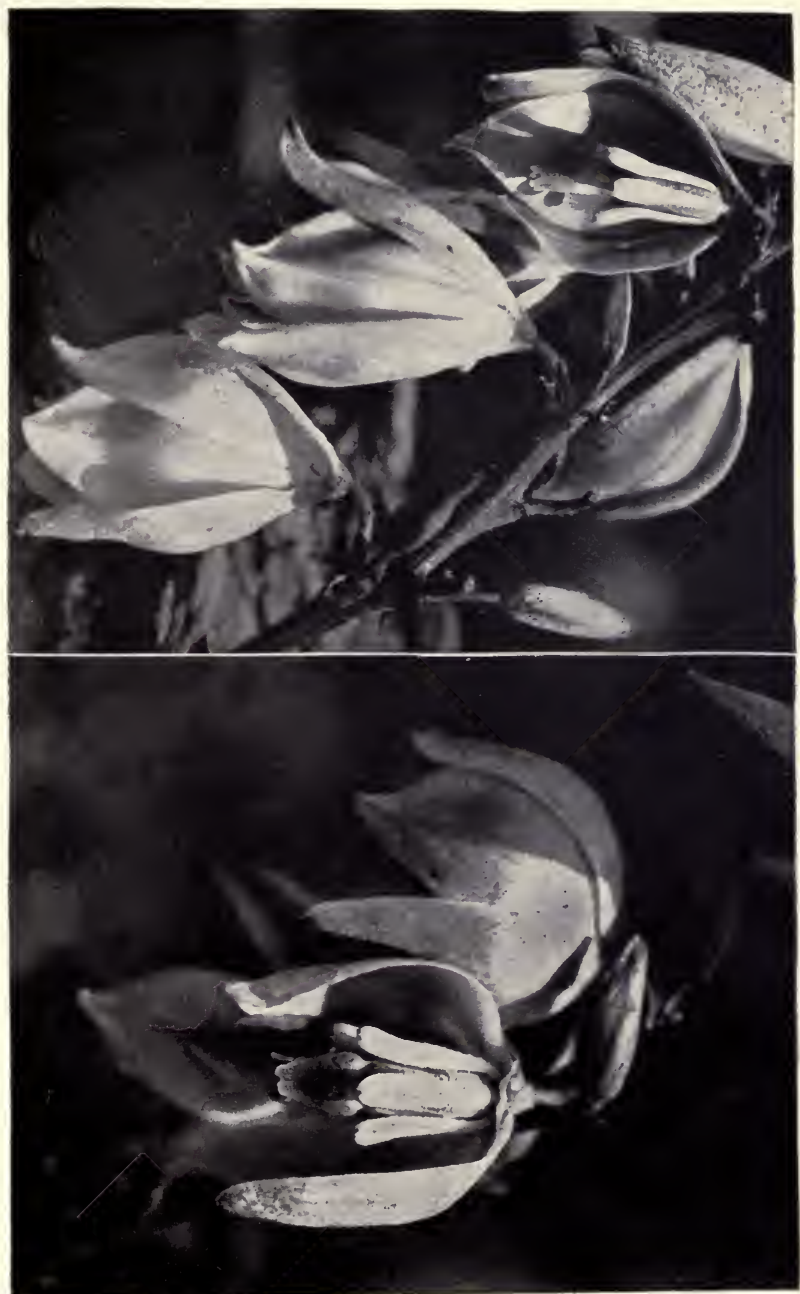

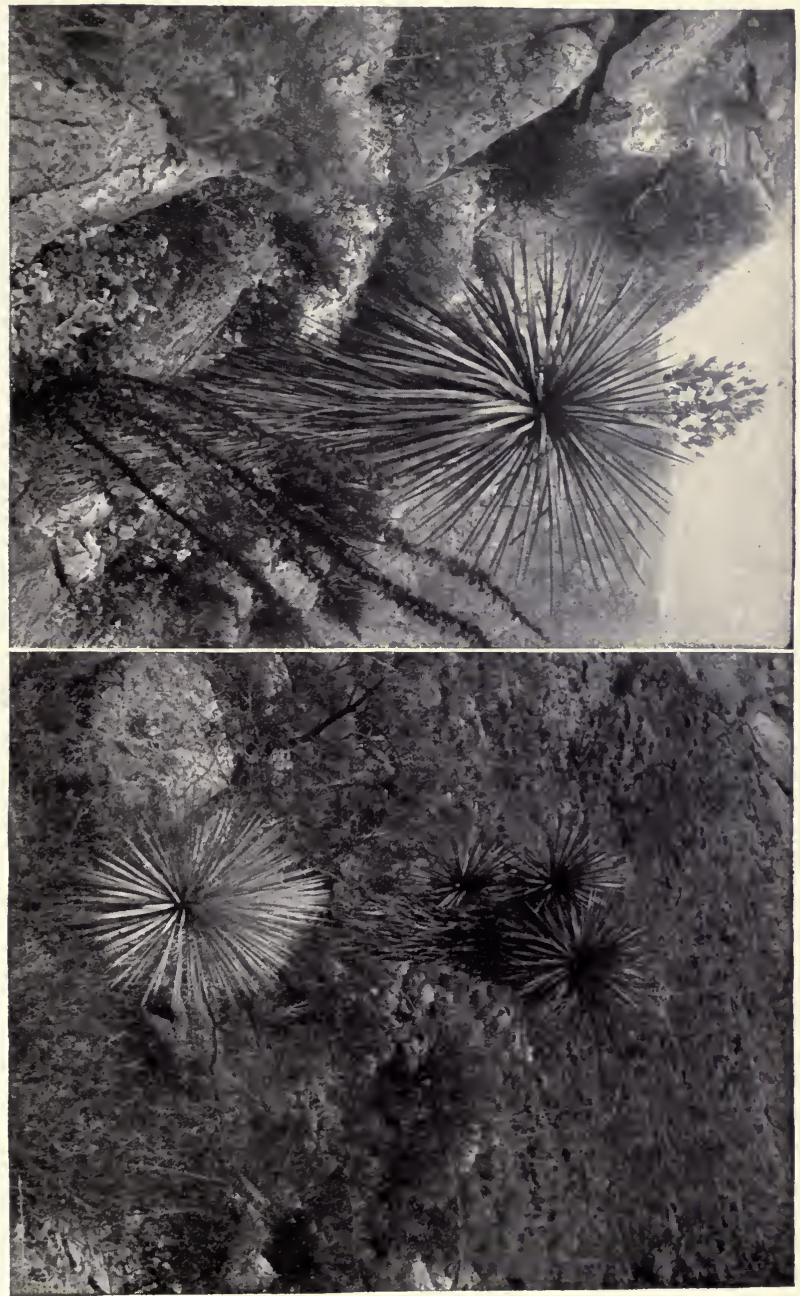


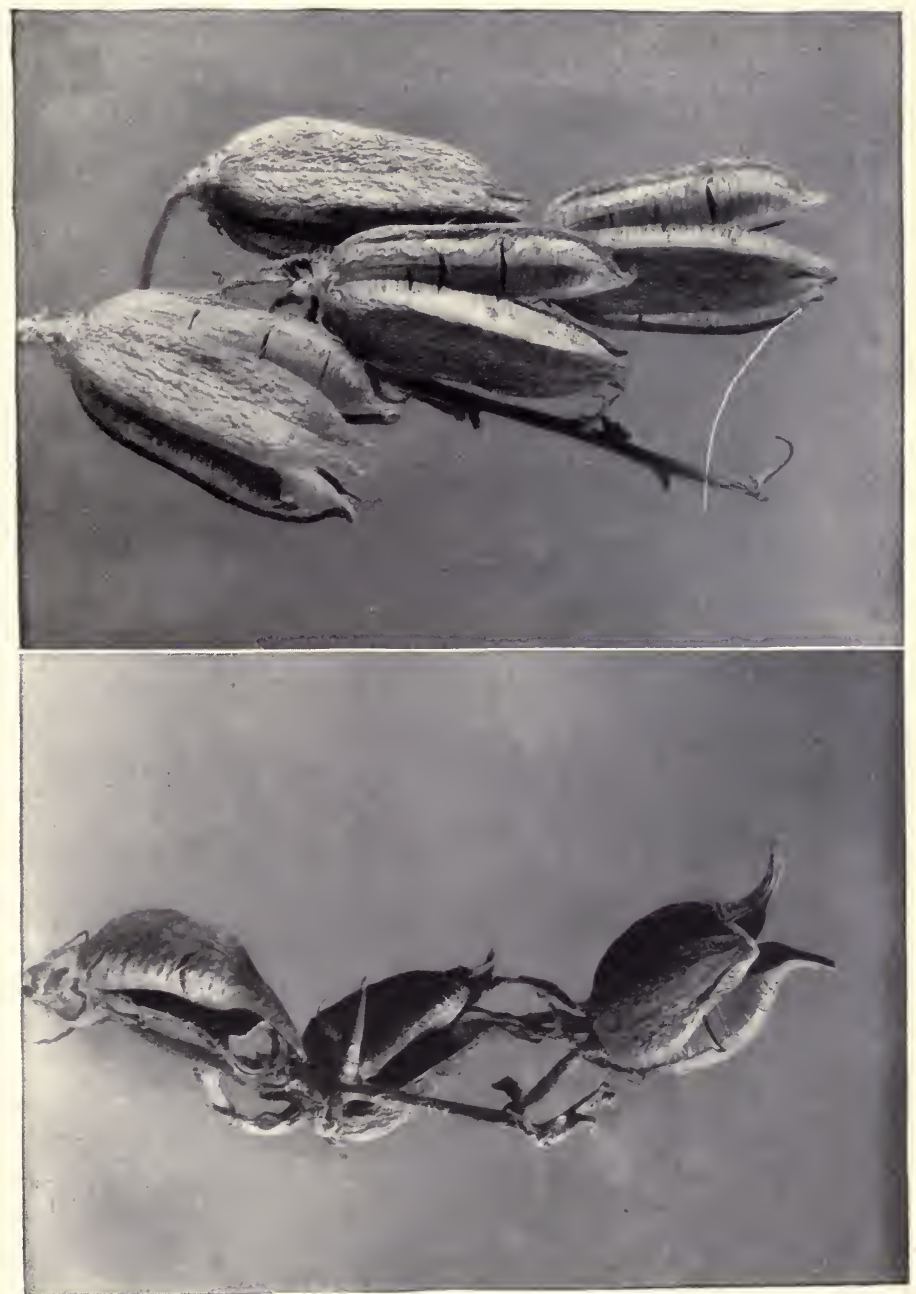



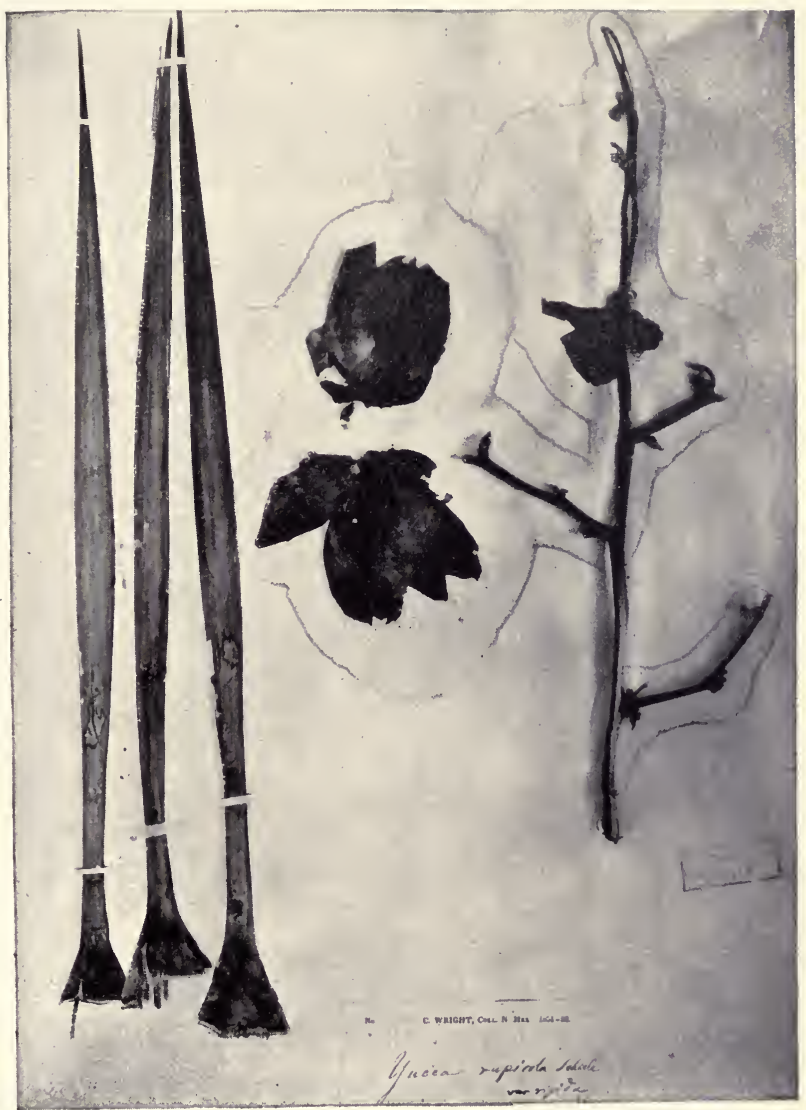





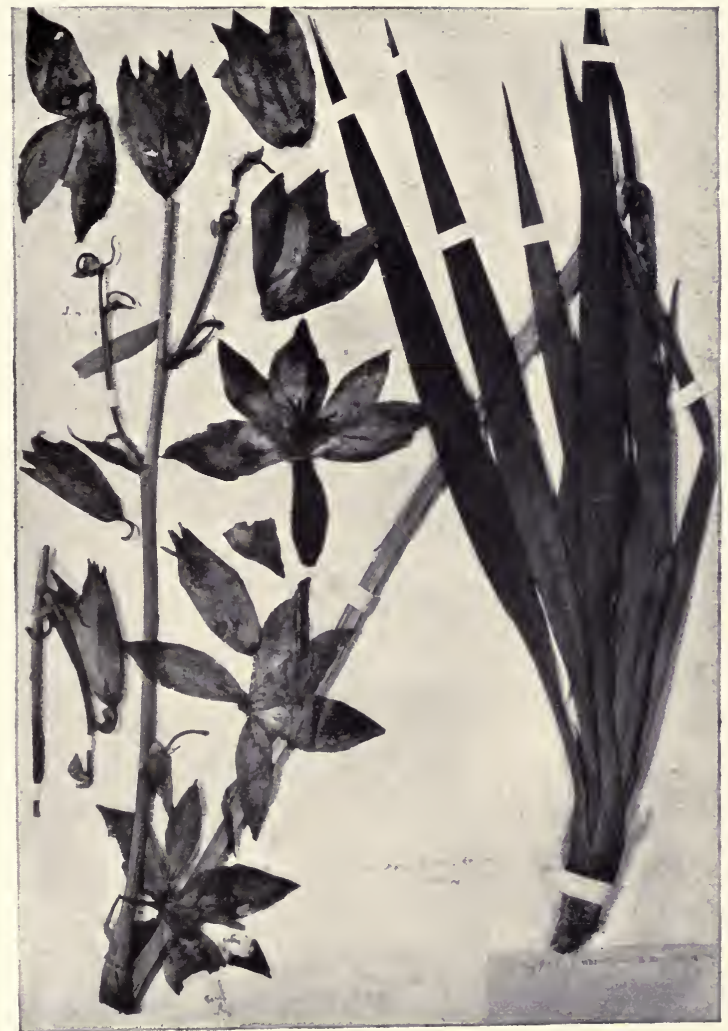




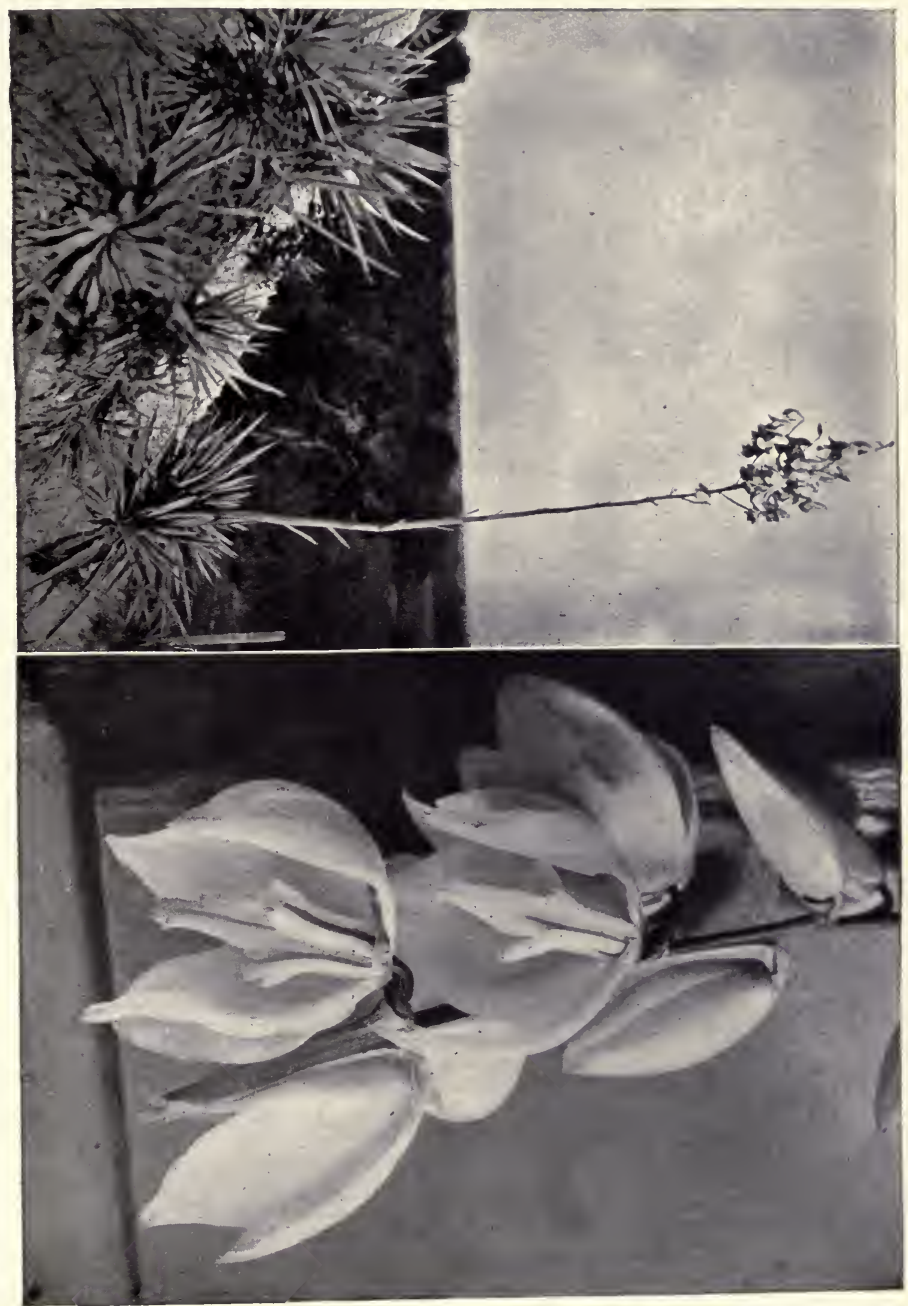

Rept. Mo. Bot. Gard., Vol. 13.

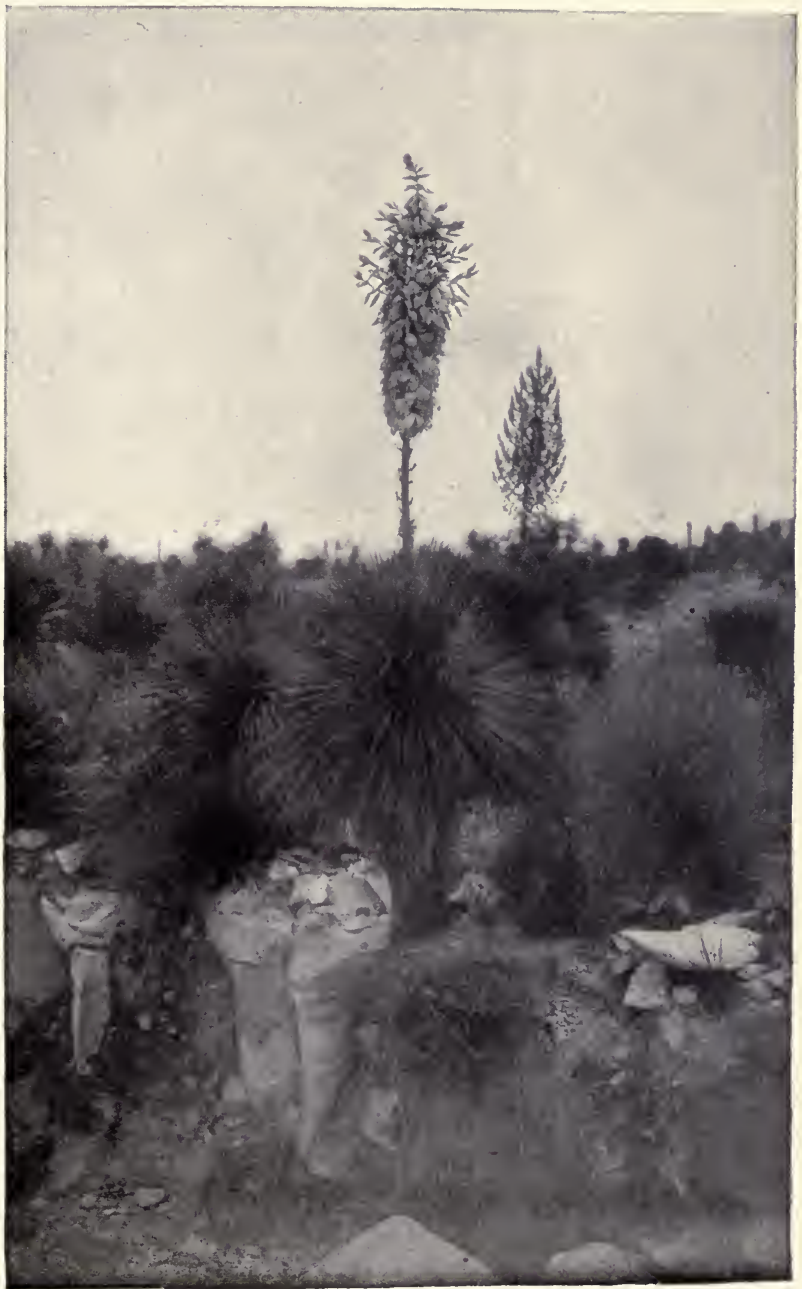

YUCCA ROSTRATA. 



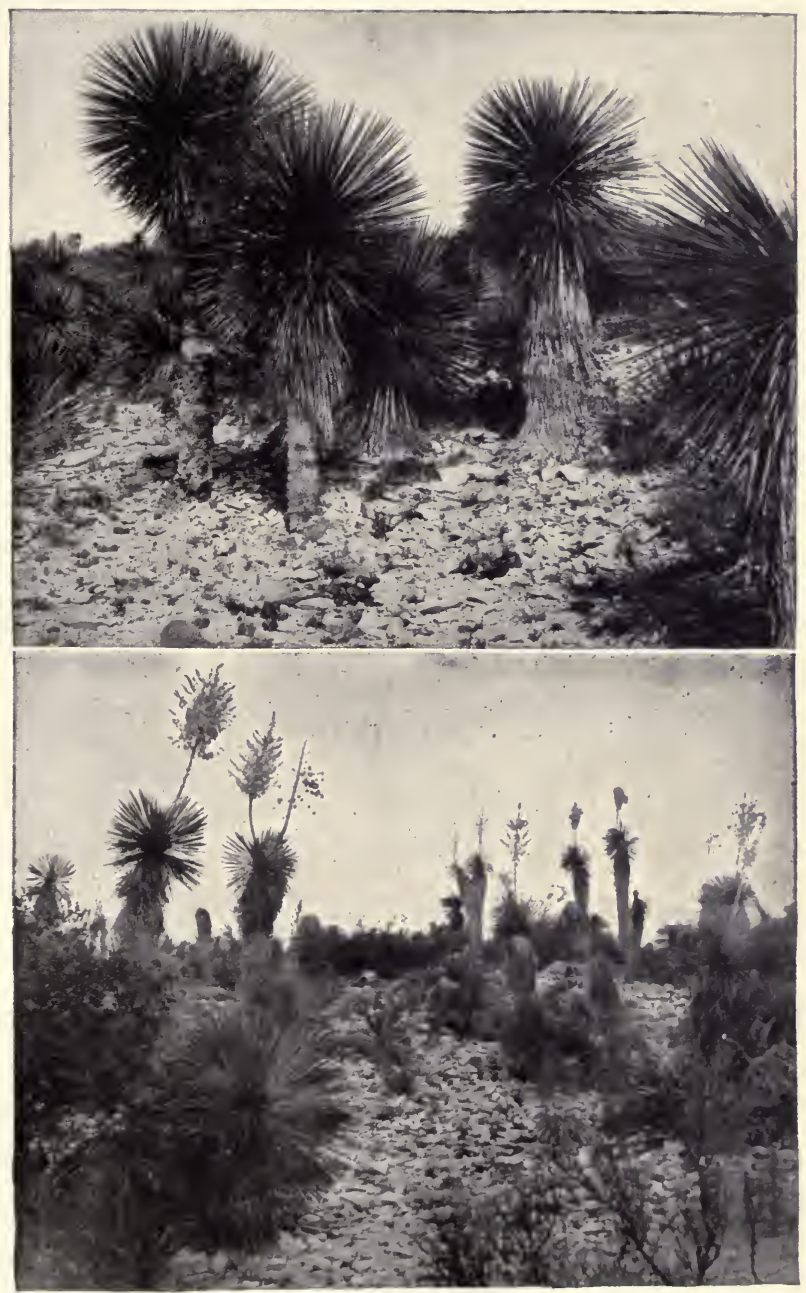





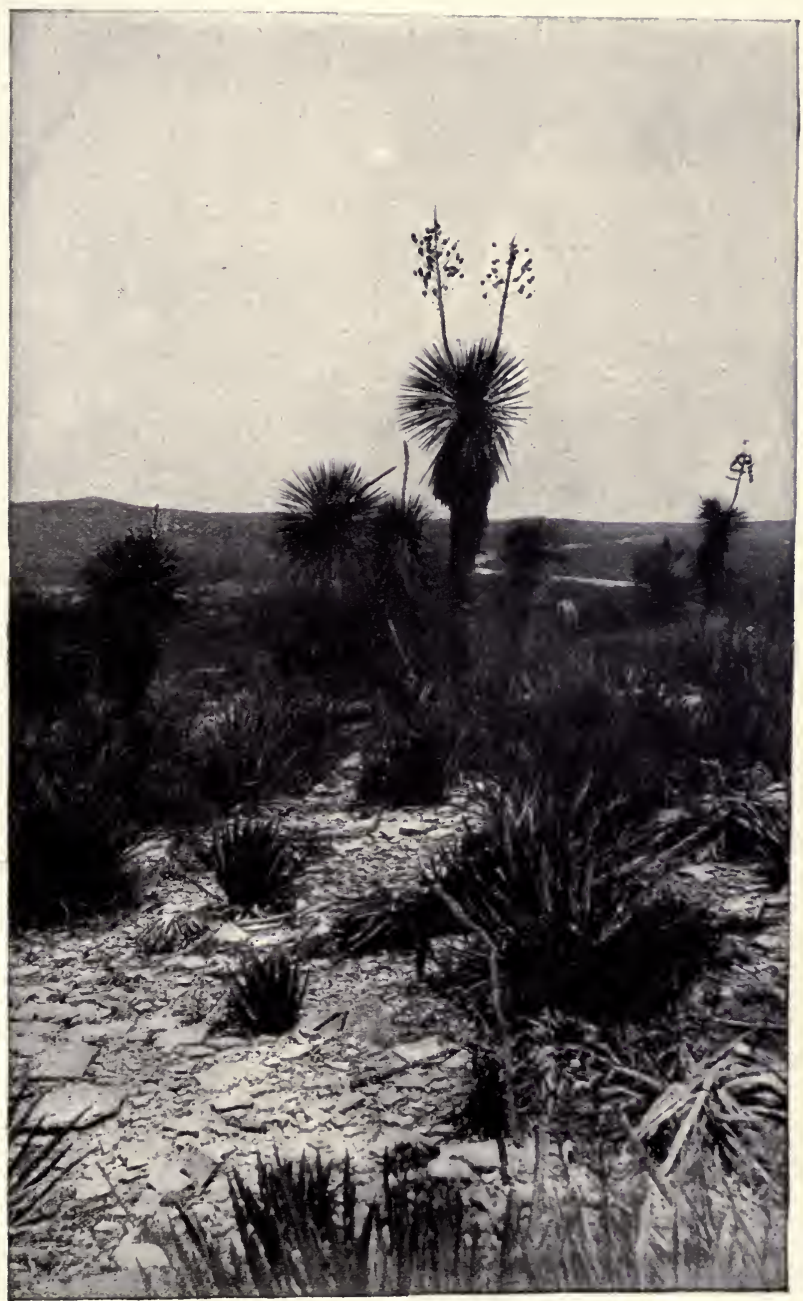





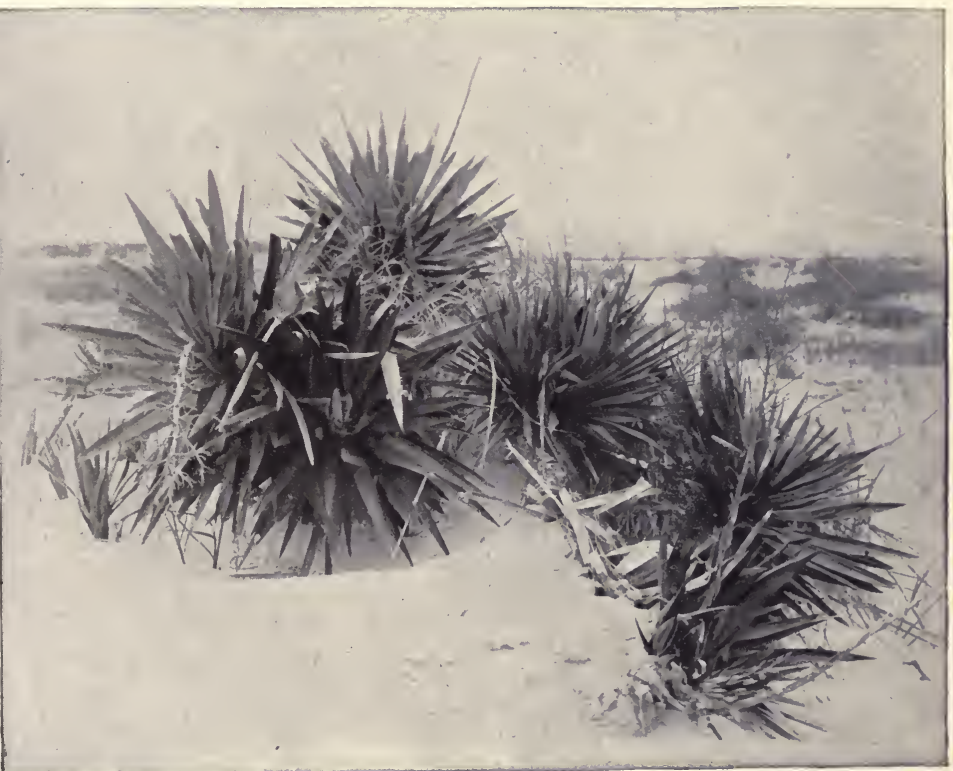





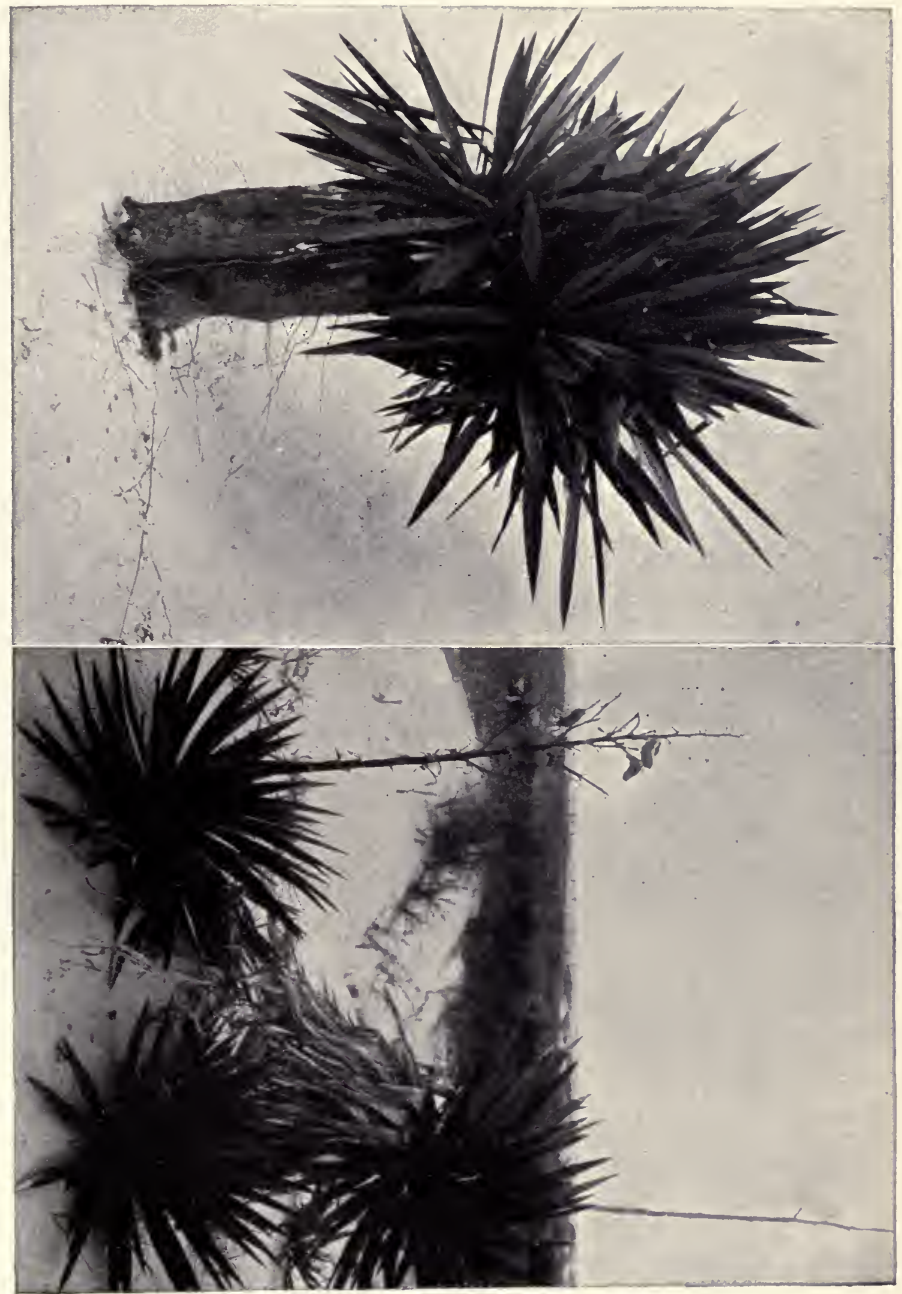





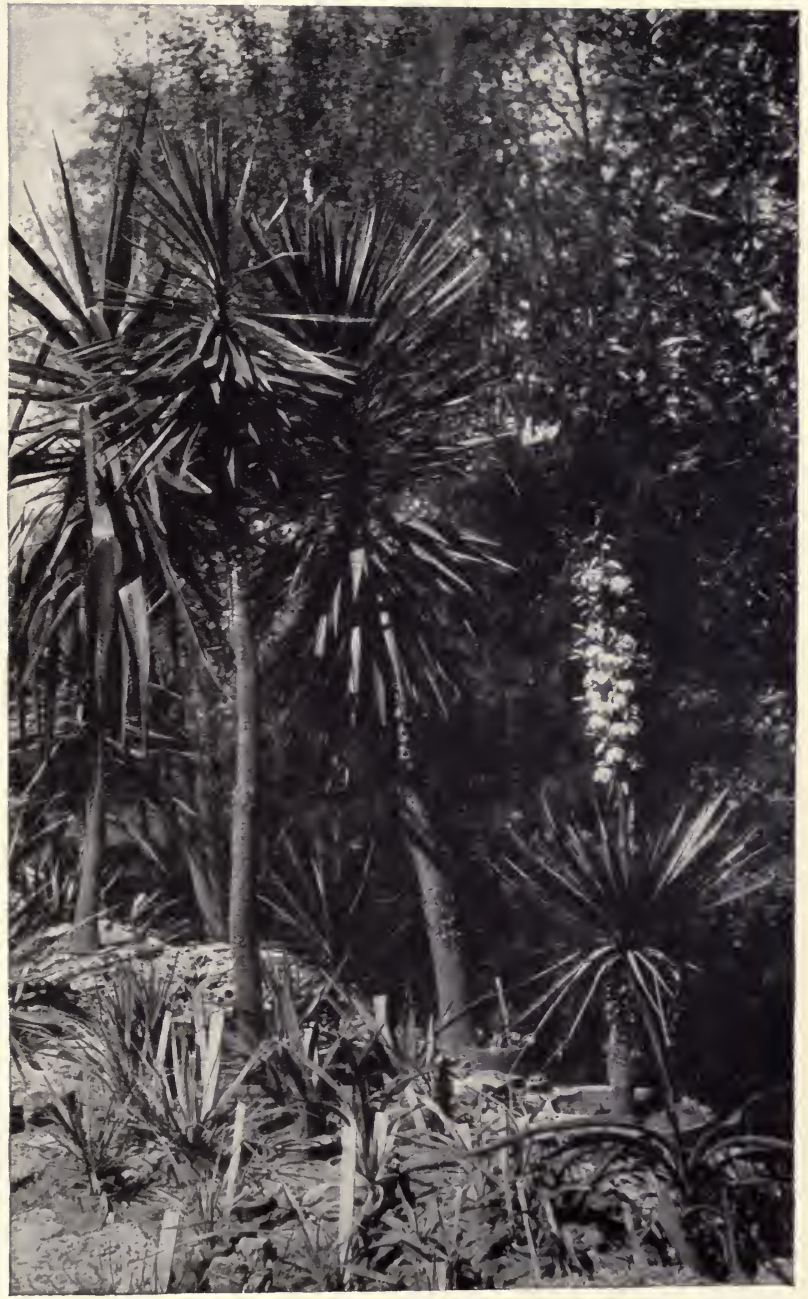




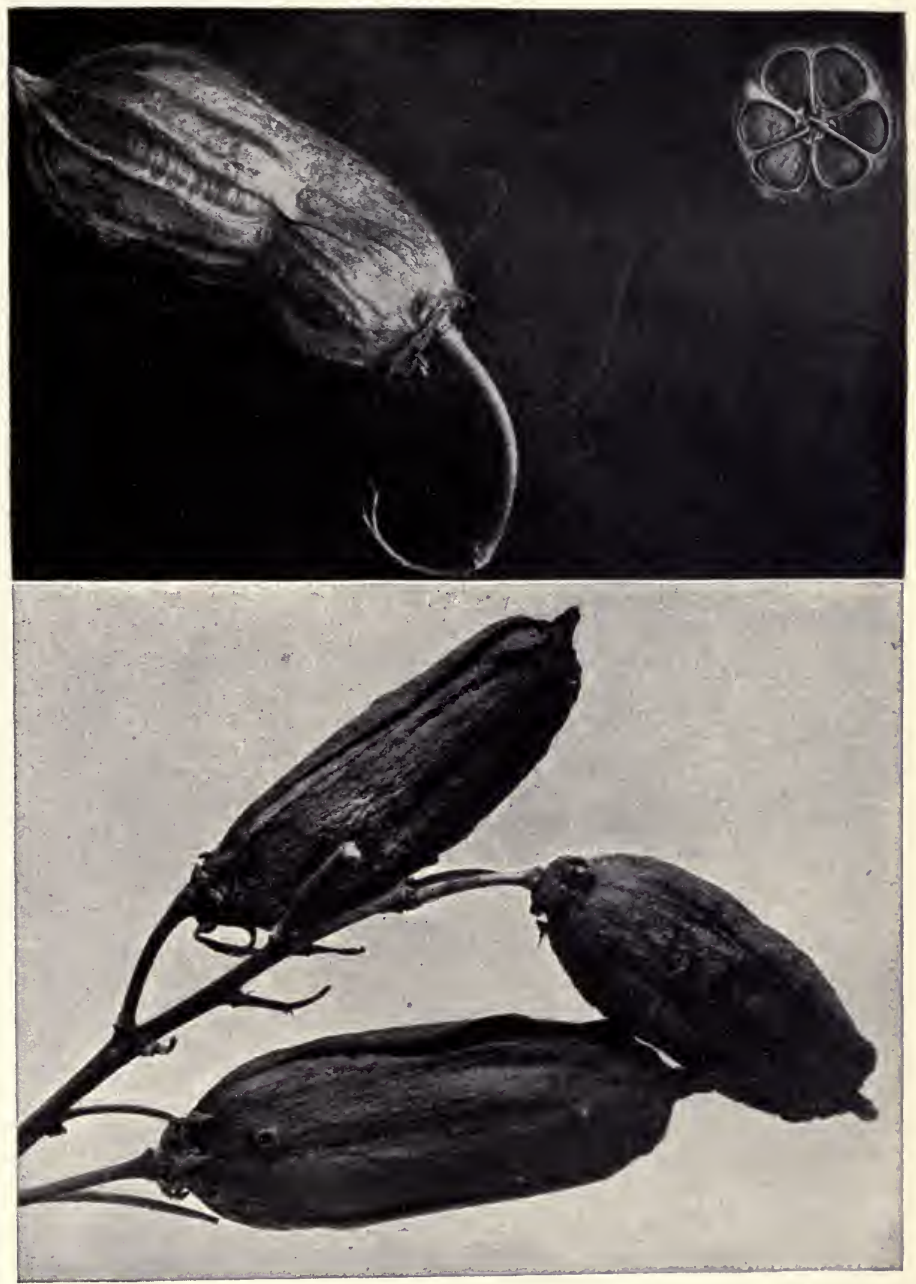

YUCCA GLORIOSA AND Y. RECURVIFOLIA. 


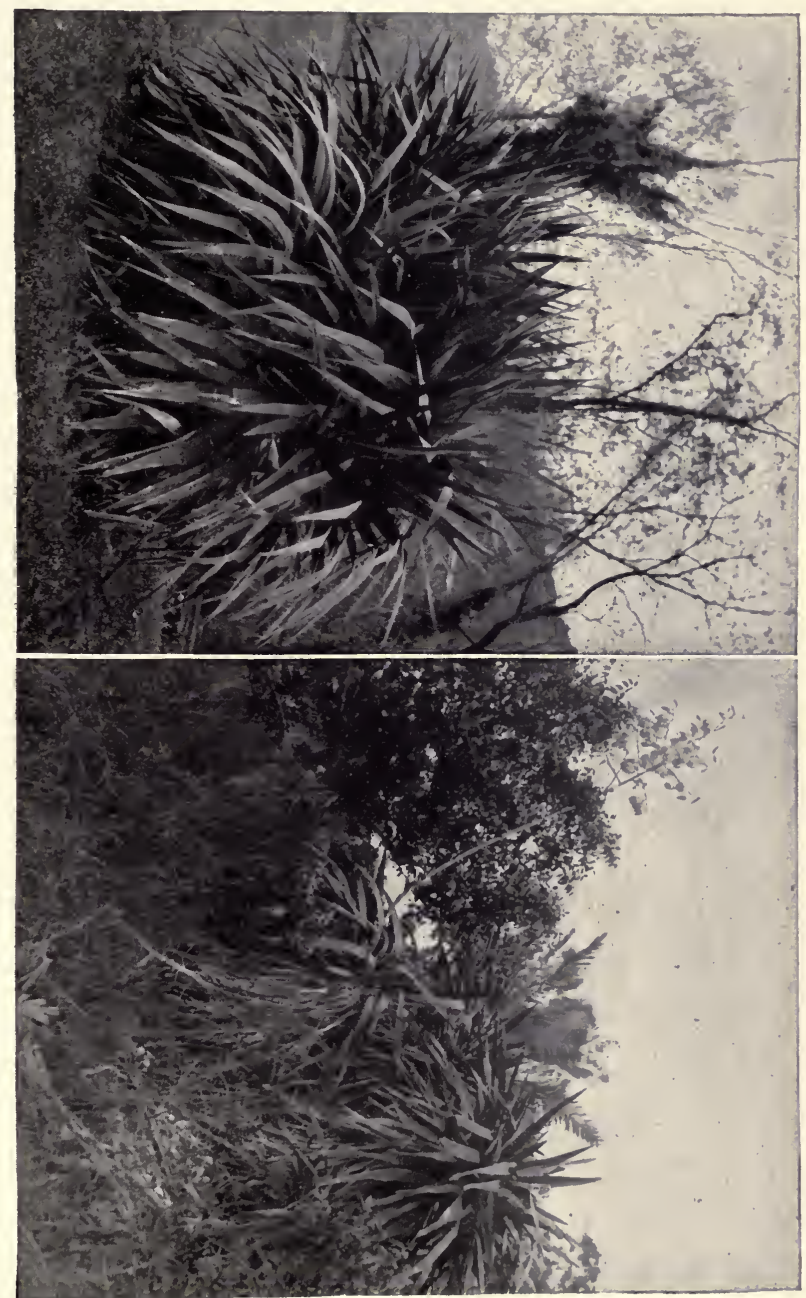



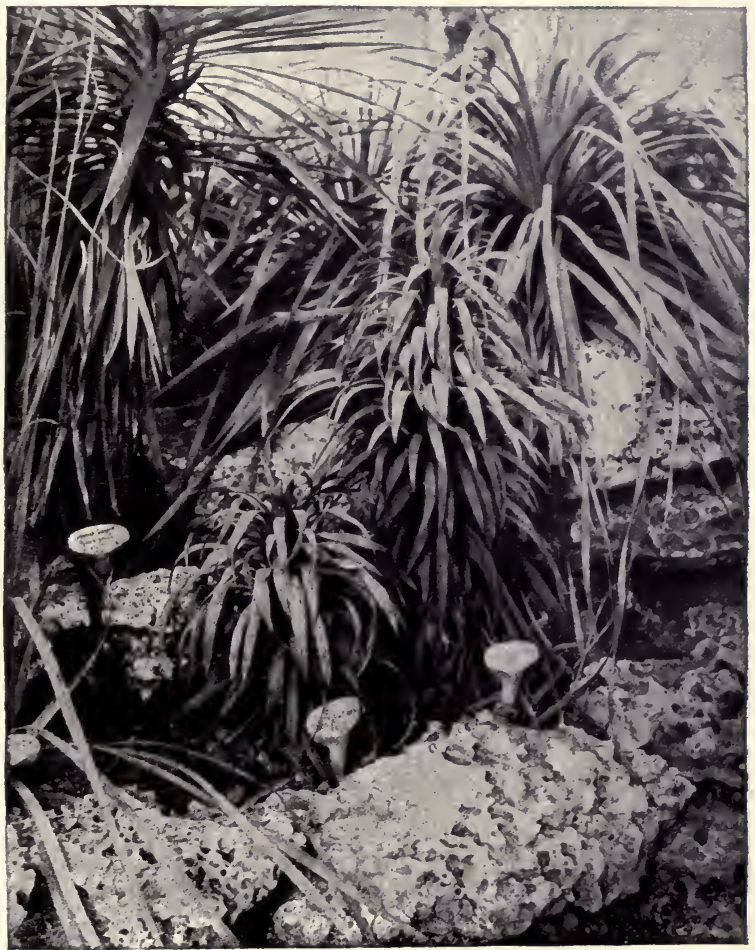





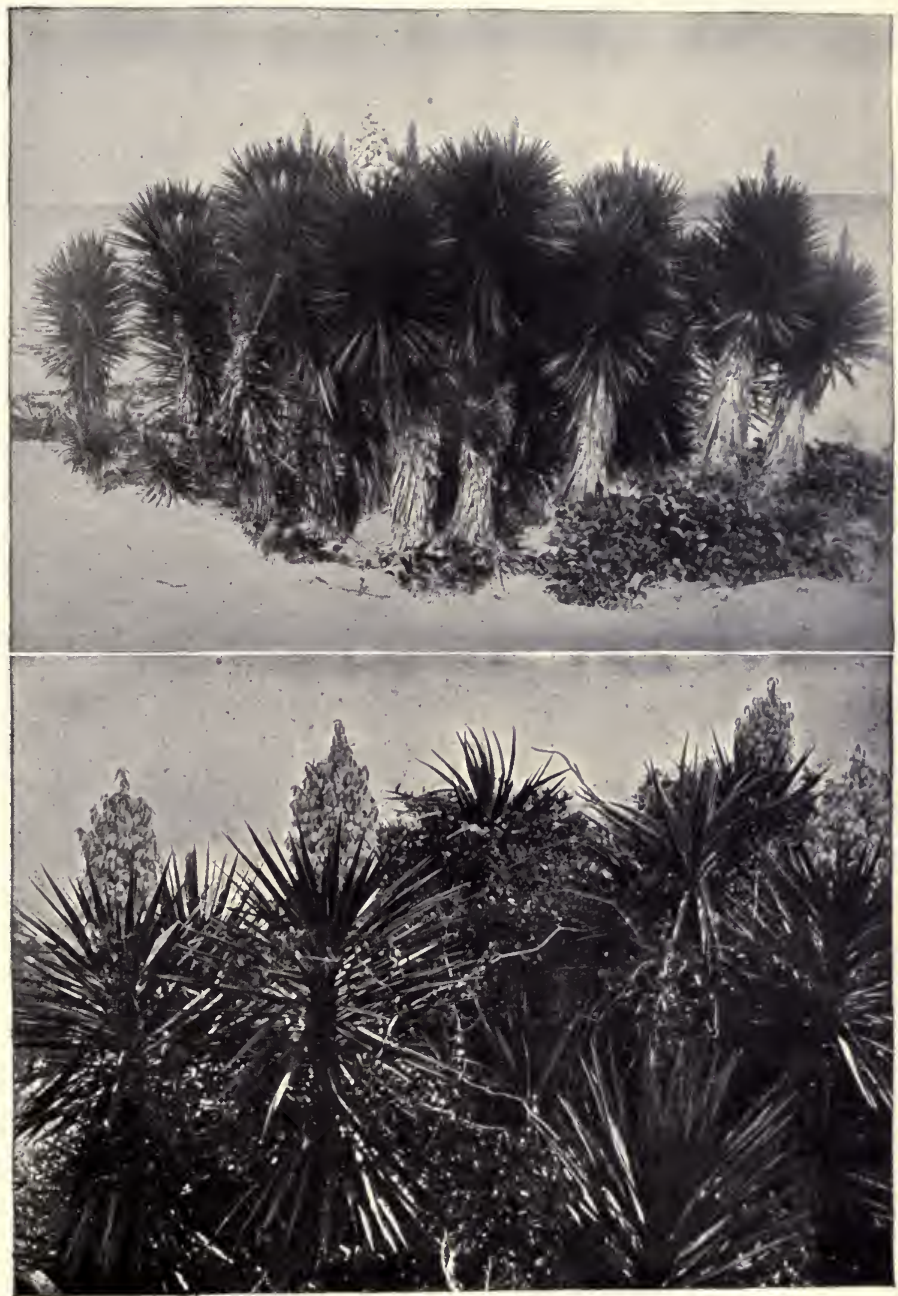





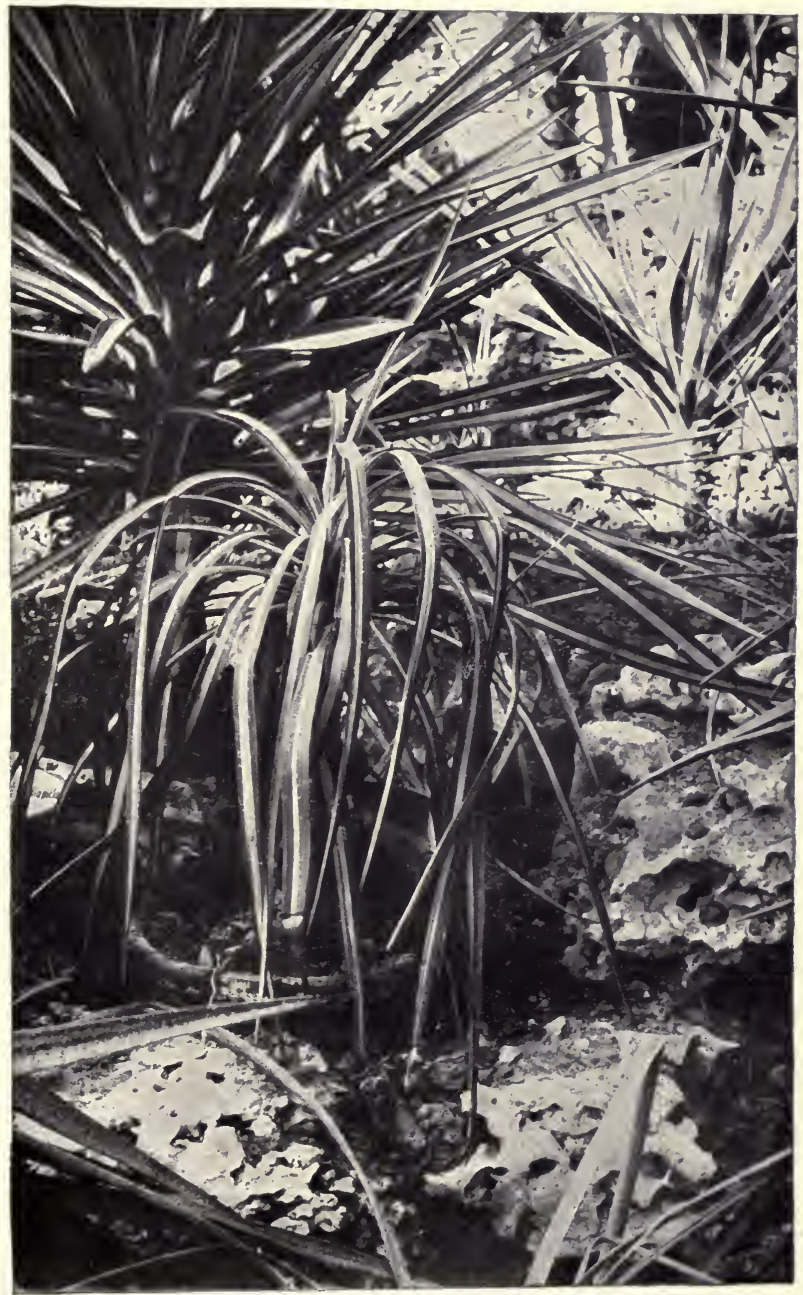




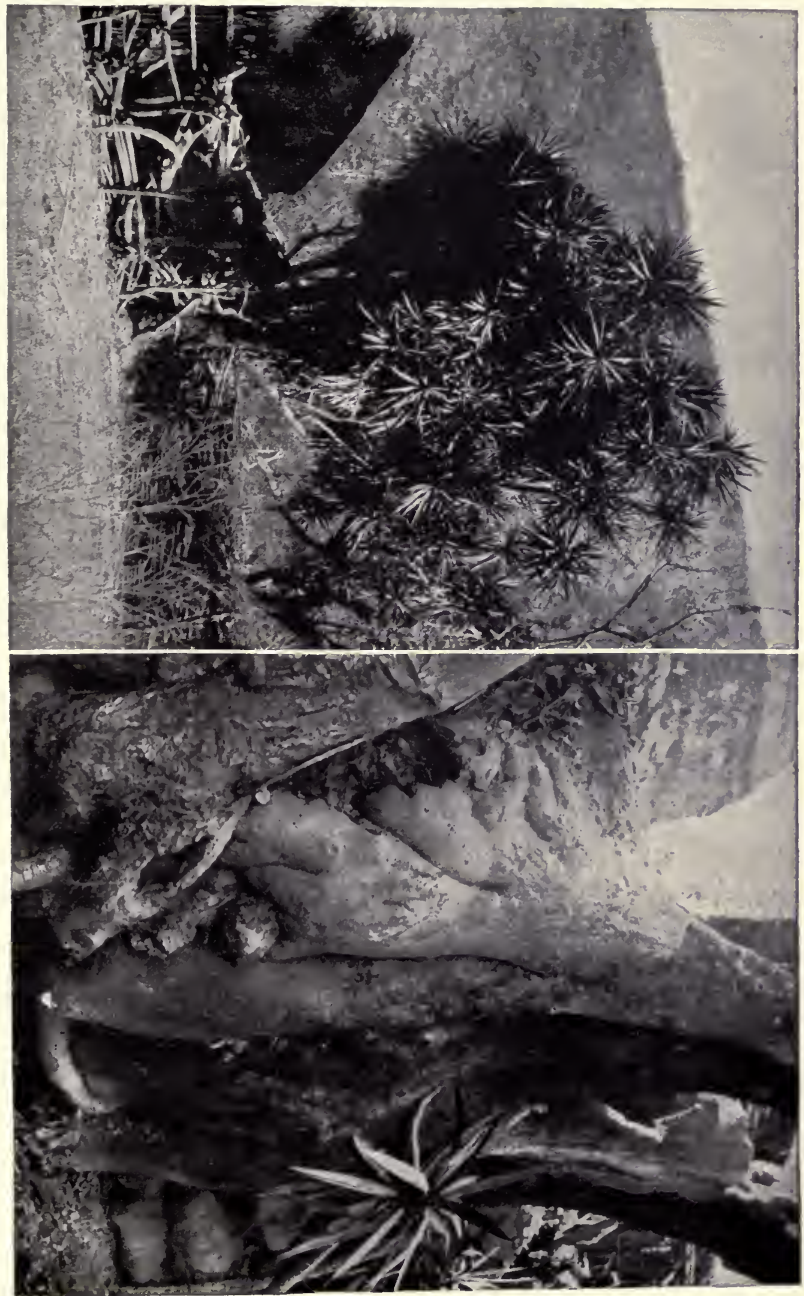

YUCCA ELEPHANTIPES. 


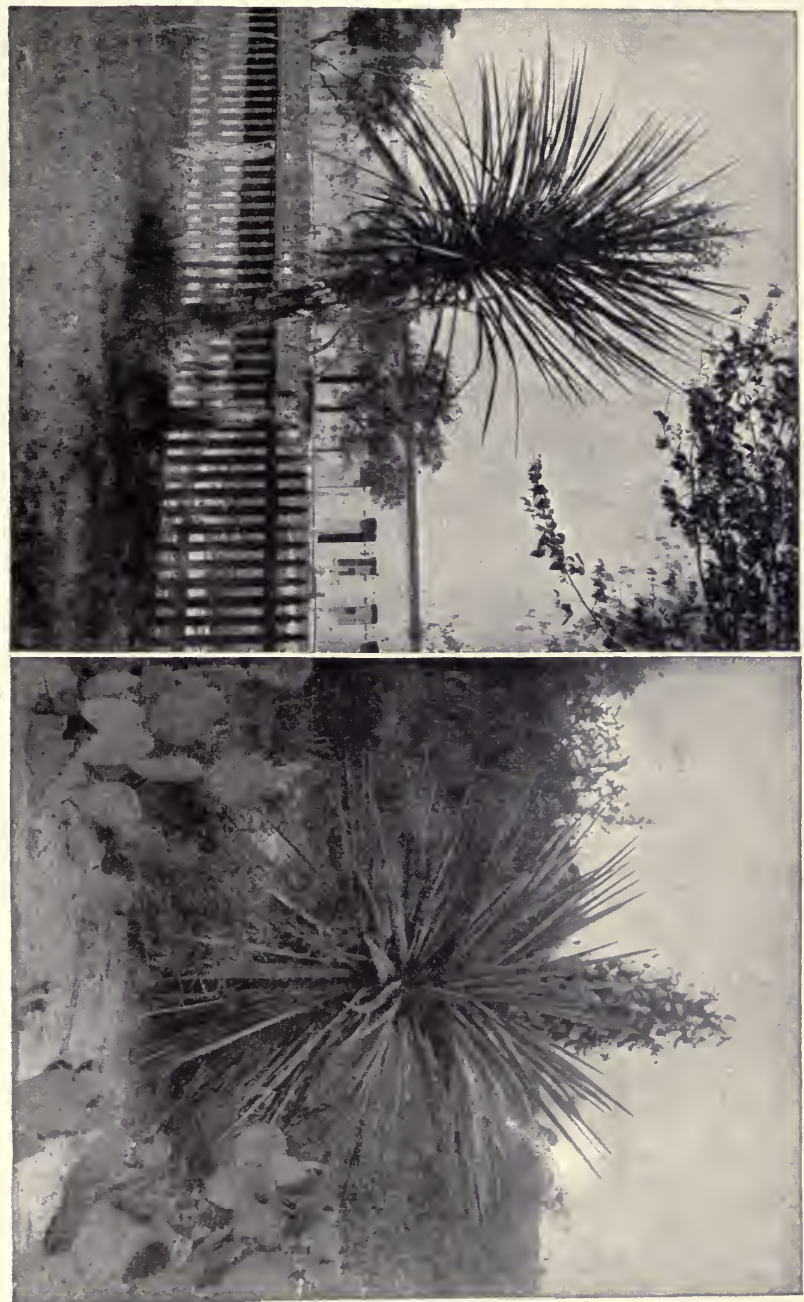

YUCCA TRECULEANA. 



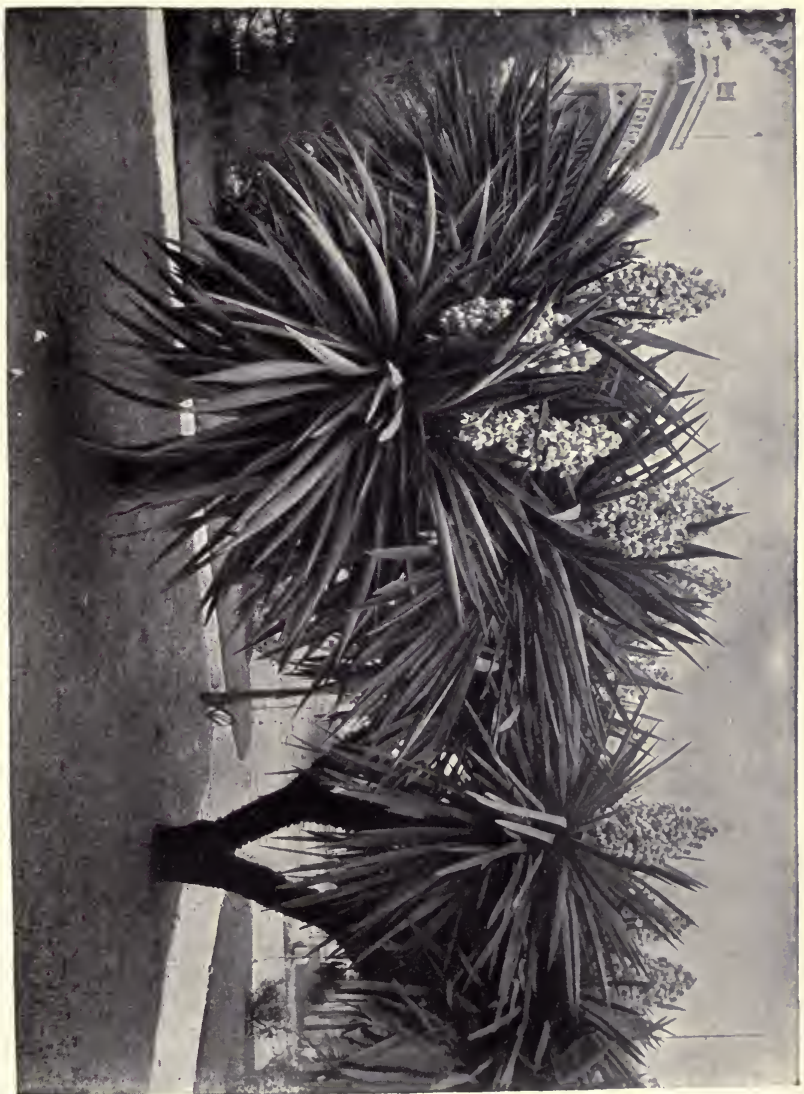





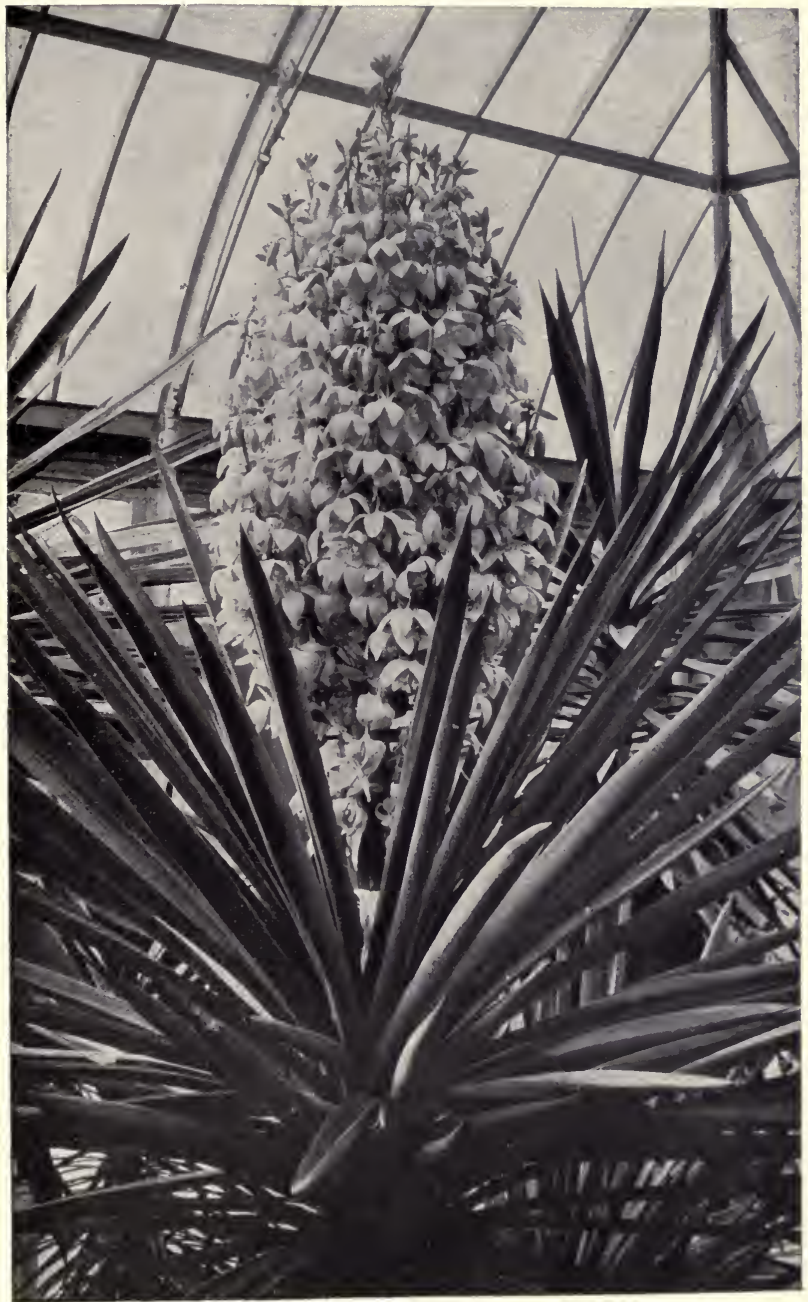




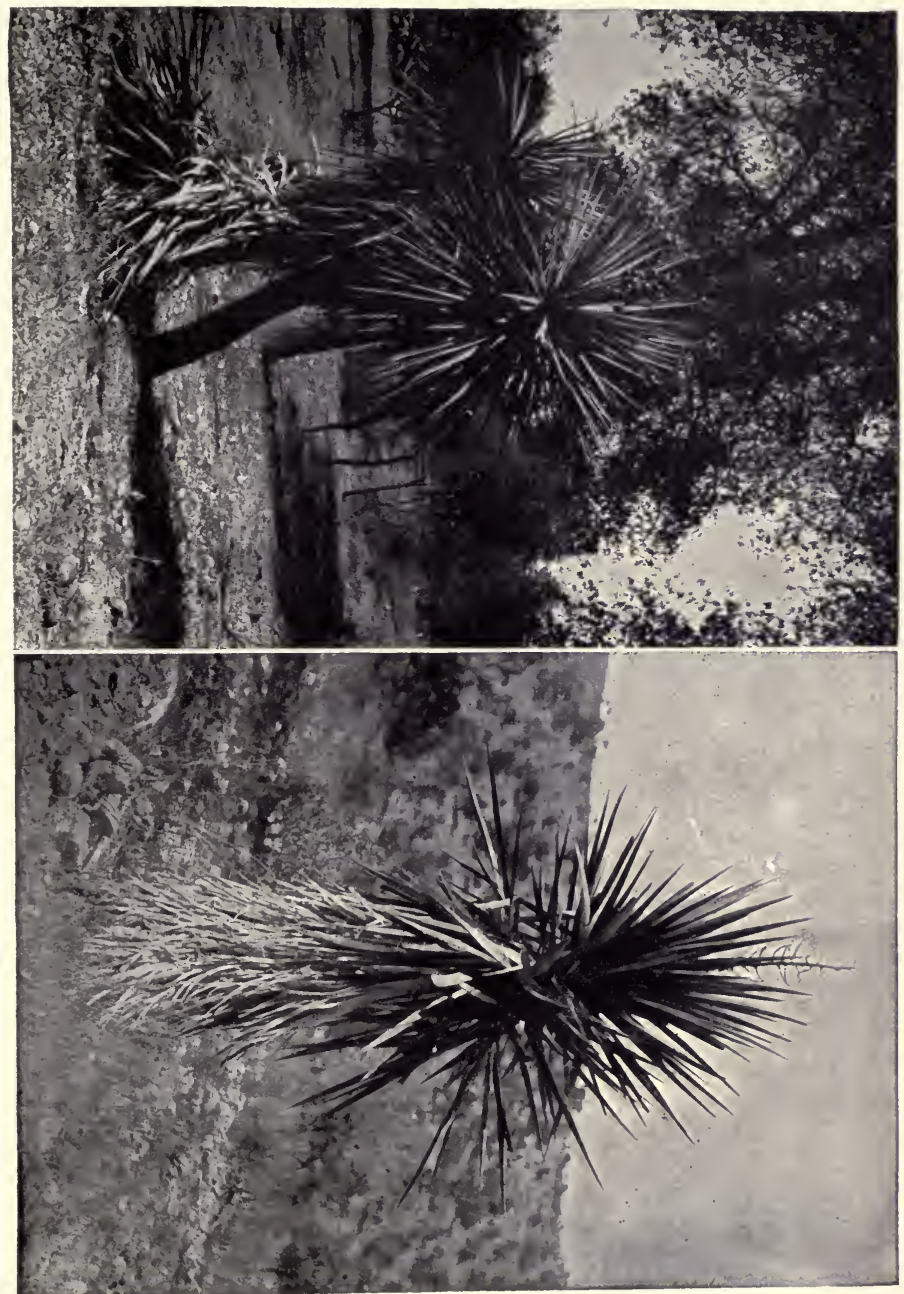


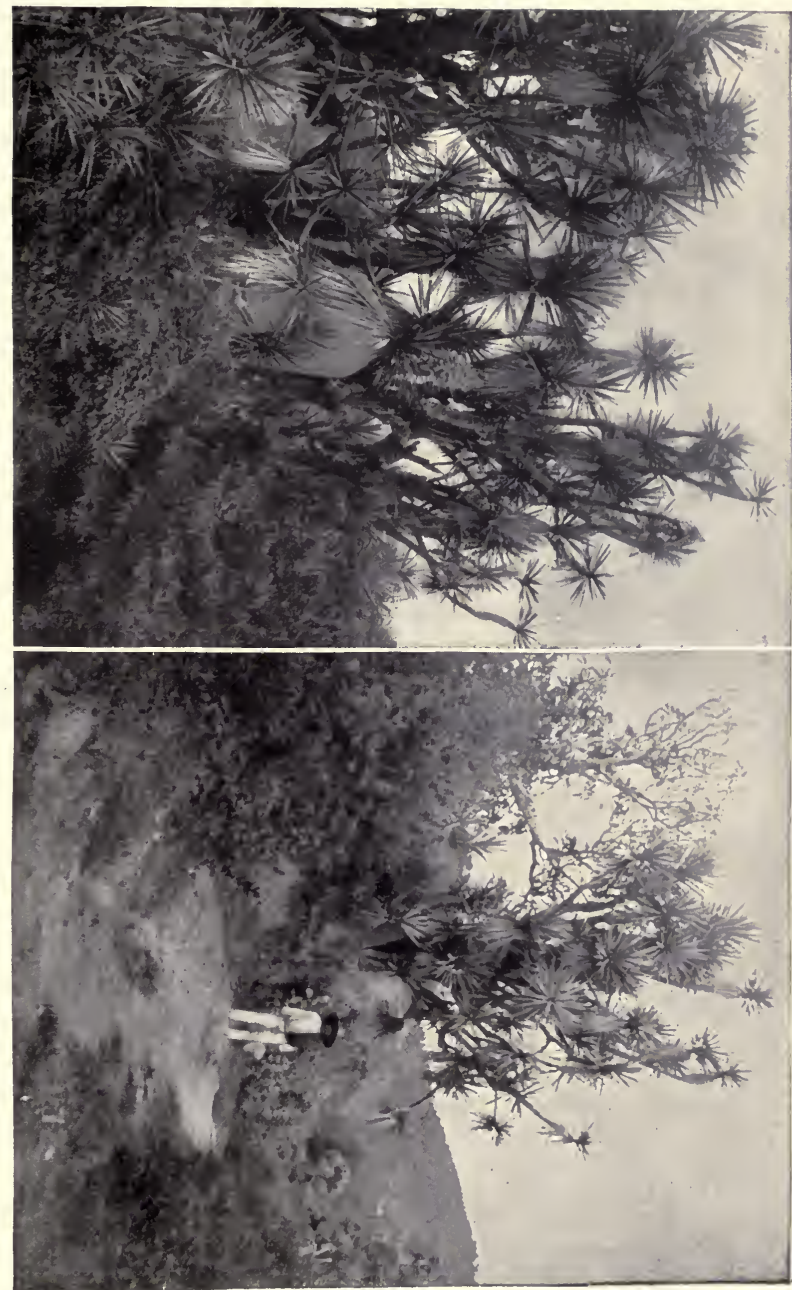



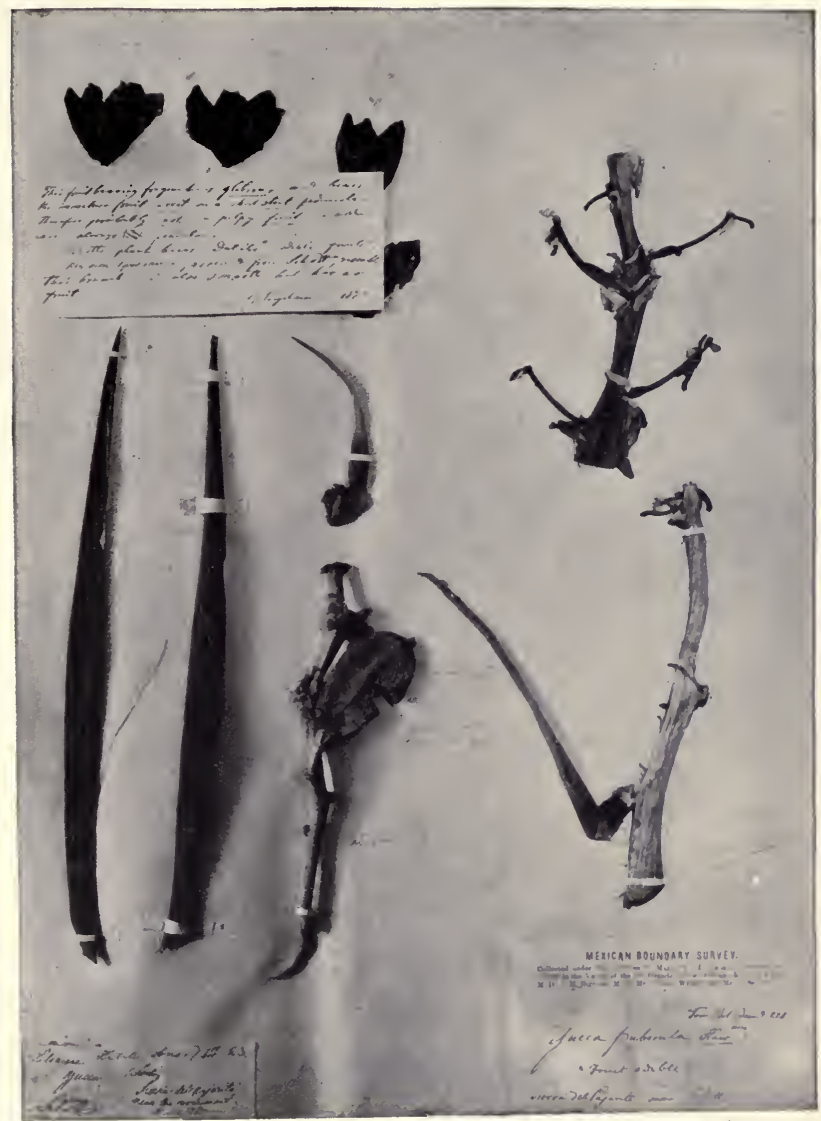




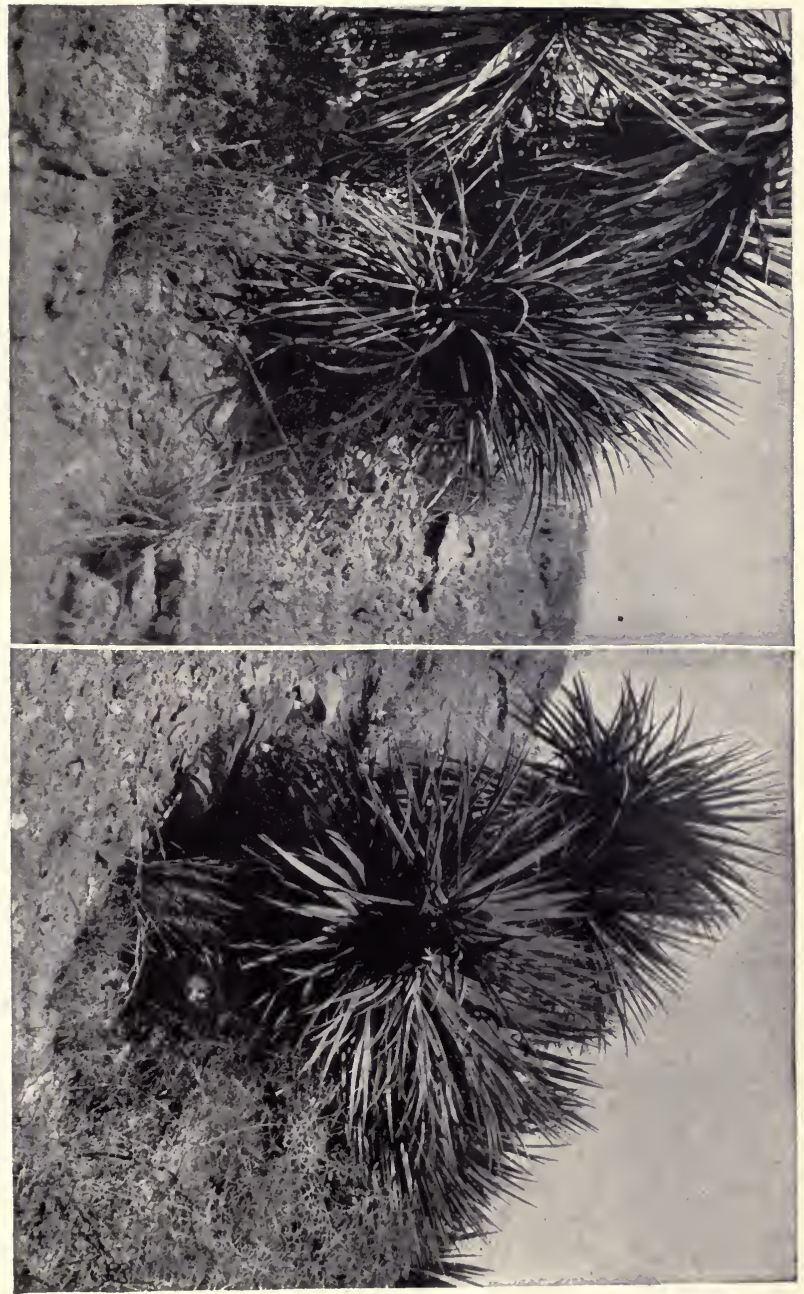



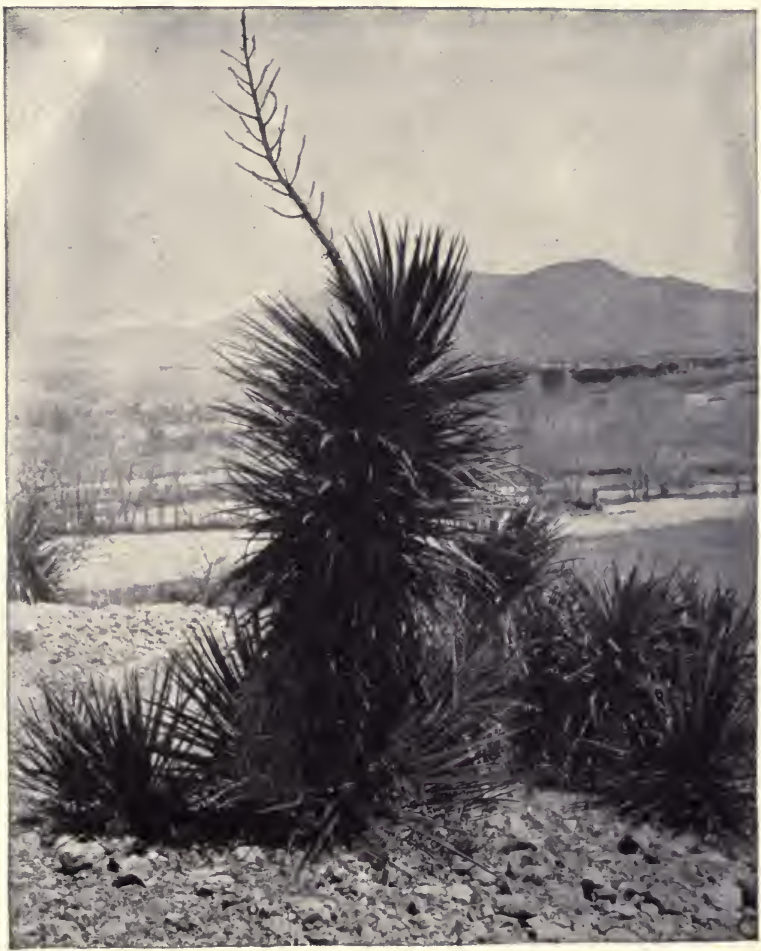





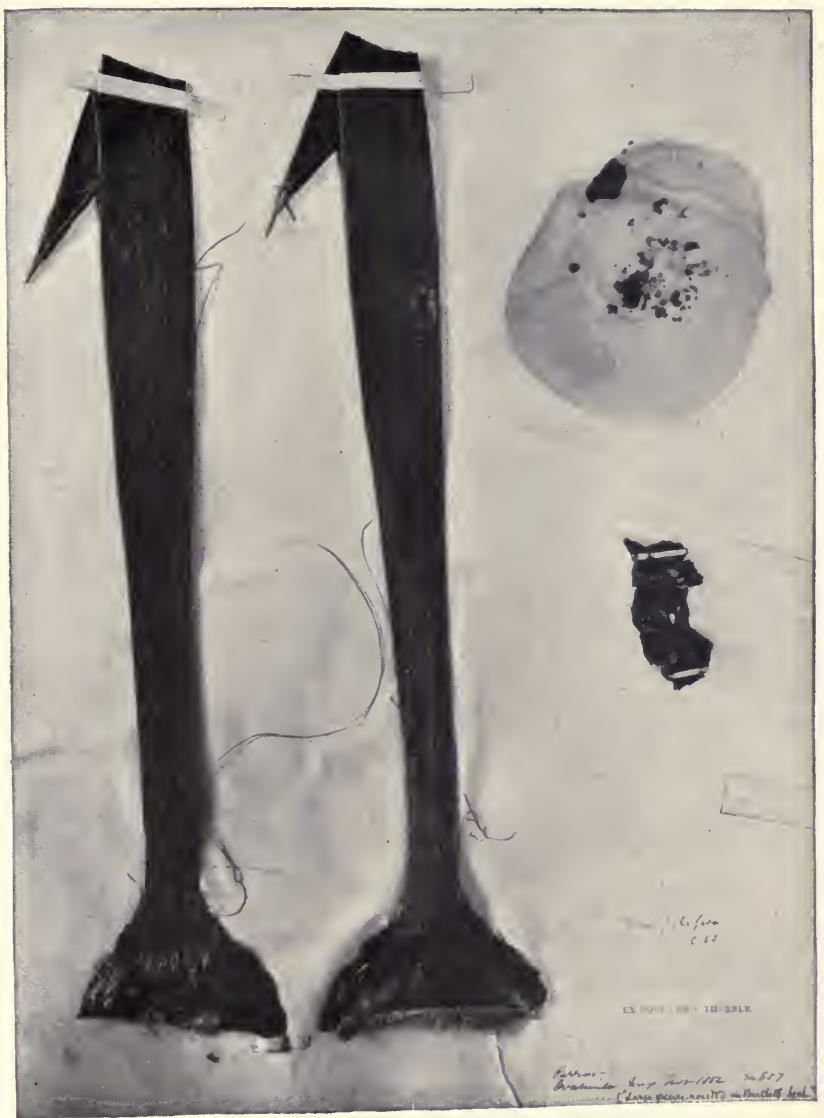





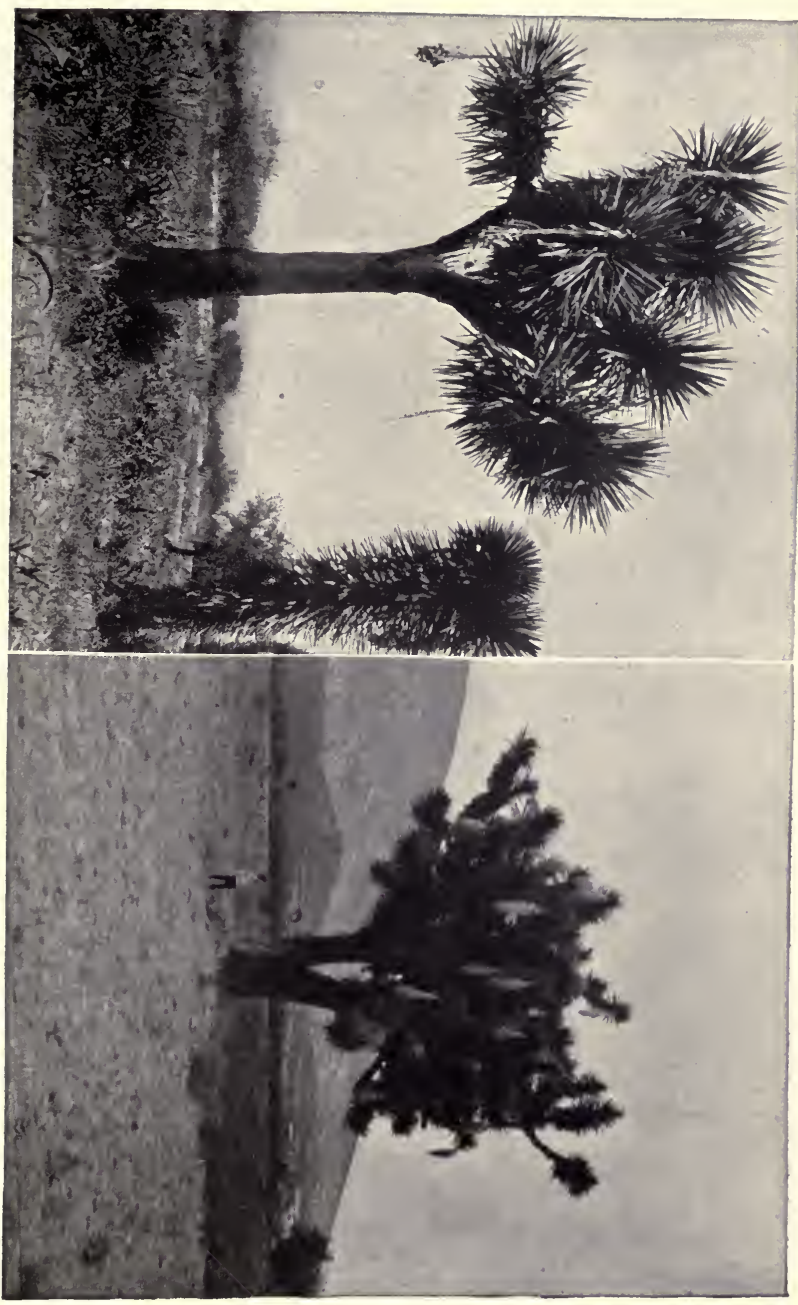





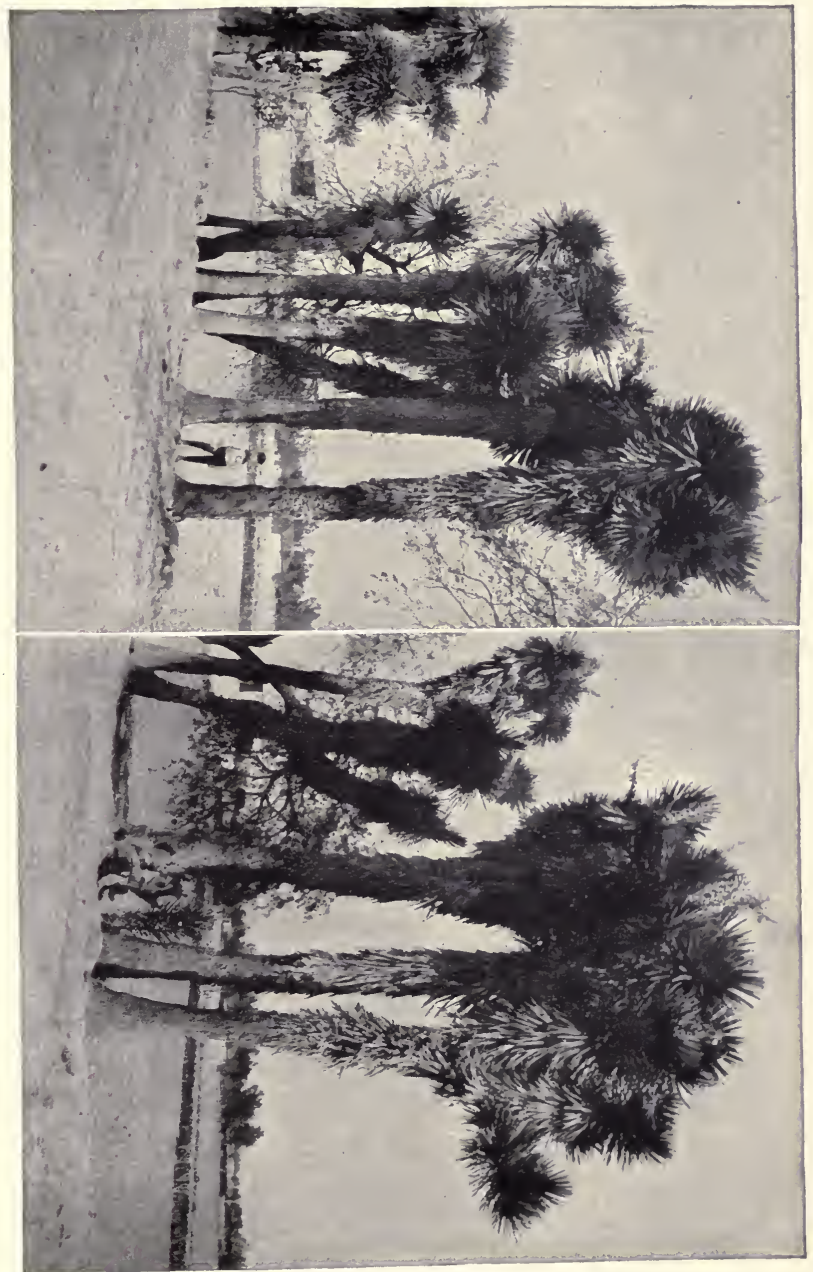



REPT. MO. BOT. GARD., Vol. 13.

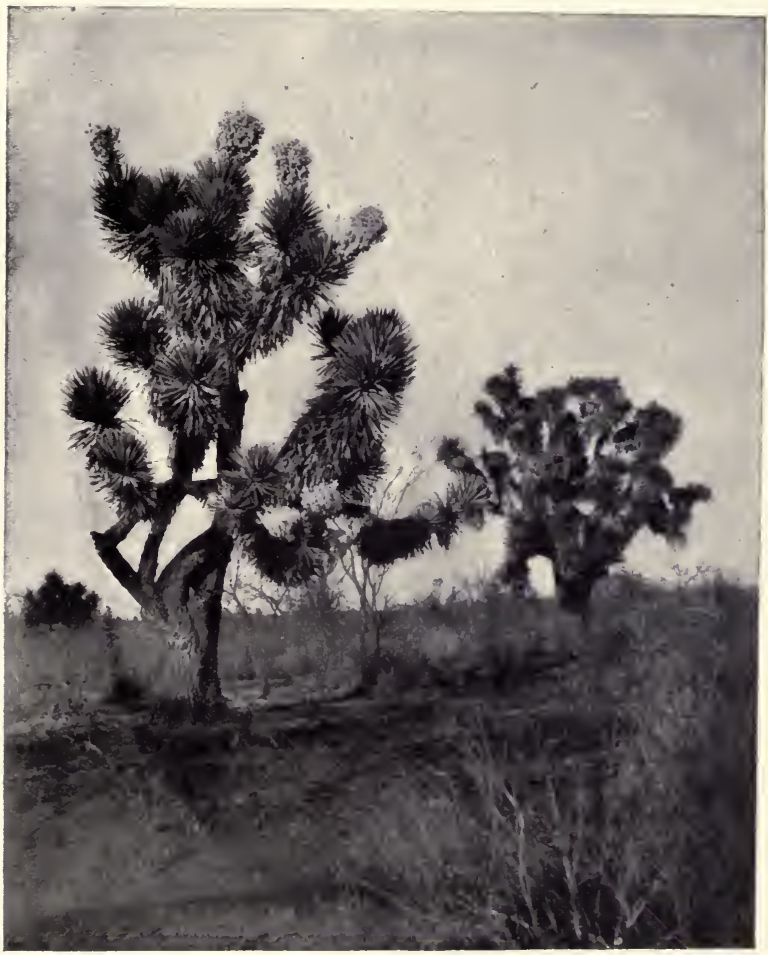





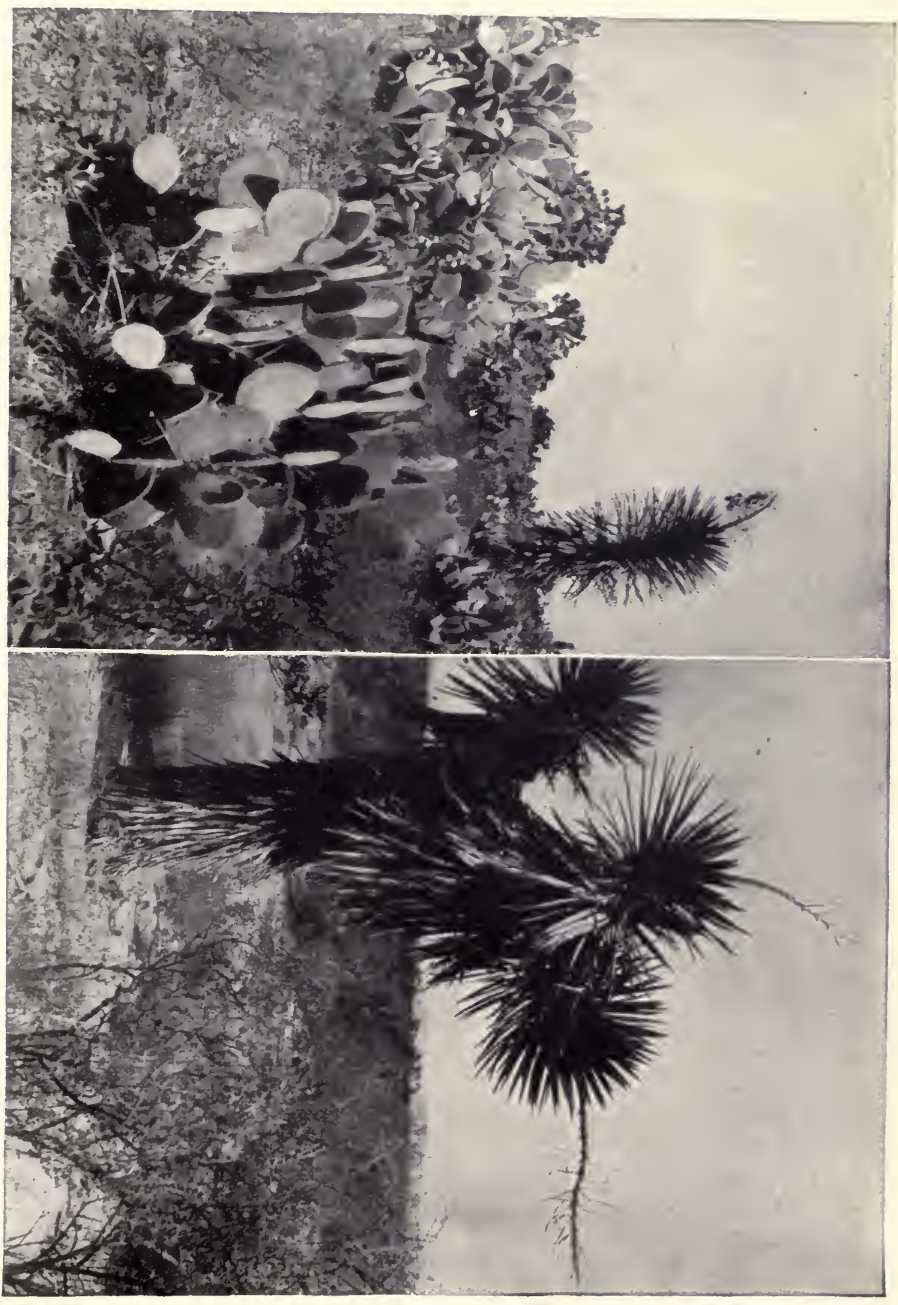





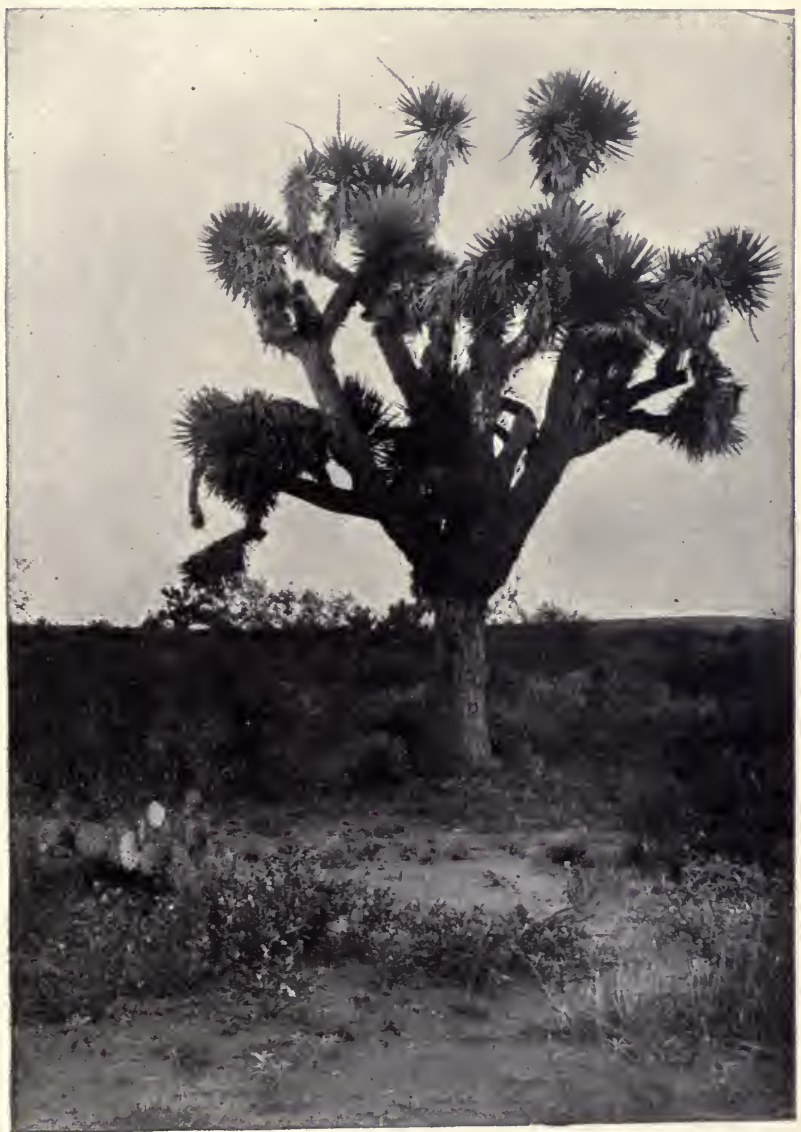





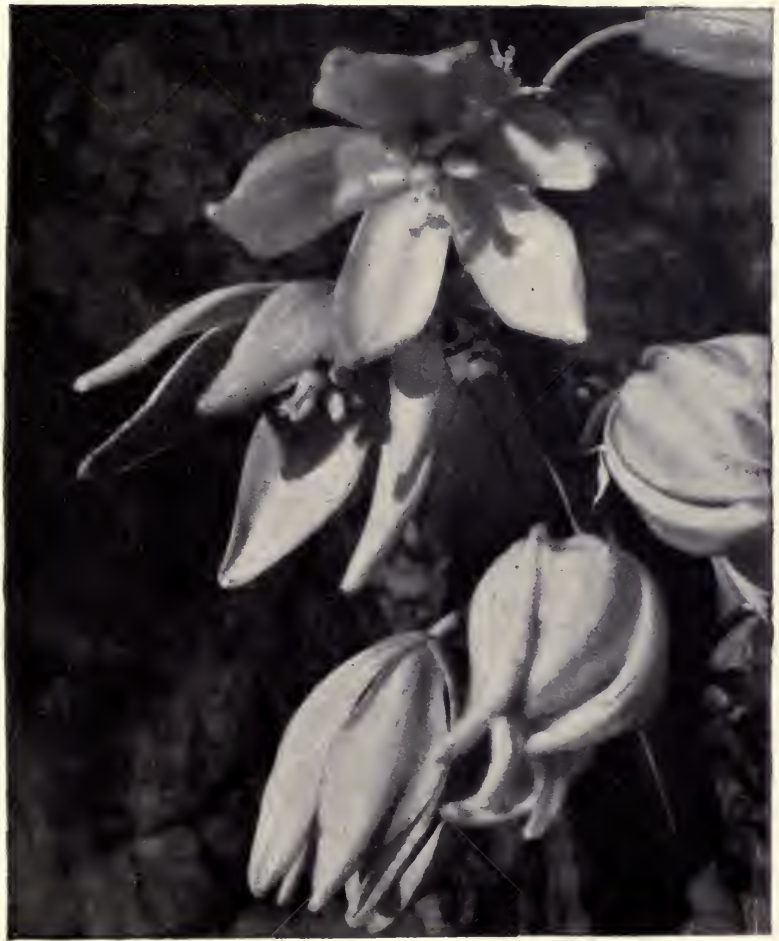




\section{.}




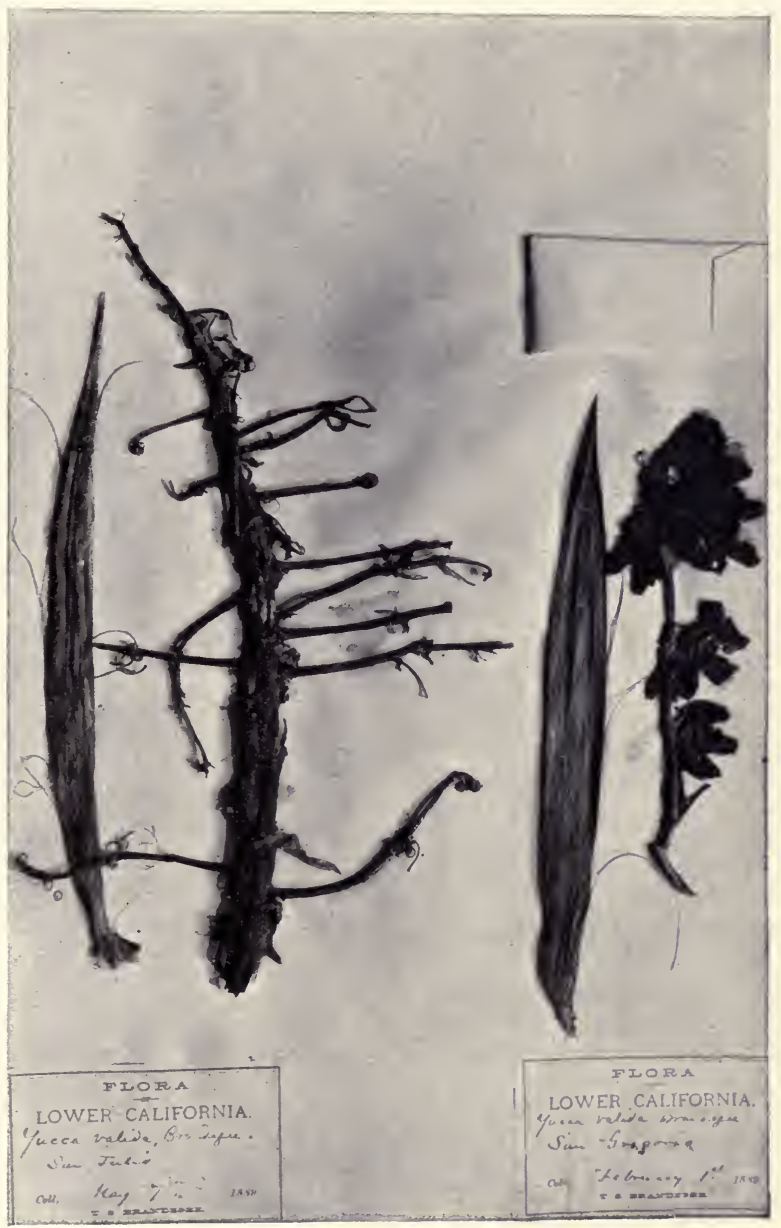





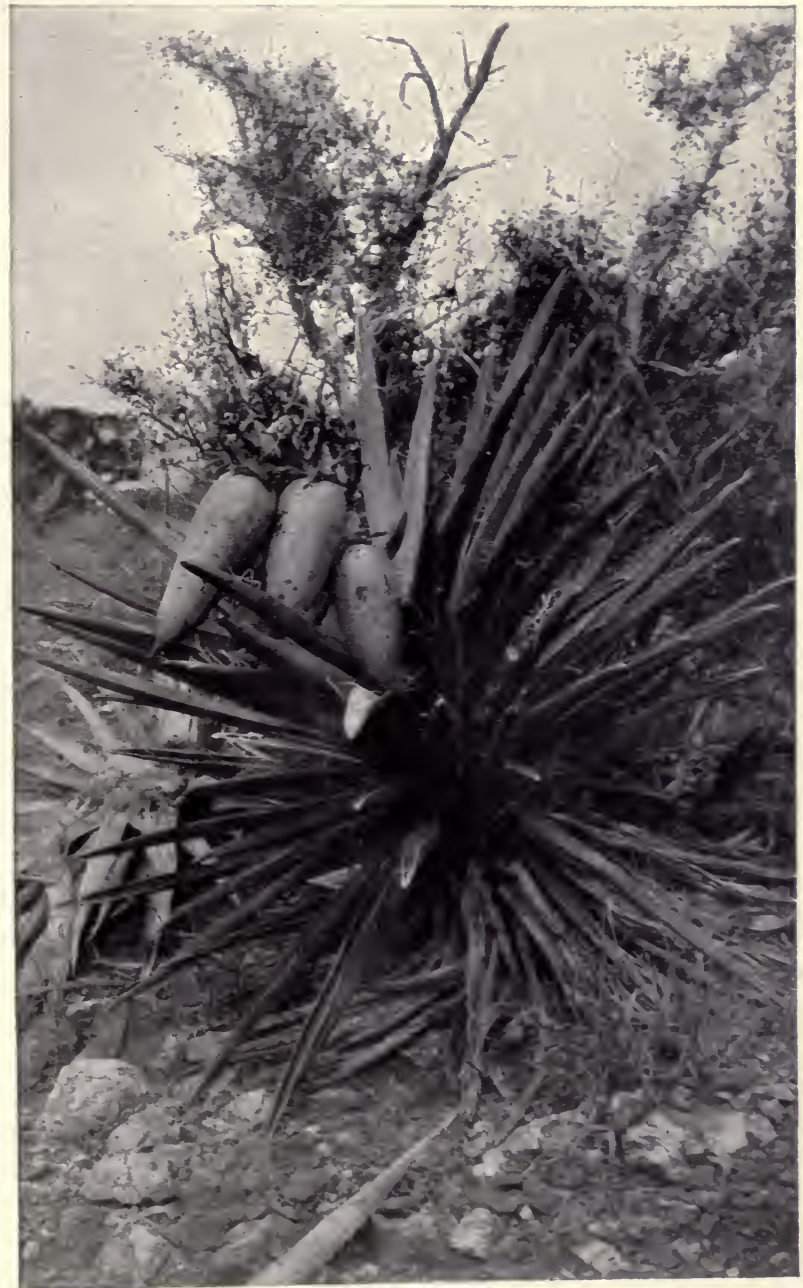





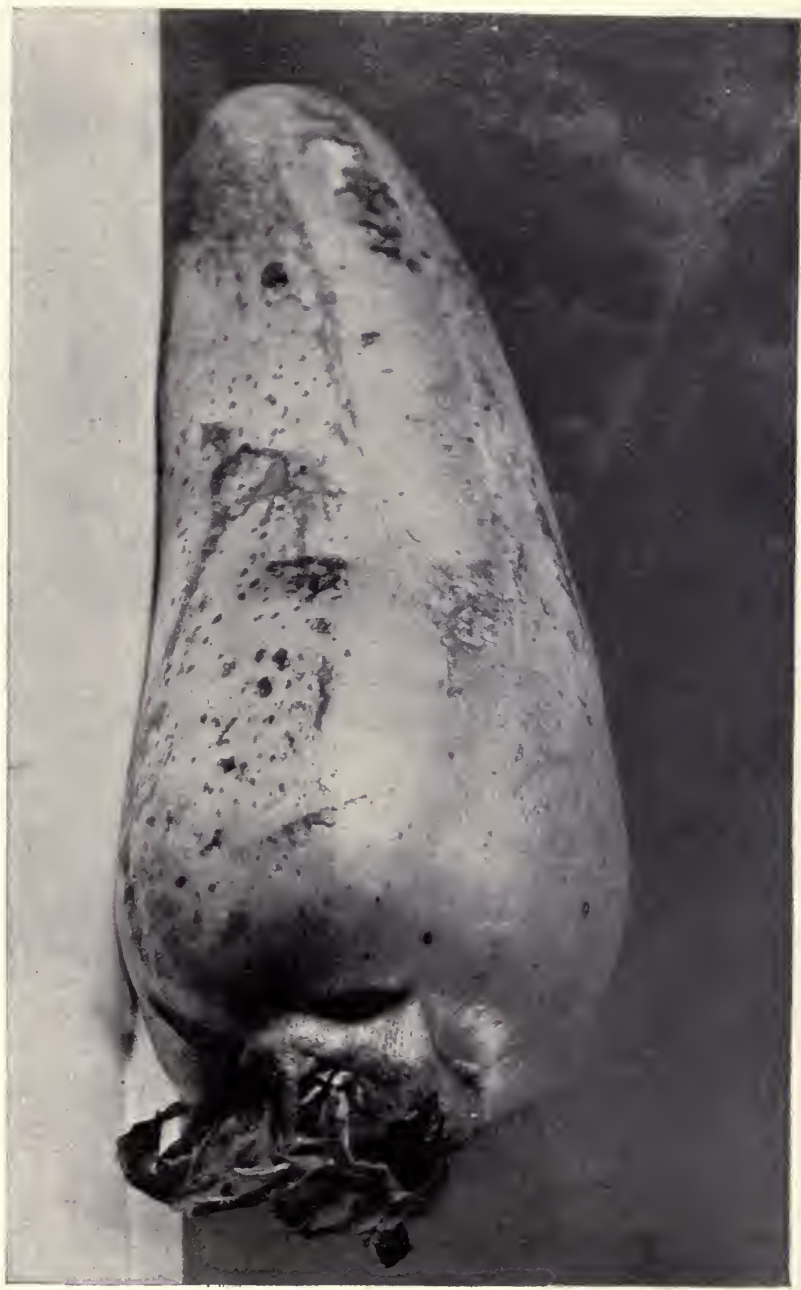





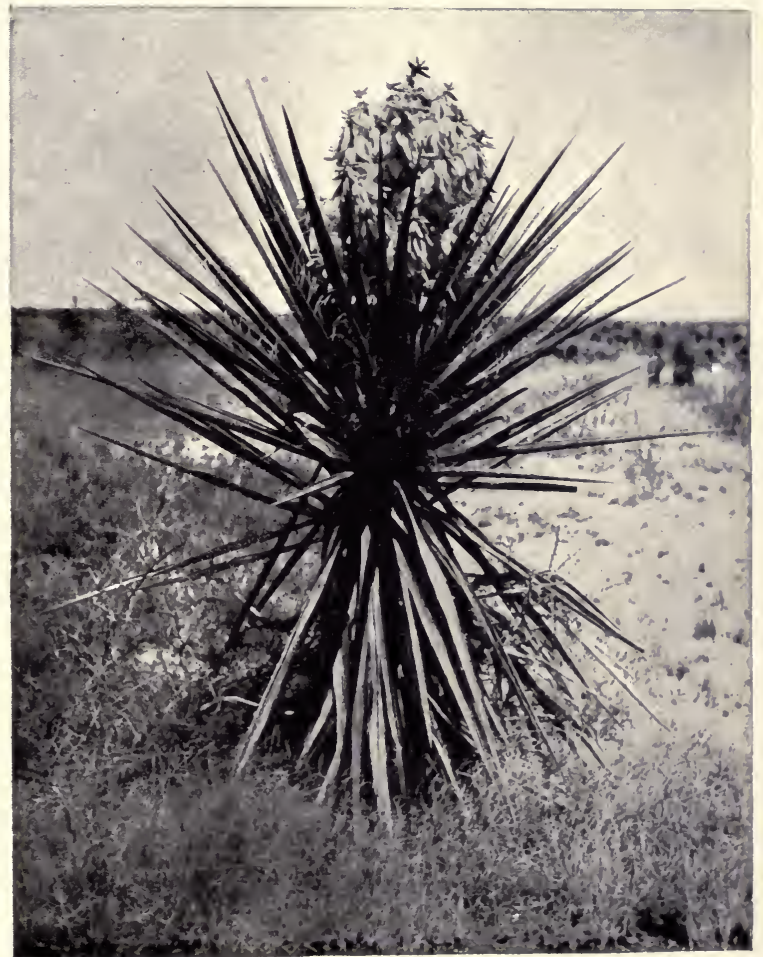




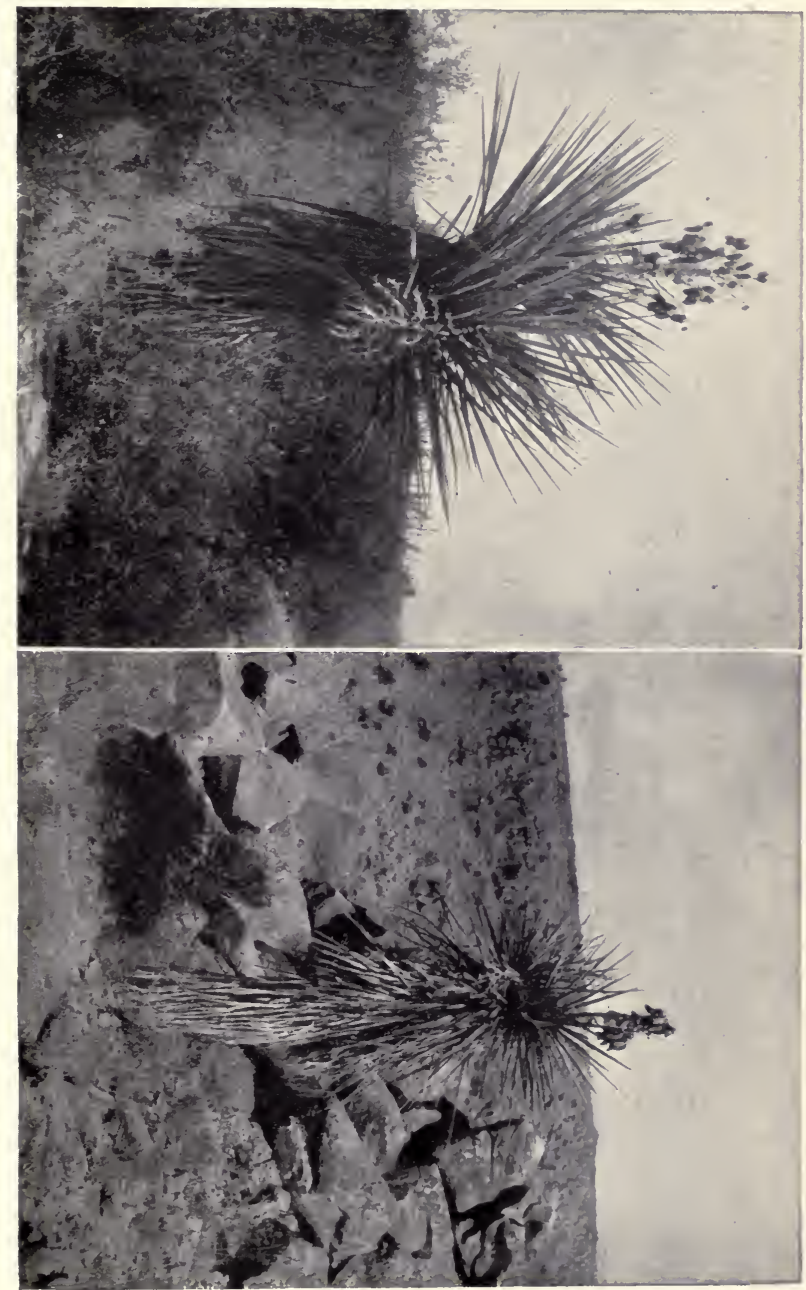


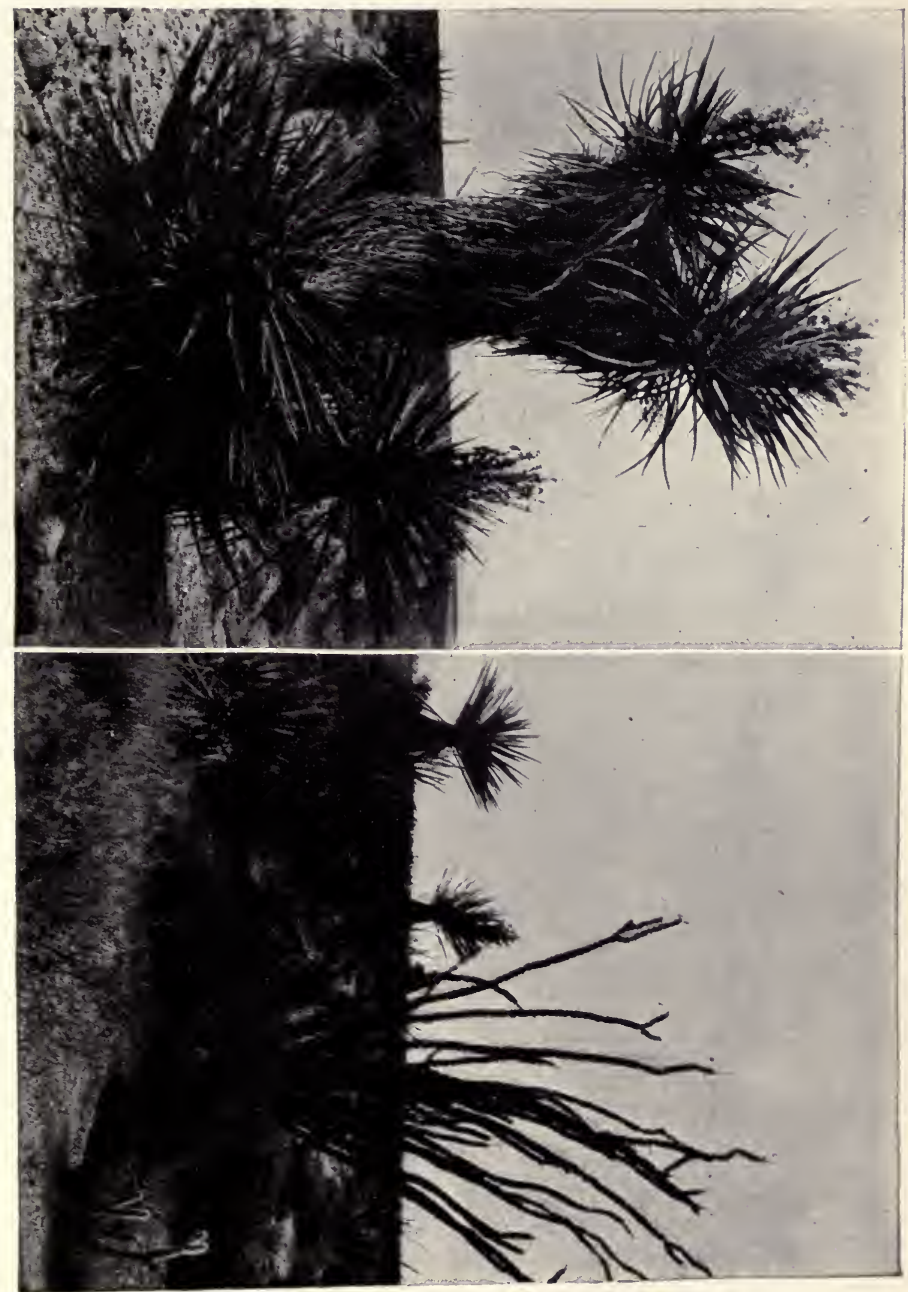



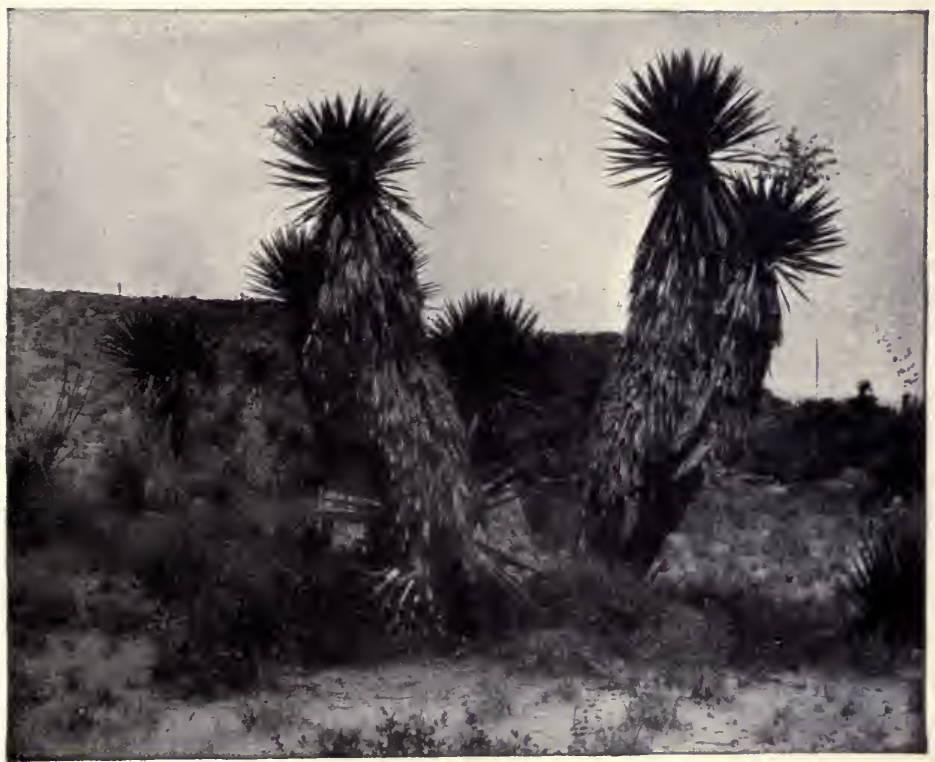




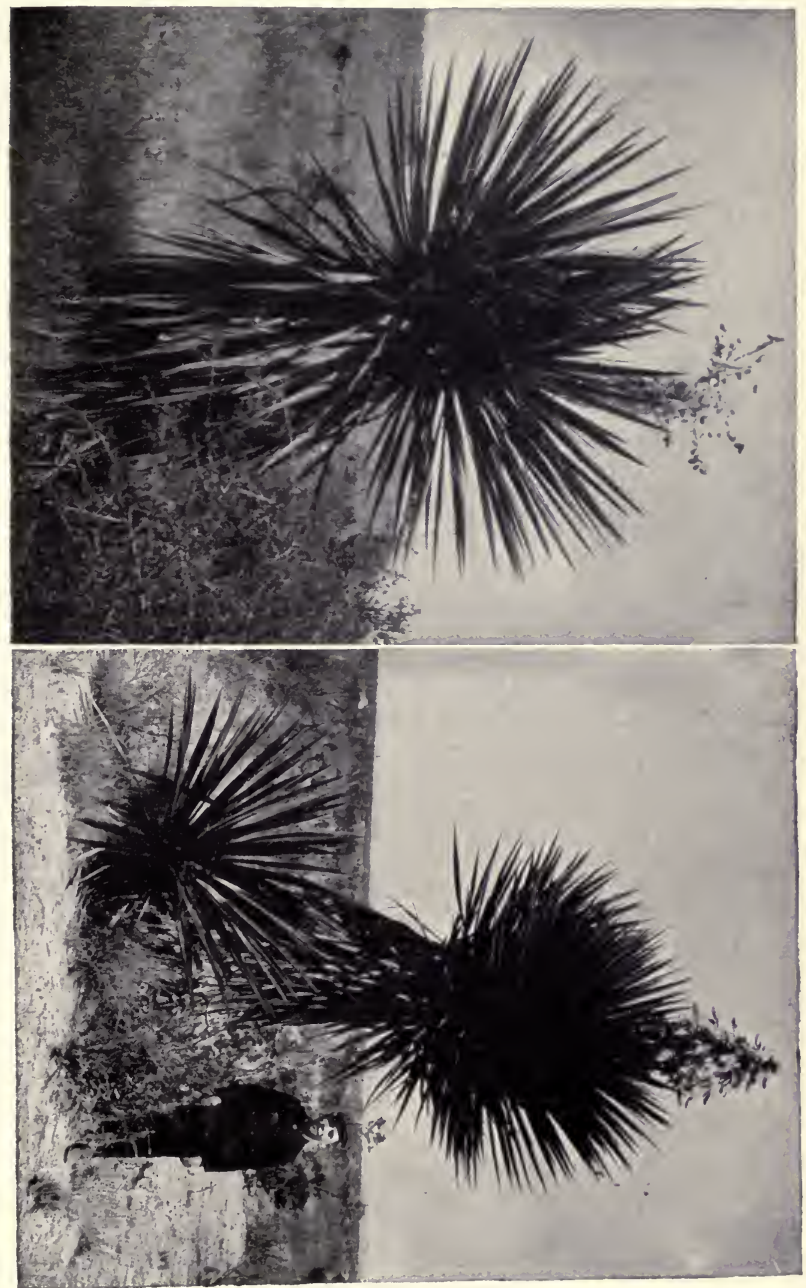



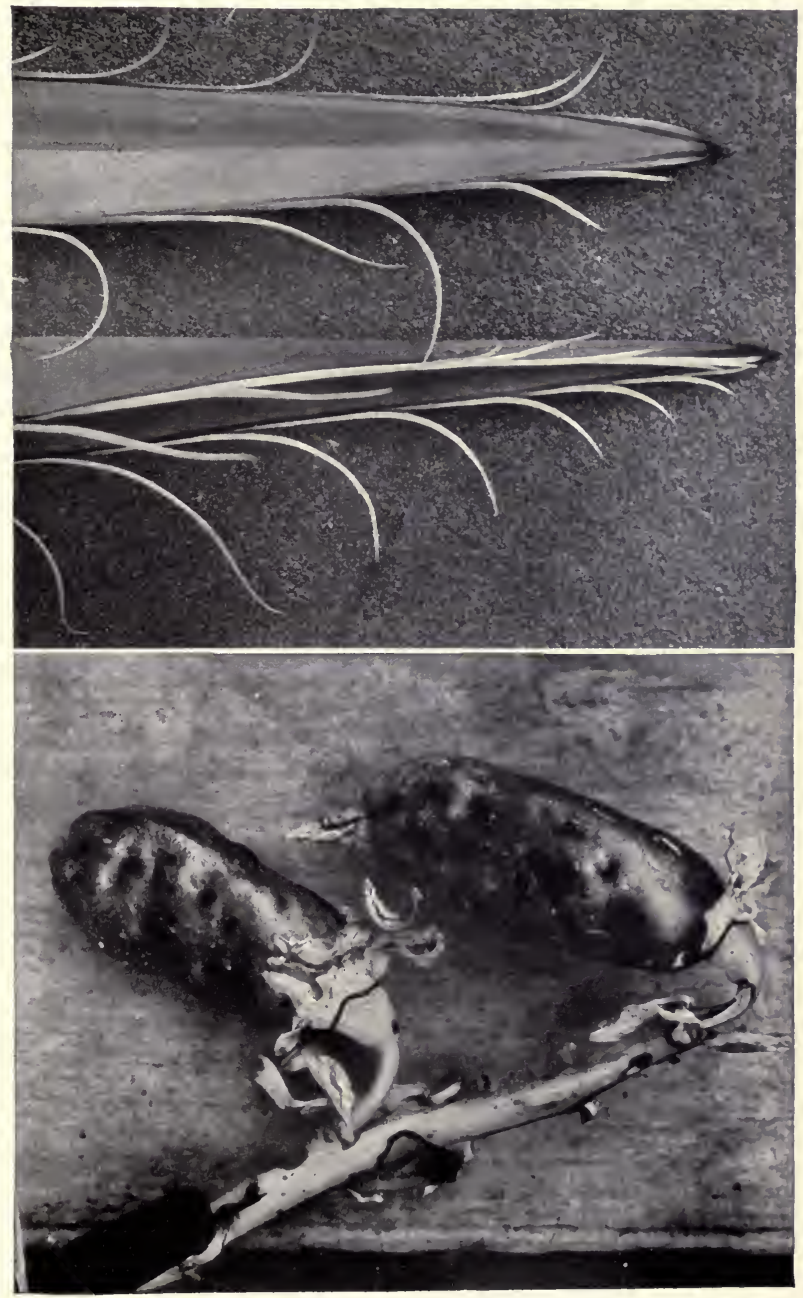


I 


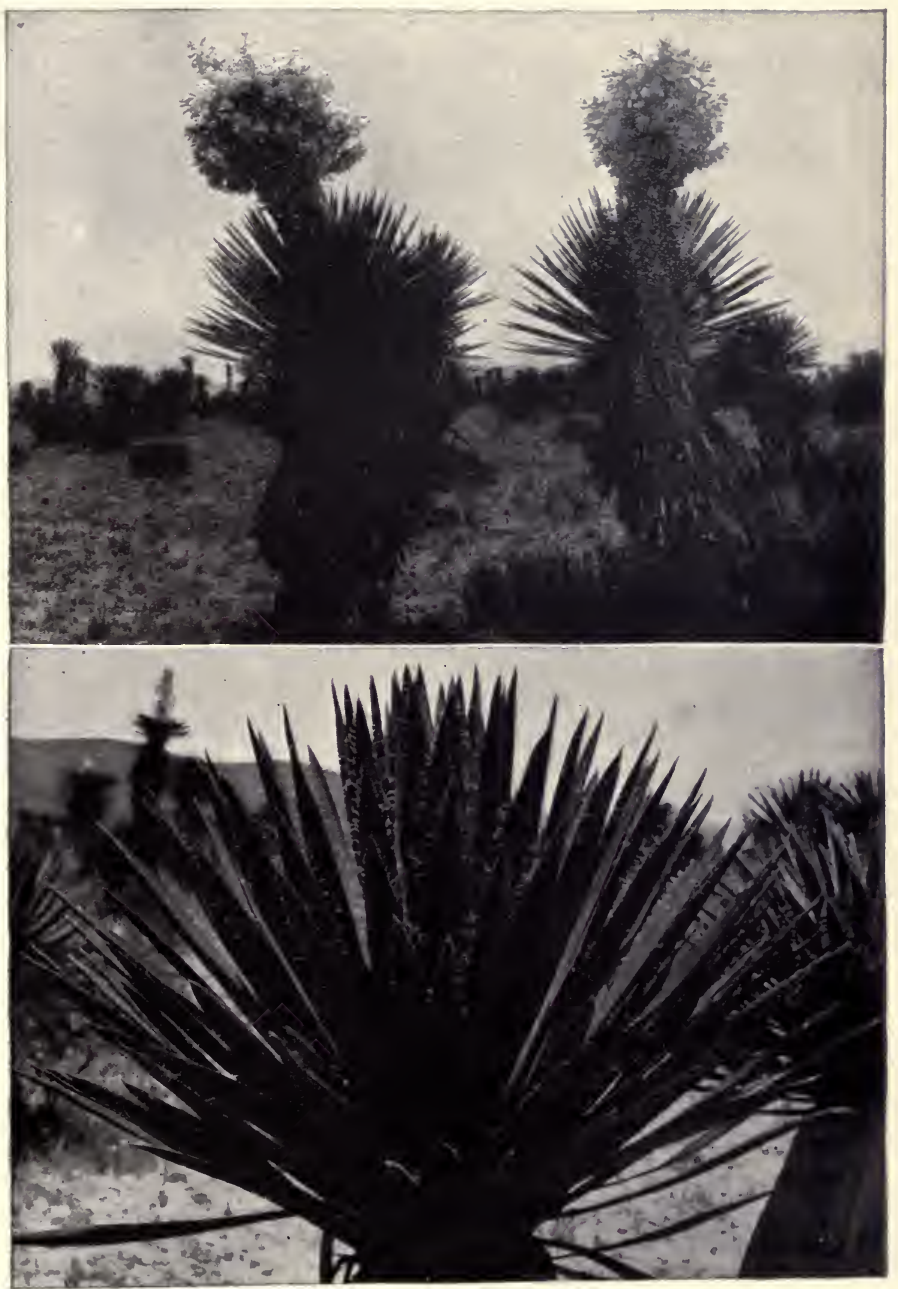





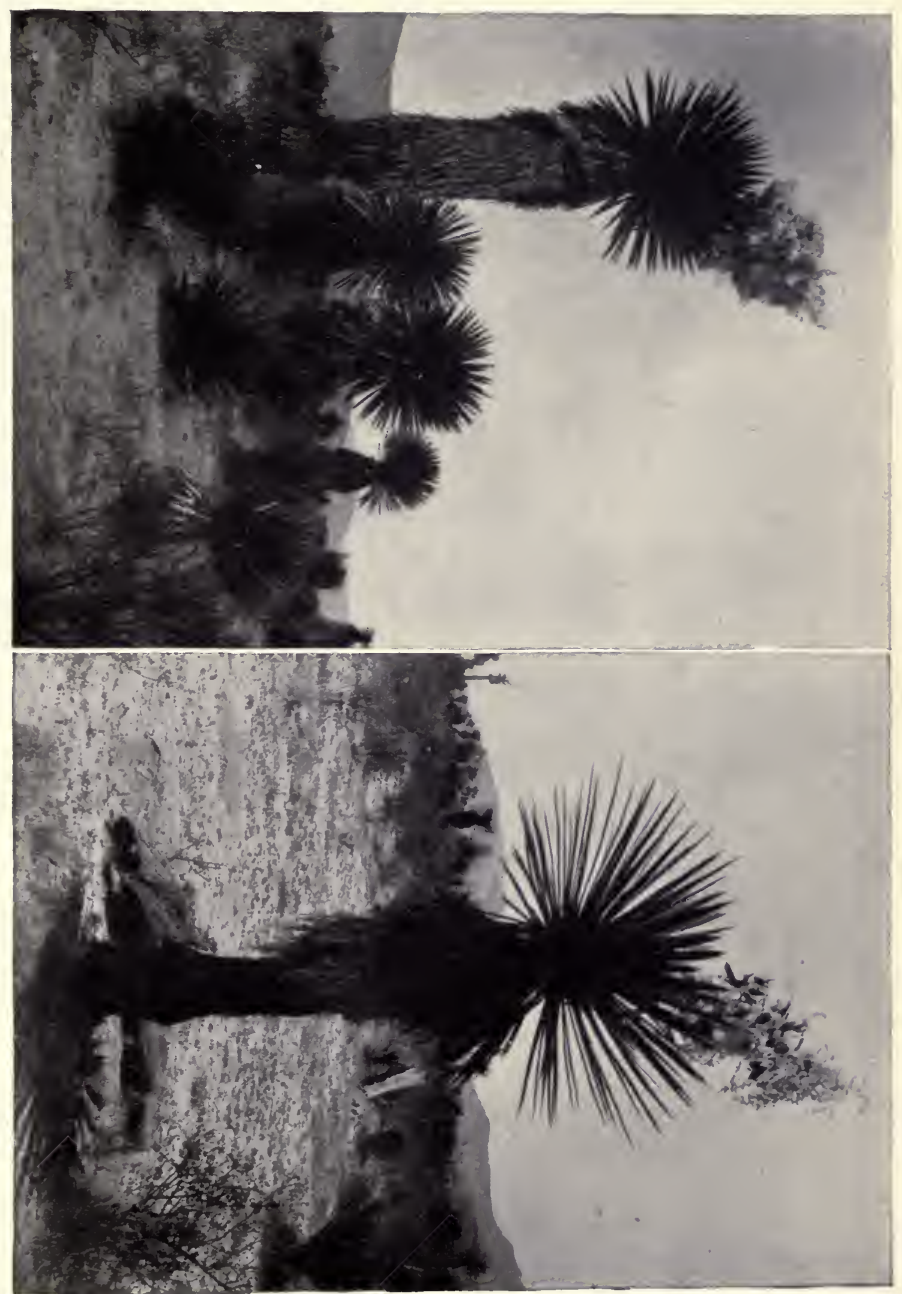




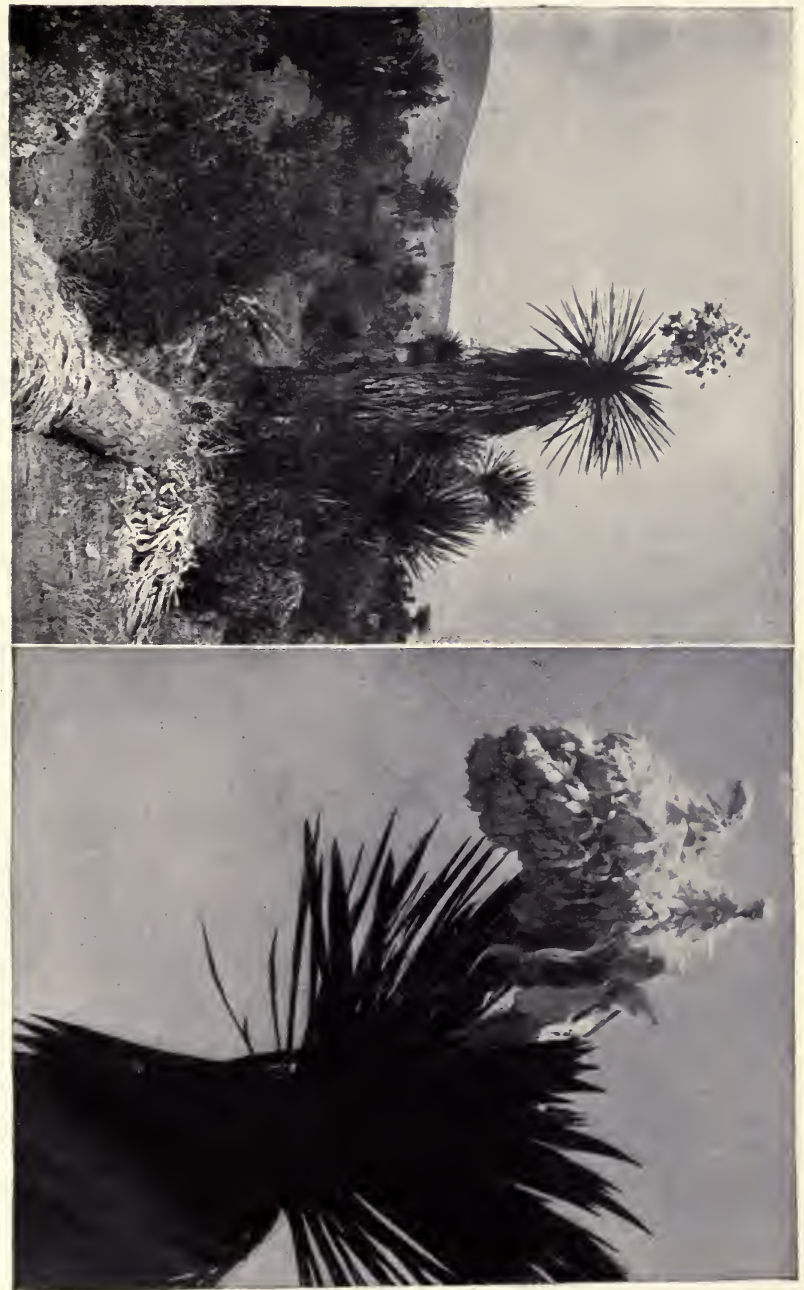


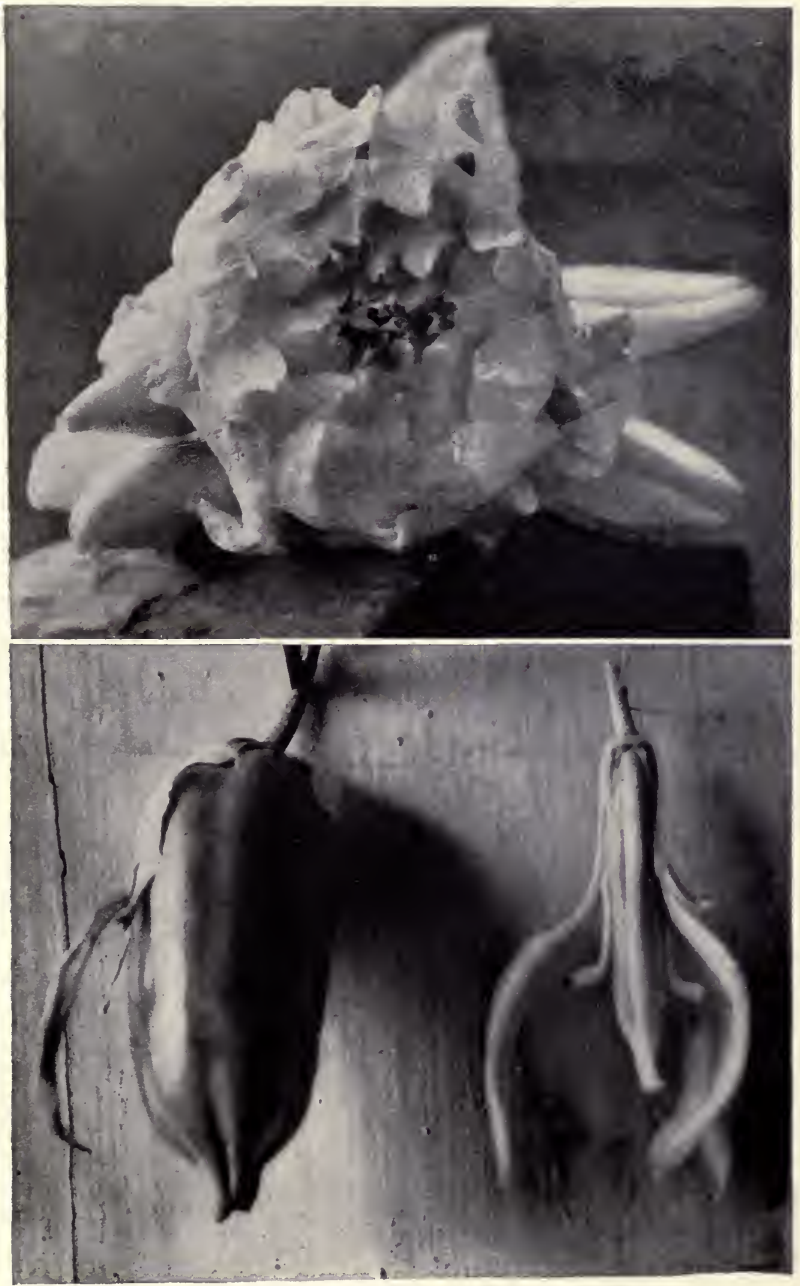

SAMUELA CARNEROSANA. 


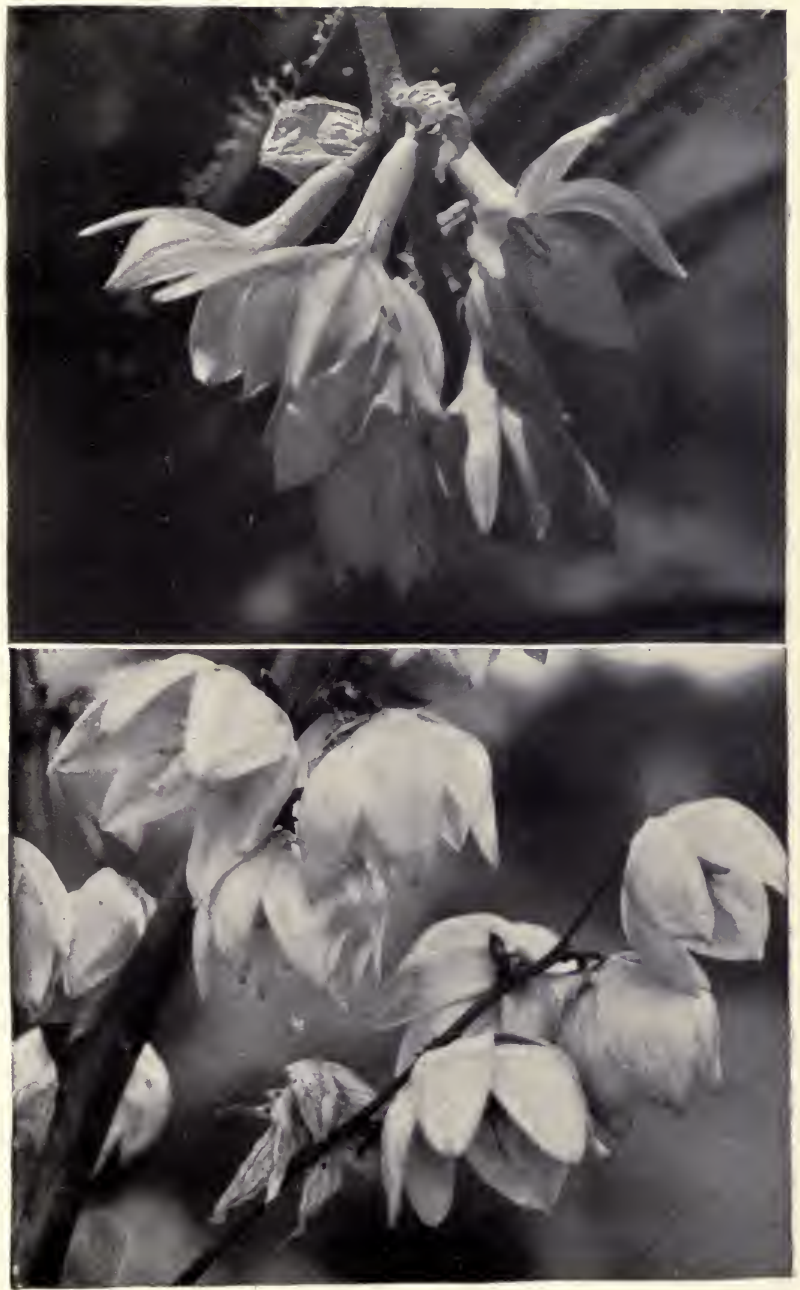

SAMUELA CARNEROSANA AND YUCCA FLACCIDA. 


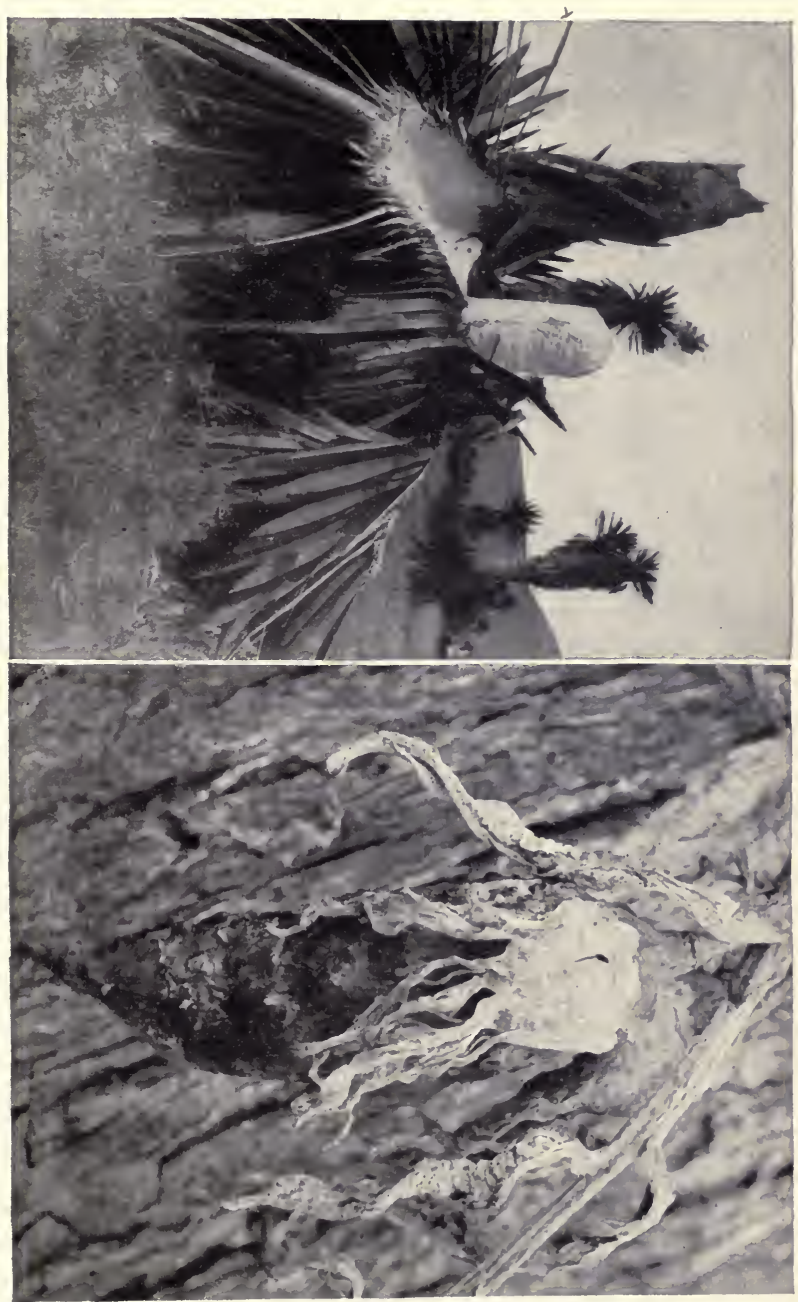



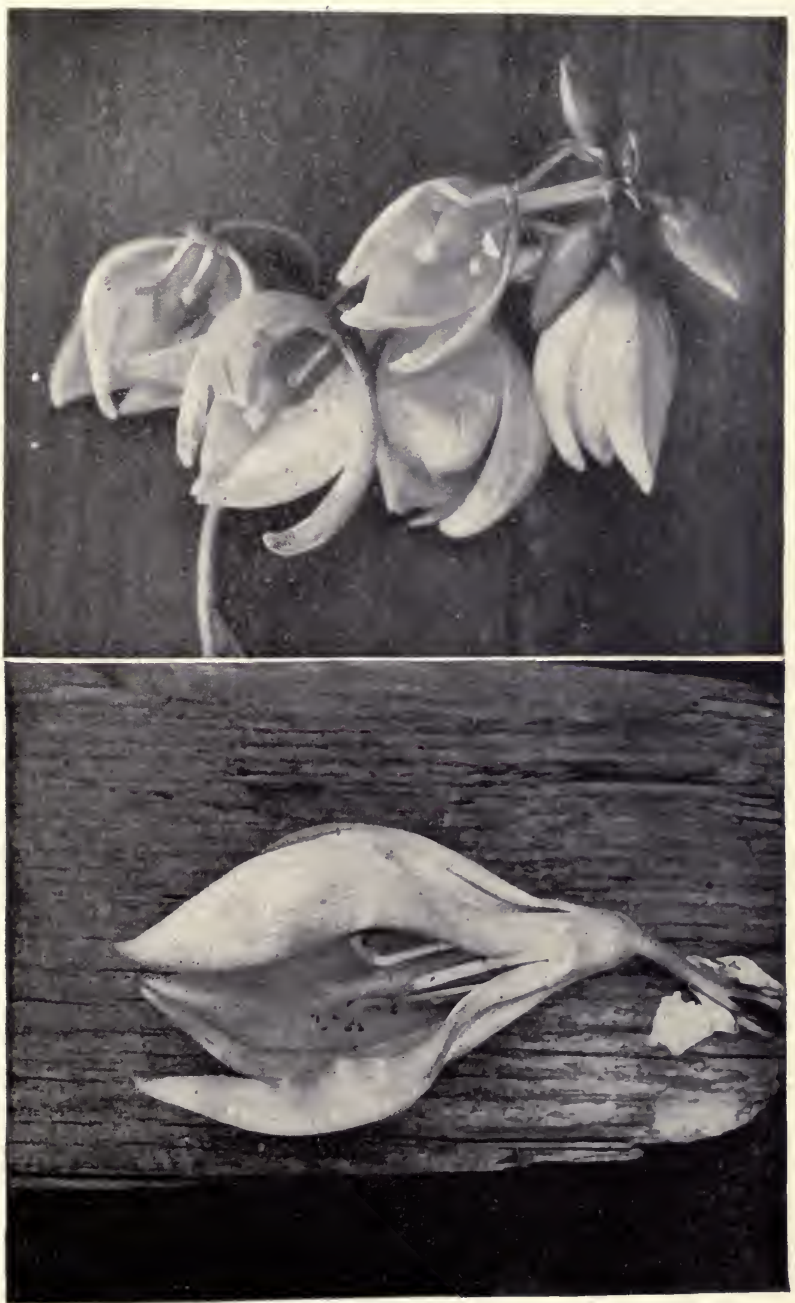





\section{- 00000 - 00000 \\ 000

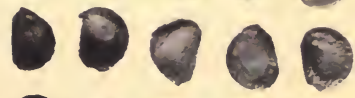 \\ 00000 \\ 0000}

000

0000

BDopo
-0000

- 000

- DODOO

DDOOO
(1)
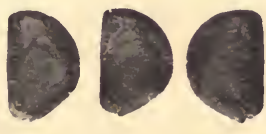

1000

00000

00000

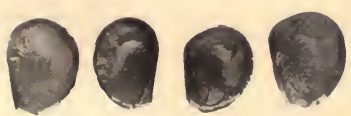

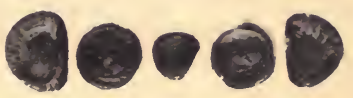

10000000 



\section{ODO000

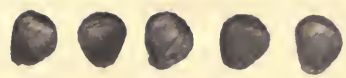 \\ - 0000 \\ - 0000

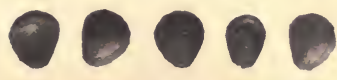 \\ 000000 \\ 0000}

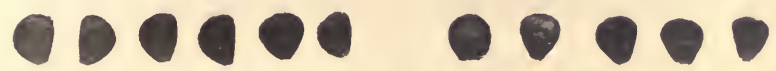

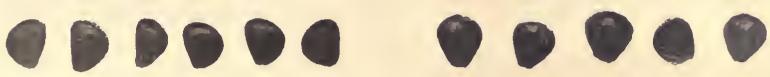

$\bullet \bullet \bullet \bullet \bullet \bullet \bullet ० \bullet$
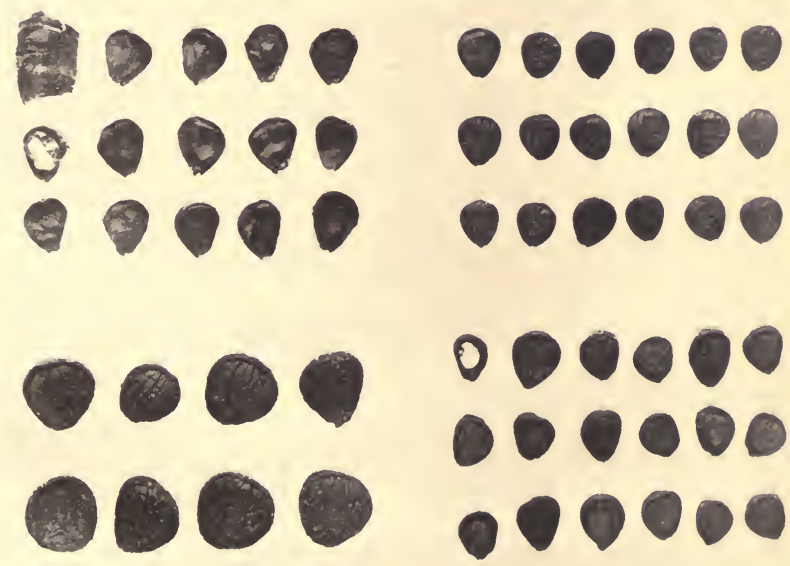


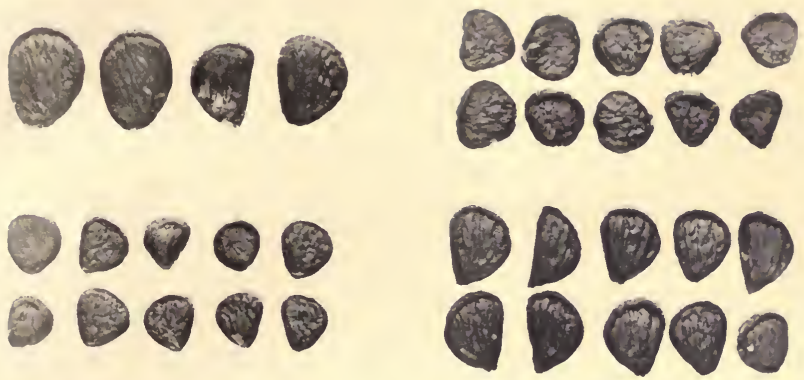

00000

00000

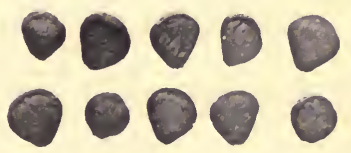

- ODDO
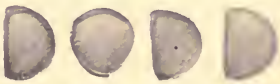

- 200
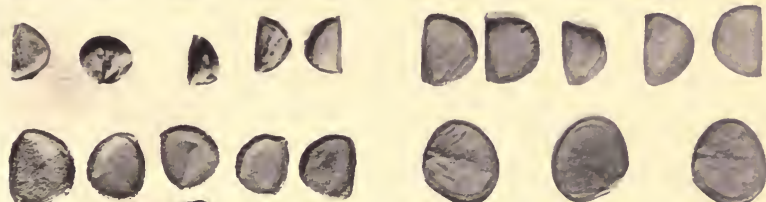

20
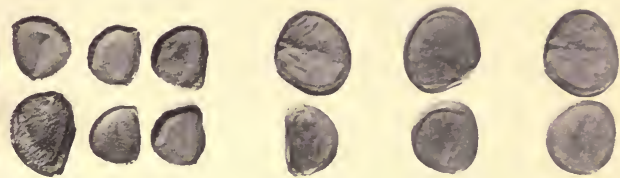

- 웡
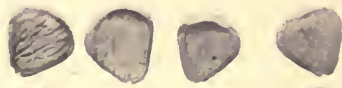

웅

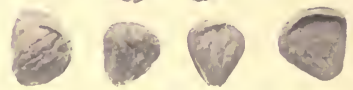





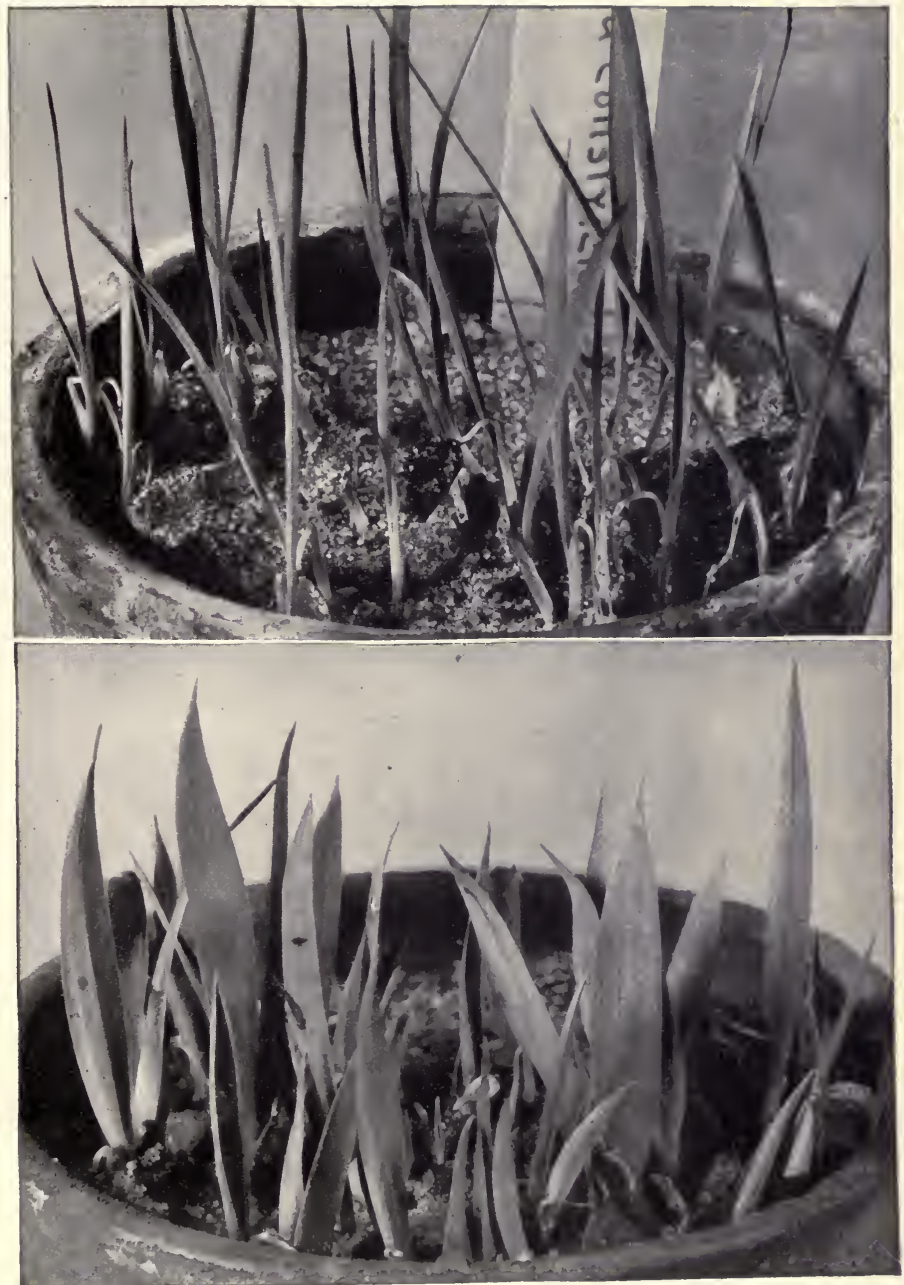




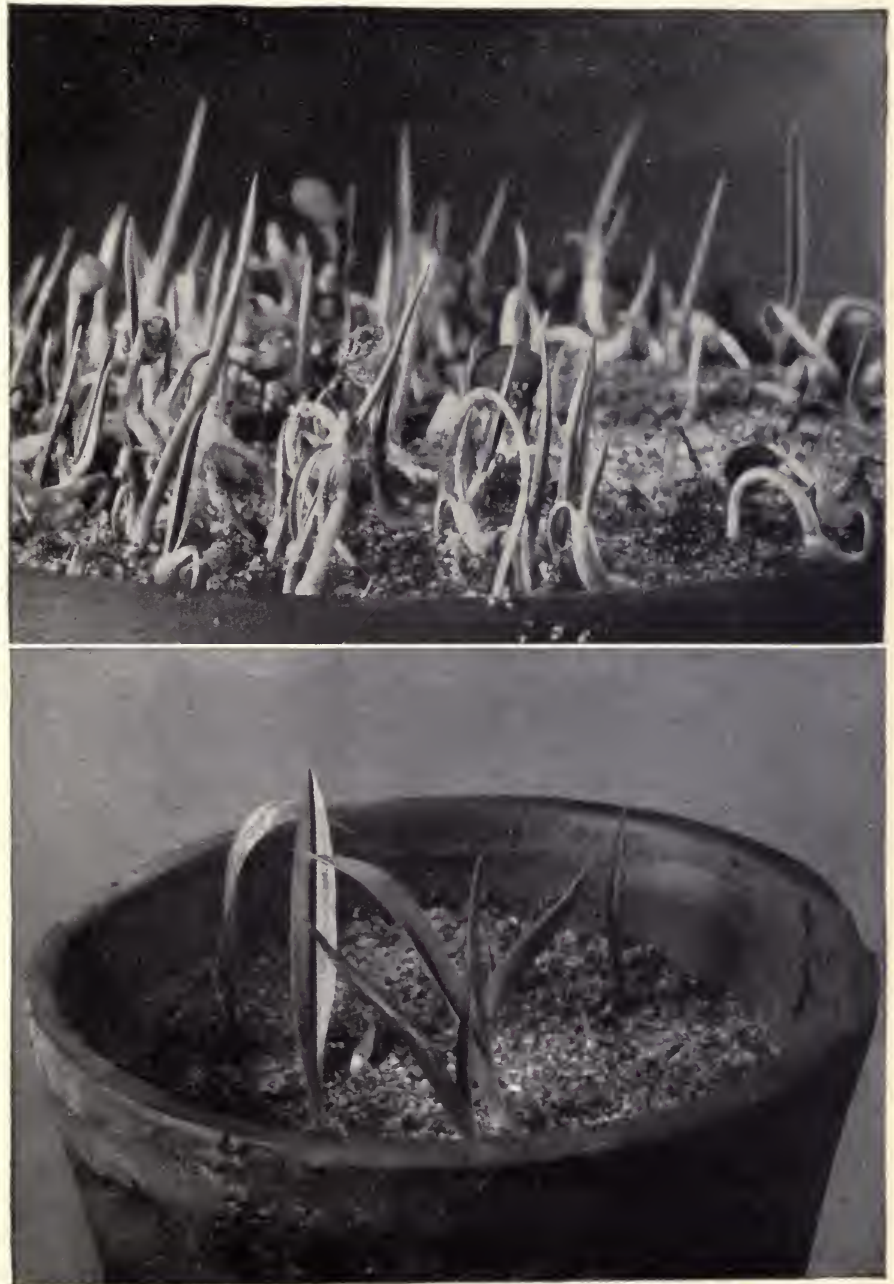



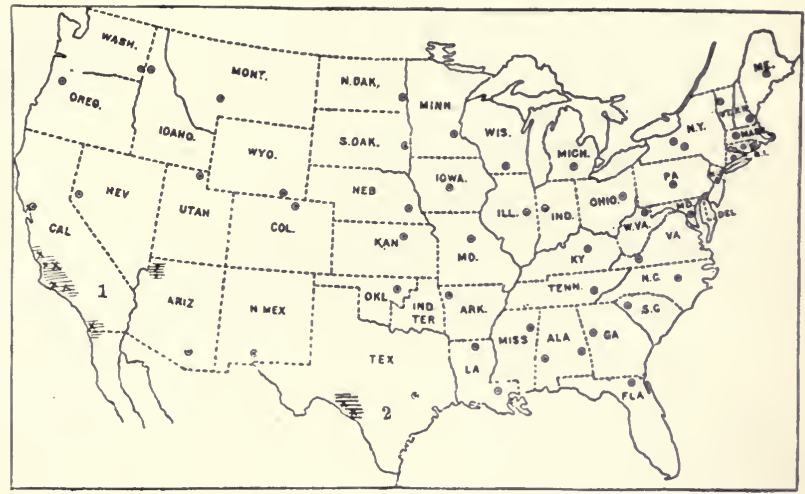

1. HESPEROYUCCA. 2. HESPERALOE PARVIFLORA.

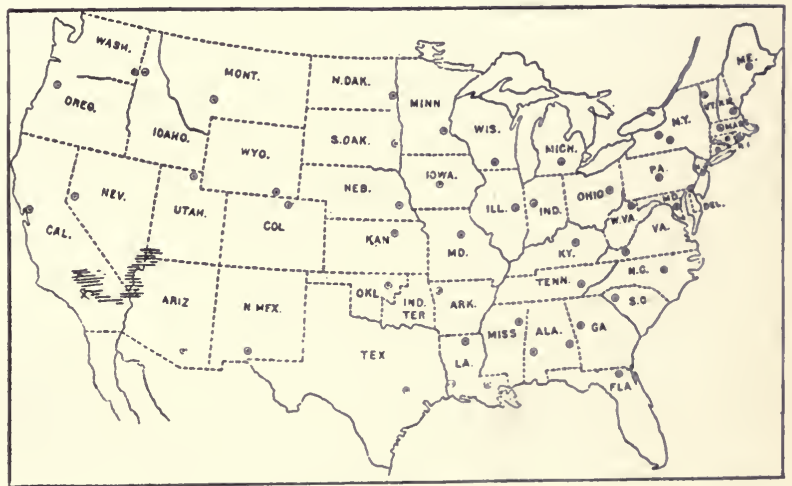

CLISTOYCCCA ARBORESCENS.

DISTRIBUTION OF YUCCEAE. 



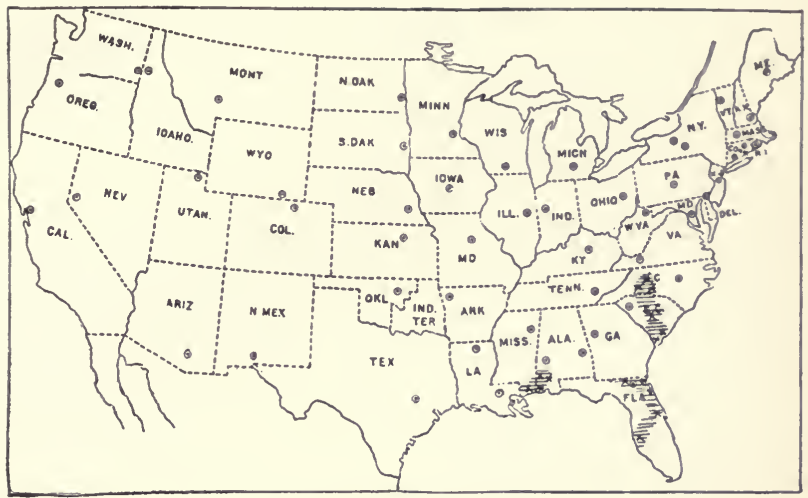

YUCCA FILAMENTOSA VERA,

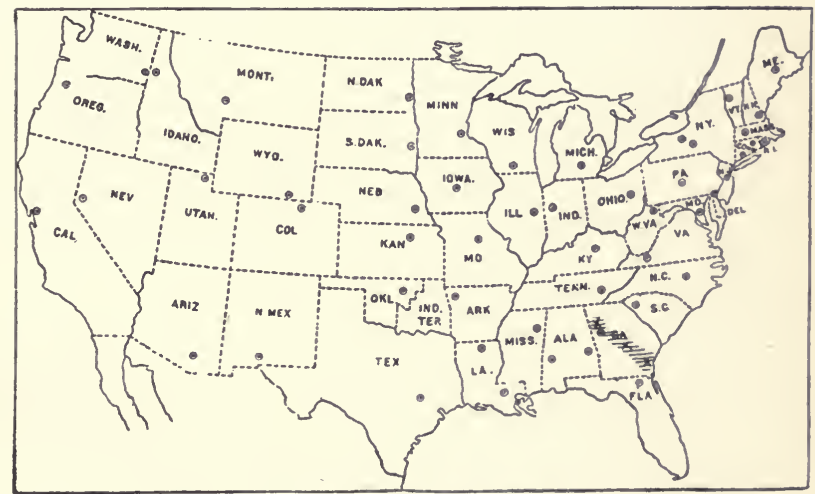

YUCCA FILA MENTOSA PATENS.

DISTRIBUTION OF YUCCEA E. 



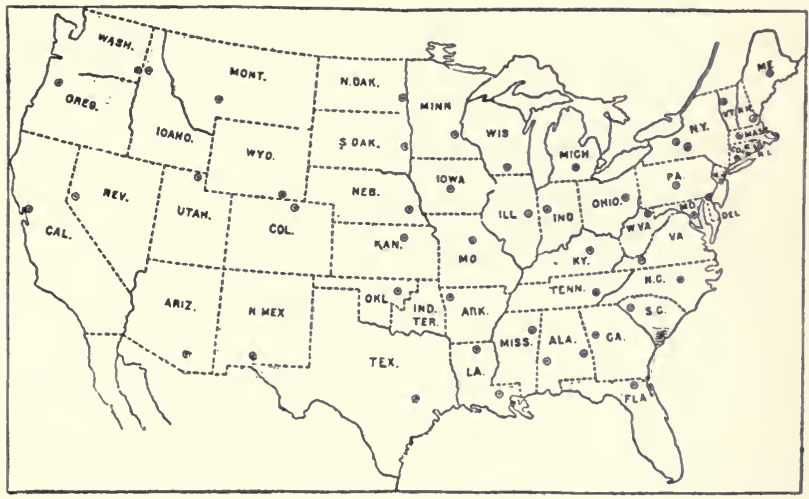

YUCCA FILAMENTOSA BRACTEATA.

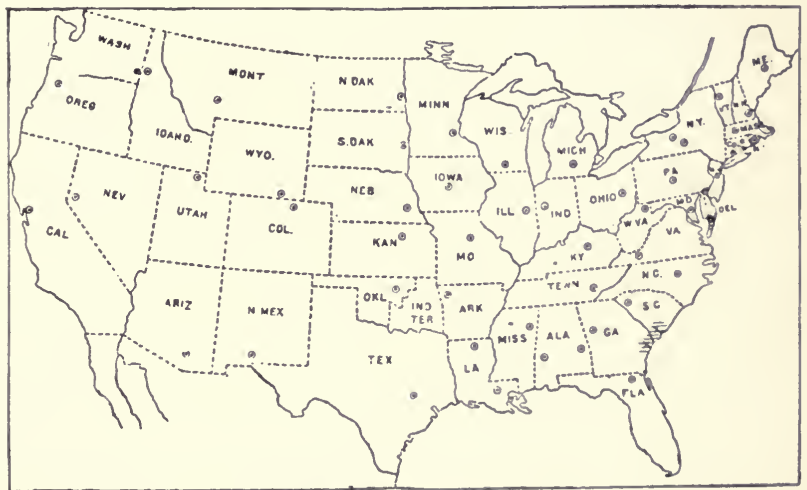

YUCCA FILAMENTOSA CONCAFA.

DISTRIBUTION OF YUCCEAE. 



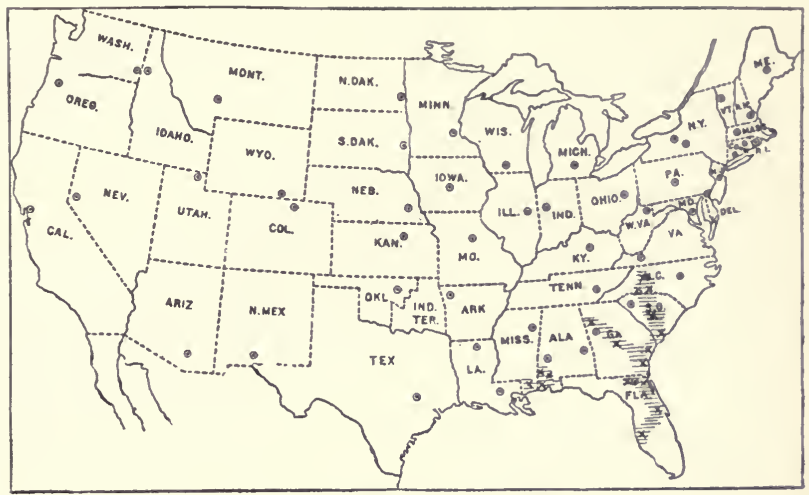

YUCCA FILAMENTOSA and varieties.

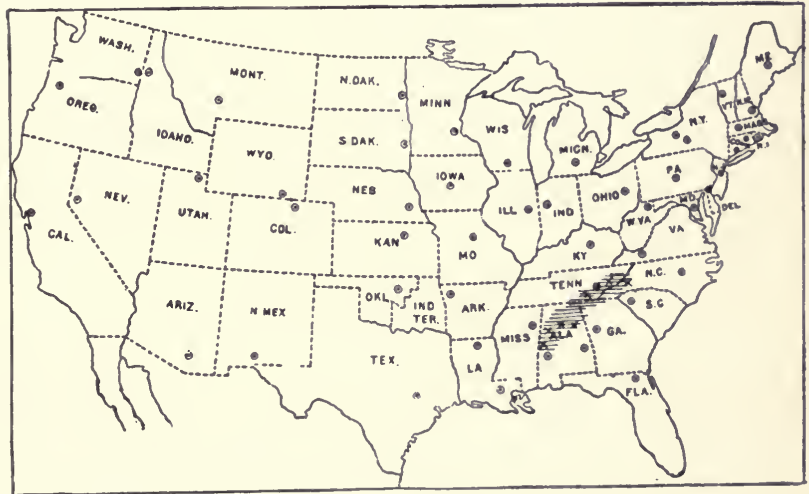

YUCCA FLACCIDA.

DISTRIBUTION OF YUCCEAE. 



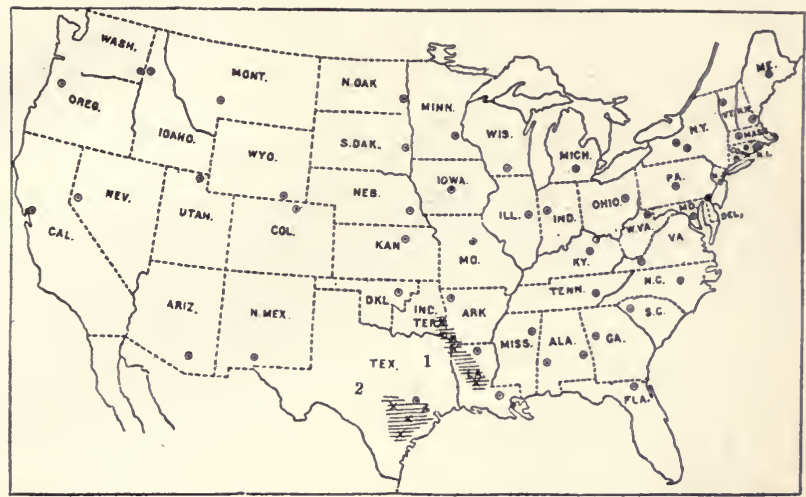

1. YUCCA LOUISIANENSIS, 2. Y. TENUISTYLA.

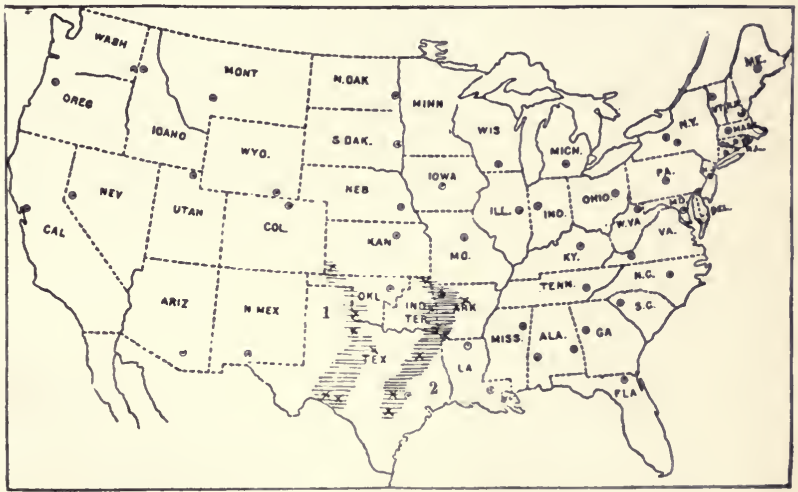

1. YUCCA CONSTRICTA. 2, Y. ARKANSANA. 



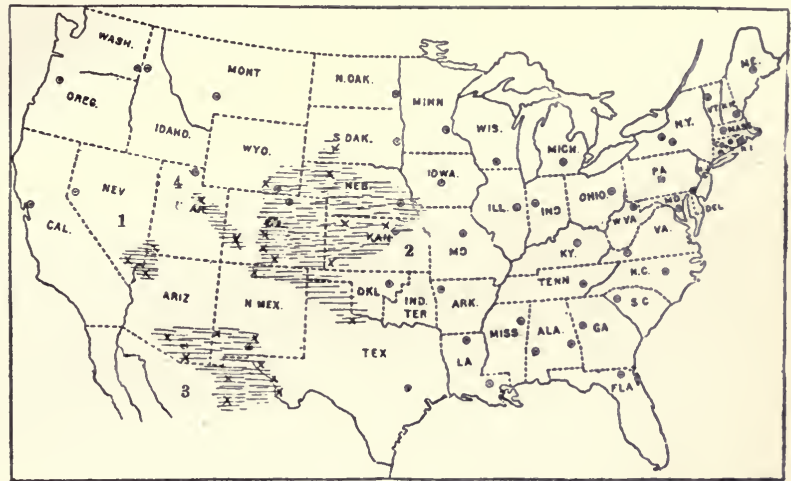

1. YUCCA ANgUStissima. 2. Y. GLAeCA. 3. Y. RAdiosa. 4. Y. Harmimasiak.

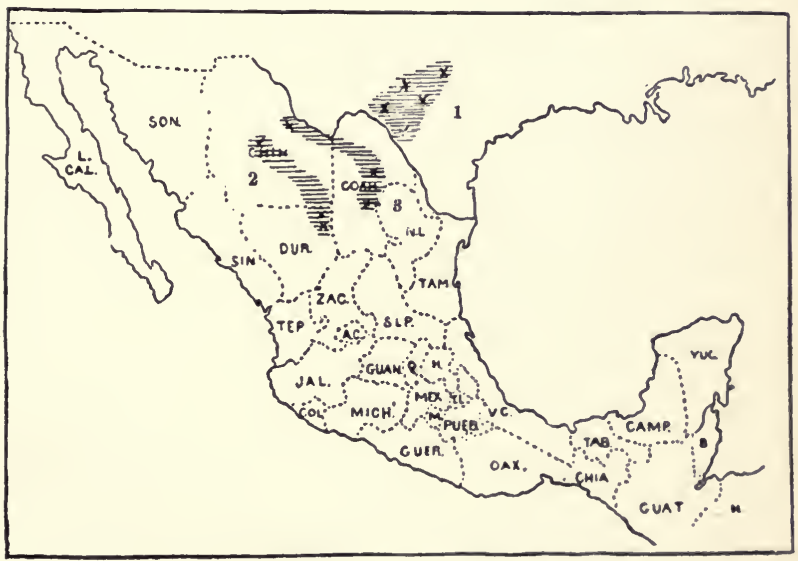

1. Y. RUPICOLA. 2. Y. RIGIDA. 3, Y. ROSTRATA. 



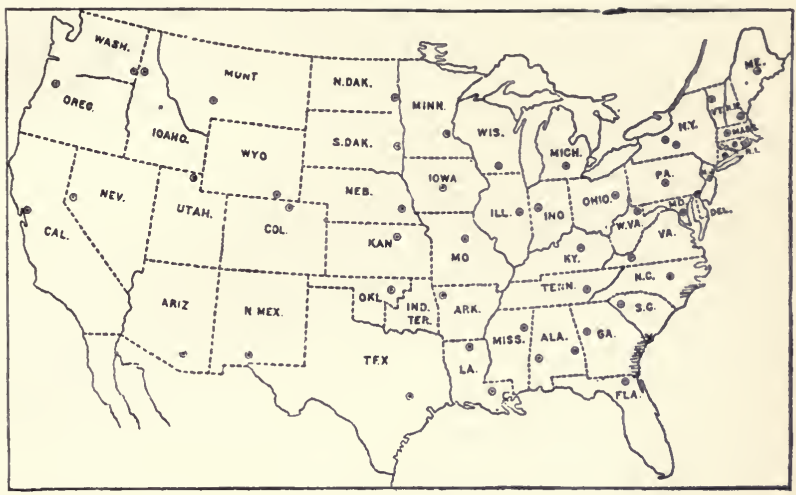

YUCCA GLORIOSA.

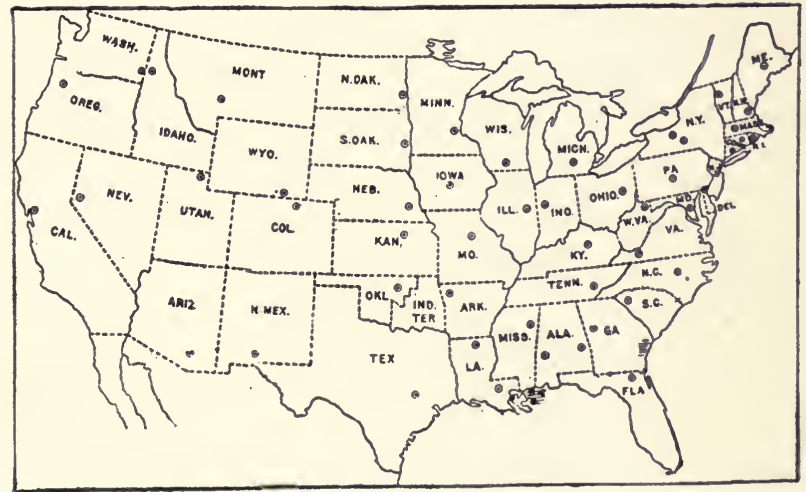

YUCCA RECURVIFOLIA.

DISTRIBUTION OF YUCCEAE. 


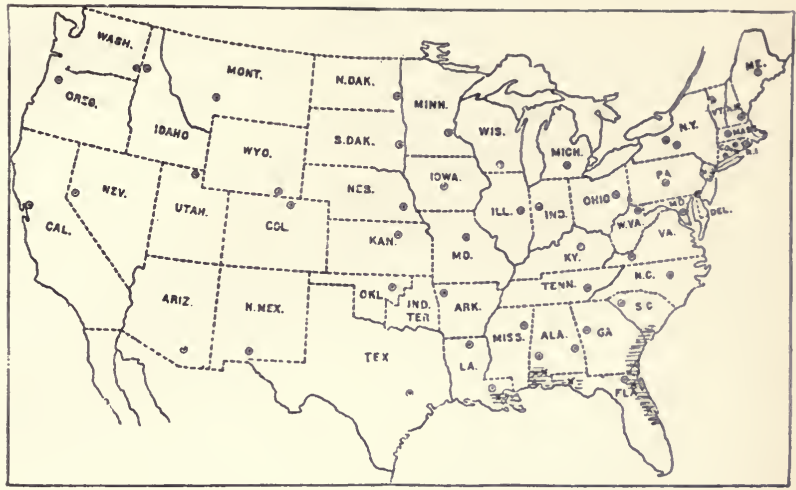

IUCCA ALOIFolis, in the United States.

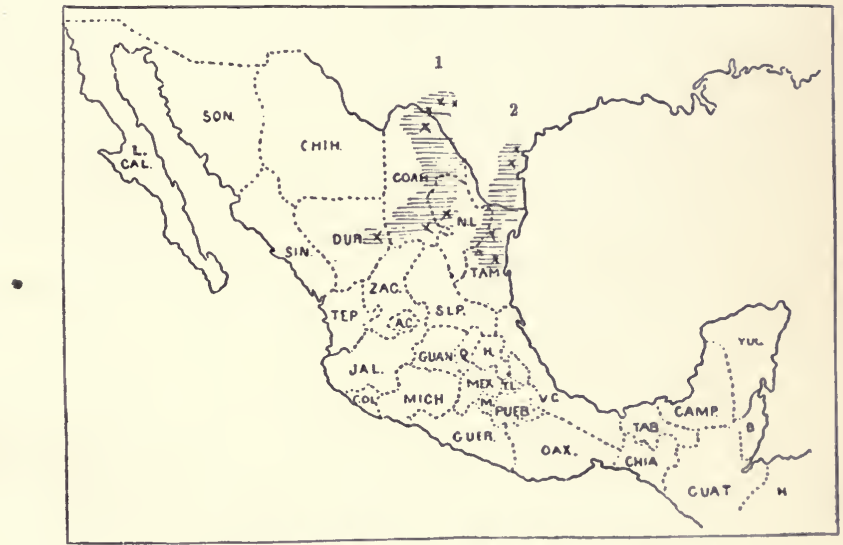

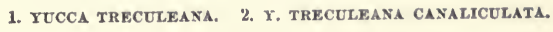





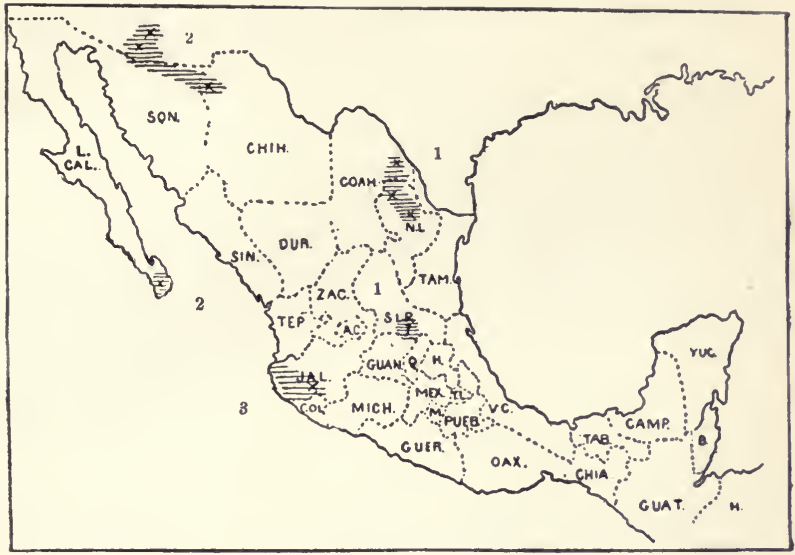

1. HESPERALOE FUNIFERA. 2. YUCCA SCHOTTII. 3. Y. SCHOTTI JALISCENSIS.

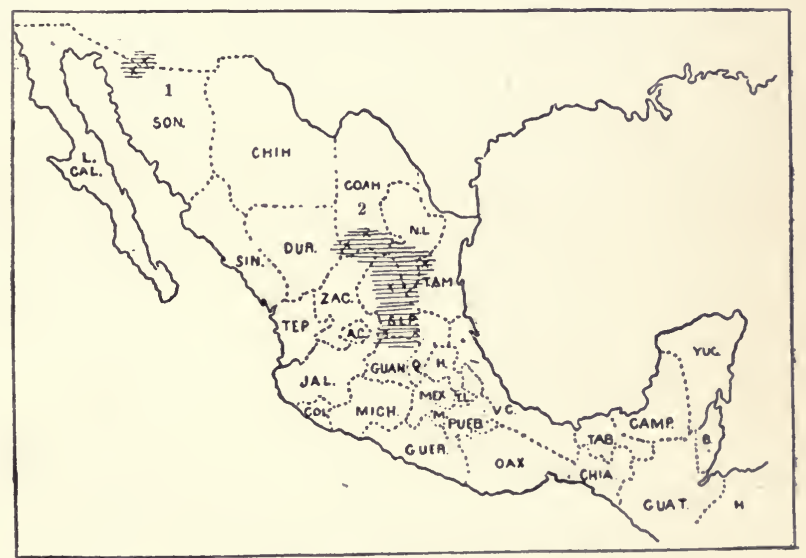

1. YUCCA BREVIFOLIA. 2. Y. AUSTRALIS. 



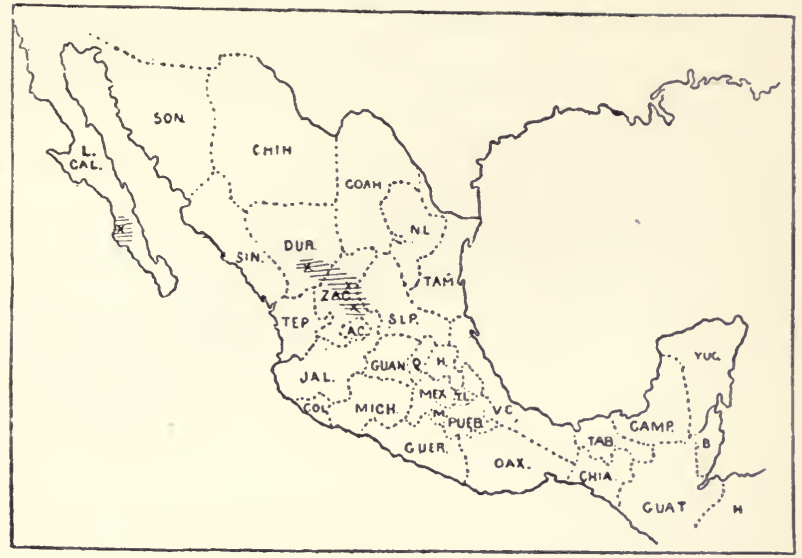

YUCCA VALIDA.

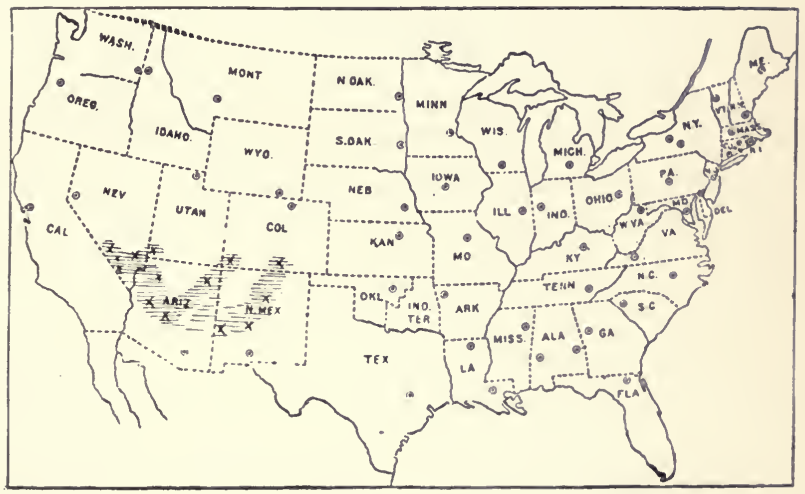

IUCCA BACCATA.

DISTRIBUTION OF YUCCEAE. 



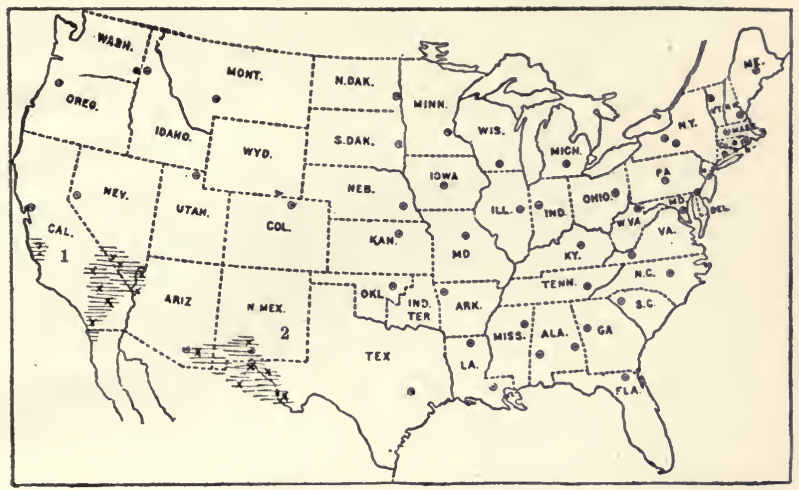

1. YUCCA MOHAVENSIS. 2. Y. MACRoCARPA.

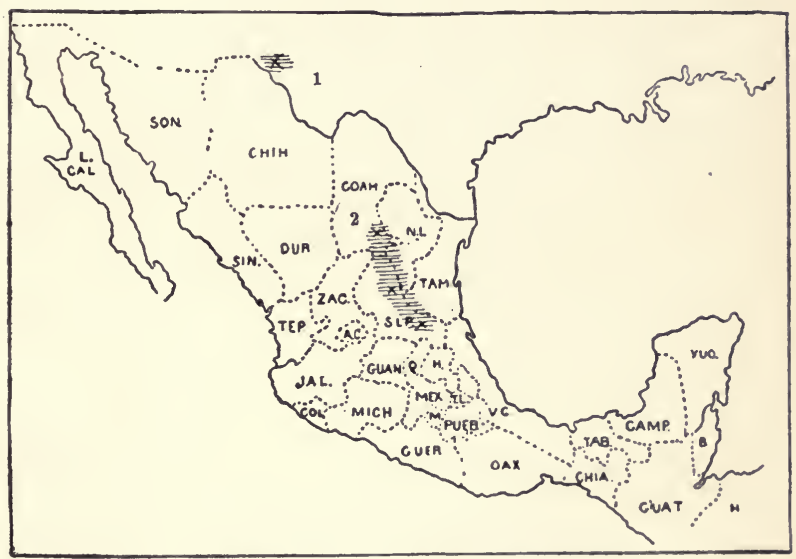

1. SAMUELA FAXoNiaNa. 2. S. CARNERosaNa. 


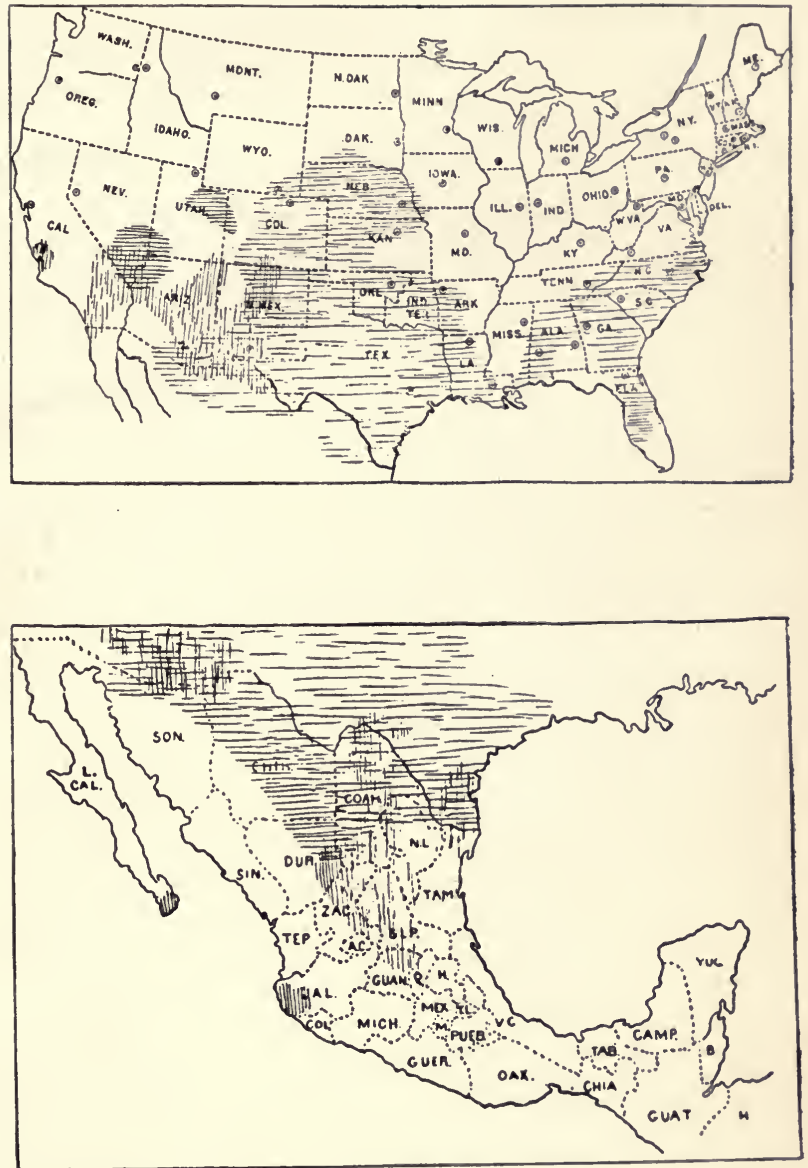

DISTRIBUTION OF YUCCA IN THE UNITED STATES AND MKXICO.

Horizontal shading indicates the range of capsular species, and vertical shading, of baccate species. 
- 

